\title{
A Bioinspired Trinuclear Copper Catalyst for Water Oxidation with a Turnover Frequency up to $20,000 \mathrm{~s}^{-1}$
}

Qi-Fa Chena, Ze-Yu Chengb, Rong-Zhen Liao*b, Ming-Tian Zhang*a

a Center of Basic Molecular Science (CBMS), Department of Chemistry, Tsinghua University, Beijing 100084, China.

${ }^{b}$ Key Laboratory of Material Chemistry for Energy Conversion and Storage, Ministry of Education, Huazhong University of Science and Technology, Wuhan 430074, China

${ }^{*} E$-mail: mtzhang@mail.tsinghua.edu.cn; rongzhen@hust.edu.cn 
Section 2: Synthesis of $\mathrm{H}_{2}$ app ligand and catalyst $\left[\left(\operatorname{app}^{2-}\right) \mathrm{Cu}_{3}(\mu-\mathrm{OH})\right]\left(\mathrm{CF}_{3} \mathrm{SO}_{3}\right)_{3}$ (TNC-Cu)

Figures S1 - 8

Section 3: Synthesis and characterization of $\mathrm{F}-\mathrm{N}_{2} \mathrm{O}_{2} \mathrm{Cu}$ and $\mathrm{HappCu}$. $\quad \mathrm{S} 16$ Figures S9 - 14

Section 4: Spectroscopic Characterization

Figures S15 - 16

Table S1

Section 5: Single-Crystal Structure

Figures S17 - 19

Tables S2 - 4

Section 6: Evidence for Homogeneous Catalysis

Figures S20 - 29

Section 7: Electrochemical Properties

Figures S30 - 44

Section 8: Catalytic performance comparison of the reported $\mathrm{Cu}$-based molecular catalysts for water oxidation

Table S5

Section 9: Computational details

Figures S45-52

Scheme S1 


\section{Section 1: Materials and Methods}

Materials: All chemicals used in this work, except the ligand $\left(\mathrm{H}_{2} \mathrm{app}\right)$ and the catalyst $\left(\left[\left(\operatorname{app}^{2-}\right) \mathrm{Cu}_{3}(\mu-\mathrm{OH})\right]\left(\mathrm{CF}_{3} \mathrm{SO}_{3}\right)_{3}\right) \quad(\mathrm{TNC}-\mathrm{Cu})$, were commercially available. The synthetic routes of $\mathrm{H}_{2}$ app ligand and $\left[\left(\operatorname{app}^{2-}\right) \mathrm{Cu}_{3}(\mu-\mathrm{OH})\right]\left(\mathrm{CF}_{3} \mathrm{SO}_{3}\right)_{3}$ are shown in Supplementary Fig. 1. Deionized water was further purified using a Milli-Q Ultrapure water purification system. Tetrabutylammonium hexafluorophosphate $\left(\mathrm{TBAPF}_{6}\right)$ was recrystallized from absolute ethanol and dried under vacuum. The $\mathrm{pH}$ of $1 \mathrm{M}$ and 0.1 $\mathrm{M} \mathrm{NaHCO} 3$ solutions was adjusted using solid $\mathrm{NaOH}$ or $\mathrm{CO}_{2}$. Fresh lithium diisopropylamide (LDA) in THF solution was synthesized by reacting $n$-butyllithium with diisopropylamine at $-78{ }^{\circ} \mathrm{C}$ and its concentration was determined by 2,2-diphenylacetic acid titration.

Instrumentation: NMR spectra were recorded on a Bruker Avance III HD 400 spectrometer $\left({ }^{1} \mathrm{H}\right.$ at $400 \mathrm{MHz},{ }^{13} \mathrm{C}$ at $\left.100 \mathrm{MHz}\right)$; ESI-HRMS spectra were measured on LCMS-IT/TOF instruments (Shimadzu and Thermo U3000+); FESEM images and energy dispersive X-ray spectroscopy (EDX) were obtained on a Hitachi SU-8000 field emission gun scanning electron microscope. X-ray photoelectron spectroscopy (XPS) analyses were carried out on a PHI Quantera SXM photoelectron spectrometer (ULVAC-PHI, Japan). UV-vis spectra were recorded in aqueous $\mathrm{NaHCO}_{3}(1 \mathrm{M}, \mathrm{pH}$ 8.4) by Agilent Cary 8454 spectrophotometer. The $\mathrm{pH}$ value of the $\mathrm{NaHCO}_{3}$ solution was measured using a Mettler Toledo S210 pH meter.

Electrochemistry Experiments: All the electrochemical experiments were conducted with a three-electrode system using a CHI-630 electrochemical workstation. Boron-doped diamond (BDD, $0.07 \mathrm{~cm}^{2}$ ) was used as the working electrode, the counter electrode was Pt wire, and a saturated calomel electrode $\left(\mathrm{Hg} / \mathrm{HgCl}_{2}, \mathrm{KCl}\right.$ saturated) was used as the reference electrode in aqueous solution, whereas $\mathrm{Ag} / \mathrm{AgNO}_{3}\left(0.1 \mathrm{M} \mathrm{AgNO}_{3}\right.$ in $\left.\mathrm{MeCN}\right)$ was used as the reference electrode in organic solution. The BDD electrode was polished with 0.3 and $0.05 \mu \mathrm{m}$ alumina $\left(\mathrm{Al}_{2} \mathrm{O}_{3}\right)$, washed with deionized water and then cleaned by scanning multiple cyclic voltammograms ranging from 0 to $2.24 \mathrm{~V}$ (vs NHE) in the blank solution $(0.1 \mathrm{M}$ phosphate buffer solution, $\mathrm{pH}$ 7) before use. In addition, fluorine-doped tin oxide (FTO, $\left.1 \mathrm{~cm}^{2}\right)$ and BDD plate electrode $\left(0.5 \mathrm{~cm}^{2}\right)$ were used as the working electrodes for bulky electrolysis. The electrochemical measurement in anhydrous $\mathrm{MeCN}$ was performed in a glovebox with argon atmosphere. Cyclic voltammetry $(\mathrm{CV})$ in aqueous $\mathrm{NaHCO}_{3}(1 \mathrm{M})$ was performed at room temperature, and the potential values are reported versus the normal hydrogen electrode (NHE), unless otherwise specified.

Oxygen Evolution: A calibrated Ocean Optics FOXY probe was used for monitoring the dissolved oxygen during controlled potential electrolysis (CPE). CPE was conducted with $\left[\left(\operatorname{app}^{2-}\right) \mathrm{Cu}_{3}(\mu-\mathrm{OH})\right]\left(\mathrm{CF}_{3} \mathrm{SO}_{3}\right)_{3} \quad(1 \mathrm{mM})$ in a sealed standard three-electrode cell containing aqueous $\mathrm{NaHCO}_{3}(1 \mathrm{M}, \mathrm{pH}$ 8.4) with stirring. FTO electrode $\left(1 \mathrm{~cm}^{2}\right)$ and BDD plate electrode $\left(0.5 \mathrm{~cm}^{2}\right)$ were used as working electrodes, 
a Pt wire was used as the counter electrode and the reference electrode was $\mathrm{Ag} / \mathrm{AgCl}$. During CPE, the applied potential was set at $1.64 \mathrm{~V}$ or $2.14 \mathrm{~V}$ (vs NHE). The used electrodes (FTO or BDD) after electrolysis were further analysed by UV-vis spectroscopy, SEM, EDX, XPS and other controlled experiments (the details were listed in supplementary Figs. 20-29).

The Faradaic efficiency of TNC-Cu was calculated according to the following equation.

$$
\text { Faradic efficiency }=\frac{\text { moles of } \mathrm{O}_{2} \text { experimental }}{\text { moles of } \mathrm{O}_{2} \text { charge }} \times 100 \%
$$

The moles of $\mathrm{O}_{2}$ experimental represents the total amount of evolved $\mathrm{O}_{2}$ includes the dissolved $\mathrm{O}_{2}$ in catalyst solution and the percentage of $\mathrm{O}_{2}$ in the headspace of the electrochemical cell. The moles of $\mathrm{O}_{2}$ charge represents the theoretical value of evolved $\mathrm{O}_{2}$ (four-electron oxidation process) determined according to total charge $\mathrm{Q}$ passed during $\mathrm{CPE}$ at $1.64 \mathrm{~V}$. The moles of $\mathrm{O}_{2}$ charge $(\mathrm{n})=\mathrm{Q} / 4 \mathrm{~F}, \mathrm{~F}$ is the Faraday constant.

Foot of the Wave Analysis: Foot of the Wave Analysis was a method proposed by Savéant $e t a l^{1}$ to evaluate the catalytic activity (turnover frequency, TOF) of a potential catalyst, especially for reduction reactions such as $\mathrm{CO}_{2}$ reduction. Recently, Foot of the Wave Analysis was applied to evaluate the catalytic activity of water oxidation catalysts ${ }^{2,3}$. The equation was shown as follows.

$$
\frac{i_{\mathrm{cat}}}{i_{\mathrm{d}}}=\frac{8.97 \sqrt{\left(\frac{R T}{F v}\right) k_{o b s}}}{1+\exp \left(\frac{F\left(E-E^{0}\right)}{R T}\right)}
$$

where $i_{\text {cat }}$ is the catalytic current in presence substrate (here $\mathrm{H}_{2} \mathrm{O}$ as the substrate), $i_{\mathrm{d}}$ is the diffusion current without substrate (here the current of the oxidative wave of $\mathrm{Cu}^{\mathrm{III}} \mathrm{Cu}^{\mathrm{II}} / \mathrm{Cu}^{\mathrm{II}}{ }_{3}$ at $\sim 1.2 \mathrm{~V}$ vs NHE is used as $i_{\mathrm{d}}$ as an approximation), $R$ is the universal gas constant, $T$ is the absolute temperature. $F$ is the Faraday constant, $v$ is the scanning rate, $k_{\mathrm{obs}}$, which is also known as the turnover frequency (TOF), is the catalytic rate of the catalyst, $E^{0}$ is the potential for the initial-catalysis couple of oxidative couple (here $\sim 1.6 \mathrm{~V}$ determined from DPV), $E$ is the applied potential. Plotting $i_{\text {cat }} / i_{\mathrm{d}}$ vs $1 /\left(1+\exp \left[(\mathrm{F} / \mathrm{RT})\left(E-E^{0}\right)\right]\right)$ and a straight line could be obtained, where the $k_{\text {obs }}$ could be calculated according to this line's slope. TOF 0 is the TOF at zero overpotential, which represents the intrinsic turnover frequency of the catalyst ${ }^{1}$.

1 Costentin, C., Drouet, S., Robert, M. \& Saveant, J. M. Turnover numbers, turnover frequencies, and overpotential in molecular catalysis of electrochemical reactions. Cyclic voltammetry and preparative-scale electrolysis. J. Am. Chem. Soc. 134, 11235-11242 (2012).

2 Matheu, R. et al. Intramolecular proton transfer boosts water oxidation catalyzed by a $\mathrm{Ru}$ complex. J. Am. Chem. Soc. 137, 10786-10795 (2015).

3 Creus, J. et al. A million turnover molecular anode for catalytic water oxidation. Angew. Chem. Int. Ed. 55, 15382-15386 (2016). 
Section 2: Synthesis of $\mathrm{H}_{2}$ app ligand and catalyst $\left[\left(\operatorname{app}^{2-}\right) \mathrm{Cu}_{3}(\mu-\mathrm{OH})\right]\left(\mathrm{CF}_{3} \mathrm{SO}_{3}\right)_{3}$ (TNC-Cu)
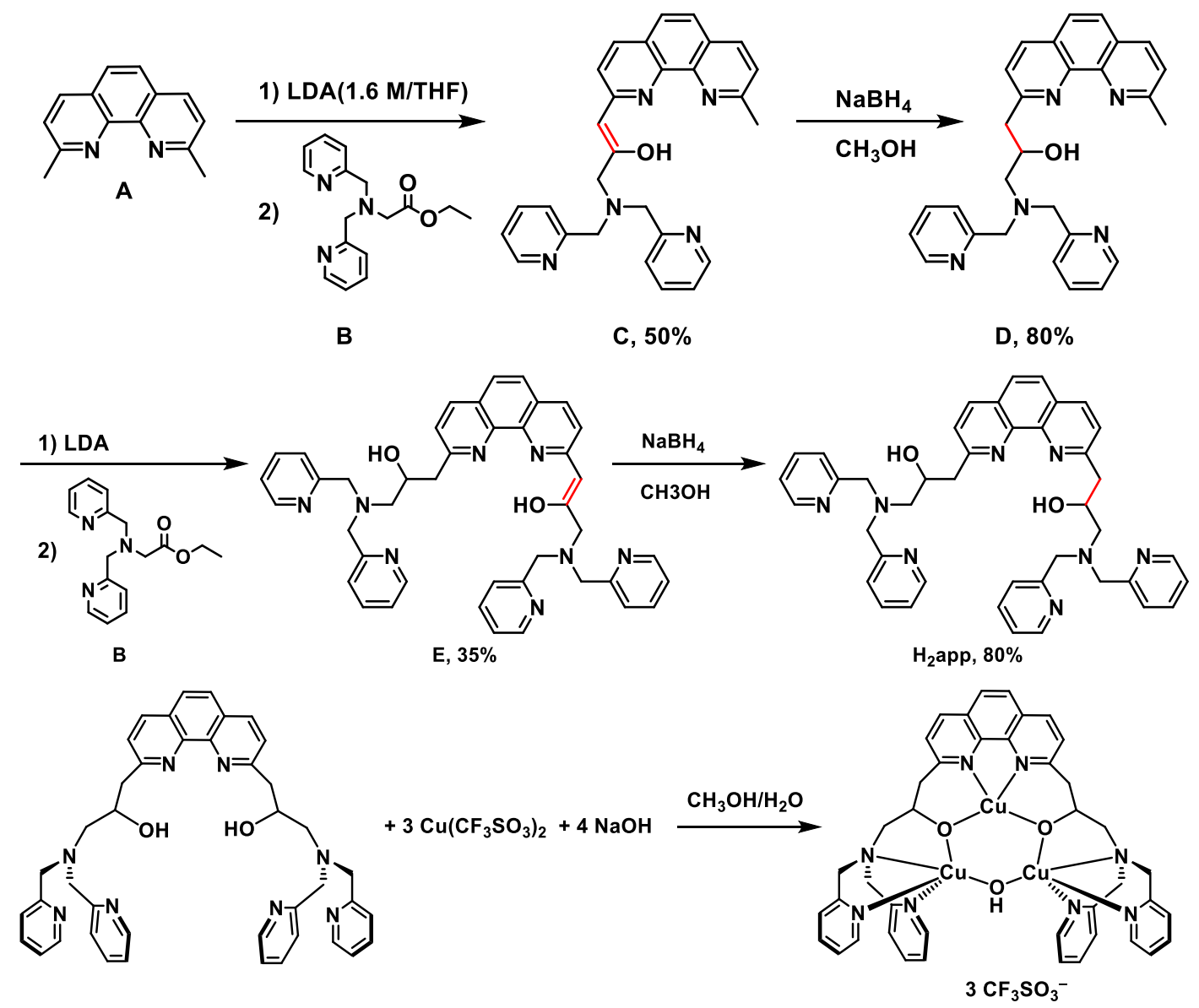

$\mathrm{H}_{2}$ app

$\left[\left(\mathrm{app}^{2-}\right) \mathrm{Cu}_{3}(\mu-\mathrm{OH})\right]\left(\mathrm{CF}_{3} \mathrm{SO}_{3}\right)_{3}(\mathrm{TNC}-\mathrm{Cu})$

Figure S1 | Synthesis of the ligand $\mathrm{H}_{2}$ app and catalyst TNC-Cu.

\subsection{Synthesis of $\mathbf{C}$}

To solution of 2,9-dimethyl-1,10-phenanthroline $\mathbf{A}(2 \mathrm{~g}, 9.6 \mathrm{mmol})$ in anhydrous THF ( $25 \mathrm{~mL}$ ) was added dropwise over $50 \mathrm{~min}$ fresh LDA (1.6 M solution in THF, 15 $\mathrm{mL}, 24 \mathrm{mmol})$ under an argon atmosphere at $-78{ }^{\circ} \mathrm{C}$. The deep red solution was stirred for 1 hour, and a solution of compound $\mathbf{B}(4.4 \mathrm{~g}, 15.4 \mathrm{mmol})$ in anhydrous THF $(15 \mathrm{~mL})$ was added at $-78{ }^{\circ} \mathrm{C}$. The obtained solution was heated to $50{ }^{\circ} \mathrm{C}$ and stirred for $3 \mathrm{~h}$. Saturated $\mathrm{NH}_{4} \mathrm{Cl}$ solution $(20 \mathrm{~mL})$ was added and then the solution was concentrated to dryness. The obtained red brown oil was dissolved in $20 \mathrm{~mL} \mathrm{H}_{2} \mathrm{O}$ and it was then extracted with $\mathrm{CH}_{2} \mathrm{Cl}_{2}(3 \times 50 \mathrm{~mL})$. The extracts were dried over $\mathrm{MgSO}_{4}$ and filtered, and were concentrated under reduced pressure to give the crude product as a yellow oil. The resulting yellow oil was passed through a short silica gel column with acetonitrile/ammonium hydroxide $(54: 1, \mathrm{v} / \mathrm{v})$ as the eluent. Pure product $\mathbf{C}$ was obtained as a yellow oil (2.15 g, yield: $50 \%)$.

${ }^{1} \mathbf{H}$ NMR (400 MHz, $\left.\mathrm{CDCl}_{3}\right): \delta 15.84(\mathrm{~s}, 1 \mathrm{H}), 8.54(\mathrm{~d}, J=4.7 \mathrm{~Hz}, 2 \mathrm{H}), 7.98(\mathrm{~d}, J=$ $8.3 \mathrm{~Hz}, 1 \mathrm{H}), 7.72-7.65(\mathrm{~m}, 4 \mathrm{H}), 7.62(\mathrm{~d}, J=9.1 \mathrm{~Hz}, 1 \mathrm{H}), 7.40(\mathrm{~d}, J=3.9 \mathrm{~Hz}, 2 \mathrm{H})$, $7.36(\mathrm{~d}, J=8.3 \mathrm{~Hz}, 1 \mathrm{H}), 7.13(\mathrm{t}, J=5.7 \mathrm{~Hz}, 2 \mathrm{H}), 6.88(\mathrm{~d}, J=9.1 \mathrm{~Hz}, 1 \mathrm{H}), 6.01(\mathrm{~s}$, $1 \mathrm{H}), 3.99(\mathrm{~s}, 4 \mathrm{H}), 3.46(\mathrm{~s}, 2 \mathrm{H}), 2.86(\mathrm{~s}, 3 \mathrm{H})$. 
${ }^{13}$ C NMR (100 MHz, $\left.\mathrm{CDCl}_{3}\right): \delta 192.64,159.43,159.11,151.97,149.22,149.00$, $137.17,136.45,135.75,134.57,126.67,123.92,123.39,122.99,122.37,121.93$, $121.77,121.10,90.11,62.91,60.71,25.51$.

HRMS (ESI): m/z: calcd for $\mathrm{C}_{28} \mathrm{H}_{26} \mathrm{~N}_{5} \mathrm{O}: 448.2132[\mathrm{M}+\mathrm{H}]^{+}$, found: 448.2120 .

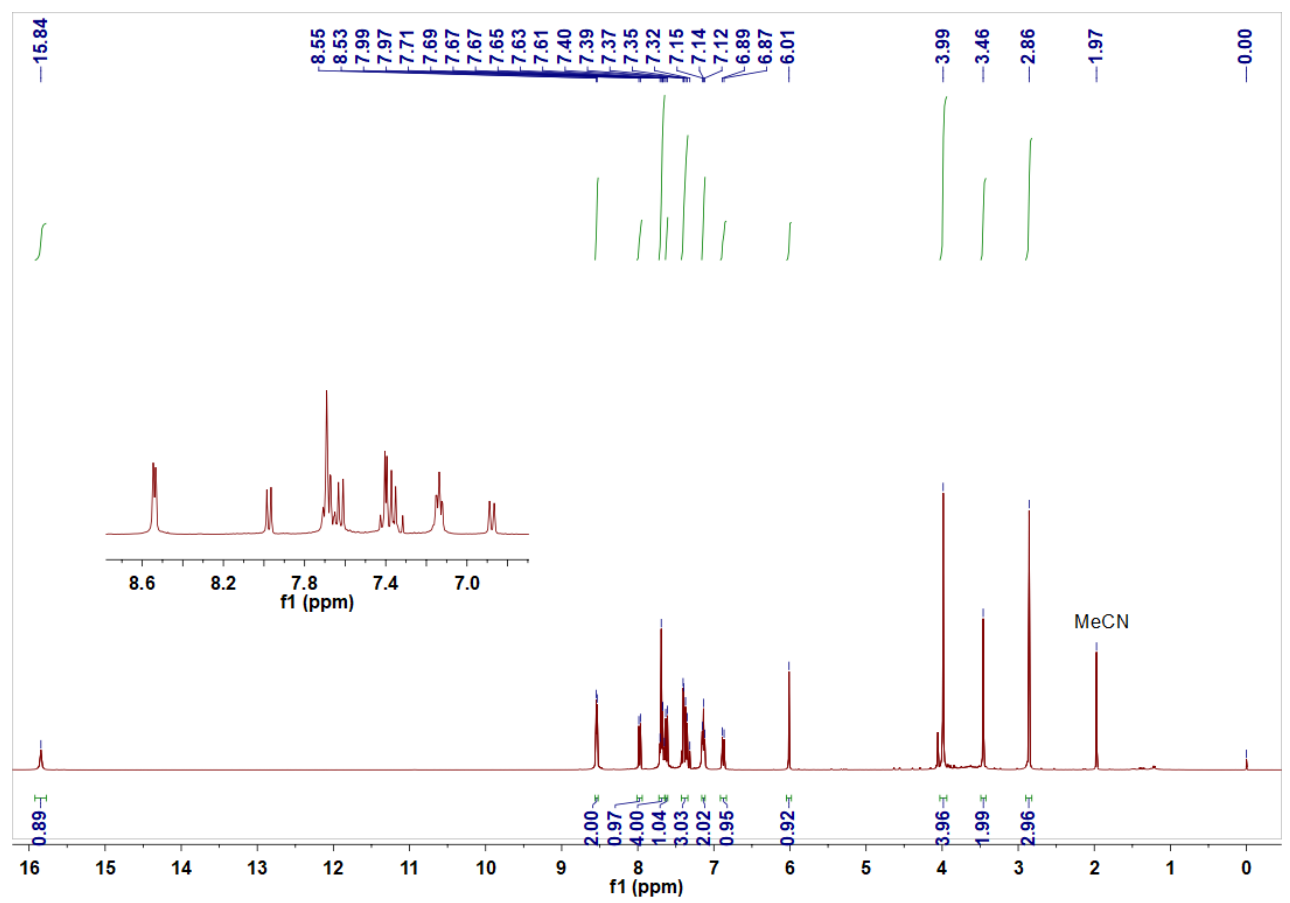

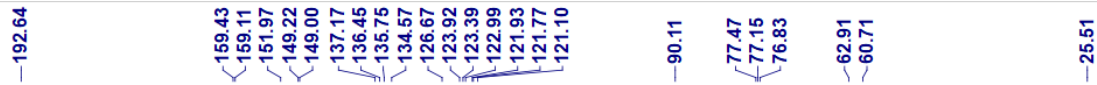

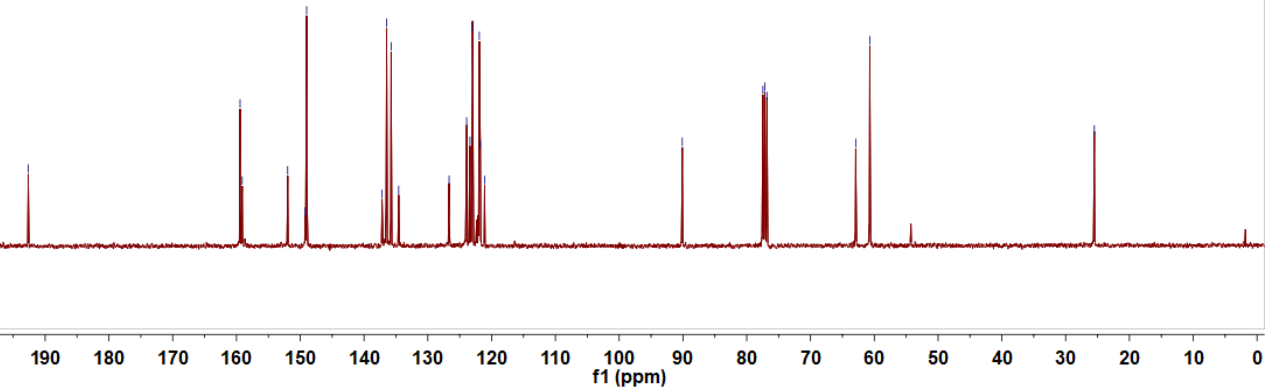




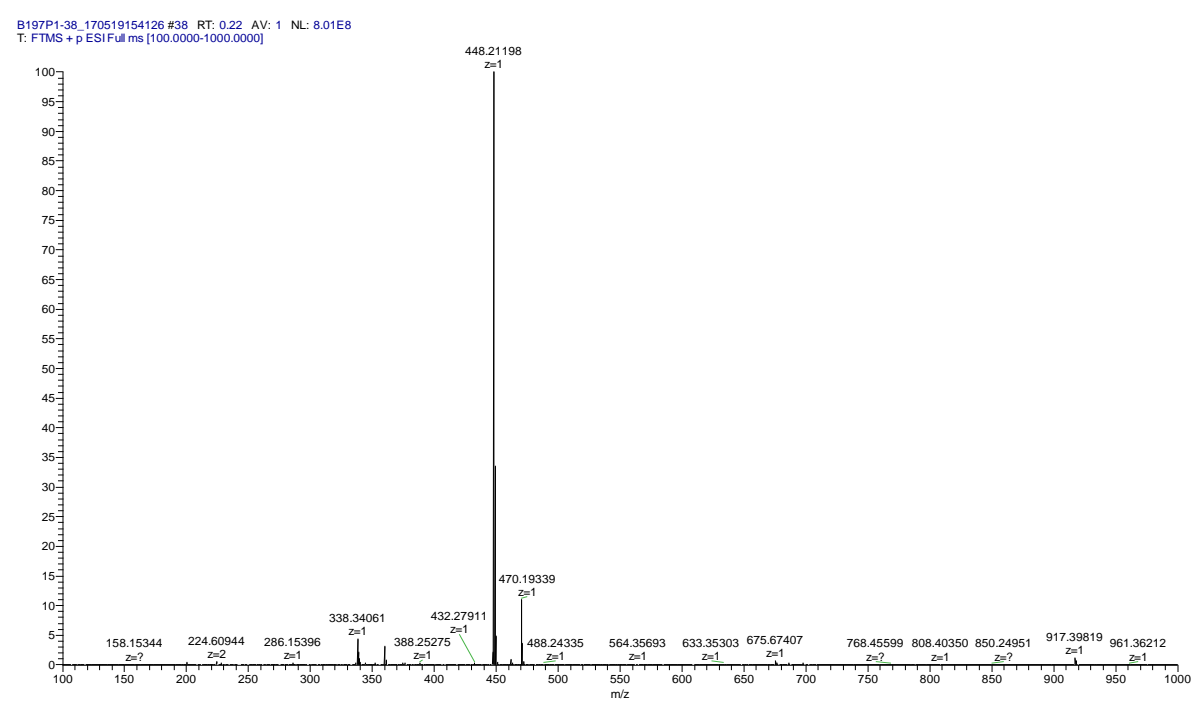

Figure S2 | NMR spectra and ESI-HRMS of compound C.

\subsection{Synthesis of $D$}

$\mathrm{NaBH}_{4}(1.03 \mathrm{~g}, 27.2 \mathrm{mmol})$ was added slowly into the solution of compound $\mathbf{C}$ (1.9 $\mathrm{g}, 4.2 \mathrm{mmol})$ in $\mathrm{CH}_{3} \mathrm{OH}(25 \mathrm{~mL})$ at $0{ }^{\circ} \mathrm{C}$. After 3 hours, the resulting solution was quenched with saturated $\mathrm{NH}_{4} \mathrm{Cl}$ solution $(10 \mathrm{~mL})$ and the solvent was evaporated. The obtained red brown oil was dissolved in $20 \mathrm{~mL} \mathrm{H} \mathrm{H}_{2} \mathrm{O}$ and extracted with $\mathrm{CH}_{2} \mathrm{Cl}_{2}(3 \mathrm{X}$ $50 \mathrm{~mL}$ ). The extracts were dried over $\mathrm{MgSO}_{4}$ and filtered, and were concentrated under reduced pressure to give the crude product as a yellow oil. The resulting yellow oil was passed through a short silica gel column with acetonitrile/ammonium hydroxide $(54: 1, \mathrm{v} / \mathrm{v})$ as the eluent. Pure product $\mathrm{D}$ was obtained as a yellow oil (1.51 g, yield: $80 \%)$.

${ }^{1} \mathbf{H}$ NMR $\left(400 \mathrm{MHz}, \mathrm{CDCl}_{3}\right): \delta 8.50(\mathrm{~d}, J=4.8 \mathrm{~Hz}, 2 \mathrm{H}), 8.11(\mathrm{~d}, J=8.2 \mathrm{~Hz}, 1 \mathrm{H})$, $8.07(\mathrm{~d}, J=8.2 \mathrm{~Hz}, 1 \mathrm{H}), 7.65(\mathrm{~m}, 3 \mathrm{H}), 7.53(\mathrm{~m}, 2 \mathrm{H}), 7.44(\mathrm{~d}, J=8.2 \mathrm{~Hz}, 1 \mathrm{H}), 7.37(\mathrm{~d}$, $J=7.8 \mathrm{~Hz}, 2 \mathrm{H}), 7.08(\mathrm{~m}, 2 \mathrm{H}), 4.52-4.44(\mathrm{~m}, 1 \mathrm{H}), 4.02(\mathrm{~d}, J=14.8 \mathrm{~Hz}, 2 \mathrm{H}), 3.93(\mathrm{~d}, J$ $=14.8 \mathrm{~Hz}, 2 \mathrm{H}), 3.33(\mathrm{dd}, J=14.6,3.5 \mathrm{~Hz}), 3.22(\mathrm{dd}, J=14.6,8.6 \mathrm{~Hz}, 1 \mathrm{H}), 2.97(\mathrm{dd}$, $J=13.1,3.8 \mathrm{~Hz}, 1 \mathrm{H}), 2.88-2.80(\mathrm{~m}, 4 \mathrm{H})$.

${ }^{13} \mathrm{C}$ NMR (100 MHz, $\left.\mathrm{CDCl}_{3}\right): \delta 160.52,159.40,159.19,148.92,145.22,144.95$, $136.34,136.21,136.08,127.13,126.69,125.61,125.30,123.69,123.38,123.09$, 121.92, 68.85, 60.91, 60.61, 43.36, 25.82.

HRMS (ESI): $\mathrm{m} / \mathrm{z}$ : calcd for $\mathrm{C}_{28} \mathrm{H}_{28} \mathrm{~N}_{5} \mathrm{O}: 450.2288[\mathrm{M}+\mathrm{H}]^{+}$, found: 450.2285 ; calcd for $\mathrm{C}_{28} \mathrm{H}_{27} \mathrm{~N}_{5} \mathrm{ONa}$ : $472.2108[\mathrm{M}+\mathrm{Na}]^{+}$, found: 472.2113; calcd for $\mathrm{C}_{28} \mathrm{H}_{29} \mathrm{~N}_{5} \mathrm{O}$ : $225.6181[\mathrm{M}+2 \mathrm{H}]^{2+}$, found: 225.6155 . 


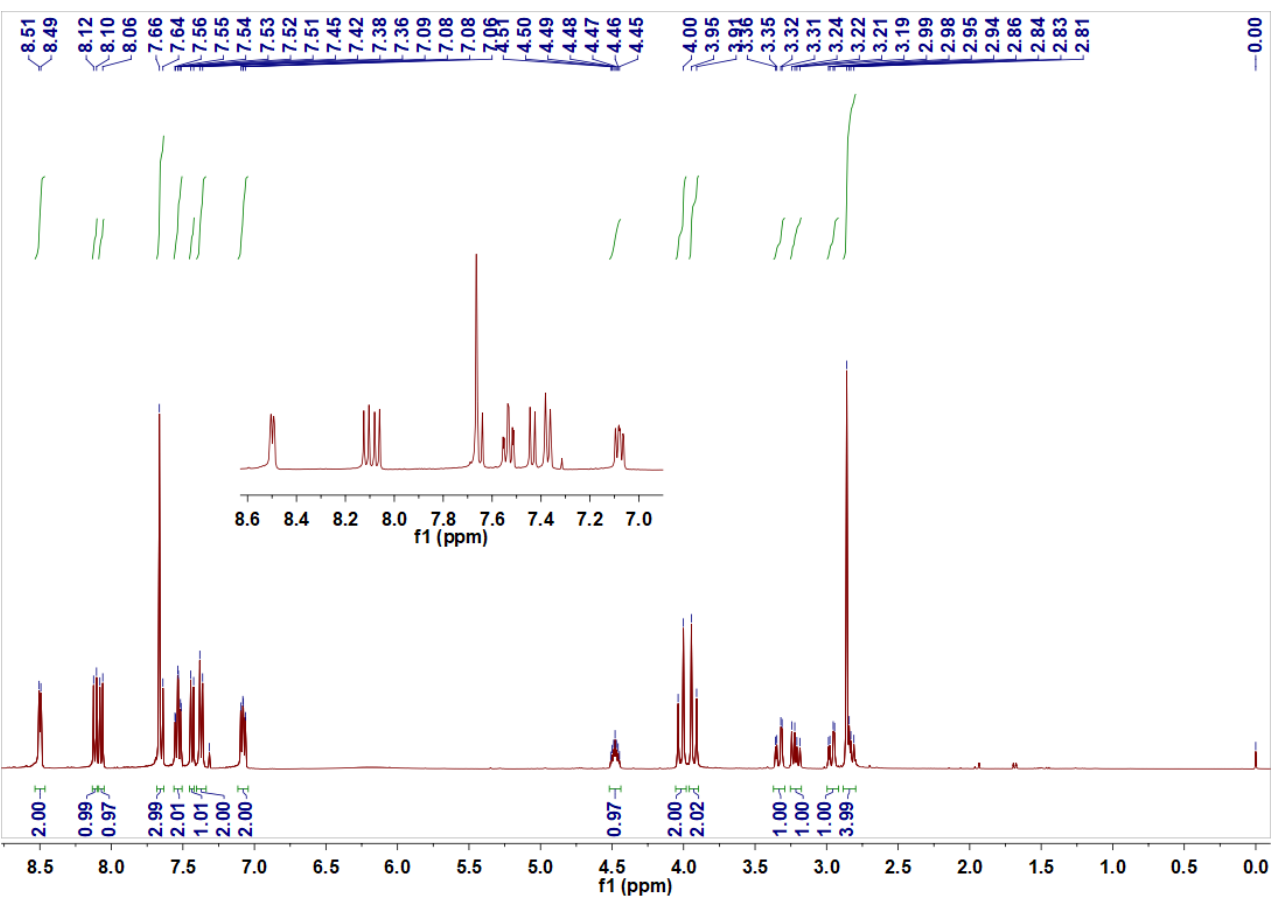

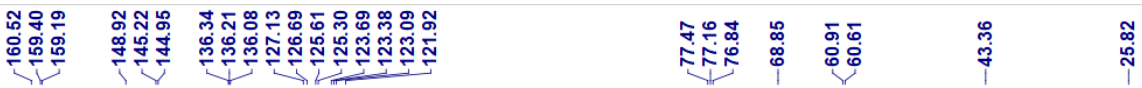

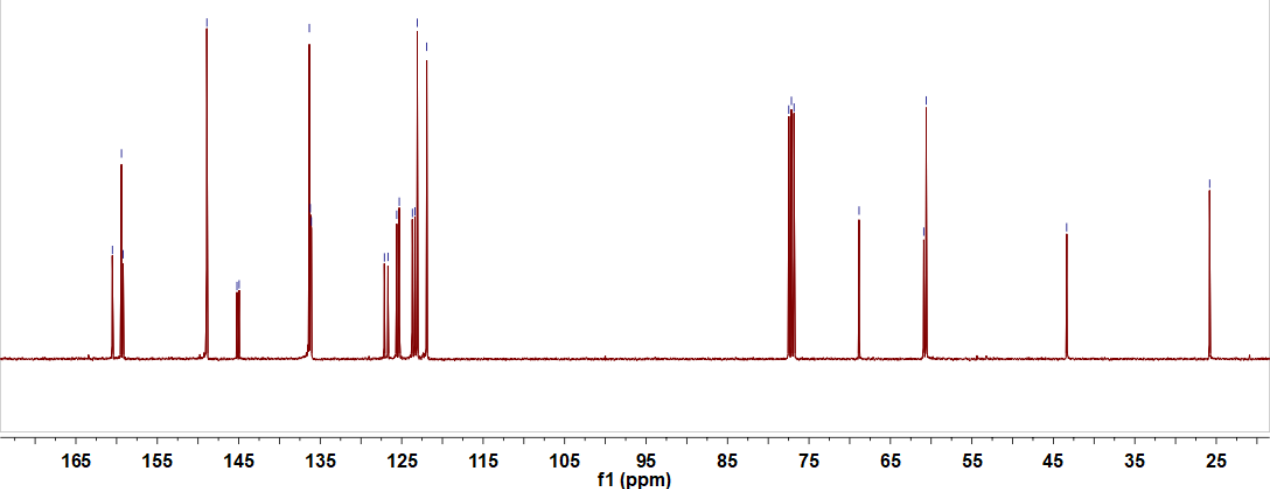




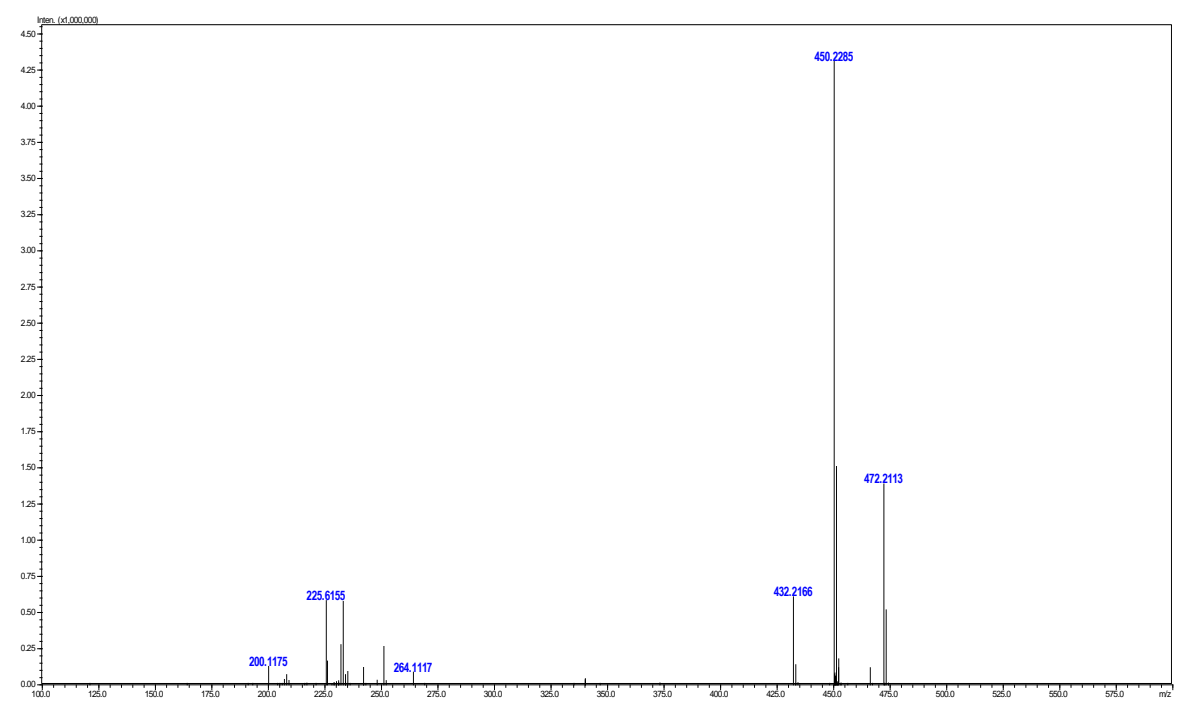

Figure S3 | NMR spectra and ESI-HRMS of compound D.

\subsection{Synthesis of $E$}

To solution of compound $\mathbf{D}(1 \mathrm{~g}, 2.2 \mathrm{mmol})$ in anhydrous THF $(25 \mathrm{~mL})$ was added dropwise over $50 \mathrm{~min}$ fresh LDA (1.6 M solution in THF, $15 \mathrm{~mL}, 24 \mathrm{mmol}$ ) under an argon atmosphere at $-78{ }^{\circ} \mathrm{C}$. The deep red solution was stirred for 1 hour, and a solution of compound $\mathbf{B}(942 \mathrm{mg}, 3.3 \mathrm{mmol})$ in anhydrous THF $(15 \mathrm{~mL})$ was added at $-78{ }^{\circ} \mathrm{C}$. The obtained solution was heated to $50{ }^{\circ} \mathrm{C}$ and stirred for $6 \mathrm{~h}$. Saturated $\mathrm{NH}_{4} \mathrm{Cl}$ solution $(20 \mathrm{~mL})$ was added and then the solution was concentrated to dryness. The obtained red brown oil was dissolved in $20 \mathrm{~mL} \mathrm{H}_{2} \mathrm{O}$ and it was then extracted with $\mathrm{CH}_{2} \mathrm{Cl}_{2}(3 \times 50 \mathrm{~mL})$. The combined extracts were dried over $\mathrm{MgSO}_{4}$ and filtered, and were concentrated under reduced pressure to give the crude product as a yellow oil. The residue was passed through a short silica gel column with acetonitrile/ammonium hydroxide $(54: 1, \mathrm{v} / \mathrm{v})$ as the eluent. Pure product $\mathbf{E}$ was obtained as a yellow oil (795 mg, yield: $35 \%$ ).

${ }^{1} \mathbf{H}$ NMR $\left(400 \mathrm{MHz}, \mathrm{CDCl}_{3}\right): \delta 16.00(\mathrm{~s}, 1 \mathrm{H}, \mathrm{OH}), 8.51(\mathrm{~d}, J=4.8 \mathrm{~Hz}, 2 \mathrm{H}), 8.43(\mathrm{~d}$, $J=4.3 \mathrm{~Hz}, 2 \mathrm{H}), 8.03(\mathrm{~d}, J=8.4 \mathrm{~Hz}, 1 \mathrm{H}), 7.68-7.63(\mathrm{~m}, 5 \mathrm{H}), 7.52-7.45(\mathrm{~m}, 5 \mathrm{H})$, $7.34(\mathrm{~d}, J=7.8 \mathrm{~Hz}, 2 \mathrm{H}), 7.12(\mathrm{~d}, J=4.2 \mathrm{~Hz}, 2 \mathrm{H}), 7.05-7.00(\mathrm{~m}, 2 \mathrm{H}), 6.89(\mathrm{~d}, J=9.1$ $\mathrm{Hz}, 1 \mathrm{H}), 5.96(\mathrm{~s}, 1 \mathrm{H}), 4.79(\mathrm{~m}, 1 \mathrm{H}), 4.07(\mathrm{~d}, J=14.6 \mathrm{~Hz}, 2 \mathrm{H}), 3.92-3.83(\mathrm{~m}, 6 \mathrm{H})$, 3.31 - $3.19(\mathrm{~m}, 4 \mathrm{H}), 2.96(\mathrm{~m}, 1 \mathrm{H}), 2.86(\mathrm{~m}, 1 \mathrm{H})$.

${ }^{13} \mathrm{C}$ NMR $\left(100 \mathrm{MHz}, \mathrm{CDCl}_{3}\right): \delta 160.28,159.48,159.35,152.04,149.12,148.90$, $136.47,136.33,135.84,127.15,124.70,124.14,123.30,122.94,121.93,121.87$, $121.12,90.00,77.34,77.02,76.71,67.91,62.74,60.69,60.61,60.43$.

HRMS (ESI): $\mathrm{m} / \mathrm{z}$ : calcd for $\mathrm{C}_{42} \mathrm{H}_{41} \mathrm{~N}_{8} \mathrm{O}_{2}: 689.3352[\mathrm{M}+\mathrm{H}]^{+}$, found: 689.3313 ; calcd for $\mathrm{C}_{42} \mathrm{H}_{40} \mathrm{~N}_{8} \mathrm{O}_{2} \mathrm{Na}: 711.3172\left[\mathrm{M}+\mathrm{Na}^{+}\right.$, found: 711.3127; calcd for $\mathrm{C}_{42} \mathrm{H}_{42} \mathrm{~N}_{8} \mathrm{O}_{2}: 345.1710[\mathrm{M}+2 \mathrm{H}]^{2+}$, found: 345.1693 . 

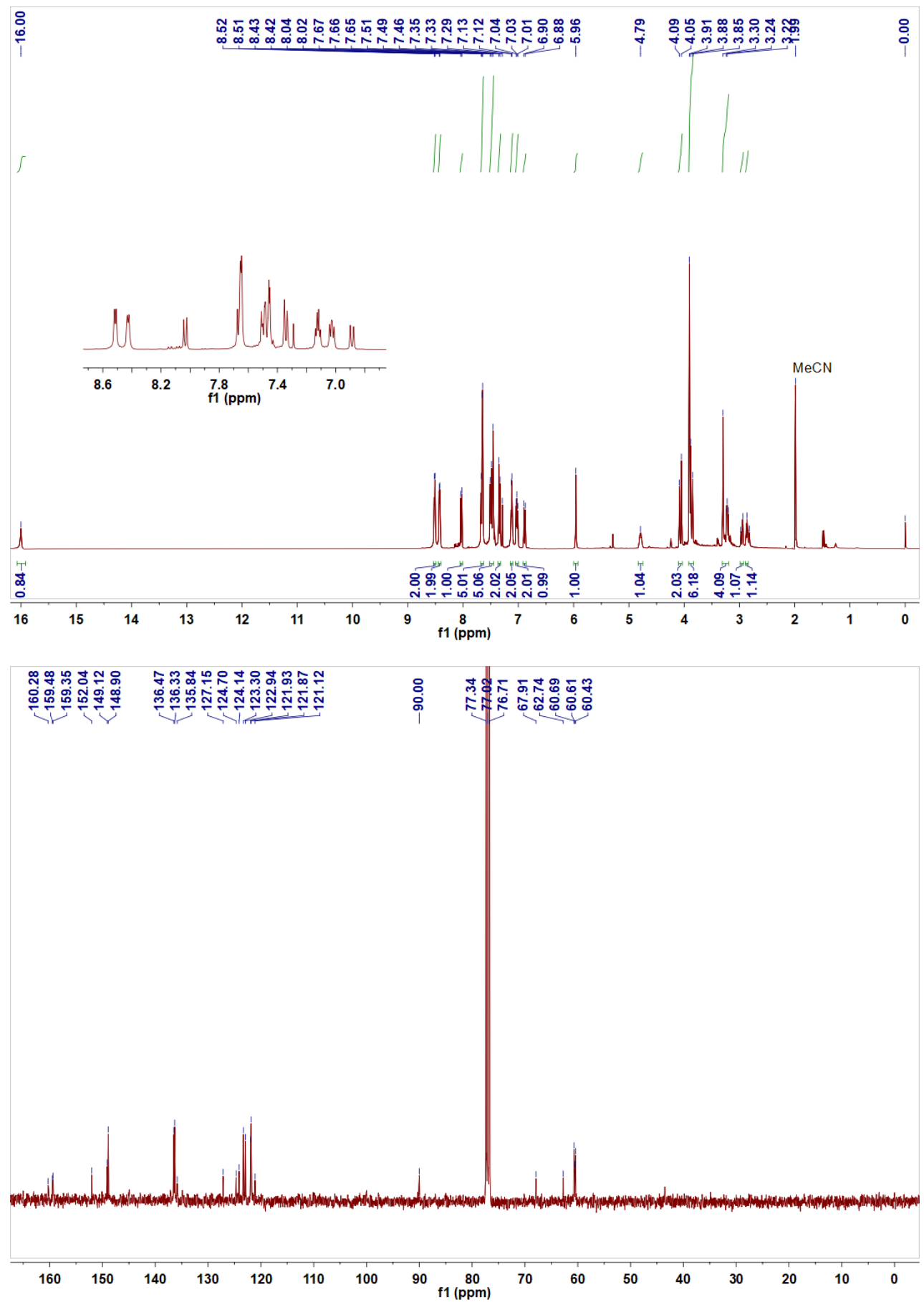


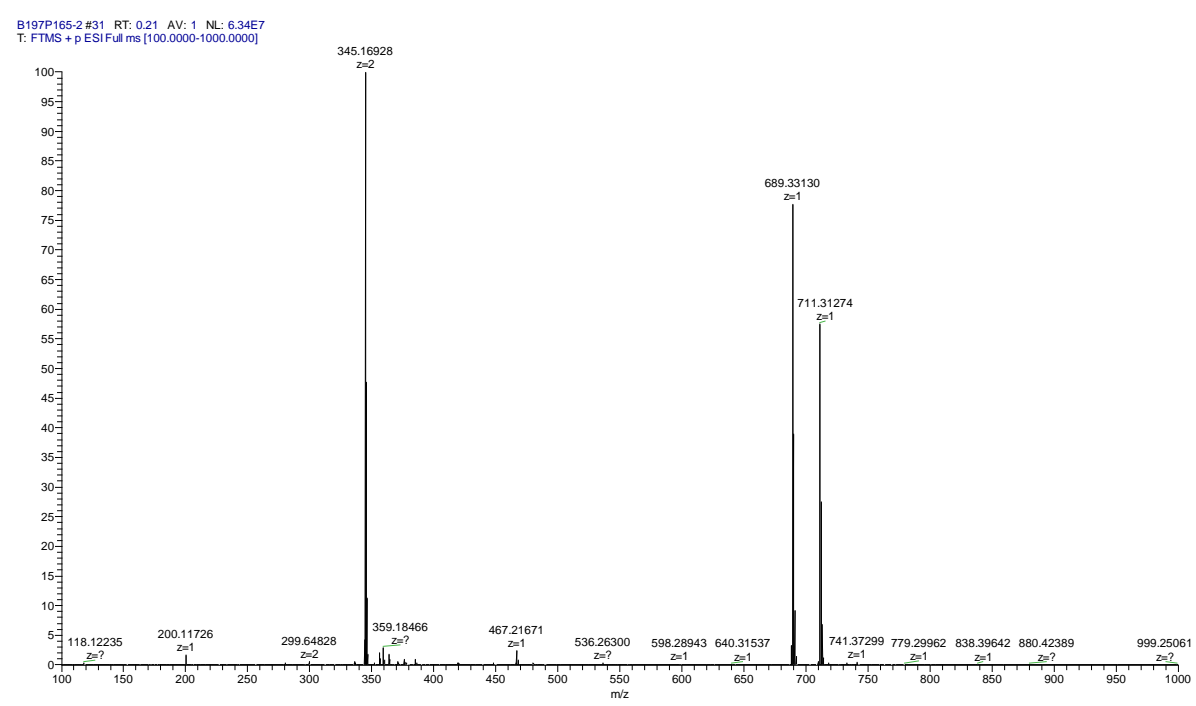

Figure S4 | NMR spectra and ESI-HRMS of compound $\mathbf{E}$.

\subsection{Synthesis of $\mathbf{F}\left(\mathrm{H}_{2} \mathrm{app}\right)$}

$\mathrm{NaBH}_{4}(276.2 \mathrm{mg}, 7.3 \mathrm{mmol})$ was added slowly into the solution of compound $\mathbf{E}$ (500 mg, $0.7 \mathrm{mmol})$ in $\mathrm{CH}_{3} \mathrm{OH}(10 \mathrm{~mL})$ at $0{ }^{\circ} \mathrm{C}$. After 3 hours, the resulting solution was quenched with saturated $\mathrm{NH}_{4} \mathrm{Cl}$ solution $(10 \mathrm{~mL})$ and the solvent was evaporated. The obtained red brown oil was dissolved in $20 \mathrm{~mL} \mathrm{H}_{2} \mathrm{O}$ and extracted with $\mathrm{CH}_{2} \mathrm{Cl}_{2}$ $(3 \times 50 \mathrm{~mL})$. The extracts were dried over $\mathrm{MgSO}_{4}$ and filtered, and were concentrated under reduced pressure to give the crude product. The resulting yellow oil was passed through a short silica gel column with acetonitrile/ammonium hydroxide $(27: 1, \mathrm{v} / \mathrm{v})$ as the eluent. Pure product $\mathbf{F}$ was obtained as a yellow solid (403 mg, yield: $80 \%$ ).

${ }^{1} \mathbf{H}$ NMR $\left(400 \mathrm{MHz}, \mathrm{CD}_{3} \mathrm{CN} \_\mathrm{SPE}\right) \delta 8.33(\mathrm{~m}, 4 \mathrm{H}), 8.23(\mathrm{~d}, J=8.2 \mathrm{~Hz}, 2 \mathrm{H}), 7.79$ $(\mathrm{d}, J=1.4 \mathrm{~Hz}, 2 \mathrm{H}), 7.58-7.46(\mathrm{~m}, 6 \mathrm{H}), 7.32(\mathrm{~m}, 4 \mathrm{H}), 7.05(\mathrm{~m}, 4 \mathrm{H}), 4.41-4.28(\mathrm{~m}$, $2 \mathrm{H}), 3.86$ - $3.74(\mathrm{~m}, 8 \mathrm{H}), 3.14-3.08(\mathrm{~m}, 2 \mathrm{H}), 2.98$ - $2.91(\mathrm{~m}, 2 \mathrm{H}), 2.73$ - $2.67(\mathrm{~m}, 2 \mathrm{H})$, $2.64-2.57(\mathrm{~m}, 2 \mathrm{H})$.

${ }^{13} \mathrm{C}$ NMR (100 MHz, CD 3 CN_SPE) $\delta 160.33,159.07,148.69,144.26,136.54$, 136.36, 127.13, 125.64, 123.89, 123.14, 121.99, 68.63, 60.43, 60.27, 42.77 .

HRMS (ESI): $\mathrm{m} / \mathrm{z}$ : calcd for $\mathrm{C}_{42} \mathrm{H}_{43} \mathrm{~N}_{8} \mathrm{O}_{2}: 691.3503[\mathrm{M}+\mathrm{H}]^{+}$, found: 691.3500; calcd for $\mathrm{C}_{42} \mathrm{H}_{42} \mathrm{~N}_{8} \mathrm{O}_{2} \mathrm{Na}$ : $713.3323\left[\mathrm{M}+\mathrm{Na}^{+}\right.$, found: 713.3317; calcd for $\mathrm{C}_{42} \mathrm{H}_{44} \mathrm{~N}_{8} \mathrm{O}_{2}: 346.1788[\mathrm{M}+2 \mathrm{H}]^{2+}$, found: 346.1790 . 

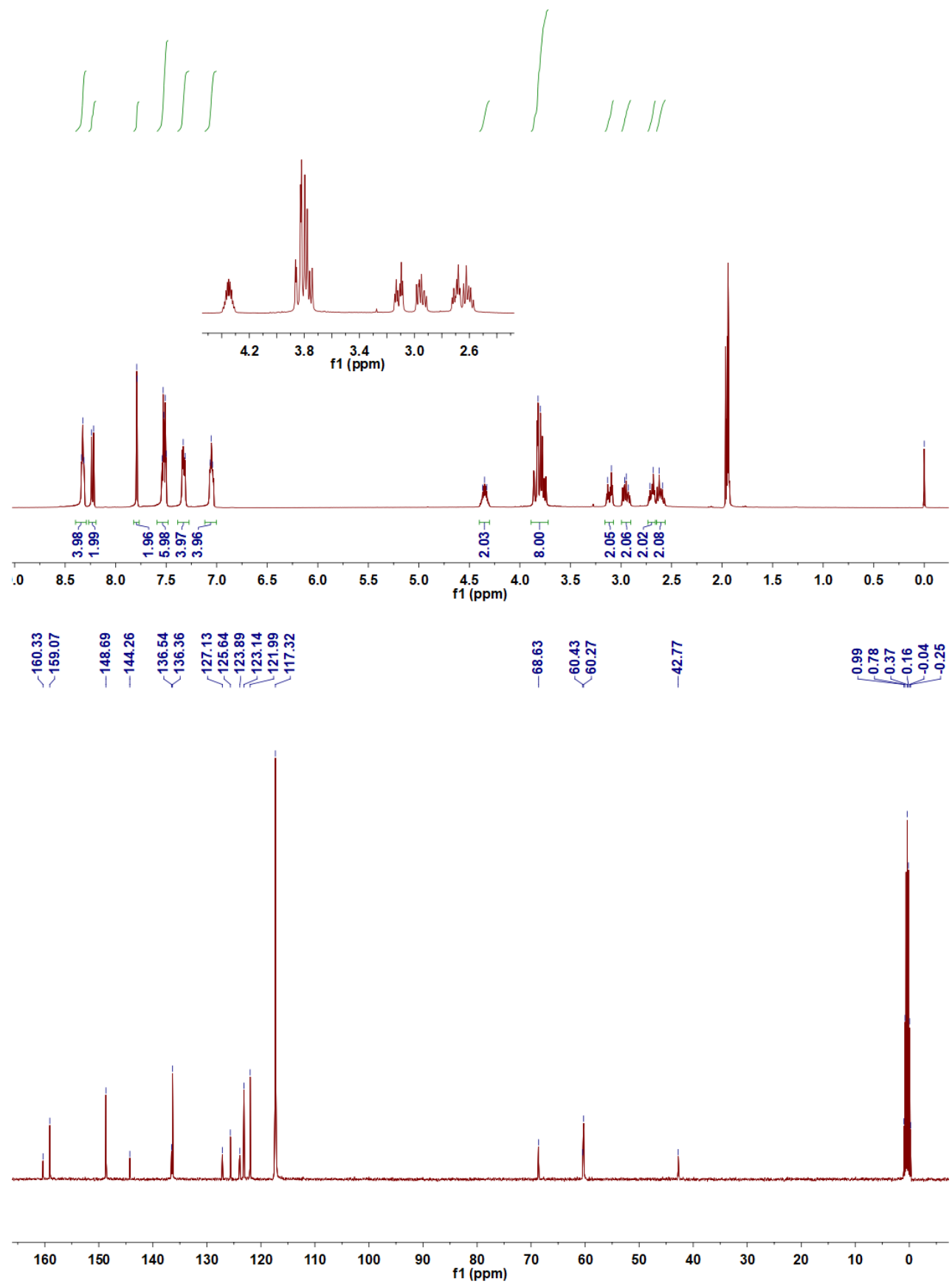


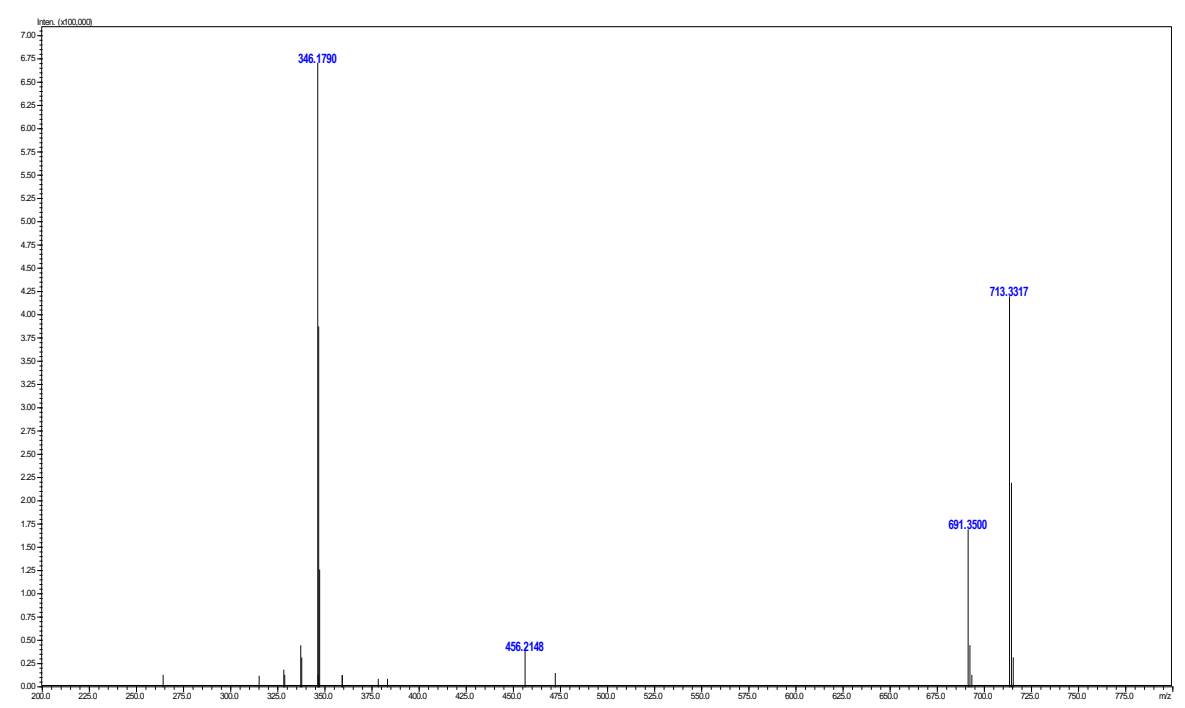

Figure S5 | NMR spectra and ESI-HRMS of compound F.

\subsection{Synthesis of catalyst TNC-Cu}

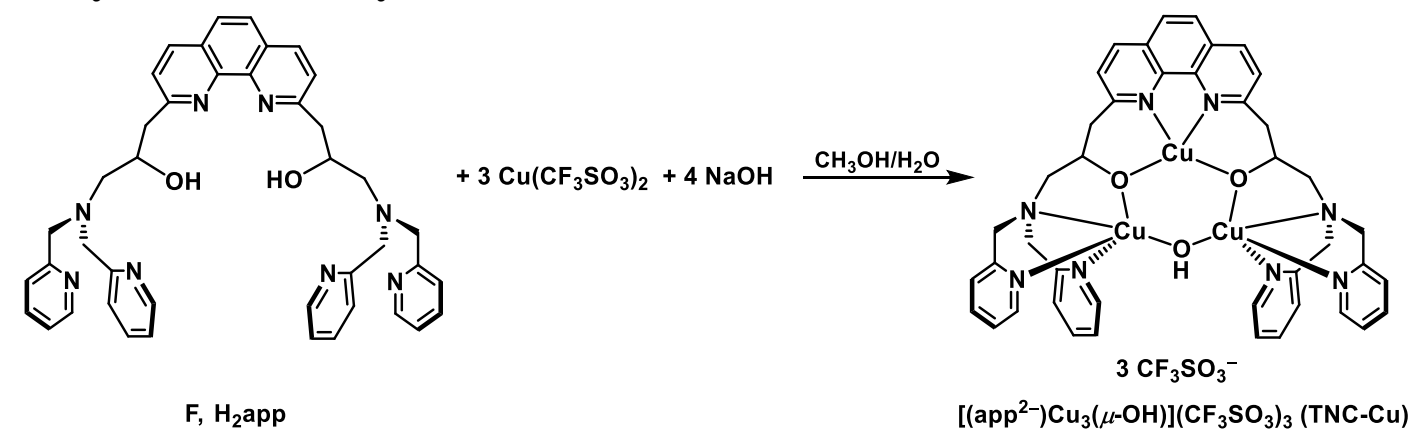

To solution of copper(II) triflate $(781.2 \mathrm{mg}, 2.2 \mathrm{mmol})$ in $\mathrm{CH}_{3} \mathrm{OH} / \mathrm{H}_{2} \mathrm{O}(1: 1$, v/v, 5 $\mathrm{mL})$ was added dropwise a $\mathrm{CH}_{3} \mathrm{OH} / \mathrm{H}_{2} \mathrm{O}(1: 1$, v/v, $10 \mathrm{~mL})$ solution of compound $\mathbf{F}$ (500 mg, $0.7 \mathrm{mmol})$ and $\mathrm{NaOH}(115.2 \mathrm{mg}, 2.9 \mathrm{mmol})$. The colour of the clear solution changed immediately from yellow to brown-yellow. After 2 hours, the solution was evaporated and repeatedly recrystallized from $\mathrm{MeCN} /$ diethyl ether to afford [( $\left.\left.\operatorname{app}^{2-}\right) \mathrm{Cu}_{3}(\mu-\mathrm{OH})\right]\left(\mathrm{CF}_{3} \mathrm{SO}_{3}\right)_{3}$ as a brown solid (600 mg, yield: $\left.62 \%\right)$. Crystals of $\left[\left(\mathrm{app}^{2-}\right) \mathrm{Cu}_{3}(\mu-\mathrm{OH})\right]\left(\mathrm{CF}_{3} \mathrm{SO}_{3}\right)_{3}$ suitable for X-ray crystallography were obtained by recrystallization from $\mathrm{MeCN} /$ diethyl ether by slow vaporization under air.

HRMS (ESI): $\mathrm{m} / \mathrm{z}$ : calcd for $\left[\left(\mathrm{app}^{2-}\right) \mathrm{Cu}_{3}(\mu-\mathrm{OH})\right]^{3+}$ in $\mathrm{MeCN}: 298.7058[\mathrm{M}]^{3+}$, found: 298.7056; calcd for $\left[\left(\operatorname{app}^{2-}\right) \mathrm{Cu}_{3}(\mu-\mathrm{OH})\right]^{3+}$ in water: $298.7058[\mathrm{M}]^{3+}$, found: 298.7057. 


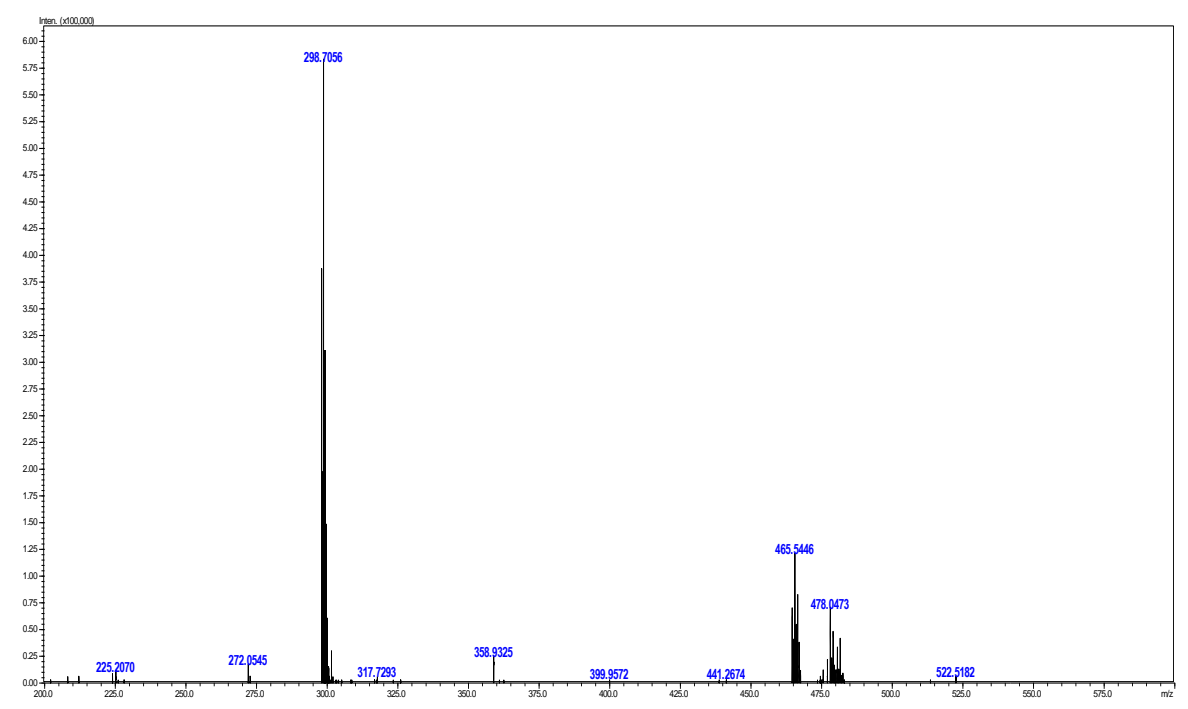

Figure S6 | ESI-HRMS of TNC-Cu in MeCN
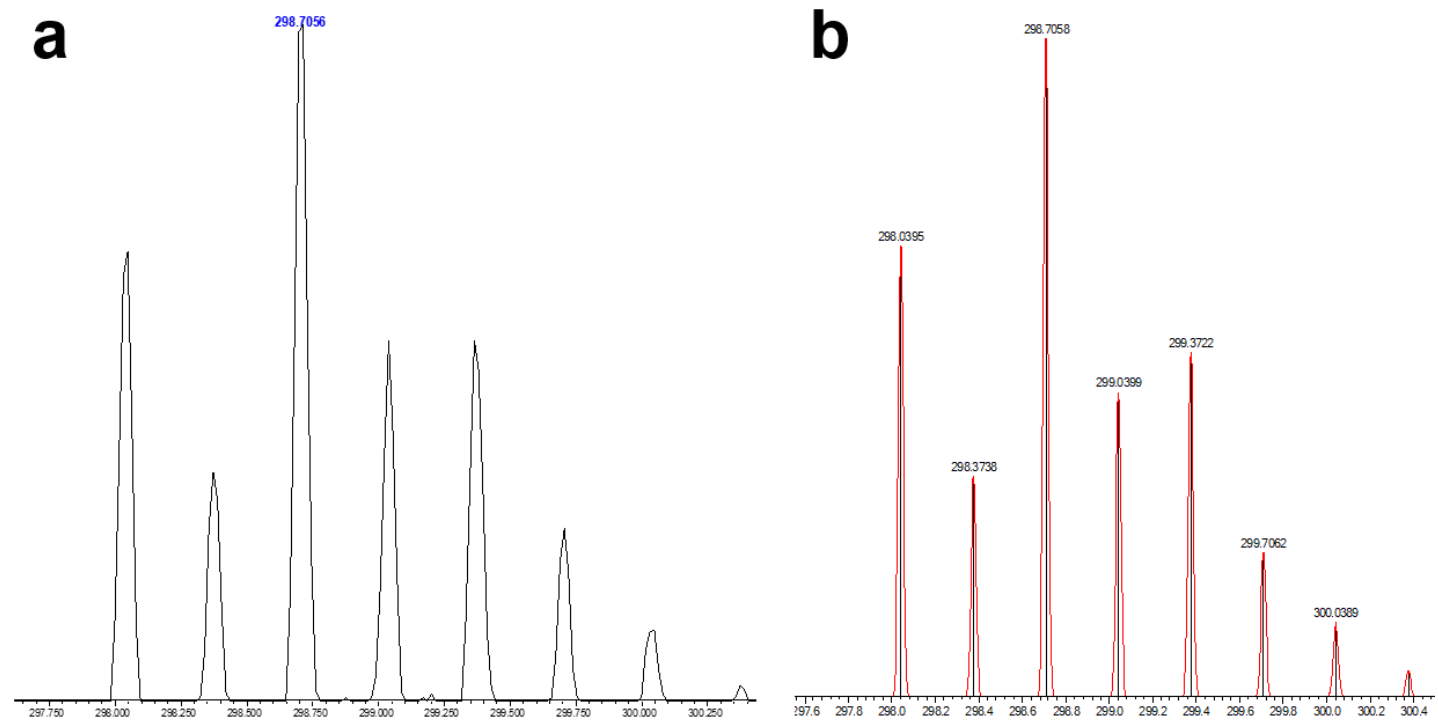

Figure S7 | Enlarged ESI-HRMS spectra of the experimental (a) and calculated (b) $\mathrm{m} / \mathrm{z}$ values of $\left[\left(\operatorname{app}^{2-}\right) \mathrm{Cu}_{3}(\mu-\mathrm{OH})\right]^{3+}$ in $\mathrm{MeCN}$. 

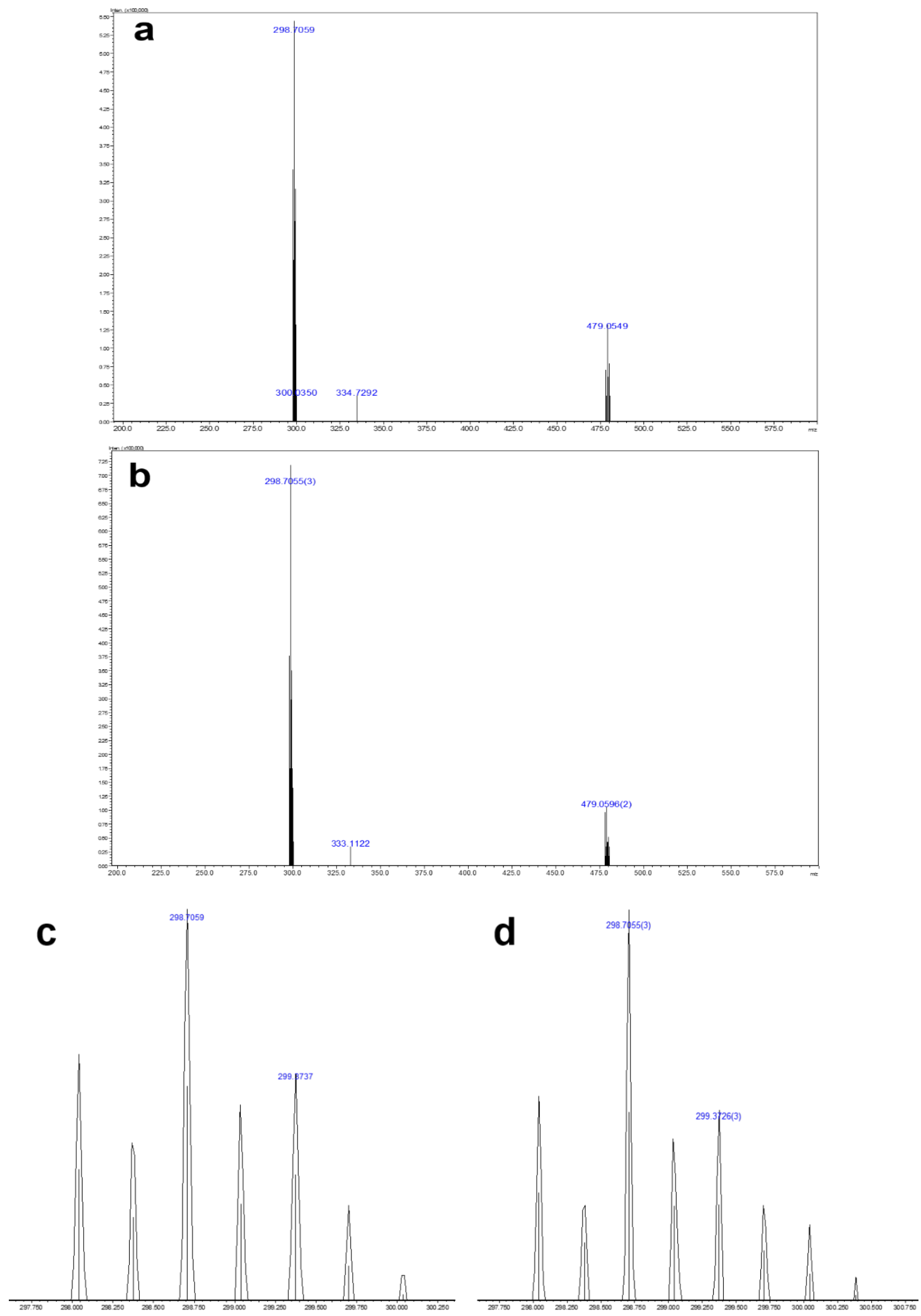

Figure $\mathbf{S 8} \mid$ ESI-HRMS of TNC-Cu in water (a) and $\mathrm{NaHCO}_{3}(1 \mathrm{M}, \mathrm{pH} 8.4, \mathbf{b})$; Enlarged ESI-HRMS spectra of $m / z$ values of $\left[\left(\operatorname{app}^{2-}\right) \mathrm{Cu}_{3}(\mu-\mathrm{OH})\right]^{3+}$ in water $(\mathbf{c})$ and $\mathrm{NaHCO}_{3}$ (1 M, pH 8.4, d). 


\section{Section 3: Synthesis and characterization of $\mathrm{F}-\mathrm{N}_{2} \mathrm{O}_{2} \mathrm{Cu}$ and $\mathrm{HappCu} 2$}

\subsection{Synthesis of catalyst HappCu2}
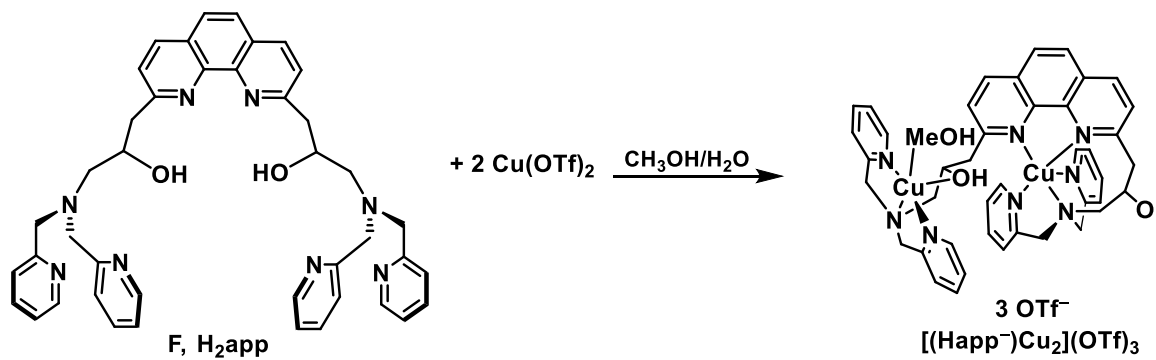

To solution of copper(II) triflate $(434 \mathrm{mg}, 1.2 \mathrm{mmol})$ in $\mathrm{CH}_{3} \mathrm{OH} / \mathrm{H}_{2} \mathrm{O}(1: 1$, v/v, 20 $\mathrm{mL})$ was added dropwise a $\mathrm{CH}_{3} \mathrm{OH} / \mathrm{H}_{2} \mathrm{O}(1: 1, \mathrm{v} / \mathrm{v}, 20 \mathrm{~mL})$ solution of compound $\mathbf{F}$ (414.2 $\mathrm{mg}, 0.6 \mathrm{mmol}$ ). The colour of the clear solution changed immediately from yellow to deep green. After 2 hours, the solution was evaporated and repeatedly recrystallized from $\mathrm{MeCN} /$ diethyl ether to afford $\left[\left(\mathrm{Happ}^{-}\right) \mathrm{Cu}_{2}\right](\mathrm{OTf})_{3}\left(\mathrm{HappCu}_{2}\right)$ as a deep green solid (675 mg, yield: $88 \%$ ). Crystals of [(Happ $\left.\left.{ }^{-}\right) \mathrm{Cu}_{2}\right](\mathrm{OTf})_{3}$ suitable for X-ray crystallography were obtained by recrystallization from $\mathrm{CH}_{3} \mathrm{OH} /$ diethyl ether by slow vaporization under air.

HRMS (ESI): $\mathrm{m} / \mathrm{z}$ : calcd for $\left[\left(\mathrm{app}^{2-}\right) \mathrm{Cu}_{2}\right]^{2+}: 408.0926[\mathrm{M}]^{2+}$, found: 408.0929; calcd for $[\mathrm{M}+\mathrm{H}+\mathrm{OTf}]^{2+}: 483.0725$, found: 483.0731 .

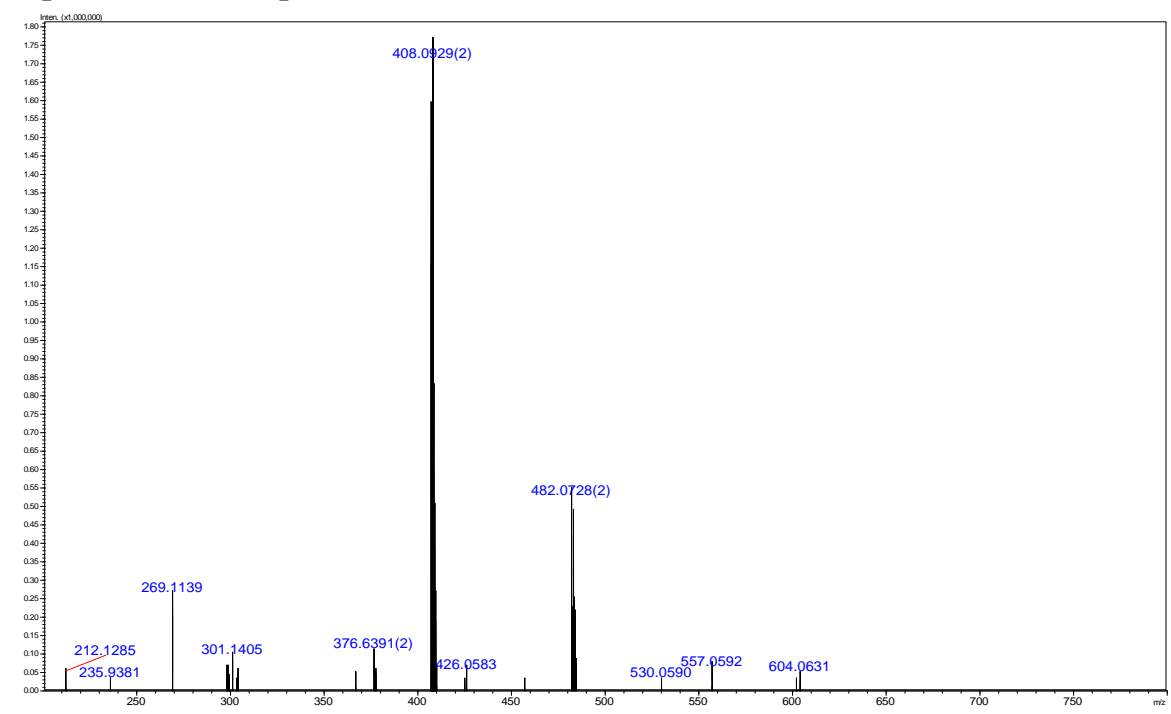

Figure S9 | ESI-HRMS of $\left[\left(\mathrm{Happ}^{-}\right) \mathrm{Cu}_{2}\right](\mathrm{OTf})_{3}$ in $\mathrm{MeCN}$. 

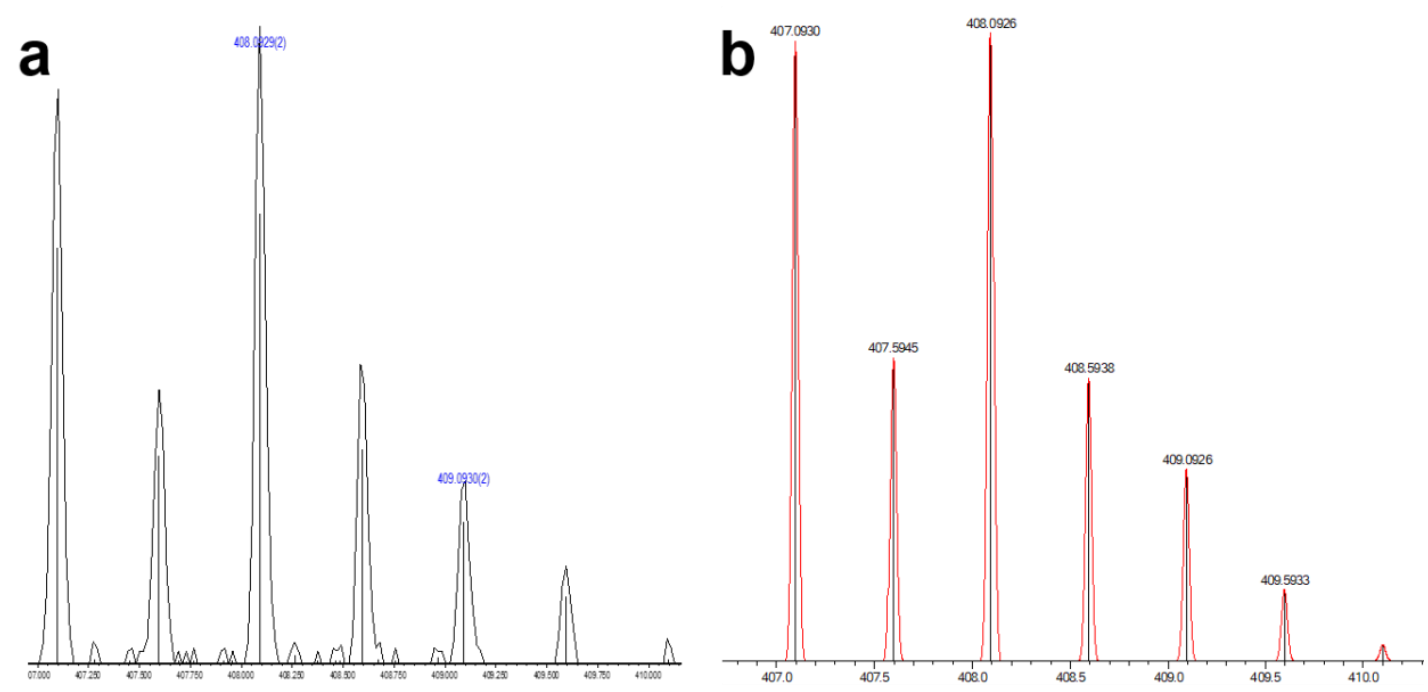

Figure S10 | Enlarged ESI-HRMS spectra of the experimental (a) and calculated $(\mathbf{b}) \mathrm{m} / \mathrm{z}$ values $(\mathrm{m} / \mathrm{z}=408.0929)$ of $\left[\left(\mathrm{Happ}^{-}\right) \mathrm{Cu}_{2}\right](\mathrm{OTf})_{3}$ in $\mathrm{MeCN}$.
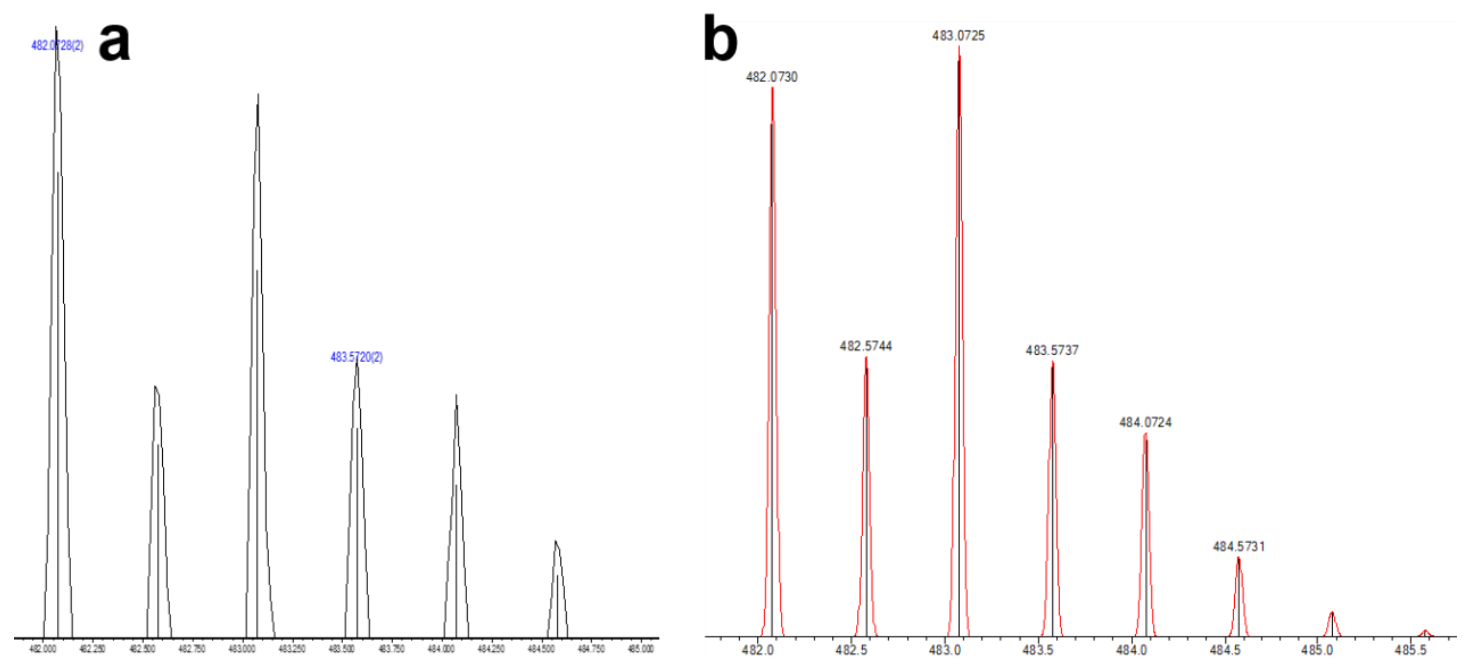

Figure S11 | Enlarged ESI-HRMS spectra of the experimental (a) and calculated (b) $\mathrm{m} / \mathrm{z}$ values $(\mathrm{m} / \mathrm{z}=482.0728)$ of $\left[\left(\mathrm{Happ}^{-}\right) \mathrm{Cu}_{2}\right](\mathrm{OTf})_{3}$ in $\mathrm{MeCN}$.

\subsection{Synthesis of ligand $\mathrm{F}-\mathrm{N}_{2} \mathrm{O}_{2}$}

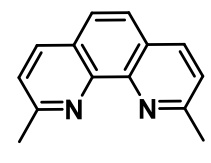

A

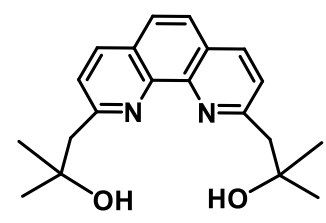

$\mathrm{F}-\mathrm{N}_{2} \mathrm{O}_{2}, 48 \%$

To solution of 2,9-dimethyl-1,10-phenanthroline $\mathbf{A}(2 \mathrm{~g}, 9.6 \mathrm{mmol})$ in anhydrous THF (25 mL) was added dropwise over $50 \mathrm{~min}$ fresh LDA (1.6 M solution in THF, 18 $\mathrm{mL}, 28.8 \mathrm{mmol})$ under an argon atmosphere at $-78^{\circ} \mathrm{C}$. The deep red solution was stirred for 1 hour, and a solution of acetone $(1.67 \mathrm{~g}, 28.8 \mathrm{mmol})$ in anhydrous THF $(15 \mathrm{~mL})$ was added at $-78^{\circ} \mathrm{C}$. The obtained solution was heated to $-20{ }^{\circ} \mathrm{C}$ and stirred for $3 \mathrm{~h}$. Saturated $\mathrm{NH}_{4} \mathrm{Cl}$ solution $(20 \mathrm{~mL})$ was added and then the solution was 
concentrated to dryness. The obtained red brown oil was dissolved in $20 \mathrm{~mL} \mathrm{H}_{2} \mathrm{O}$ and it was then extracted with $\mathrm{CH}_{2} \mathrm{Cl}_{2}(3 \times 50 \mathrm{~mL})$. The extracts were dried over $\mathrm{MgSO}_{4}$ and filtered, and were concentrated under reduced pressure to give the crude product as a yellow solid. The resulting yellow solid was passed through a short silica gel column with acetonitrile/ammonium hydroxide $(108: 1, \mathrm{v} / \mathrm{v})$ as the eluent. Pure product $\mathrm{F}-\mathrm{N}_{2} \mathrm{O}_{2}$ was obtained as a yellow solid (1.5 g, yield: $48 \%$ ).

${ }^{1} \mathbf{H}$ NMR $\left(400 \mathrm{MHz}, \mathrm{CDCl}_{3}\right): \delta 8.19(\mathrm{~d}, J=8.2 \mathrm{~Hz}, 2 \mathrm{H}), 7.75(\mathrm{~s}, 2 \mathrm{H}), 7.47$ (d, $J=$ $8.2 \mathrm{~Hz}, 2 \mathrm{H}), 6.11(\mathrm{~s}, 2 \mathrm{H}), 3.23(\mathrm{~s}, 4 \mathrm{H}), 1.31(\mathrm{~s}, 12 \mathrm{H})$.

${ }^{13} \mathrm{C}$ NMR $\left(100 \mathrm{MHz}, \mathrm{CDCl}_{3}\right): \delta 160.80,144.43,136.52,127.06,125.68,124.48$, $70.84,49.49,29.72$.

HRMS (ESI): $\mathrm{m} / \mathrm{z}$ : calcd for $\mathrm{C}_{20} \mathrm{H}_{25} \mathrm{~N}_{2} \mathrm{O}_{2}: 325.1916[\mathrm{M}+\mathrm{H}]^{+}$, found: 325.1897; calcd for $\mathrm{C}_{20} \mathrm{H}_{24} \mathrm{~N}_{2} \mathrm{O}_{2} \mathrm{Na}$ : $347.1735\left[\mathrm{M}+\mathrm{Na}^{+}\right.$, found: 347.1713 ; calcd for $\mathrm{C}_{40} \mathrm{H}_{48} \mathrm{~N}_{4} \mathrm{O}_{4} \mathrm{Na}: 671.3568$ [2 M + Na] $]^{+}$, found: 671.3543 .

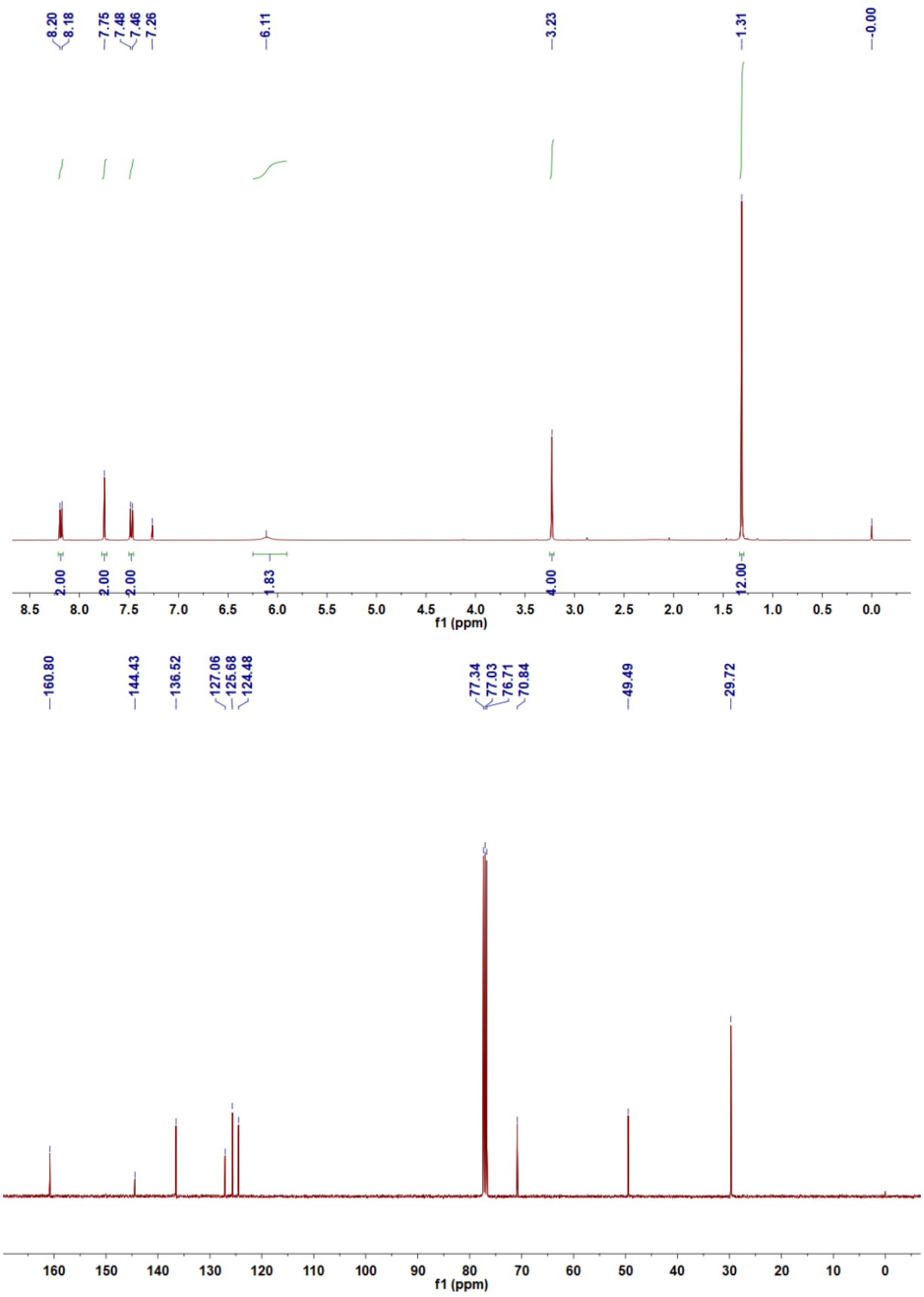




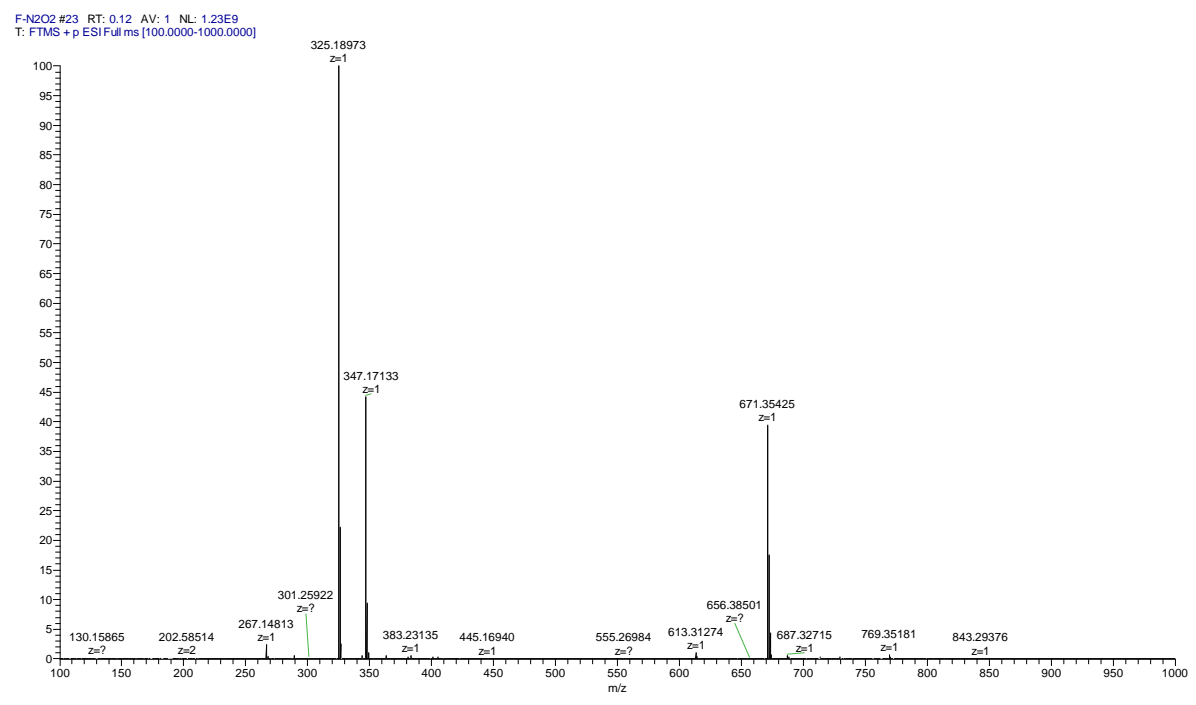

Figure S12 | NMR spectra and ESI-HRMS of ligand $\mathrm{F}-\mathrm{N}_{2} \mathrm{O}_{2}$.

\subsection{Synthesis of catalyst $\mathrm{F}-\mathrm{N}_{2} \mathrm{O}_{2} \mathrm{Cu}$}

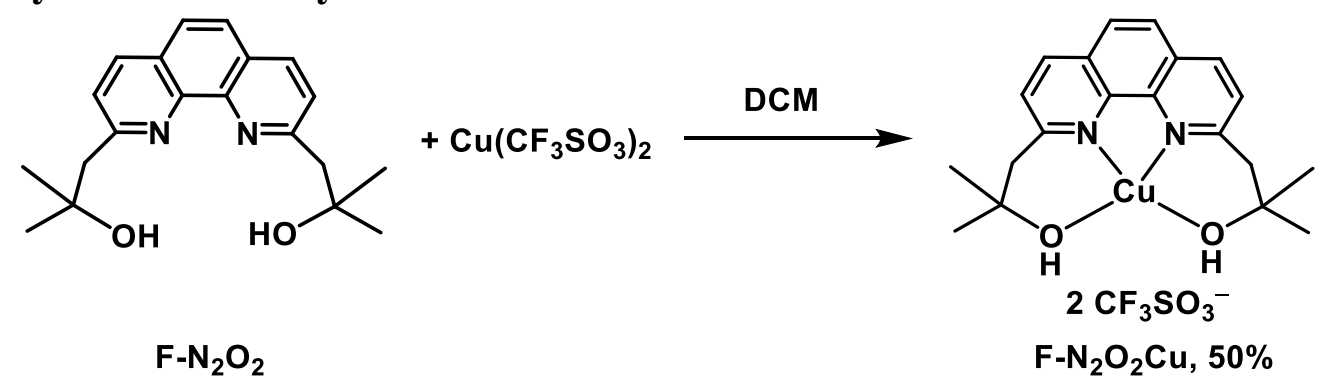

To solution of copper(II) triflate $(361.7 \mathrm{mg}, 1 \mathrm{mmol})$ in DCM $(20 \mathrm{~mL})$ was added dropwise a DCM $(20 \mathrm{~mL})$ solution of ligand $\mathrm{F}-\mathrm{N}_{2} \mathrm{O}_{2}(324.4 \mathrm{mg}, 1 \mathrm{mmol})$. After 1 day, the solution was filtered and the blue solid was obtained. The above solid was recrystallized from MeCN/diethyl ether to afford $\mathrm{F}-\mathrm{N}_{2} \mathrm{O}_{2} \mathrm{Cu}$ as a blue crystal (343 $\mathrm{mg}$, yield: $50 \%$ ), which was suitable for $\mathrm{X}$-ray crystallography test.

HRMS (ESI): $\mathrm{m} / \mathrm{z}$ : calcd for $\left[\mathrm{F}-\mathrm{N}_{2} \mathrm{O}_{2} \mathrm{Cu}\right]^{2+}$ : $193.5561[\mathrm{M}]^{2+}$, found: 193.5566; calcd for $[\mathrm{M}+\mathrm{MeCN}]^{2+}: 214.0697$, found: 214.0678 .

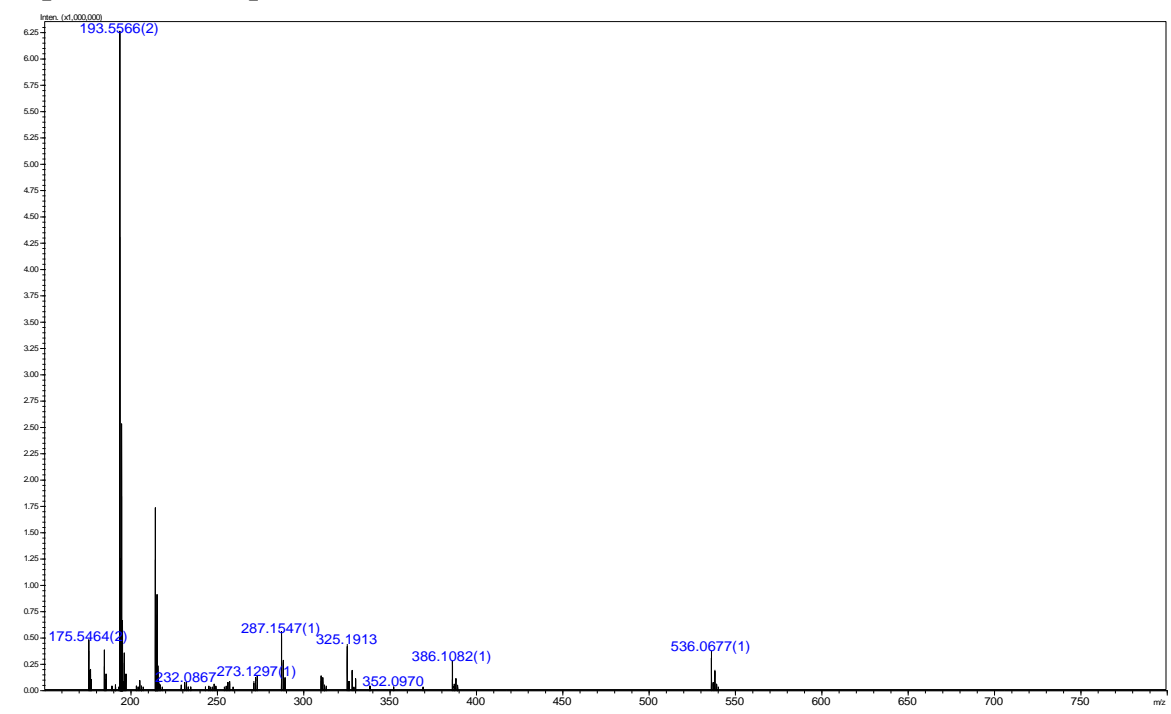

Figure S13 | ESI-HRMS of $\left[\mathrm{F}-\mathrm{N}_{2} \mathrm{O}_{2} \mathrm{Cu}\right](\mathrm{OTf})_{2}$ in $\mathrm{MeCN}$. 

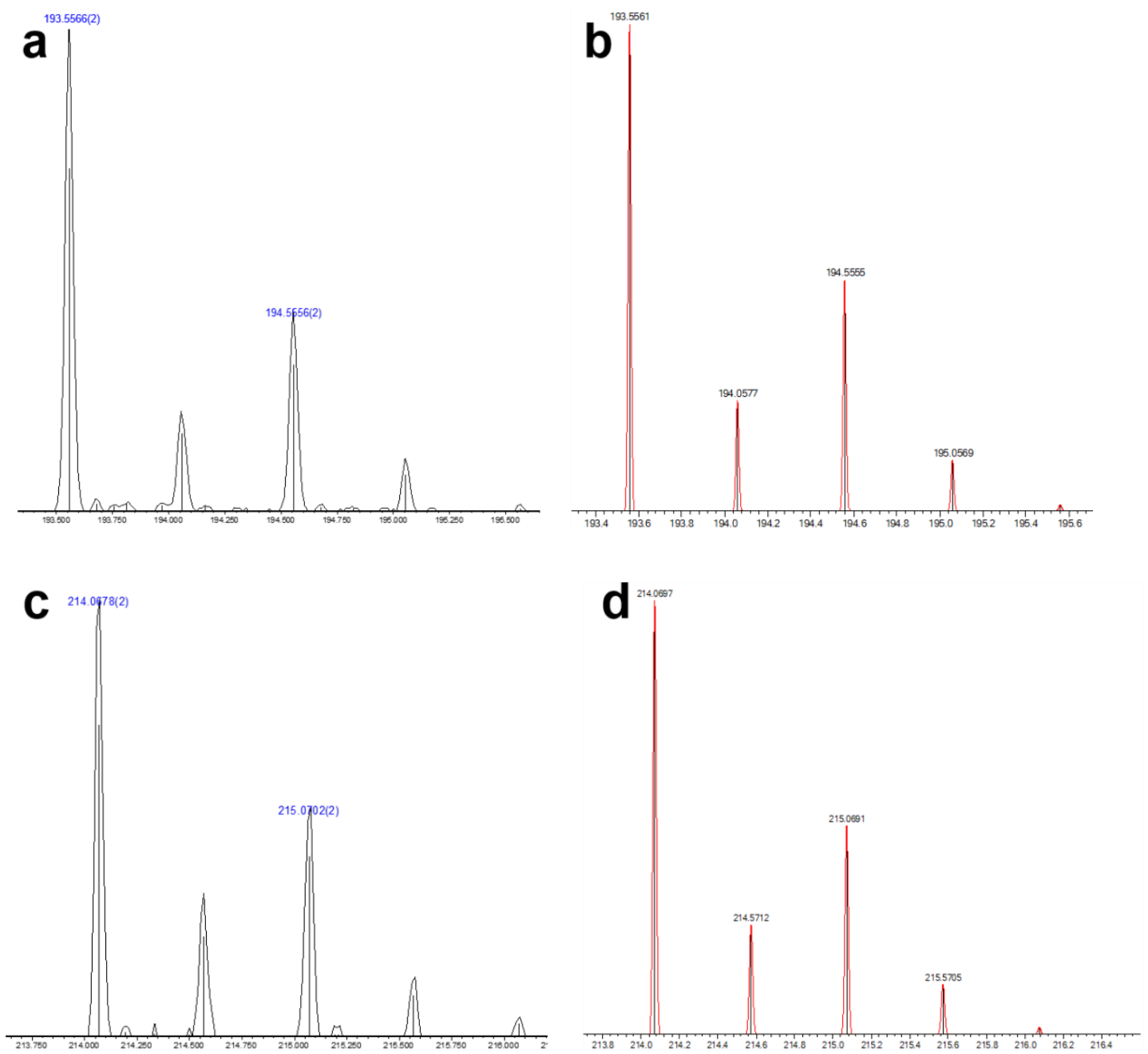

Figure S14 | Enlarged ESI-HRMS spectra of the experimental (a, c) and calculated $(\mathbf{b}, \mathbf{d}) \mathrm{m} / \mathrm{z}$ values of $\left[\mathrm{F}-\mathrm{N}_{2} \mathrm{O}_{2} \mathrm{Cu}\right](\mathrm{OTf})_{2}$ in $\mathrm{MeCN}$. 
Section 4: Spectroscopic Characterization
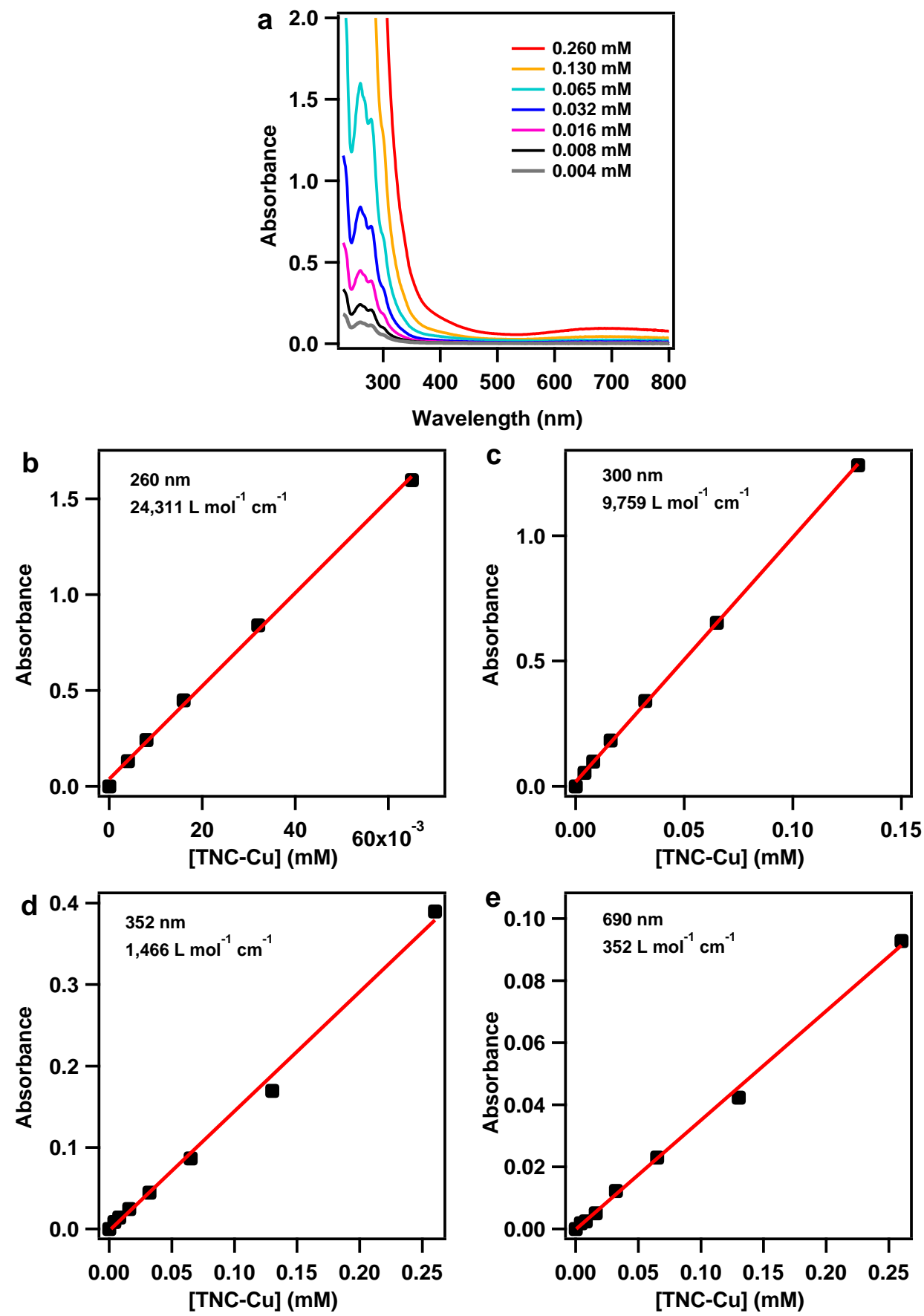

Figure S15 | (a) The UV-vis spectra of TNC-Cu at different catalyst concentrations ([TNC-Cu]) in water; (b-e) Plot of the absorbance at 260, 300, 352 and $690 \mathrm{~nm}$ versus $[\mathrm{TNC}-\mathrm{Cu}]$ in water, respectively. 


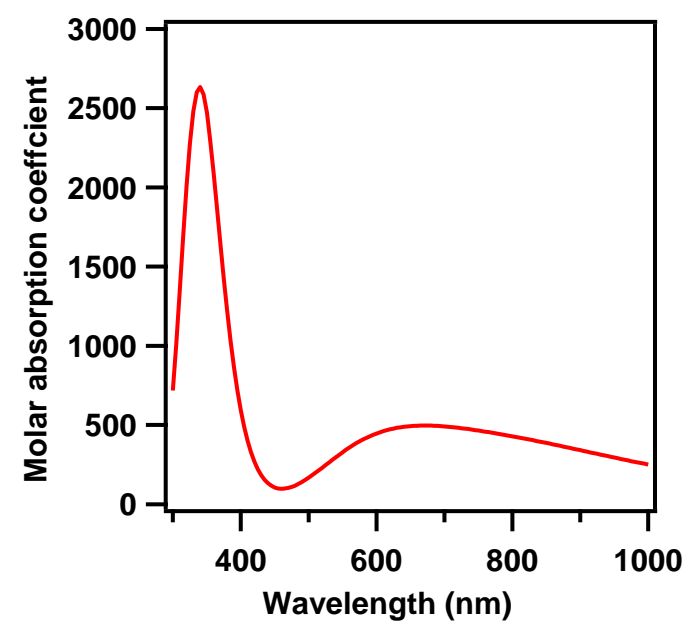

Figure S16 | UV-vis spectra of TNC-Cu calculated at the TD-B3LYP-D3 level in the aqueous solution.

Table S1 | Calculated two main electronic transitions.

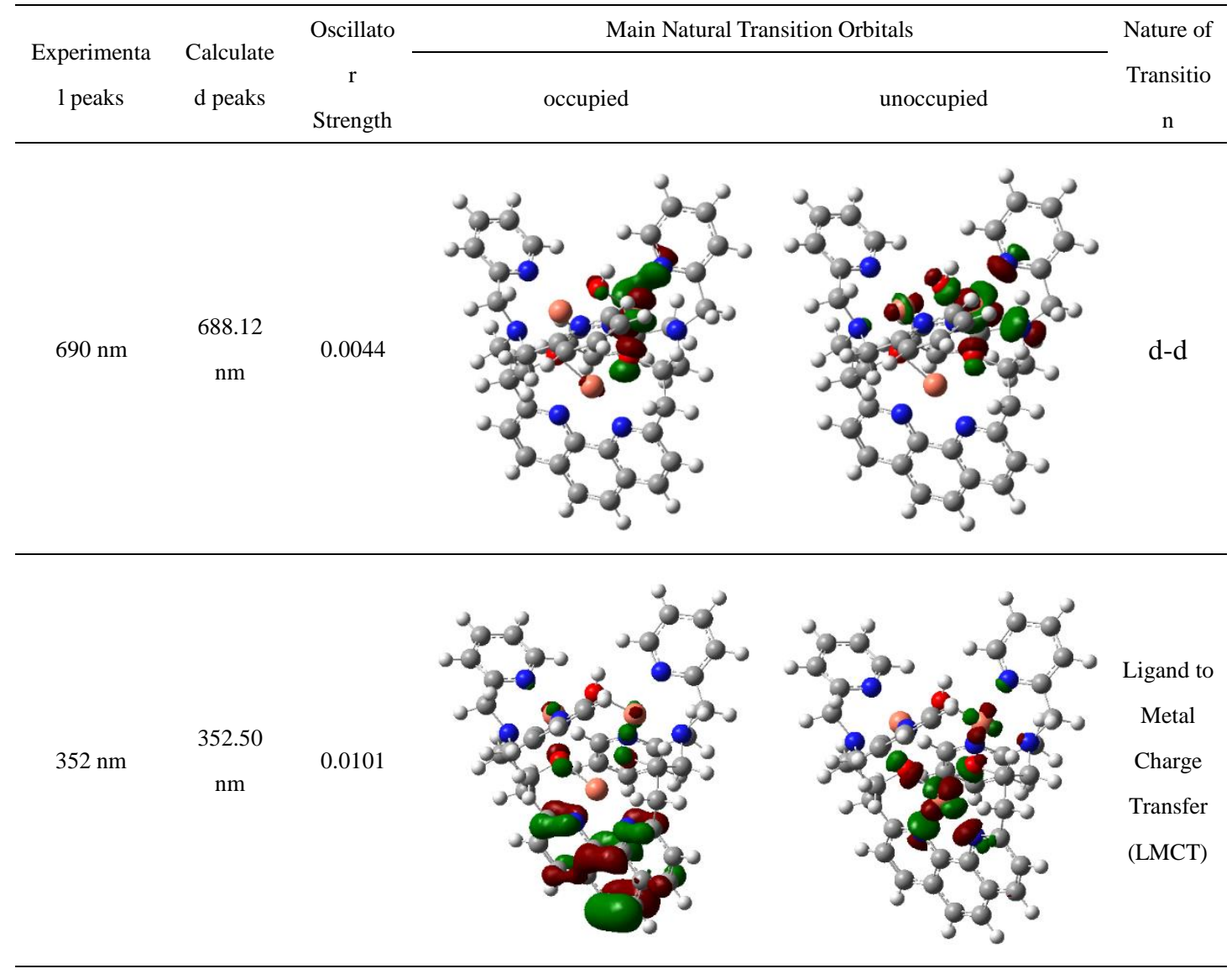




\section{Section 5: Single-Crystal Structure}

\subsection{Single-crystal structure of TNC-Cu}

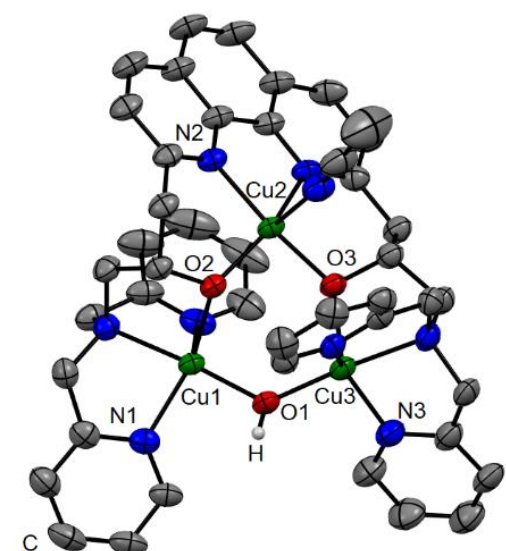

Figure S17 | Crystal structure of $\left[\left(\operatorname{app}^{2-}\right) \mathrm{Cu}_{3}(\mu-\mathrm{OH})\right]^{3+}(\mathrm{CCDC}: 1974082)$. Selected bond distances $[\AA]$ and angles $\left[{ }^{\circ}\right]$ : $\mathrm{Cu} 1-\mathrm{O} 1$ 1.890(3), Cu1-O2 1.973(3), Cu1-N1 2.017(4), Cu2-O2 1.956(3), Cu2-O3 1.905(3), Cu2-N2 1.985(4), Cu3-O1 1.897(3), Cu3-O3 2.092(3), Cu3-N3 2.059(4). Cu1-O1-Cu3 129.24(2), Cu1-O2-Cu2 125.01(2), O2-Cu2-O3 95.54(1), Cu2-O3-Cu3 124.79(2), O3-Cu3-O1 99.36(1).

Table S2 | The crystallographic data of TNC-Cu.

\begin{tabular}{|c|c|}
\hline Identification code & $\mathrm{TNC}-\mathrm{Cu}$ \\
\hline Empirical formula & $\mathrm{C}_{47} \mathrm{H}_{44} \mathrm{Cu}_{3} \mathrm{~F}_{9} \mathrm{~N}_{9} \mathrm{O}_{12} \mathrm{~S}_{3}$ \\
\hline Formula weight & 1384.71 \\
\hline Temperature/K & 107.55 \\
\hline Crystal system & triclinic \\
\hline Space group & P-1 \\
\hline Unit cell dimensions & $\begin{array}{l}\mathrm{a}=12.2473(3) \AA ; \alpha=96.746(2) \mathrm{deg} \\
\mathrm{b}=16.0179(4) \AA ; \beta=95.872(2) \mathrm{deg} \\
\mathrm{c}=16.3407(4) \AA ; \gamma=102.401(2) \mathrm{deg}\end{array}$ \\
\hline Volume $/ \AA^{3}$ & $3082.19(13)$ \\
\hline Z & 2 \\
\hline$\rho_{\text {calc }} \mathrm{g} / \mathrm{cm}^{3}$ & 1.492 \\
\hline$\mu / \mathrm{mm}^{-1}$ & 2.937 \\
\hline $\mathrm{F}(000)$ & 1402.0 \\
\hline Crystal size $/ \mathrm{mm}^{3}$ & $0.05 \times 0.04 \times 0.03$ \\
\hline Radiation & $\mathrm{Cu} \mathrm{K} \alpha(\lambda=1.54178)$ \\
\hline $2 \Theta$ range for data collection ${ }^{\circ}$ & 7.334 to 142.852 \\
\hline Index ranges & $-13 \leq \mathrm{h} \leq 15,-19 \leq \mathrm{k} \leq 17,-17 \leq 1 \leq 20$ \\
\hline Reflections collected & 21690 \\
\hline Independent reflections & $11613\left[\mathrm{R}_{\mathrm{int}}=0.0342, \mathrm{R}_{\mathrm{sigma}}=0.0439\right]$ \\
\hline Data/restraints/parameters & $11613 / 539 / 1040$ \\
\hline Goodness-of-fit on $\mathrm{F}^{2}$ & 1.038 \\
\hline Final $R$ indexes $[I>=2 \sigma(I)]$ & $\mathrm{R}_{1}=0.0709, \mathrm{wR}_{2}=0.2049$ \\
\hline Final $\mathrm{R}$ indexes [all data] & $\mathrm{R}_{1}=0.0813, \mathrm{wR}_{2}=0.2175$ \\
\hline Largest diff. peak/hole / e $\AA^{-3}$ & $1.94 /-0.88$ \\
\hline
\end{tabular}




\subsection{Single-crystal structure of HappCu2}

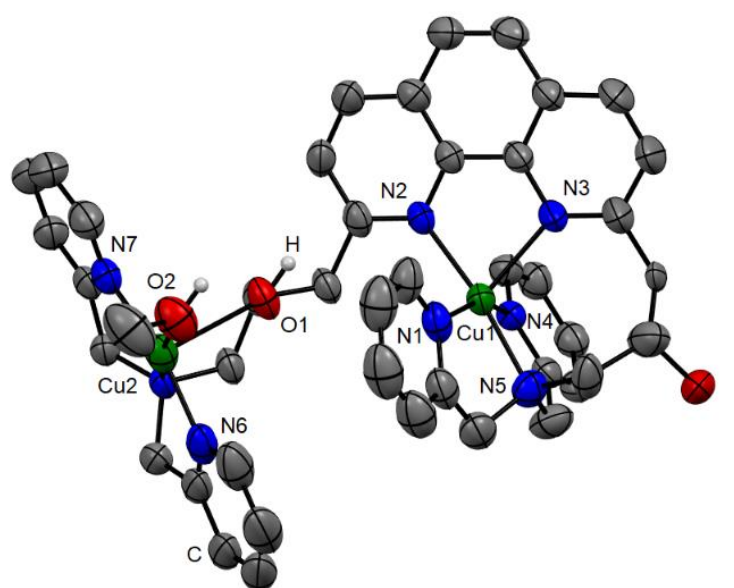

Figure S18 | Crystal structure of [(Happ $\left.) \mathrm{Cu}_{2}\right]^{3+}(\mathrm{CCDC}: 2083395)$. Selected bond distances $[\AA]$ and angles $\left[{ }^{\circ}\right]$ : Cu1-N1 2.007(5), Cu1-N2 2.016(4), Cu1-N3 2.224(4), Cu1-N4 2.002(4), Cu1-N5 2.029(4), Cu2-N6 1.974(5), Cu1-N7 1.975(5), Cu2-O1 2.388(3), Cu2-O2 1.986(5). N1-Cu1-N2 94.33(2), N2-Cu1-N3 79.96(2), N3-Cu1N4 98.17(2), N4-Cu1-N5 82.78(2), N6-Cu2-O1 96.61(2), N6-Cu2-O2 95.9(2), N6Cu2-N7 164.6(2).

Table S3 | The crystallographic data of $\mathrm{HappCu}_{2}$.

\begin{tabular}{|c|c|}
\hline Identification code & $\mathrm{HappCu}_{2}$ \\
\hline Empirical formula & $\mathrm{C}_{46} \mathrm{H}_{45} \mathrm{Cu}_{2} \mathrm{~F}_{9} \mathrm{~N}_{8} \mathrm{O}_{12} \mathrm{~S}_{3}$ \\
\hline Formula weight & 1296.16 \\
\hline Temperature/K & $173.00(10)$ \\
\hline Crystal system & triclinic \\
\hline Space group & P-1 \\
\hline Unit cell dimensions & $\begin{array}{l}\mathrm{a}=11.9462(2) \AA ; \alpha=73.803(2) \mathrm{deg} \\
\mathrm{b}=12.9419(3) \AA ; \beta=84.181(2) \mathrm{deg} \\
\mathrm{c}=19.3582(4) \AA ; \gamma=87.016(2) \mathrm{deg}\end{array}$ \\
\hline Volume $/ \AA^{3}$ & $2858.42(11)$ \\
\hline $\mathrm{Z}$ & 2 \\
\hline$\rho_{\text {calc }} \mathrm{g} / \mathrm{cm}^{3}$ & 1.506 \\
\hline$\mu / \mathrm{mm}^{-1}$ & 2.766 \\
\hline $\mathrm{F}(000)$ & 1320.0 \\
\hline Crystal size $/ \mathrm{mm}^{3}$ & $0.22 \times 0.2 \times 0.18$ \\
\hline Radiation & $\mathrm{Cu} \mathrm{K} \alpha(\lambda=1.54178)$ \\
\hline $2 \Theta$ range for data collection ${ }^{\circ}$ & 7.114 to 130.052 \\
\hline Index ranges & $-14 \leq \mathrm{h} \leq 14,-14 \leq \mathrm{k} \leq 15,-22 \leq 1 \leq 22$ \\
\hline Reflections collected & 88083 \\
\hline Independent reflections & $9644\left[\mathrm{R}_{\text {int }}=0.0526, \mathrm{R}_{\text {sigma }}=0.0227\right]$ \\
\hline Data/restraints/parameters & $9644 / 78 / 738$ \\
\hline Goodness-of-fit on $\mathrm{F}^{2}$ & 1.020 \\
\hline Final $R$ indexes $[\mathrm{I}>=2 \sigma(\mathrm{I})]$ & $\mathrm{R}_{1}=0.0753, \mathrm{wR}_{2}=0.2039$ \\
\hline Final R indexes [all data] & $\mathrm{R}_{1}=0.0884, \mathrm{wR}_{2}=0.2188$ \\
\hline Largest diff. peak/hole / e $\AA^{-3}$ & $1.27 /-0.73$ \\
\hline
\end{tabular}




\subsection{Single-crystal structure of $\mathrm{F}-\mathrm{N}_{2} \mathrm{O}_{2} \mathrm{Cu}$}

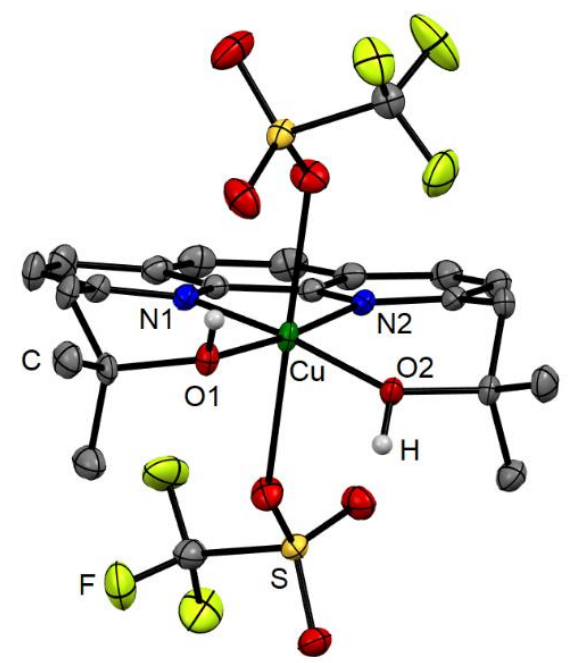

Figure S19 | Crystal structure of [F- $\left.\mathrm{N}_{2} \mathrm{O}_{2} \mathrm{Cu}\right](\mathrm{OTf})_{2}$ (CCDC: 2083394). Selected bond distances $[\AA]$ and angles $\left[{ }^{\circ}\right]$ : $\mathrm{Cu}-\mathrm{O} 1$ 1.791(2), $\mathrm{Cu}-\mathrm{O} 2$ 1.965(4), Cu-N1 1.978(2), CuN2 1.949(4). O1-Cu-O2 90.73(6), O1-Cu-N1 93.58(7), N1-Cu-N2 83.54(7), N2$\mathrm{Cu}-\mathrm{O} 2$ 92.77(7).

Table S4 The crystallographic data of $\left[\mathrm{F}-\mathrm{N}_{2} \mathrm{O}_{2} \mathrm{Cu}\right](\mathrm{OTf})_{2}$.

\begin{tabular}{|c|c|}
\hline Identification code & $\mathrm{F}-\mathrm{N}_{2} \mathrm{O}_{2} \mathrm{Cu}$ \\
\hline Empirical formula & $\mathrm{C}_{22} \mathrm{H}_{24} \mathrm{CuF}_{6} \mathrm{~N}_{2} \mathrm{O}_{8} \mathrm{~S}_{2}$ \\
\hline Formula weight & 686.09 \\
\hline Temperature/K & $173.00(10)$ \\
\hline Crystal system & monoclinic \\
\hline Space group & $\mathrm{P} 2_{1} / \mathrm{c}$ \\
\hline Unit cell dimensions & $\begin{array}{l}\mathrm{a}=15.3500(3) \AA ; \alpha=90 \mathrm{deg} . \\
\mathrm{b}=11.7588(2) \AA ; \beta=113.332(2) \mathrm{deg} . \\
\mathrm{c}=16.0478(3) \AA ; \gamma=90 \mathrm{deg} .\end{array}$ \\
\hline Volume $/ \AA^{3}$ & $2659.72(9)$ \\
\hline Z & 4 \\
\hline$\rho_{\text {calc }} \mathrm{g} / \mathrm{cm}^{3}$ & 1.713 \\
\hline$\mu / \mathrm{mm}^{-1}$ & 3.485 \\
\hline $\mathrm{F}(000)$ & 1396.0 \\
\hline Crystal size $/ \mathrm{mm}^{3}$ & $0.5 \times 0.4 \times 0.4$ \\
\hline Radiation & $\mathrm{Cu} \mathrm{K} \alpha(\lambda=1.54184)$ \\
\hline $2 \Theta$ range for data collection ${ }^{\circ}$ & 9.622 to 130.124 \\
\hline $\begin{array}{l}\text { Index ranges } \\
\text { Reflections collected }\end{array}$ & $\begin{array}{l}-15 \leq \mathrm{h} \leq 18,-13 \leq \mathrm{k} \leq 10,-16 \leq 1 \leq 18 \\
9852\end{array}$ \\
\hline Independent reflections & $4434\left[\mathrm{R}_{\text {int }}=0.0228, \mathrm{R}_{\text {sigma }}=0.0265\right]$ \\
\hline Data/restraints/parameters & $4434 / 6 / 380$ \\
\hline Goodness-of-fit on $\mathrm{F}^{2}$ & 1.101 \\
\hline Final $R$ indexes $[\mathrm{I}>=2 \sigma(\mathrm{I})]$ & $\mathrm{R}_{1}=0.0331, \mathrm{wR}_{2}=0.0875$ \\
\hline Final $\mathrm{R}$ indexes [all data] & $\mathrm{R}_{1}=0.0351, \mathrm{wR}_{2}=0.0887$ \\
\hline Largest diff. peak/hole / e $\AA^{-3}$ & $0.32 /-0.80$ \\
\hline
\end{tabular}




\section{Section 6: Evidence for Homogeneous Catalysis}

\subsection{CPE at 1.64 V:}
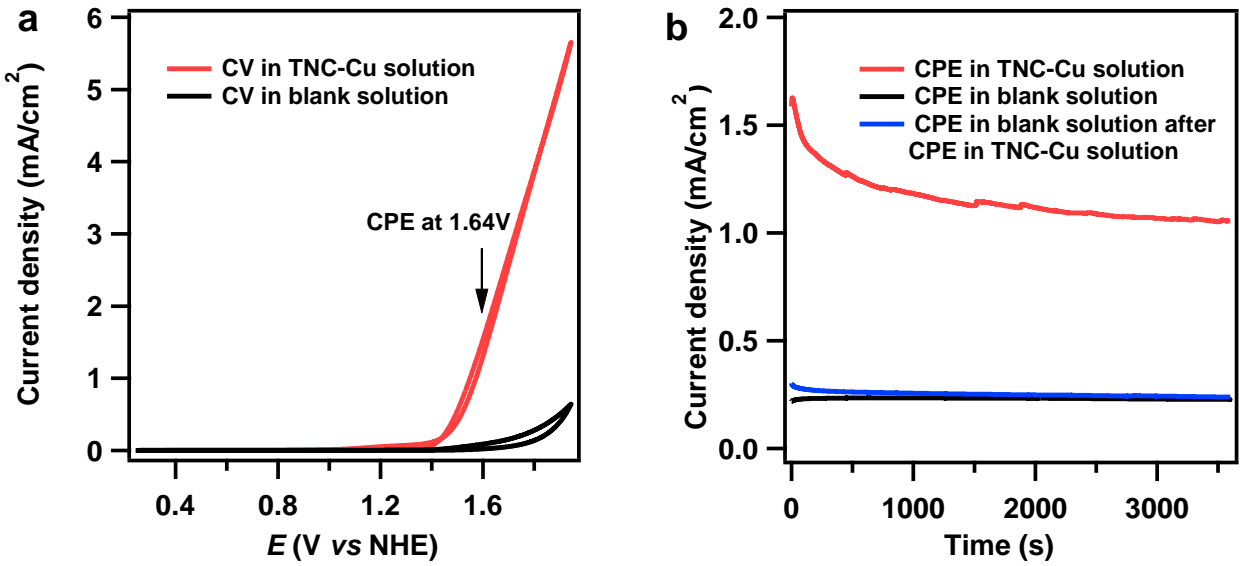

Figure $\mathbf{S 2 0} \mid$ (a) CV of TNC-Cu $(1 \mathrm{mM})$ with FTO $\left(1 \mathrm{~cm}^{2}\right)$ in aqueous $\mathrm{NaHCO}_{3}(1 \mathrm{M}$, pH 8.4); scan rate: $100 \mathrm{mV} \mathrm{s}^{-1}$; (b) CPEs at $1.64 \mathrm{~V}$ in aqueous $\mathrm{NaHCO}_{3}(1 \mathrm{M}, \mathrm{pH} 8.4)$ without (black) and with (red) TNC-Cu $\left(1 \mathrm{mM}, \mathrm{Cu}_{3}\right)$ using FTO as the working electrode. The blue line represents the CPE of the used FTO after CPE (1 h duration) in the presence of catalyst, then the used FTO was rinsed with deionized water and transferred into aqueous $\mathrm{NaHCO}_{3}(1 \mathrm{M}, \mathrm{pH} 8.4)$ without catalyst.
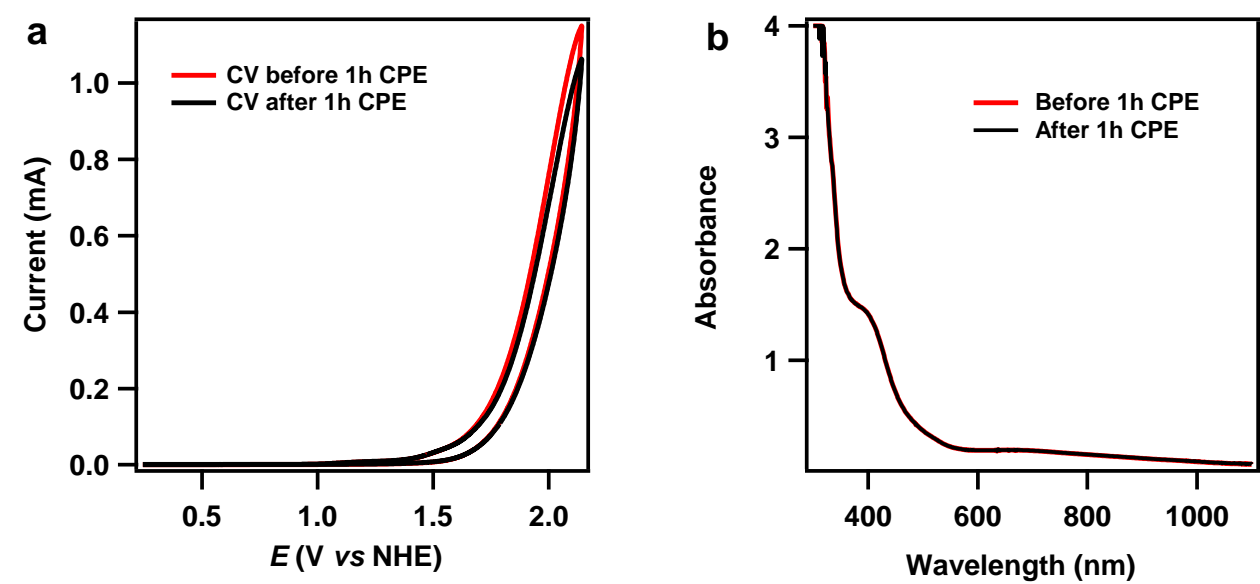

Figure S21 | (a) CV of TNC-Cu (1 mM) in aqueous $\mathrm{NaHCO}_{3}(1 \mathrm{M}, \mathrm{pH} 8.4)$ before (red line) and after (black) CPE for $1 \mathrm{~h}$; scan rate: $100 \mathrm{mV} \mathrm{s}^{-1}$. Working electrode: BDD; reference electrode: saturated calomel electrode (SCE); (b) UV-vis spectrum of TNC-Cu $(0.5 \mathrm{mM})$ in aqueous $\mathrm{NaHCO}_{3}(1 \mathrm{M}, \mathrm{pH} 8.4)$ before (red) and after (black) $\mathrm{CPE}$ for $1 \mathrm{~h}$.

The FTO electrode tested over $1 \mathrm{~h} \mathrm{CPE}$ at $1.64 \mathrm{~V}$ in $\mathrm{NaHCO}_{3}$ solution containing TNC-Cu $(1 \mathrm{mM})$ was taken out from the catalyst solution. No change in colour of the electrode surface was observed. Then, the FTO was rinsed with deionized water and showed no current increase during CPE in blank solution without catalyst. The above results indicated that no active copper oxide formed on the FTO surface. For the catalyst solution after $1 \mathrm{~h} \mathrm{CPE}$, the catalytic current in the CV and UV-vis spectra were 
almost the same as those for the catalyst solution before $1 \mathrm{~h} \mathrm{CPE}$, which indicates that TNC-Cu is stable after $1 \mathrm{~h} \mathrm{CPE}$ and responsible for catalysing water oxidation.
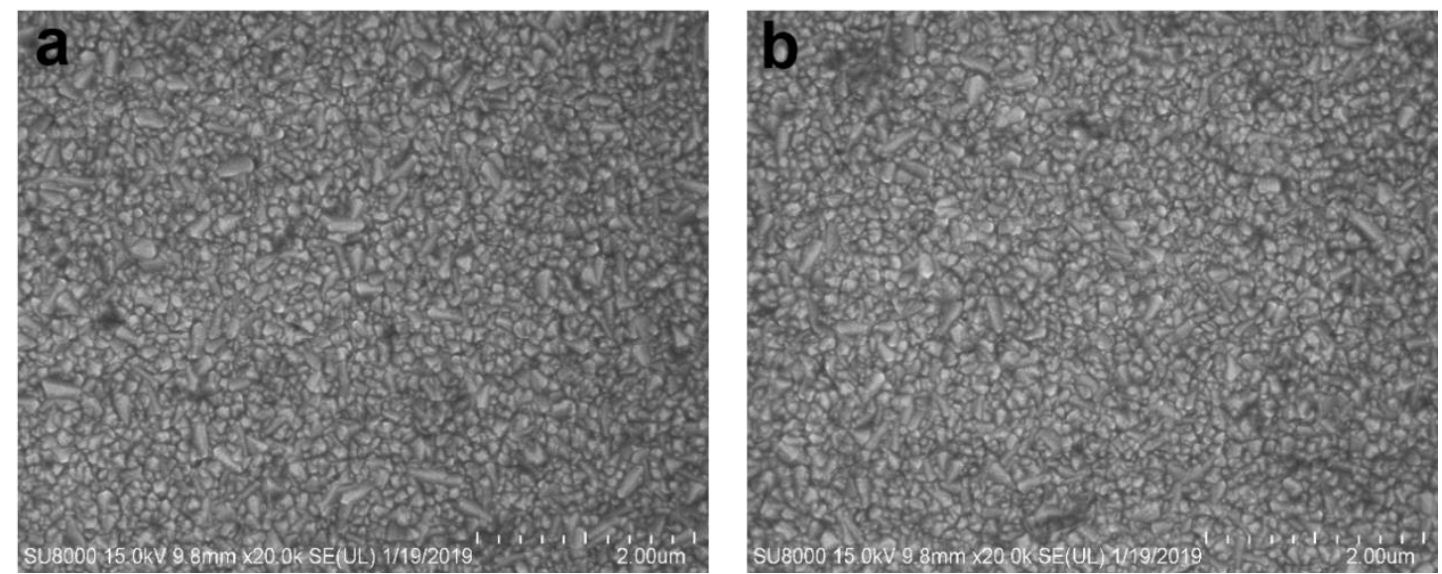

Figure S22 | SEM image of the FTO electrode before (a) and after (b) CPE of TNC-Cu $(1 \mathrm{mM})$ at $1.64 \mathrm{~V}$ in aqueous $\mathrm{NaHCO}_{3}(1 \mathrm{M}, \mathrm{pH} 8.4)$ for $1 \mathrm{~h}$. There was no $\mathrm{CuO}_{x}$ deposited on the FTO electrode after CPE.

SEM images of the FTO before and after $1 \mathrm{~h} \mathrm{CPE}$ at $1.64 \mathrm{~V}$ in $\mathrm{NaHCO}_{3}$ solution containing TNC-Cu $(1 \mathrm{mM})$ showed no differences in morphology, which indicated that no copper oxide particles formed on the FTO. In addition, no copper signal was observed on the FTO after $1 \mathrm{~h}$ CPE according to the EDX and XPS analysis.
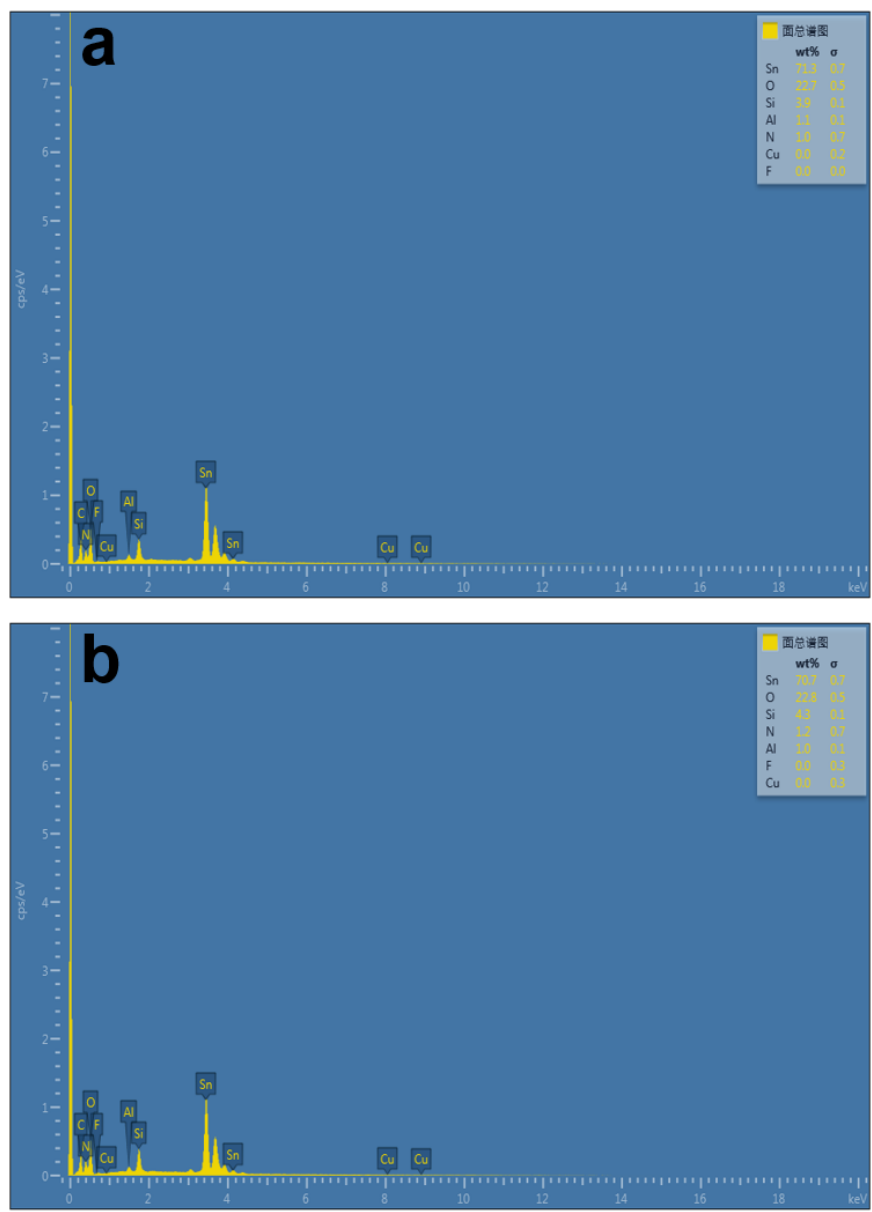
Figure S23 | EDX analysis of the FTO electrode before (a) and after (b) CPE of TNC-Cu $(1 \mathrm{mM})$ at $1.64 \mathrm{~V}$ in aqueous $\mathrm{NaHCO}_{3}(1 \mathrm{M}, \mathrm{pH} 8.4)$ for $1 \mathrm{~h}$. No $\mathrm{Cu}$ was detected on the FTO electrode after CPE.
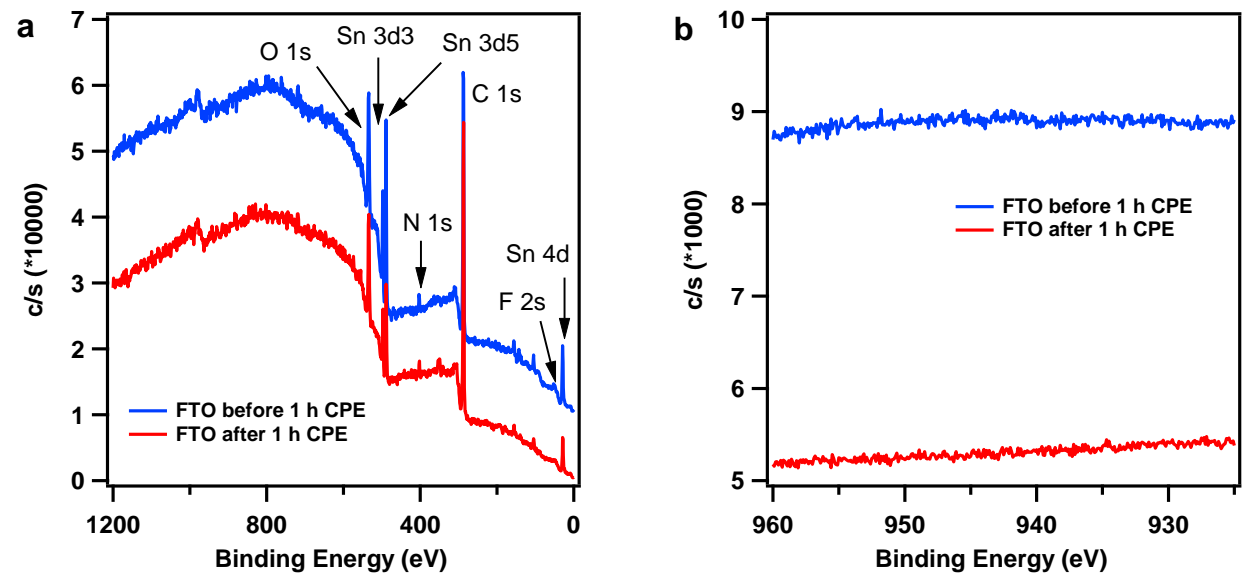

Figure S24 | (a) XPS analysis of the FTO electrode before (blue line) and after (red) CPE of TNC-Cu $(1 \mathrm{mM})$ at $1.64 \mathrm{~V}$ in aqueous $\mathrm{NaHCO}_{3}(1 \mathrm{M}, \mathrm{pH} 8.4)$ for $1 \mathrm{~h}$; (b) XPS in the region of 920 to $960 \mathrm{eV}$ for the FTO electrode before (blue) and after (red) CPE.

\subsection{CPE at 2.14 V:}
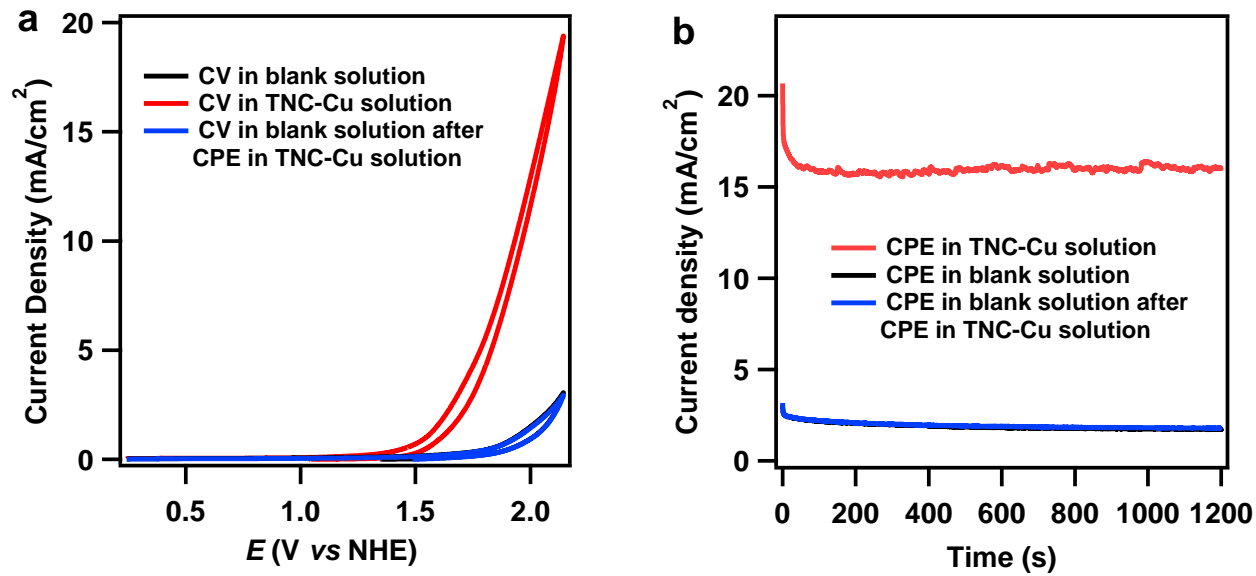

Figure S25 | (a) CV of TNC-Cu (1 mM) with BDD plate $\left(0.5 \mathrm{~cm}^{2}\right)$ in aqueous $\mathrm{NaHCO}_{3}(1 \mathrm{M}, \mathrm{pH} 8.4)$; scan rate: $100 \mathrm{mV} \mathrm{s}^{-1}$. The blue line represents the $\mathrm{CV}$ of the used BDD plate after CPE $(1,200 \mathrm{~s}$ duration) at $2.14 \mathrm{~V}$ in the presence of catalyst, then the BDD was rinsed with deionized water and transferred into aqueous $\mathrm{NaHCO}_{3}$ ( $1 \mathrm{M}, \mathrm{pH}$ 8.4) without catalyst; (b) CPEs at $2.14 \mathrm{~V}$ in aqueous $\mathrm{NaHCO}_{3}(1 \mathrm{M}, \mathrm{pH} 8.4)$ without (black line) and with (red) TNC-Cu $\left(1 \mathrm{mM}, \mathrm{Cu}_{3}\right)$ using BDD plate $\left(0.5 \mathrm{~cm}^{2}\right)$ as the working electrode. The blue line represents the CPE of the used BDD plate after CPE (1,200 s duration) in the presence of catalyst, then the BDD was rinsed with deionized water and transferred into aqueous $\mathrm{NaHCO}_{3}(1 \mathrm{M}, \mathrm{pH}$ 8.4) without catalyst. 


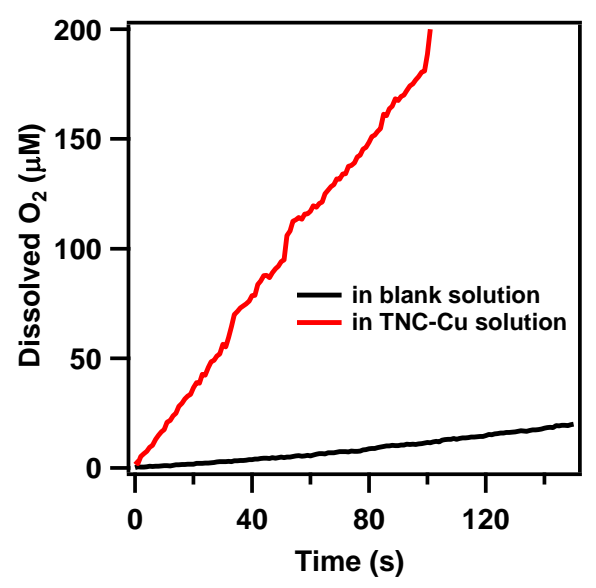

Figure S26 | $\mathrm{O}_{2}$ evolution during controlled potential electrolysis without (black line) and with TNC-Cu (1 mM; red), as measured with a calibrated Ocean Optics FOXY fluorescent probe. Applied potential: $2.14 \mathrm{~V}$ vs NHE. Working electrode: $0.5 \mathrm{~cm}^{2}$ BDD plate electrode.
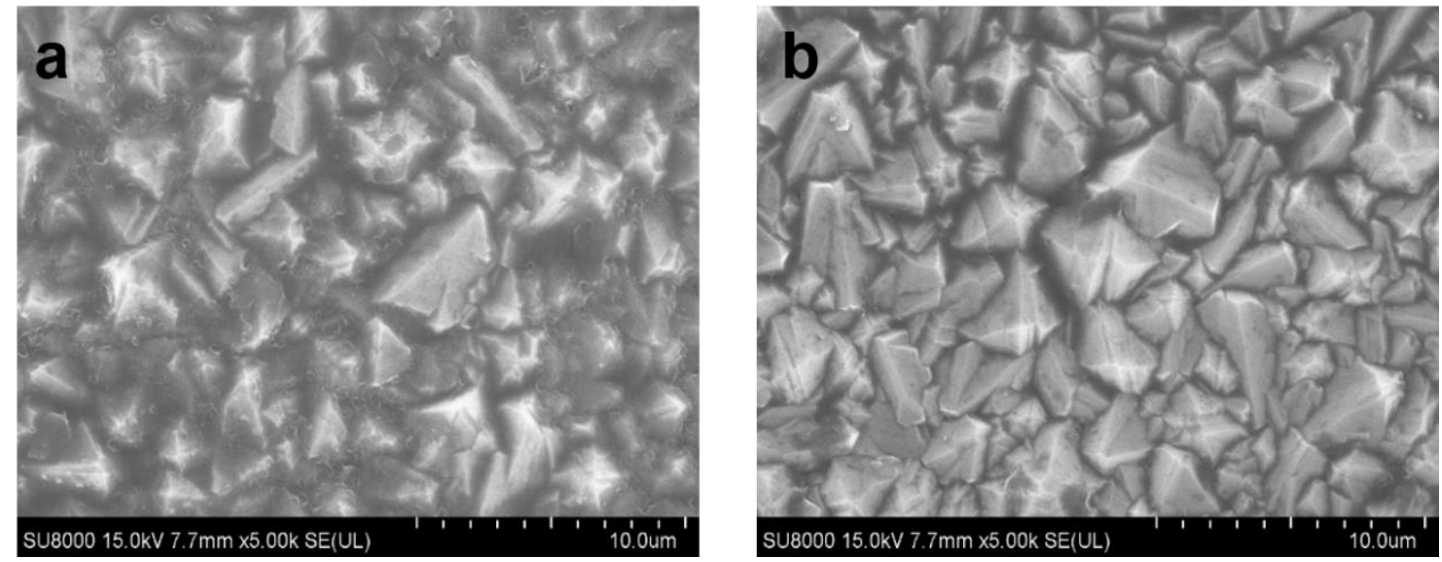

Figure S27 | SEM image of the BDD plate electrode before (a) and after (b) CPE of TNC-Cu $(1 \mathrm{mM})$ at $2.14 \mathrm{~V}$ in aqueous $\mathrm{NaHCO}_{3}(1 \mathrm{M}, \mathrm{pH} 8.4)$ for $1,200 \mathrm{~s}$. There was no $\mathrm{CuO}_{x}$ deposited on the BDD plate electrode after CPE.

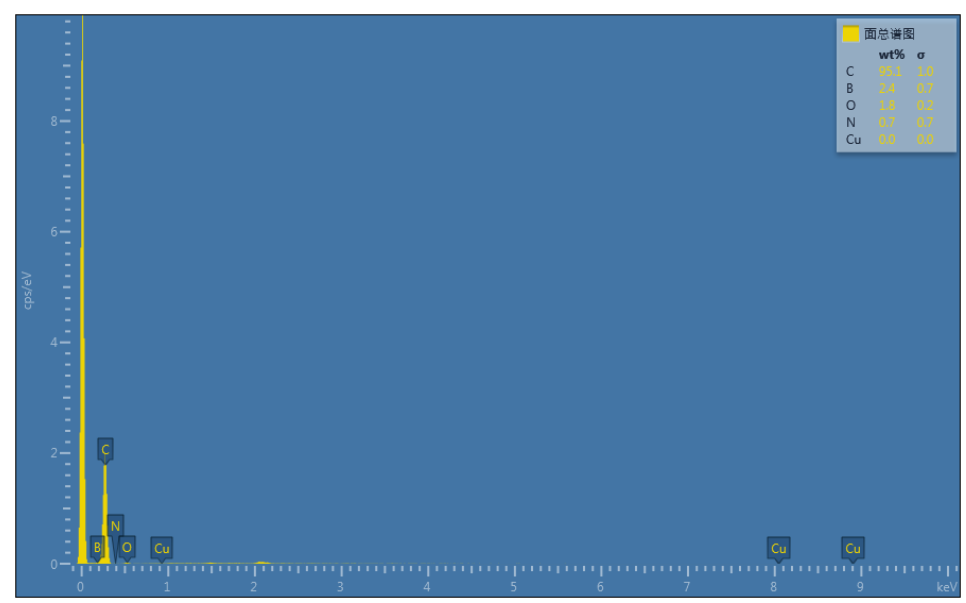

Figure S28 EDX analysis of the BDD plate electrode after CPE of TNC-Cu (1 mM) at $2.14 \mathrm{~V}$ in aqueous $\mathrm{NaHCO}_{3}(1 \mathrm{M}, \mathrm{pH} 8.4)$ for 1,200 s. No Cu was detected on the BDD plate electrode after CPE. 

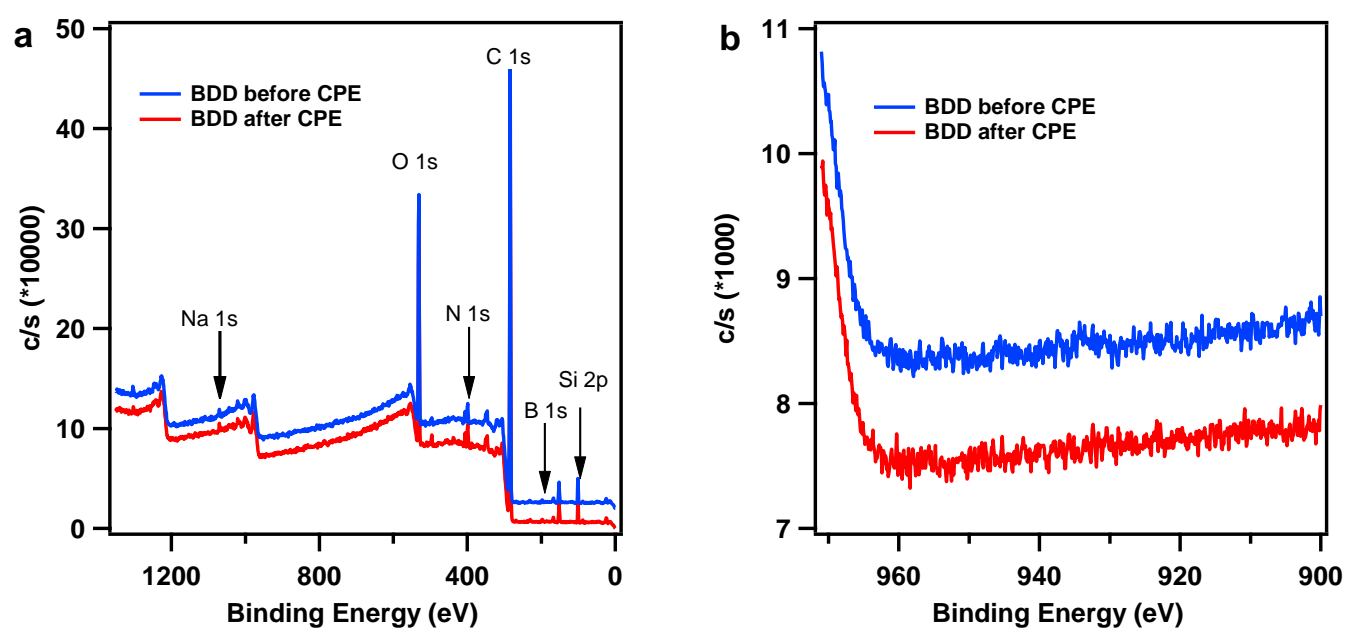

Figure S29 | (a) XPS analysis of the BDD plate electrode before (blue line) and after (red) CPE of TNC-Cu (1 mM) at $2.14 \mathrm{~V}$ in aqueous $\mathrm{NaHCO}_{3}(1 \mathrm{M}, \mathrm{pH} 8.4)$ for $1,200 \mathrm{~s}$; (b) XPS in the region of 900 to $970 \mathrm{eV}$ for the BDD plate electrode before (blue) and after (red) CPE. 


\section{Section 7: Electrochemical Properties}

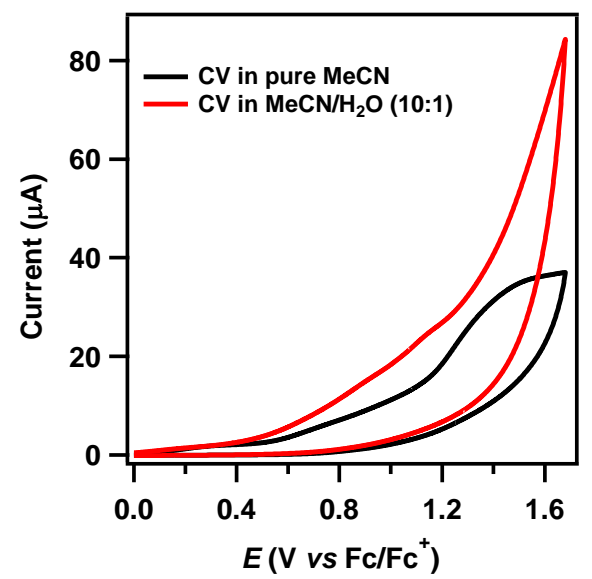

Figure S30 | CV with positive scan of $\mathrm{TNC}-\mathrm{Cu}(1 \mathrm{mM})$ in anhydrous $\mathrm{MeCN}$ containing $\mathrm{TBAPF}_{6}(0.1 \mathrm{M})$ as the supporting electrolyte. Working electrode: BDD; reference electrode: $\mathrm{Ag} / \mathrm{AgNO}_{3}$. Scan rate: $100 \mathrm{mV} \mathrm{s}^{-1}$.

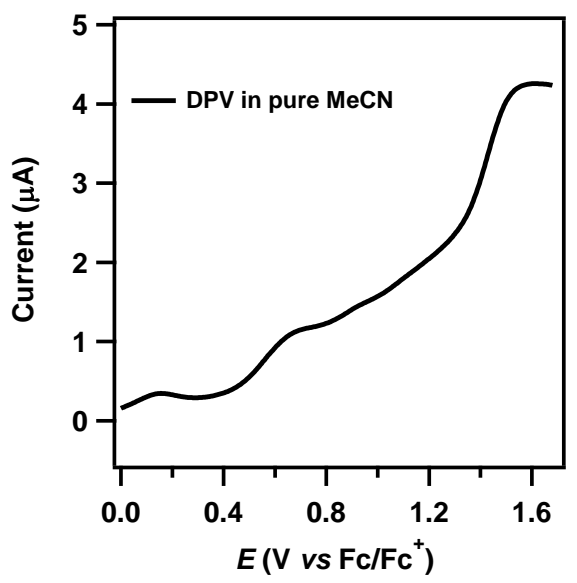

Figure S31 | Differential pulse voltammetry (DPV) with positive scan of TNC-Cu (1 $\mathrm{mM})$ in anhydrous $\mathrm{MeCN}$ containing $\mathrm{TBAPF}_{6}(0.1 \mathrm{M})$ as the supporting electrolyte. Working electrode: $\mathrm{BDD}$; reference electrode: $\mathrm{Ag} / \mathrm{AgNO}_{3}$.

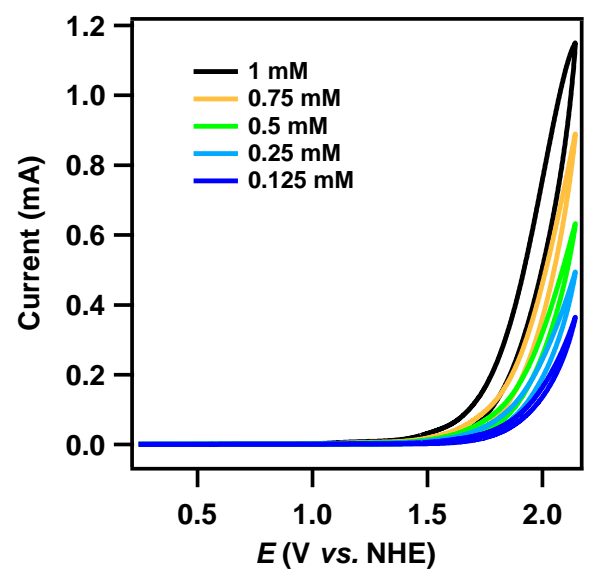


Figure S32 | CV for different concentrations of TNC-Cu in aqueous $\mathrm{NaHCO}_{3}(1 \mathrm{M}$, $\mathrm{pH}$ 8.4). Working electrode: BDD. Scan rate: $100 \mathrm{mV} \mathrm{s}^{-1}$.
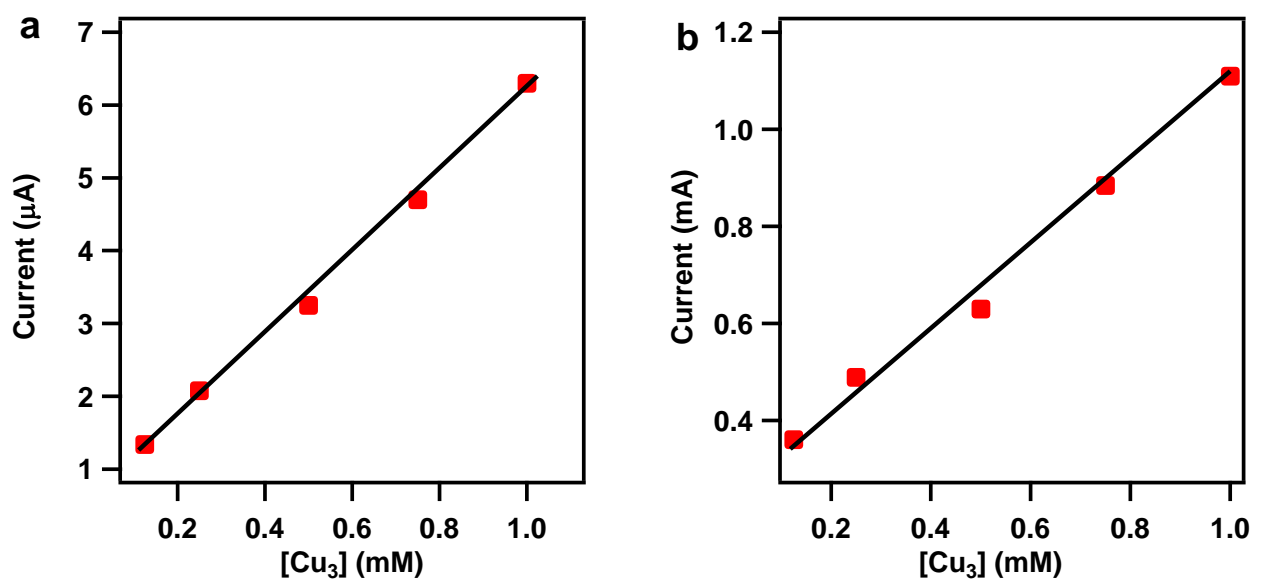

Figure S33 | (a) Plot of the diffusion current $i_{\mathrm{d}}$ at $\sim 1.2 \mathrm{~V}$ versus catalyst concentration ([Cu 3$])$; (b) Plot of the catalytic current $i_{\text {cat }}$ at $\sim 2.14 \mathrm{~V}$ versus $\left[\mathrm{Cu}_{3}\right]$.
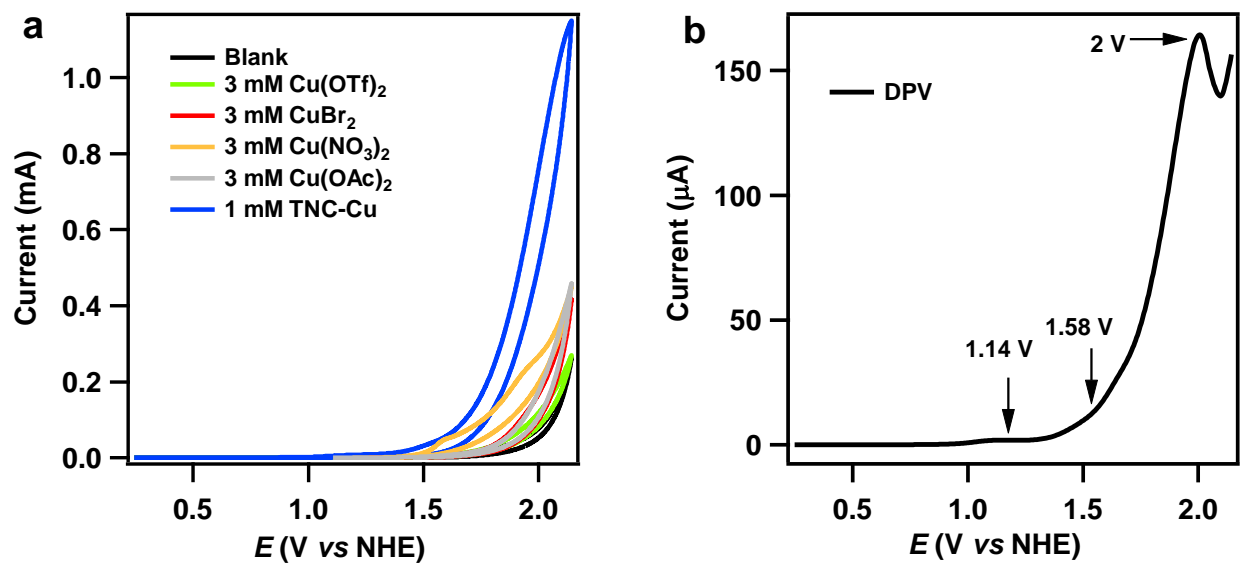

Figure S34 | (a) CV of aqueous $\mathrm{NaHCO}_{3}$ (1 M, pH 8.4) alone (black line), and containing TNC-Cu (1 mM; blue) or various kinds of simple copper salts $(3 \mathrm{mM})$. Scan rate: $100 \mathrm{mV} \mathrm{s}^{-1}$. Working electrode: BDD; counter electrode: Pt; reference electrode: saturated calomel electrode (SCE); (b) DPV of TNC-Cu (1 mM) in aqueous $\mathrm{NaHCO}_{3}$ (1 M, pH 8.4). Working electrode: BDD. 

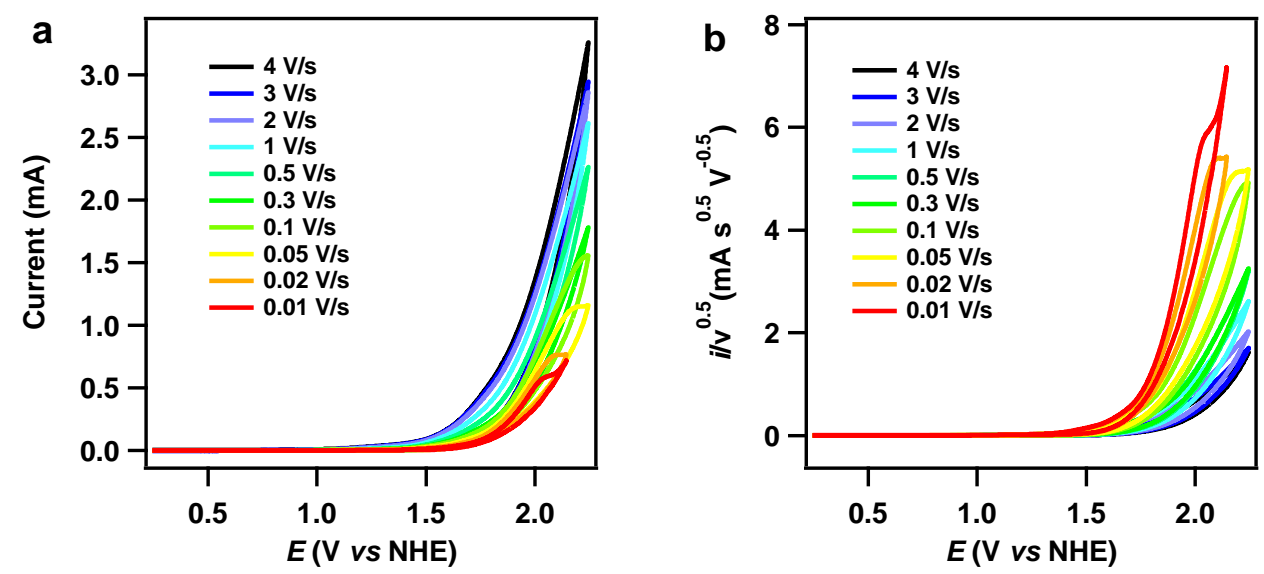

Figure S35 | (a) CV of TNC-Cu (1 mM) in aqueous $\mathrm{NaHCO}_{3}(1 \mathrm{M}, \mathrm{pH} 8.4)$ at different scan rates. Working electrode: BDD; (b) Normalized cyclic voltammograms $\left(i / v^{1 / 2}\right)$ of TNC-Cu in aqueous $\mathrm{NaHCO}_{3}(1 \mathrm{M}, \mathrm{pH} 8.4)$ at different scan rates. Working electrode: BDD.
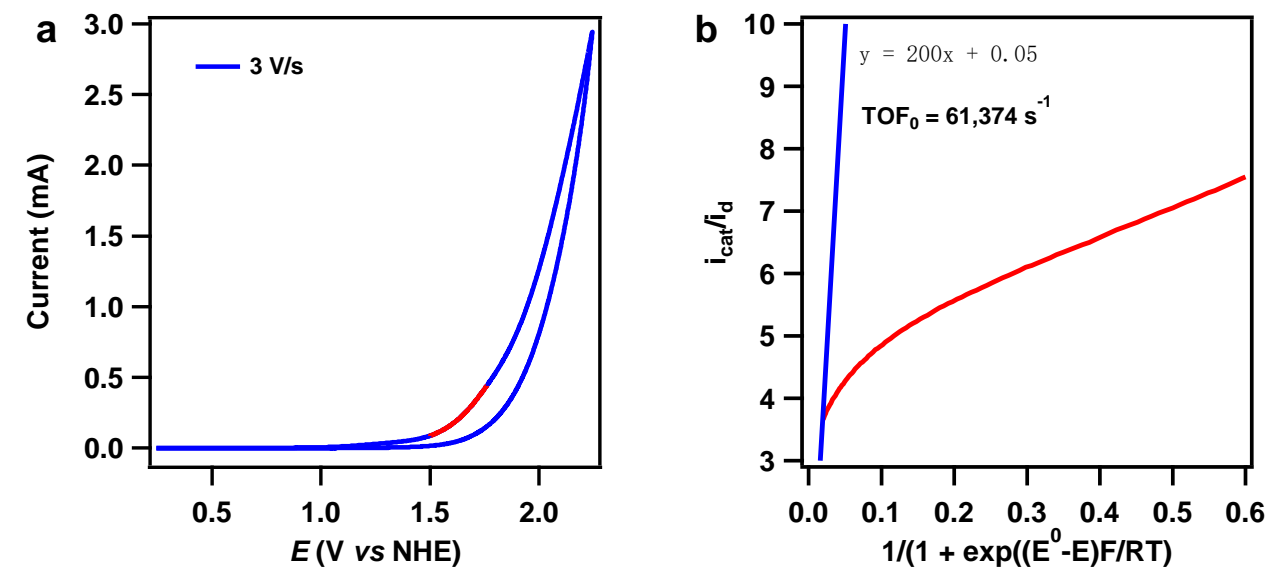

Figure S36 | CV of aqueous $\mathrm{NaHCO}_{3}(1 \mathrm{M}, \mathrm{pH} 8.4)$ containing $\mathrm{TNC}-\mathrm{Cu}(1 \mathrm{mM}$; blue). Scan rate: $3 \mathrm{~V} \mathrm{~s}^{-1}$. Working electrode: BDD; counter electrode: Pt; reference electrode: saturated calomel electrode (SCE). The red line both in (a) and (b) means the experimental data of $\mathrm{CV}$ used for Foot of Wave Analysis. The blue line in (b) represents the fitting line to calculate the $\mathrm{TOF}_{0}$ (at zero potential).
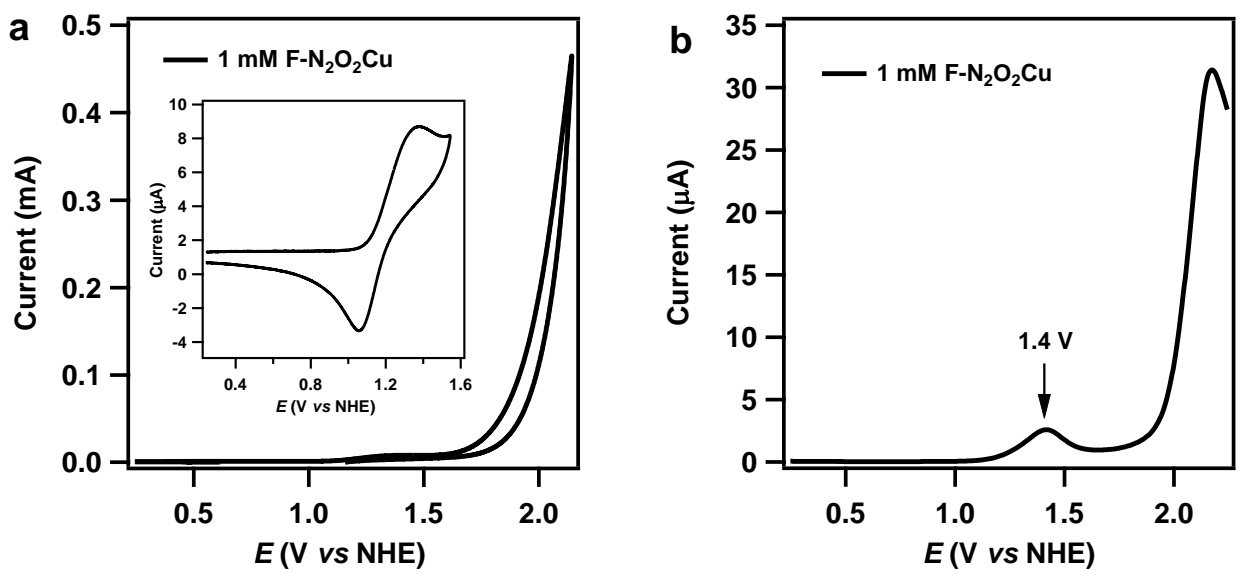

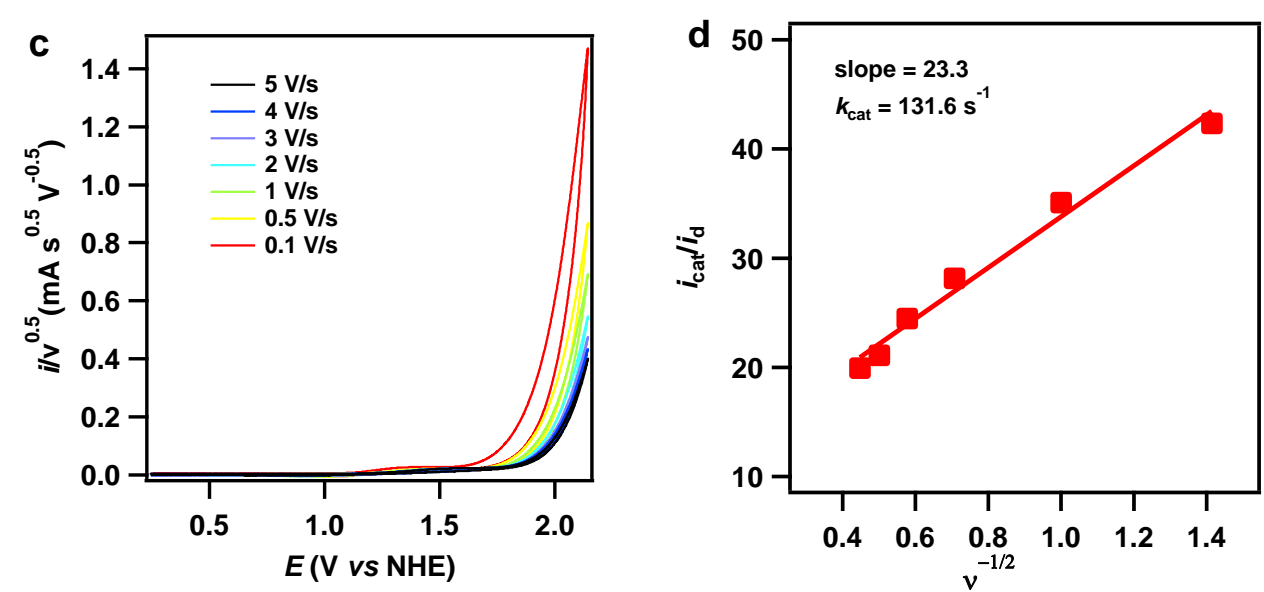

Figure S37 |CV (a) and DPV (b) of $\mathrm{F}_{-} \mathrm{N}_{2} \mathrm{O}_{2} \mathrm{Cu}(1 \mathrm{mM})$ in aqueous $\mathrm{NaHCO}_{3}(1 \mathrm{M}$, $\mathrm{pH}$ 8.4). Scan rate: $100 \mathrm{mV} \mathrm{s}^{-1}$. Working electrode: BDD; counter electrode: $\mathrm{Pt}$; reference electrode: saturated calomel electrode (SCE). Inset: The enlarged CV of F- $\mathrm{N}_{2} \mathrm{O}_{2} \mathrm{Cu}$ in aqueous $\mathrm{NaHCO}_{3}$ solution. Scan rate: $100 \mathrm{mV} \mathrm{s}^{-1}$; (c) Normalized cyclic voltammograms $\left(i / v^{1 / 2}\right)$ of $\mathrm{F}-\mathrm{N}_{2} \mathrm{O}_{2} \mathrm{Cu}$ in aqueous $\mathrm{NaHCO}_{3}(1 \mathrm{M}, \mathrm{pH} 8.4)$ at different scan rates; (d) Plot of $i_{\text {cat }} / i_{\mathrm{d}}$ versus $v^{-1 / 2}$ ( $i_{\text {cat }}$ : the catalytic current at $\sim 2.14 \mathrm{~V}, i_{\mathrm{d}}$ : the diffusion current at $\sim 1.4 \mathrm{~V}, v: 0.5-4 \mathrm{~V} \mathrm{~s}^{-1}$ ).
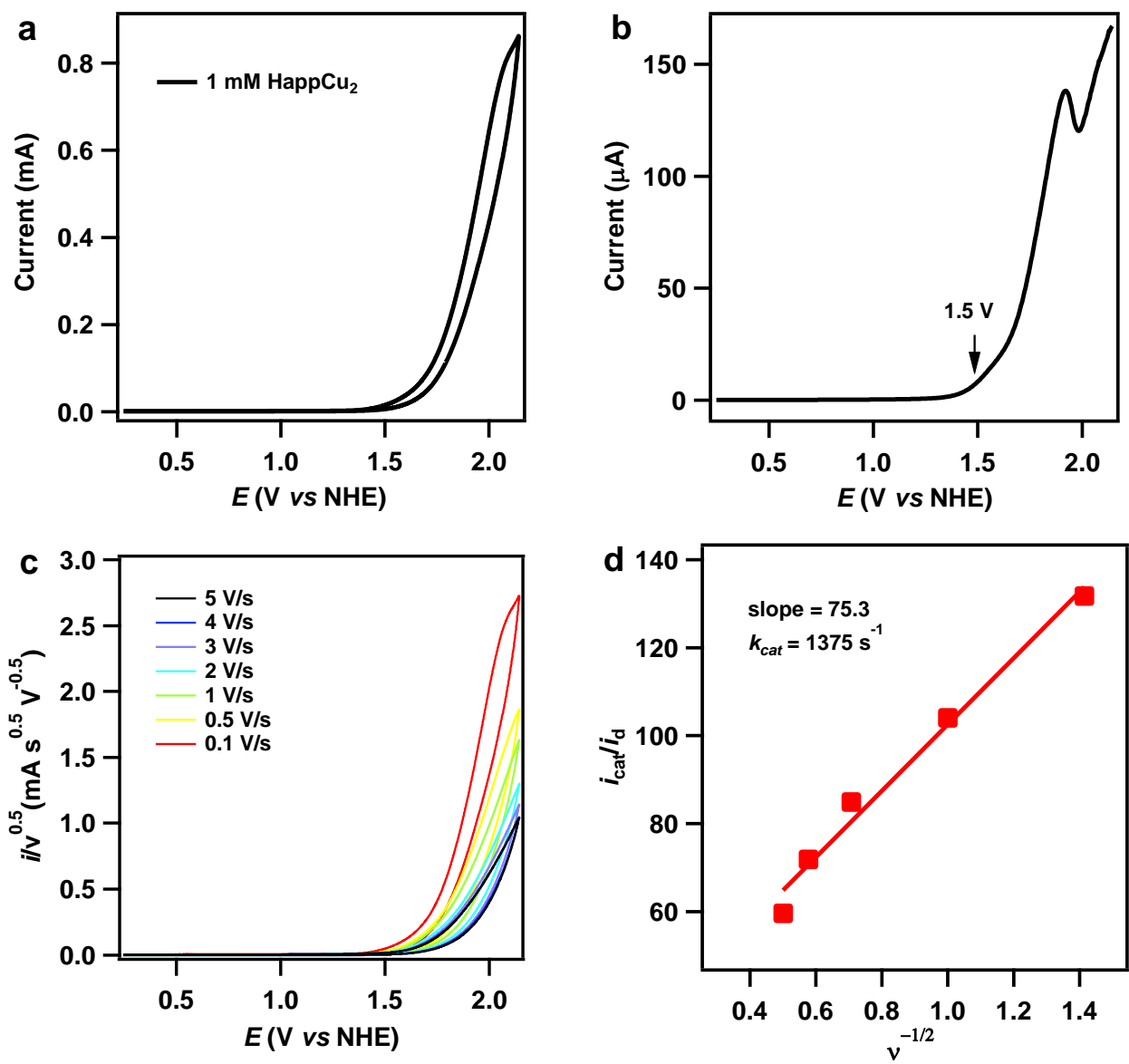

Figure $\mathbf{S 3 8} \mid \mathrm{CV}$ (a) and DPV (b) of $\mathrm{HappCu}_{2}(1 \mathrm{mM})$ in aqueous $\mathrm{NaHCO}_{3}(1 \mathrm{M}, \mathrm{pH}$ 8.4). Scan rate: $100 \mathrm{mV} \mathrm{s}^{-1}$. Working electrode: BDD; counter electrode: Pt; reference electrode: saturated calomel electrode (SCE); (c) Normalized cyclic voltammograms $\left(i / v^{1 / 2}\right)$ of $\mathrm{HappCu}_{2}$ in aqueous $\mathrm{NaHCO}_{3}(1 \mathrm{M}, \mathrm{pH} 8.4)$ at different scan rates; (d) Plot 
of $i_{\text {cat }} / i_{\mathrm{d}}$ versus $v^{-1 / 2}$ ( $i_{\text {cat: }}$ the catalytic current at $\sim 2.14 \mathrm{~V}, i_{\mathrm{d}}$ : the diffusion current at $\left.\sim 1.5 \mathrm{~V}, v: 0.5-4 \mathrm{~V} \mathrm{~s}^{-1}\right)$.
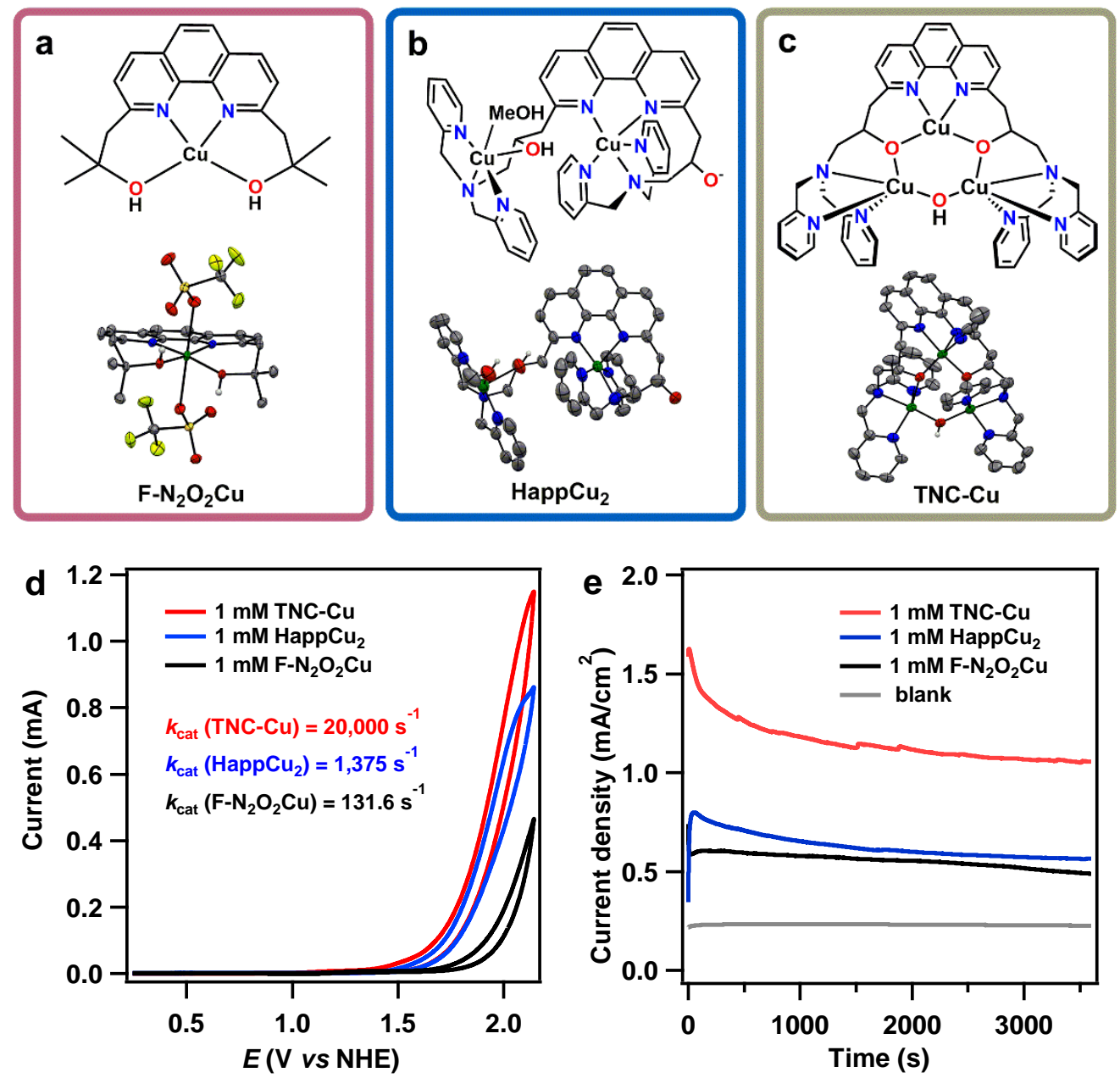

Figure S39 | The crystal structures of $\mathrm{F}_{-} \mathrm{N}_{2} \mathrm{O}_{2} \mathrm{Cu}(\mathbf{a}), \mathrm{HappCu}_{2}$ (b) and $\mathrm{TNC}-\mathrm{Cu}$ (c); (d) $\mathrm{CV}$ of aqueous $\mathrm{NaHCO}_{3}\left(1 \mathrm{M}, \mathrm{pH}\right.$ 8.4) containing TNC-Cu (1 mM; red), HappCu $\mathrm{Hu}_{2}(1$ $\mathrm{mM}$; blue), and $\mathrm{F}-\mathrm{N}_{2} \mathrm{O}_{2} \mathrm{Cu}$ (1 $\mathrm{mM}$, black), respectively. Scan rate: $100 \mathrm{mV} \mathrm{s}^{-1}$. Working electrode: BDD; counter electrode: Pt; reference electrode: saturated calomel electrode (SCE); (e) $\mathrm{CPE}$ at $1.64 \mathrm{~V}$ of aqueous $\mathrm{NaHCO}_{3}(1 \mathrm{M}, \mathrm{pH}$ 8.4) containing TNC-Cu (1 mM; red), HappCu $\mathrm{H}_{2}\left(1 \mathrm{mM}\right.$; blue), and $\mathrm{F}_{-} \mathrm{N}_{2} \mathrm{O}_{2} \mathrm{Cu}(1 \mathrm{mM}$, black) and without catalyst (grey), respectively. Working electrode: FTO $\left(1 \mathrm{~cm}^{2}\right)$; counter electrode: Pt; reference electrode: saturated calomel electrode (SCE). 


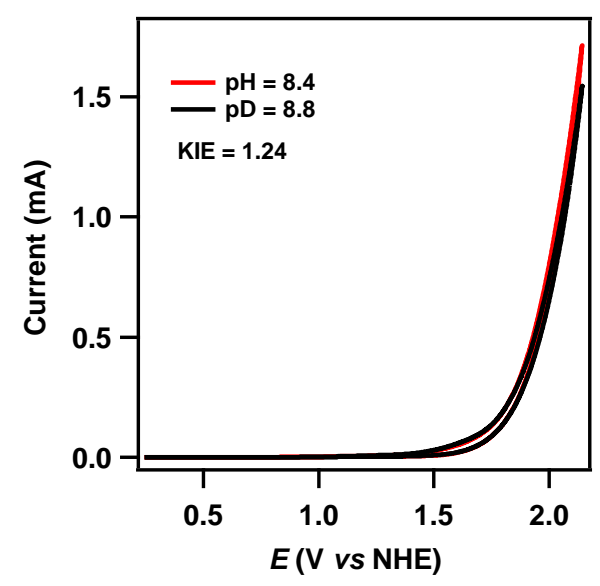

Figure $\mathbf{S 4 0} \mid \mathrm{CV}$ of TNC-Cu $(1 \mathrm{mM})$ in aqueous $\mathrm{NaHCO}_{3}(1 \mathrm{M}, \mathrm{pH} 8.4$, red line) and $\mathrm{NaDCO}_{3}$ (1 M, pD 8.8, black). Working electrode: BDD. Scan rate: $100 \mathrm{mV} \mathrm{s}^{-1}$.
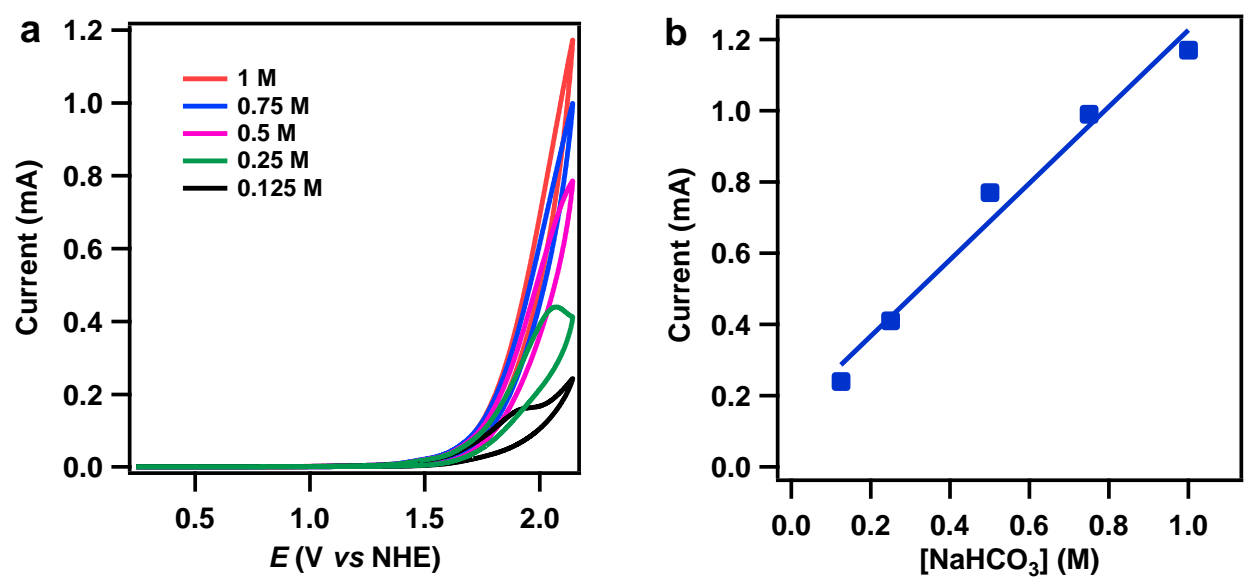

Figure S41 | (a) CV for TNC-Cu (1 mM) in different concentrations of aqueous $\mathrm{NaHCO}_{3}(\mathrm{pH} 8.4$ ) solution. The ionic strengths of the tested solutions were maintained at $1 \mathrm{M}$ by $\mathrm{NaNO}_{3}$. Working electrode: BDD. Scan rate: $100 \mathrm{mV} \mathrm{s}^{-1}$; (b) Plot of the catalytic current $i_{\text {cat }}$ at $\sim 2.14 \mathrm{~V}$ versus $\mathrm{NaHCO}_{3}$ concentration $\left(\left[\mathrm{NaHCO}_{3}\right]\right)$.
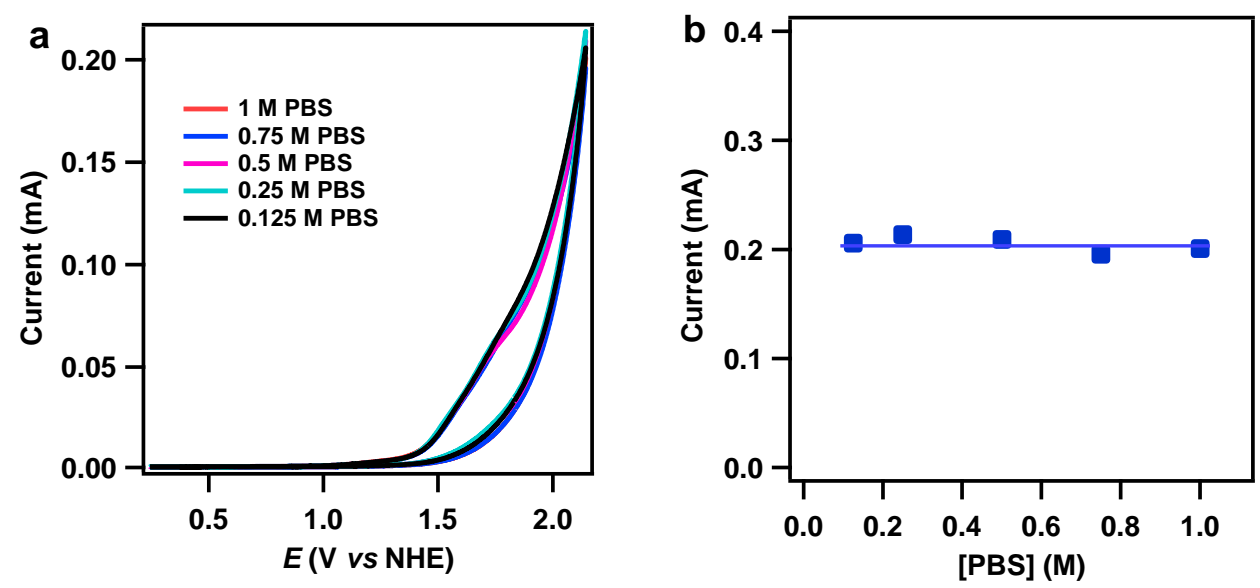
Figure S42 | (a) CV for TNC-Cu (1 mM) in different concentrations of phosphate buffer solution (PBS, $\mathrm{pH}$ 8.4). Working electrode: BDD. Scan rate: $100 \mathrm{mV} \mathrm{s}^{-1}$; (b) Plot of the catalytic current $i_{\text {cat }}$ at $\sim 2.14 \mathrm{~V}$ versus PBS concentration ([PBS]).

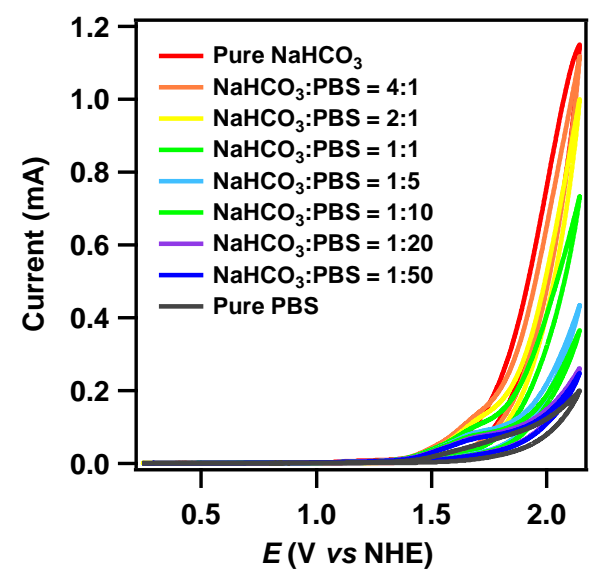

Figure $\mathbf{S 4 3} \mid \mathrm{CV}$ for TNC-Cu (1 mM) in buffer solutions (1 M, pH 8.4) with different $\mathrm{NaHCO}_{3}$ : PBS ratios. Working electrode: BDD. Scan rate: $100 \mathrm{mV} \mathrm{s}^{-1}$.
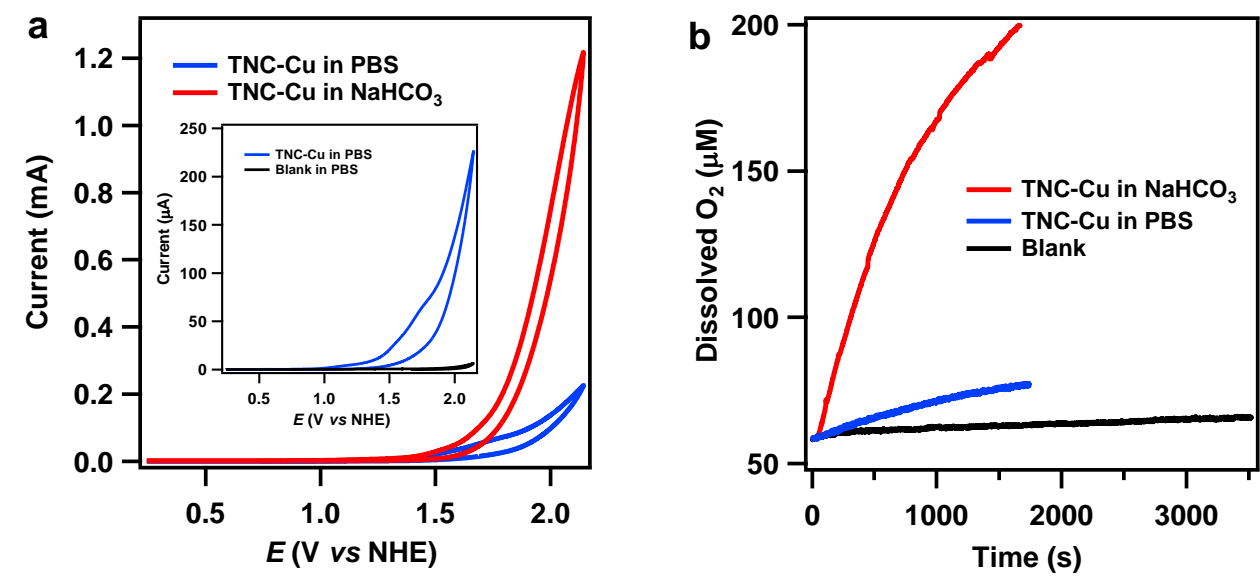

Figure S44 |(a) CV of TNC-Cu (1 mM) in phosphate buffer solution $(0.1 \mathrm{M}$, pH 7 , blue line) and in aqueous $\mathrm{NaHCO}_{3}(1 \mathrm{M}$, pH 8.4, red line). Inset: The enlarged CV of TNC-Cu $(1 \mathrm{mM})$ in phosphate buffer solution $(0.1 \mathrm{M}, \mathrm{pH} 7)$. Scan rate: $100 \mathrm{mV} \mathrm{s}^{-1}$. The black line represents the $\mathrm{CV}$ in phosphate buffer solution $(0.1 \mathrm{M}, \mathrm{pH} 7)$ without TNC-Cu. Working electrode: BDD; counter electrode: Pt; reference electrode: saturated calomel electrode (SCE); (b) The comparison of $\mathrm{O}_{2}$ evolution during controlled potential electrolysis with TNC-Cu $(1 \mathrm{mM})$ in phosphate buffer solution $\left(0.1 \mathrm{M}, \mathrm{pH} 7\right.$, blue) and in $\mathrm{NaHCO}_{3}(1 \mathrm{M}, \mathrm{pH} 8.4$, red), respectively. The black line represents $\mathrm{O}_{2}$ evolution during controlled potential electrolysis in $\mathrm{NaHCO}_{3}$ solution without catalyst. The applied potential: $1.64 \mathrm{~V}$ vs NHE. Working electrode: $1 \mathrm{~cm}^{2}$ fluorine-doped tin oxide (FTO). 
Section 8: Catalytic performance comparison of the reported $\mathrm{Cu}$-based molecular catalysts for water oxidation

Table S5 | Catalytic performance comparison between TNC-Cu in this work and the reported $\mathrm{Cu}$-based molecular catalysts for water oxidation.

\begin{tabular}{|l|l|l|l|l|l|l|}
\hline & Electrolyte & $\mathrm{pH}$ & $\mathrm{\eta}(\mathrm{V})^{\mathrm{a}}$ & $\mathrm{TOF}\left(\mathrm{s}^{-1}\right)$ & FE (\%) & Ref. \\
\hline & & & & & & \\
\hline
\end{tabular}




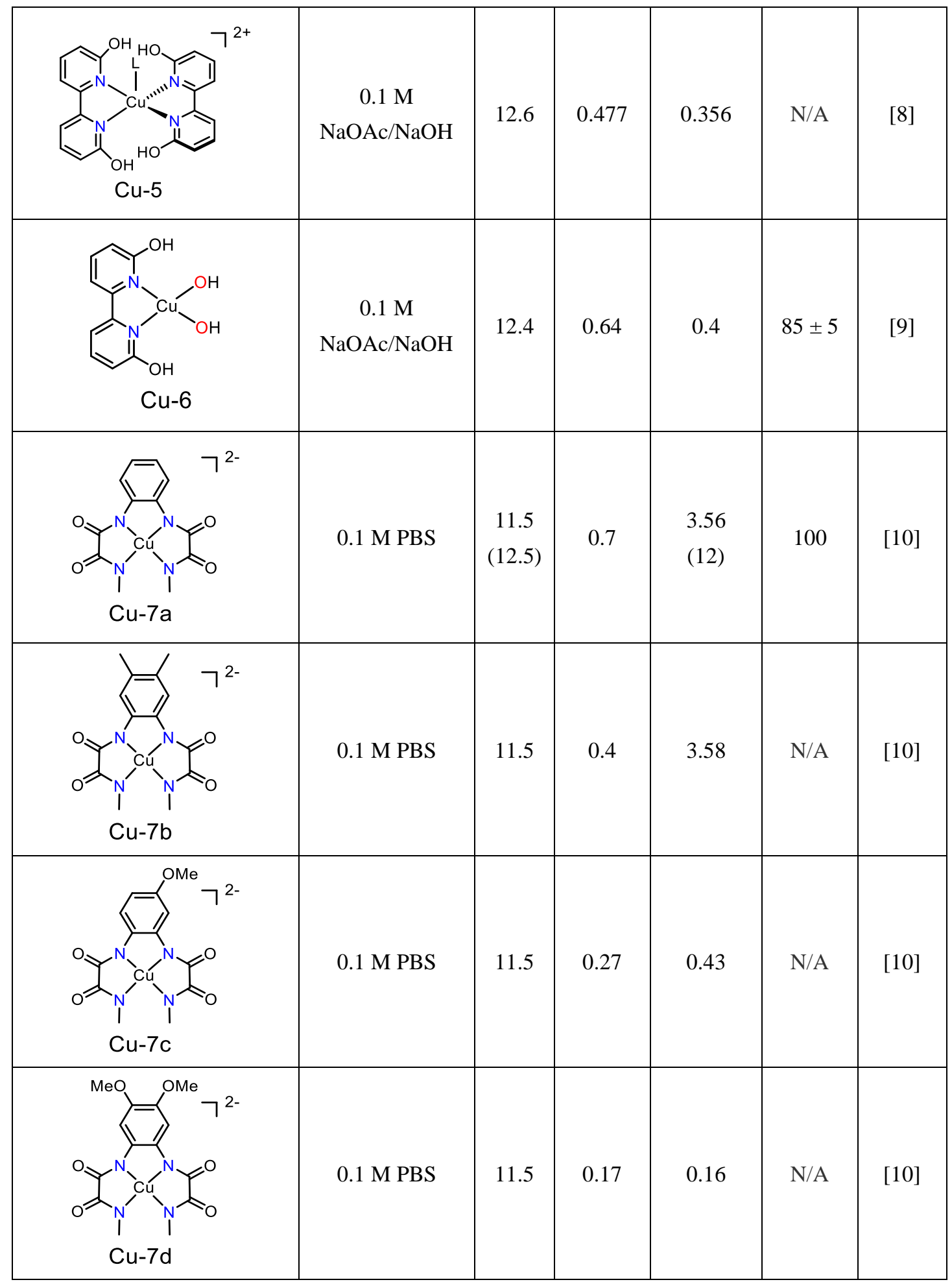




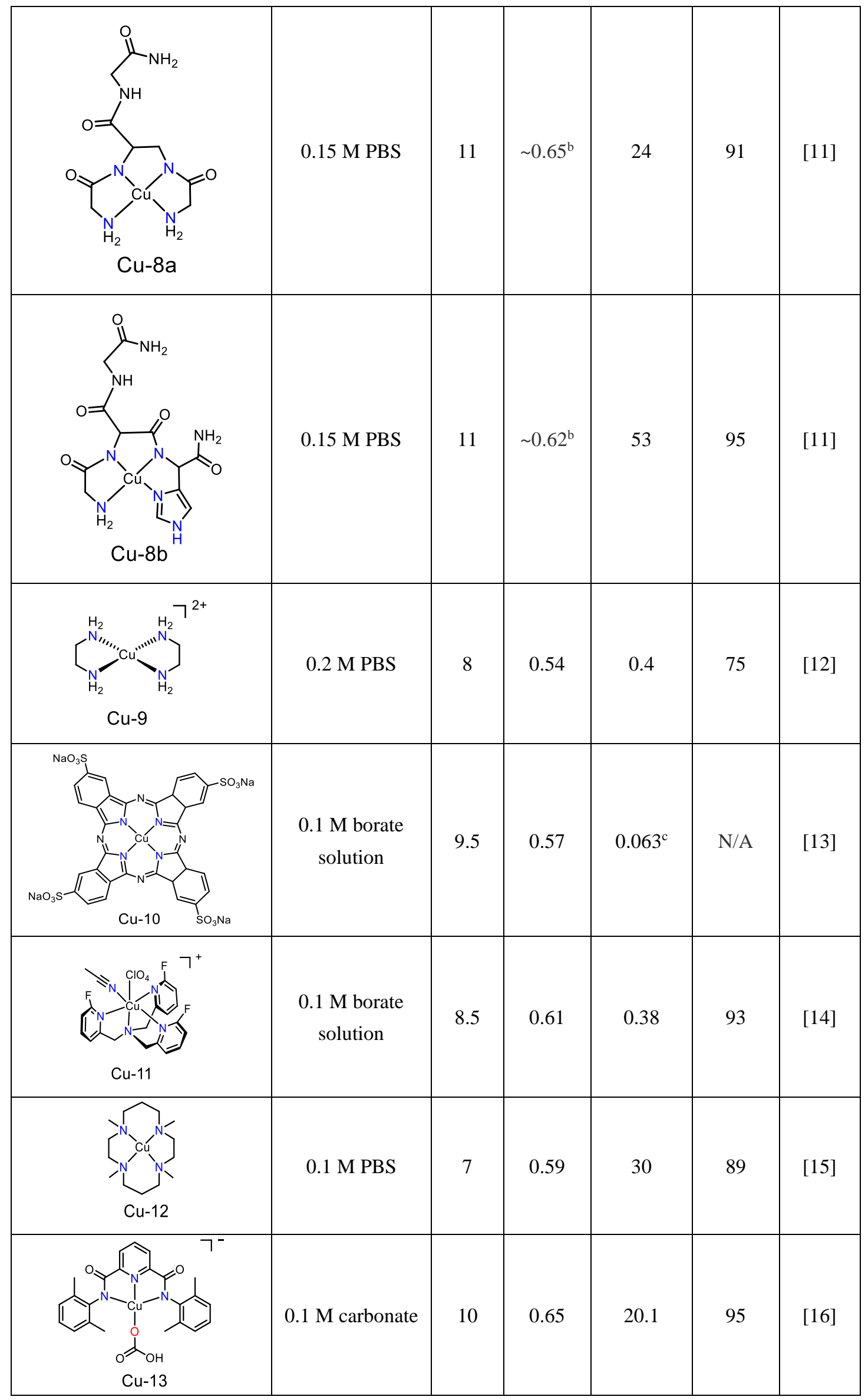




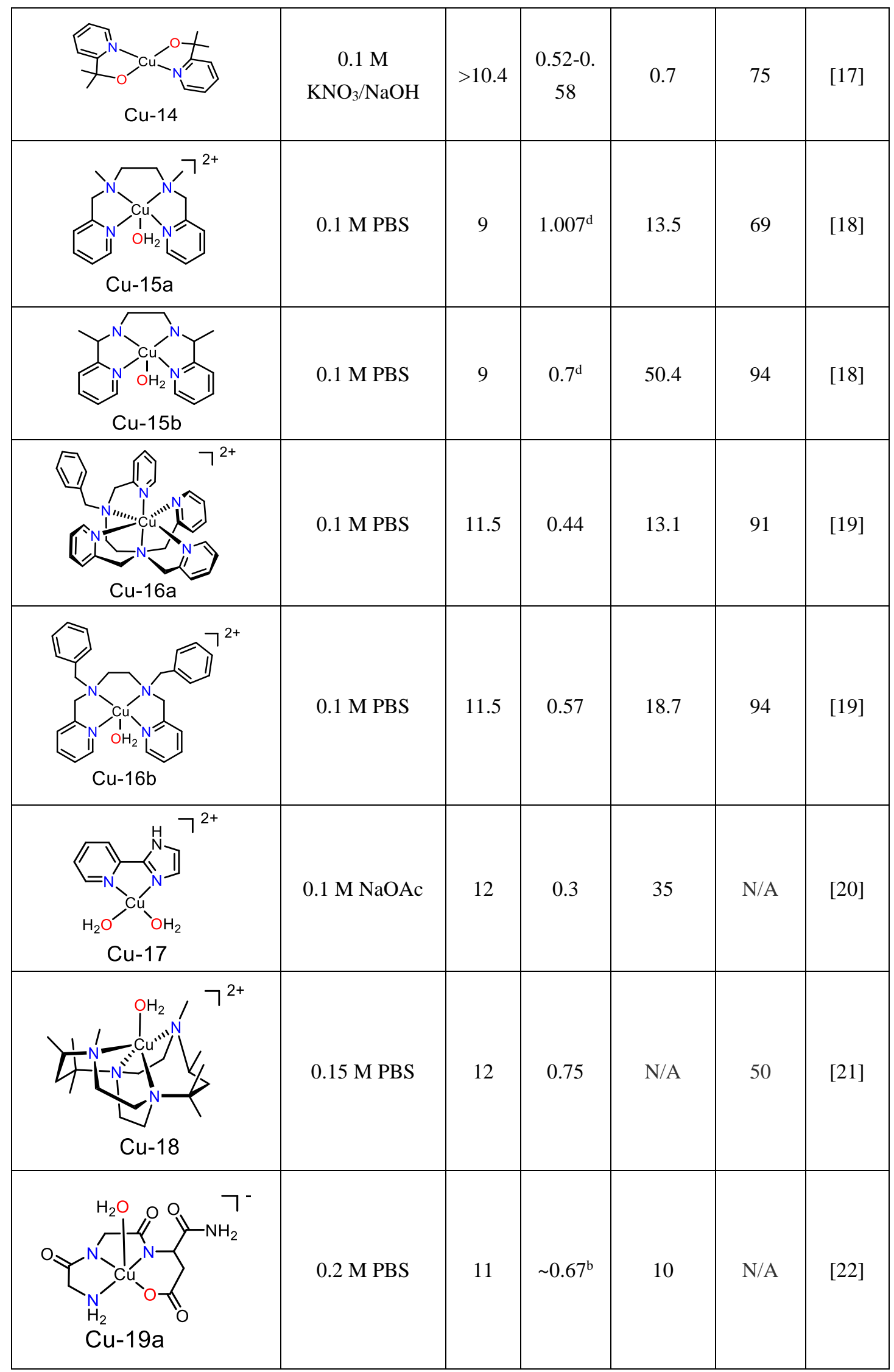




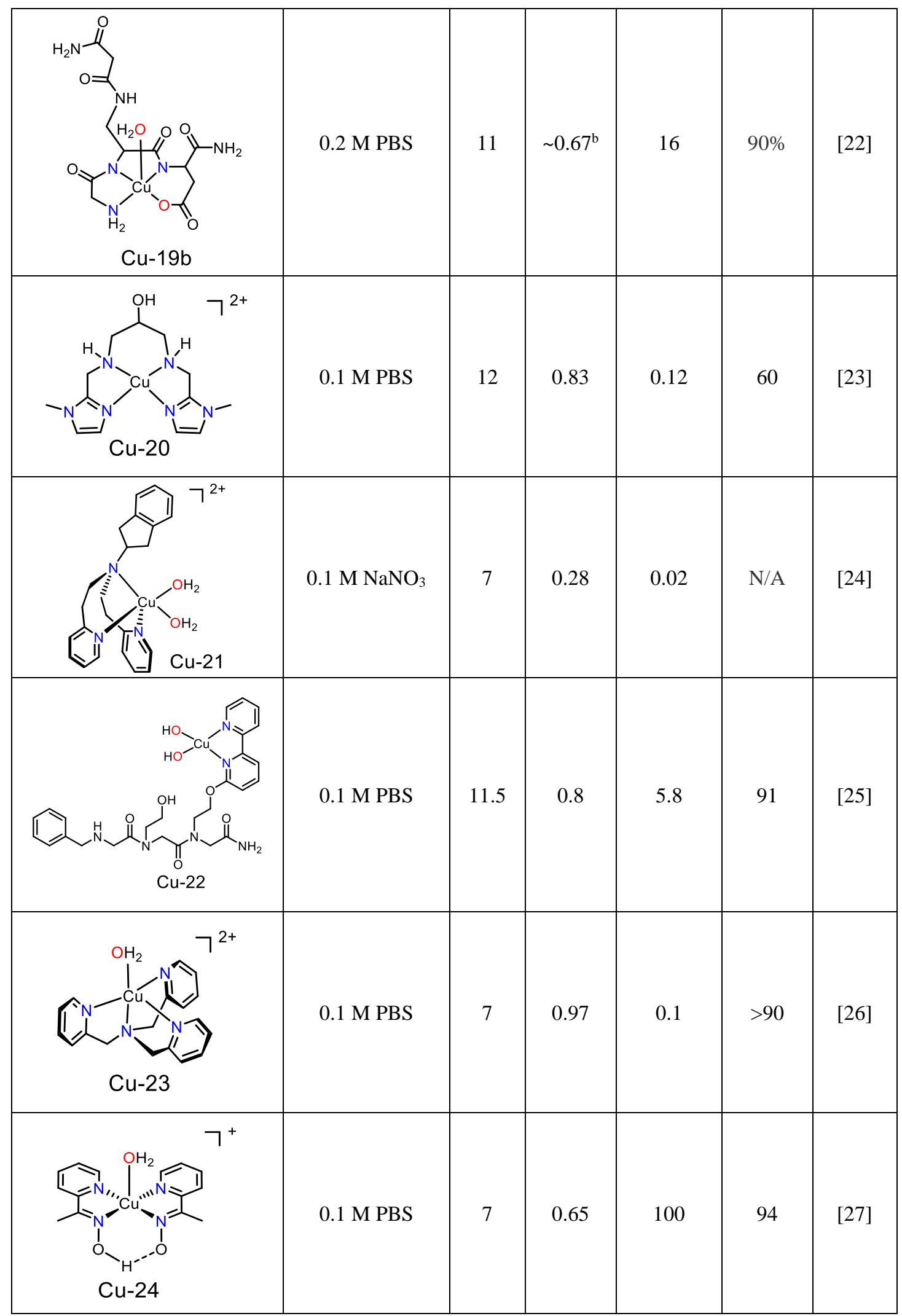




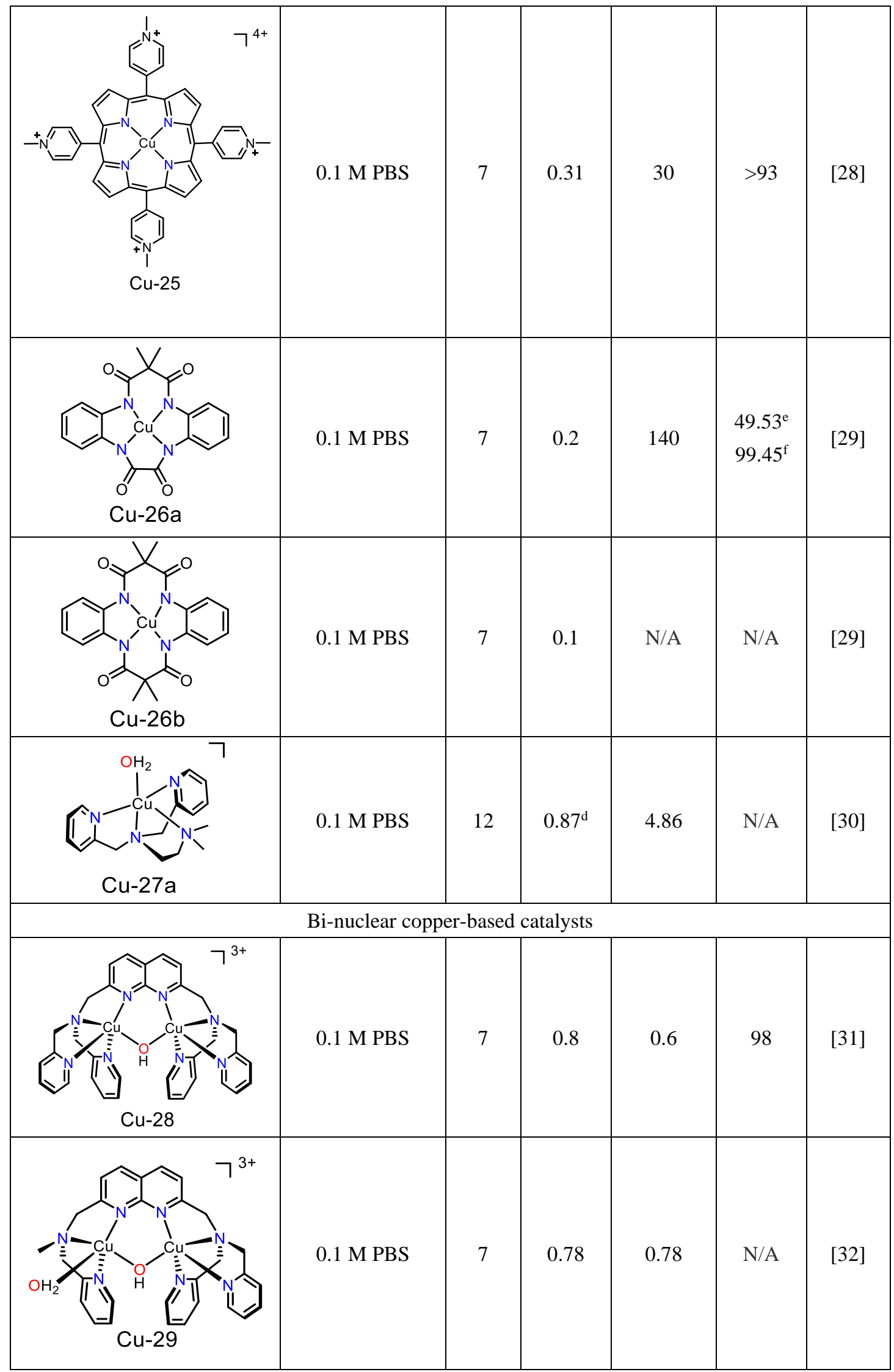




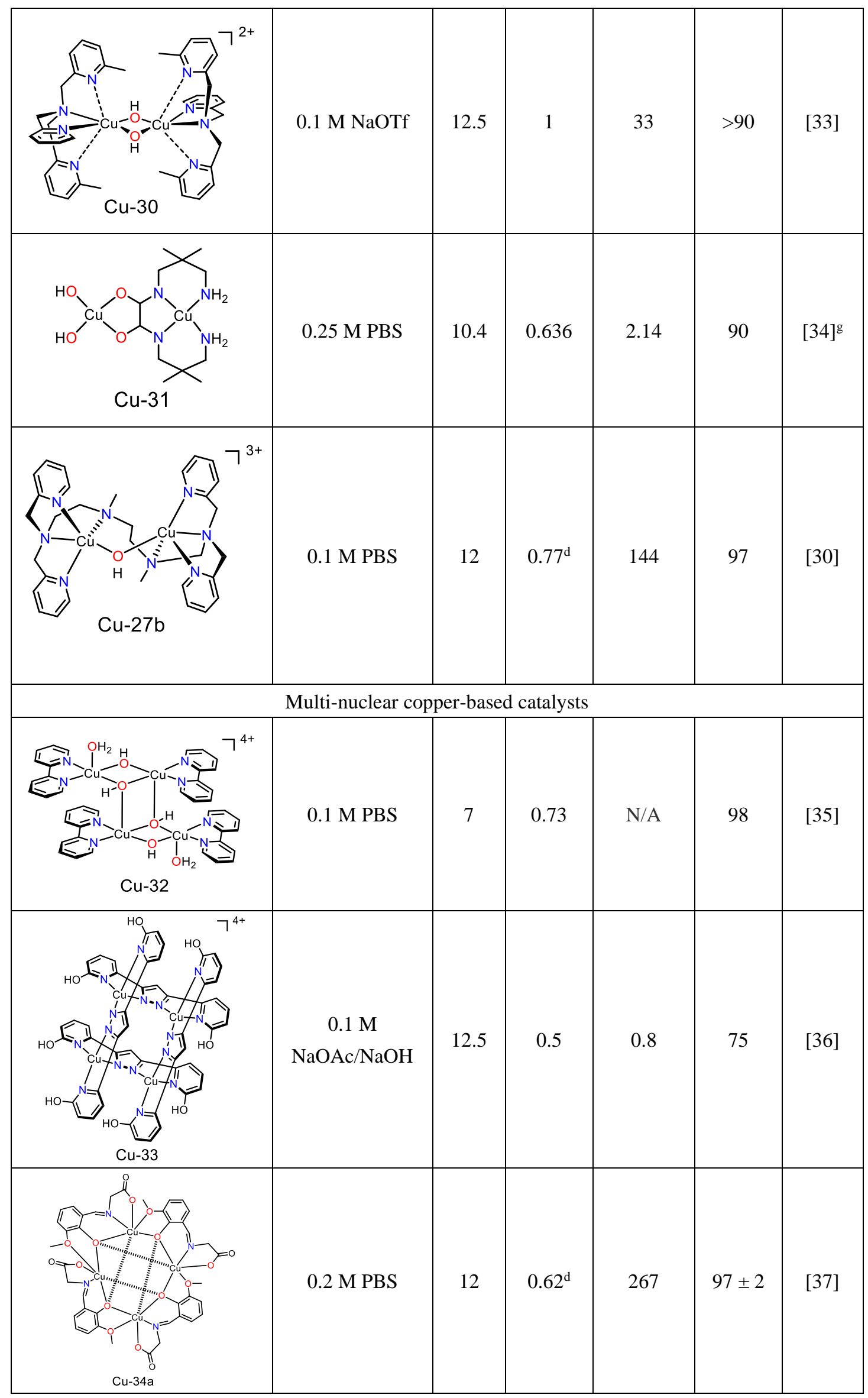




\begin{tabular}{|l|l|l|l|l|l|}
\hline & & & & & \\
\hline
\end{tabular}

${ }^{\text {aPotential }} v s$ NHE.

${ }^{\mathrm{b}}$ Calculated potential from the onset potential.

${ }^{\mathrm{c}}$ TOF calculation from light-driven catalysis.

${ }^{\mathrm{d} C}$ Calculated potential at current density at $1 \mathrm{~mA} \mathrm{~cm}^{-2}$.

${ }^{\mathrm{e}}$ Glassy carbon (GC) plate electrode as the working electrode during controlled potential electrolysis.

${ }^{\mathrm{f}}$ Boron-doped diamond (BDD) electrode as the working electrode during controlled potential electrolysis.

${ }^{\text {g}}$ Two copper ions are separated. 


\section{Section 9: Computational details}

The density functional calculations were accomplished with the hybrid B3LYP-D3 ${ }^{39,40}$ functional as implemented in the Gaussian 16 program package ${ }^{41}$. For geometry optimizations, the $\mathrm{SDD}^{42}$ pseudopotential was used for $\mathrm{Cu}$, while 6-31G(d,p) for the $\mathrm{C}, \mathrm{N}, \mathrm{O}, \mathrm{H}$ elements. Mulliken spin densities were calculated at the same level of theory as the geometry optimization for all structures. The final and the solvation energies were calculated as single-point corrections on the optimized structures using the $\mathrm{SMD}^{43}$ continuum solvation model employing the B3LYP*-D3 (15\% exact exchange, dispersion taken from B3LYP) functional $^{44}$ and a larger basis set, where all elements, except $\mathrm{Cu}$, were described by $6-311+G(2 d f, 2 p)$. The harmonic frequencies were computed on all the optimized structures at the same level of theory, to characterize the nature of various stationary points as minima (zero imaginary frequency) or transition states (one imaginary frequency) and to obtain the Gibbs free energy corrections at $298.15 \mathrm{~K}$. Reaction pathways were subjected to intrinsic reaction coordinate (IRC) analysis, ${ }^{45}$ in order to trace its path and to confirm that the optimized TS structure connects reactant and product. A concentration correction of 1.9 $\mathrm{kcal} / \mathrm{mol}$ at room temperature [derived from the free energy change of $1 \mathrm{~mol}$ of an ideal gas from $1 \mathrm{~atm}(24.5 \mathrm{~L} / \mathrm{mol}$ at $298.15 \mathrm{~K})$ to $1 \mathrm{M}(1 \mathrm{~mol} / \mathrm{L} \text { in aqueous solution) }]^{46,47}$ was added for all species except water, for which the corresponding values is $4.3 \mathrm{kcal} / \mathrm{mol}$, because the standard states of water is $55.56 \mathrm{~mol} / \mathrm{L}$. The reported energies are report the B3LYP*-D3 energies including Gibbs free energy corrections and D3 dispersion from B3LYP.

The $\mathrm{pKa}$ values were calculated in order to determine the protonation state of all species at the working $\mathrm{pH}=8.4$, and the experimental solvation energy of $-264.0 \mathrm{kcal} / \mathrm{mol}^{48}$ of a proton was used. The Gibbs free energy correction of $-6.3 \mathrm{kcal} / \mathrm{mol}$ derived from the translational entropy of a proton in the gas phase was added. The experimental solvation free energies of water $(-6.3 \mathrm{kcal} / \mathrm{mol})^{48}$ in aqueous solution were used. For the calculations of the redox potentials, the experimental absolute redox potential of $4.281 \mathrm{~V}^{49}$ for the standard hydrogen electrode (SHE) in water was used as a reference, which corresponds to an electron affinity of $98.72 \mathrm{kcal} / \mathrm{mol}$. This kind of approach has been used in the study of many other water oxidation catalysts, which has also been summarized in recent reviews ${ }^{45,50,51}$.

Barnett, S. M., Goldberg, K. I. \& Mayer, J. M. A soluble copper-bipyridine water-oxidation electrocatalyst. Nat. Chem. 4, 498-502 (2012).

5 Zhang, M. T., Chen, Z., Kang, P. \& Meyer, T. J. Electrocatalytic water oxidation with a copper(II) polypeptide complex. J. Am. Chem. Soc. 135, 2048-2051 (2013).

Coggins, M. K., Zhang, M.-T., Chen, Z., Song, N. \& Meyer, T. J. Single-site copper(II) water oxidation electrocatalysis: Rate enhancements with $\mathrm{HPO}_{4}{ }^{2-}$ as a proton acceptor at $\mathrm{pH}$ 8. Angew. Chem. Int. Ed. 53, 12226-12230 (2014).

Fu, L.-Z., Fang, T., Zhou, L.-L. \& Zhan, S.-Z. A mononuclear copper electrocatalyst for both water reduction and oxidation. $R S C A d v$. 4, 53674-53680 (2014).

Gerlach, D. L. et al. Studies of the pathways open to copper water oxidation catalysts containing proximal hydroxy groups during basic electrocatalysis. Inorg. Chem. 53, 12689-12698 (2014).

Zhang, T., Wang, C., Liu, S., Wang, J. L. \& Lin, W. A biomimetic copper water oxidation catalyst with low overpotential. J. Am. Chem. Soc. 136, 273-281 (2014). 

family of mononuclear Cu-based efficient catalysts. J. Am. Chem. Soc. 137, 6758-6761 (2015). Pap, J. S. et al. Electrocatalytic water oxidation by $\mathrm{Cu}(\mathrm{II})$ complexes with branched peptides. Chem. Commun. 51, 6322-6324 (2015).

$\mathrm{Lu}, \mathrm{C}$. et al. $\mathrm{Cu}(\mathrm{II})$ aliphatic diamine complexes for both heterogeneous and homogeneous water oxidation catalysis in basic and neutral solutions. ACS Catal. 6, 77-83 (2015).

Terao, R., Nakazono, T., Parent, A. R. \& Sakai, K. Photochemical water oxidation catalyzed by a water-soluble copper phthalocyanine complex. ChemPlusChem 81, 1064-1067 (2016).

Xiang, R. J. et al. A water-soluble copper-polypyridine complex as a homogeneous catalyst for both photo-induced and electrocatalytic $\mathrm{O}_{2}$ evolution. Chem. Eur. J. 22, 1602-1607 (2016).

$\mathrm{Yu}$, F. et al. Electrocatalytic water oxidation by a macrocyclic $\mathrm{Cu}(\mathrm{II})$ complex in neutral phosphate buffer. Chem. Commun. 52, 10377-10380 (2016).

Chen, F. et al. Electrocatalytic water oxidation by a water-soluble copper(II) complex with a copper-bound carbonate group acting as a potential proton shuttle. Inorg. Chem. 56, 13368-13375 (2017).

Fisher, K. J., Materna, K. L., Mercado, B. Q., Crabtree, R. H. \& Brudvig, G. W. Electrocatalytic water oxidation by a copper(II) complex of an oxidation-resistant ligand. ACS Catal. 7, 3384-3387 (2017). Shen, J. et al. Improvement of electrochemical water oxidation by fine-tuning the structure of tetradentate N4 ligands of molecular copper catalysts. ChemSusChem 10, 4581-4588 (2017).

Shen, J., Wang, M., Zhang, P., Jiang, J. \& Sun, L. Electrocatalytic water oxidation by copper(II) complexes containing a tetra- or pentadentate amine-pyridine ligand. Chem. Commun. 53, 4374-4377 (2017). overpotentials using the ionisable imidazole of copper(2-(2'-pyridyl)imidazole). Chem. Commun. 53 651-654 (2017).

Wang, J., Huang, H. \& Lu, T. Homogeneous electrocatalytic water oxidation by a rigid macrocyclic copper(II) complex. Chin. J. Chem. 35, 586-590 (2017).

Szyrwiel, Ł. et al. Armed by Asp? C-terminal carboxylate in a Dap-branched peptide and consequences in the binding of $\mathrm{Cu}^{\mathrm{II}}$ and electrocatalytic water oxidation. $R S C A d v .7,24657-24666$ (2017).

Nestke, S., Ronge, E. \& Siewert, I. Electrochemical water oxidation using a copper complex. Dalton Trans. 47, 10737-10741 (2018).

Kafentzi, M. C. et al. Electrochemical water oxidation and stereoselective oxygen atom transfer mediated by a copper complex. Chem. Eur. J. 24, 5213-5224 (2018).

Ghosh, T., Ghosh, P. \& Maayan, G. A copper-peptoid as a highly stable, efficient, and reusable homogeneous water oxidation electrocatalyst. ACS Catal. 8, 10631-10640 (2018).

$\mathrm{Su}, \mathrm{X}$. J. et al. Bimetallic cooperative effect on $\mathrm{O}-\mathrm{O}$ bond formation: copper polypyridyl complexes as water oxidation catalyst. Dalton Trans. 47, 8670-8675 (2018).

Kuilya, H., Alam, N., Sarma, D., Choudhury, D. \& Kalita, A. Ligand assisted electrocatalytic water oxidation by a copper(II) complex in neutral phosphate buffer. Chem. Commun. 55, 5483-5486 (2019). Liu, Y. et al. Low overpotential water oxidation at neutral pH catalyzed by a copper(II) porphyrin. Chem. Sci. 10, 2613-2622 (2019). Garrido-Barros, P. et al. Redox metal-ligand cooperativity enables robust and efficient water oxidation catalysis at neutral pH with macrocyclic copper complexes. J. Am. Chem. Soc. 142, 17434-17446 (2020). Zhang, X. et al. A dinuclear copper complex featuring a flexible linker as water oxidation catalyst with an activity far superior to its mononuclear counterpart. Inorg. Chem. 59, 5424-5432 (2020). 
$\mathrm{Su}, \mathrm{X}$. J. et al. Electrocatalytic water oxidation by a dinuclear copper complex in a neutral aqueous solution. Angew. Chem. Int. Ed. 54, 4909-4914 (2015).

Hu, Q. Q., Su, X. J. \& Zhang, M. T. Electrocatalytic water oxidation by an unsymmetrical di-copper complex. Inorg. Chem. 57, 10481-10484 (2018).

Koepke, S. J., Light, K. M., VanNatta, P. E., Wiley, K. M. \& Kieber-Emmons, M. T. Electrocatalytic water oxidation by a homogeneous copper catalyst disfavors single-site mechanisms. J. Am. Chem. Soc. 139, 8586-8600 (2017).

Zhou, L. L. et al. A dinuclear copper(II) electrocatalyst both water reduction and oxidation. J. Power Sources 273, 298-304 (2015).

Li, T. T. \& Zheng, Y. Q. Electrocatalytic water oxidation using a chair-like tetranuclear copper(II) complex in a neutral aqueous solution. Dalton Trans. 45, 12685-12690 (2016).

Praneeth, V. K. K., Kondo, M., Woi, P. M., Okamura, M. \& Masaoka, S. Electrocatalytic water oxidation by a tetranuclear copper complex. Chempluschem 81, 1123-1128 (2016).

Jiang, X. et al. A bio-inspired $\mathrm{Cu}_{4} \mathrm{O}_{4}$ cubane: effective molecular catalysts for electrocatalytic water oxidation in aqueous solution. Angew. Chem. Int. Ed. 57, 7850-7854 (2018). property and electrocatalytic reactivity for water oxidation. Chem. Asian J. 14, 2685-2693 (2019).

Becke, A. D. Density-functional thermochemistry. III. The role of exact exchange. J. Chem. Phys. 98, 5648-5652 (1993). density functional dispersion correction (DFT-D) for the 94 elements H-Pu. J. Chem. Phys. 132, 154104-154118 (2010).

Gaussian 16, Revision A.03, Frisch, M. J.; Trucks, G. W.; Schlegel, H. B.; Scuseria, G. E.; Robb, M. A.; Cheeseman, J. R.; Scalmani, G.; Barone, V.; Petersson, G. A.; Nakatsuji, H.; Li, X.; Caricato, M.; Marenich, A. V.; Bloino, J.; Janesko, B. G.; Gomperts, R.; Mennucci, B.; Hratchian, H. P.; Ortiz, J. V.; Izmaylov, A. F.; Sonnenberg, J. L.; Williams-Young, D.; Ding, F.; Lipparini, F.; Egidi, F.; Goings, J.; Peng, B.; Petrone, A.; Henderson, T.; Ranasinghe, D.; Zakrzewski, V. G.; Gao, J.; Rega, N.; Zheng, G.; Liang, W.; Hada, M.; Ehara, M.; Toyota, K.; Fukuda, R.; Hasegawa, J.; Ishida, M.; Nakajima, T.; Honda, Y.; Kitao, O.; Nakai, H.; Vreven, T.; Throssell, K.; Montgomery, J. A., Jr.; Peralta, J. E.; Ogliaro, F.; Bearpark, M. J.; Heyd, J. J.; Brothers, E. N.; Kudin, K. N.; Staroverov, V. N.; Keith, T. A.; Kobayashi, R.; Normand, J.; Raghavachari, K.; Rendell, A. P.; Burant, J. C.; Iyengar, S. S.; Tomasi, J.; Cossi, M.; Millam, J. M.; Klene, M.; Adamo, C.; Cammi, R.; Ochterski, J. W.; Martin, R. L.; Morokuma, K.; Farkas, O.; Foresman, J. B.; Fox, D. J. Gaussian, Inc., Wallingford CT, 2016.

Andrae, D., HaiuBermann, U., Dolg, M., Stoll, H. \& Preu, H. Energy-adjusted ab initio pseudopotentials for the second and third row transition elements. Theor. Chim. Acta 77, 123-141 (1990).

Marenich, A. V., Cramer, C. J. \& Truhlar, D. G. Universal solvation model based on solute electron density and on a continuum model of the solvent defined by the bulk dielectric constant and atomic surface tensions. J. Phys. Chem. B 113, 6378-6396 (2009).

Reiher, M., Salomon, O. \& Artur Hess, B. Reparameterization of hybrid functionals based on energy differences of states of different multiplicity. Theoretical Chemistry Accounts 107, 48-55 (2001).

Gonzalez, C. \& Schlegel, H. B. An improved algorithm for reaction path following. J. Chem. Phys. 90, 2154-2161 (1989).

Marenich, A. V., Ho, J., Coote, M. L., Cramer, C. J. \& Truhlar, D. G. Computational electrochemistry: prediction of liquid-phase reduction potentials. Phys. Chem. Chem. Phys. 16, 15068-15106 (2014). 
47 Morello, G. R. \& Hopmann, K. H. A dihydride mechanism can explain the intriguing substrate selectivity of iron-PNP-mediated hydrogenation. ACS Catal. 7, 5847-5855 (2017).

48 Camaioni, D. M. \& Schwerdtfeger, C. A. Comment on "Accurate experimental values for the free energies of hydration of $\mathrm{H}^{+}, \mathrm{OH}^{-}$, and $\mathrm{H}_{3} \mathrm{O}^{+\prime}$. J. Phys. Chem. A 109, 10795-10797 (2005).

49 Isse, A. A. \& Gennaro, A. Absolute potential of the standard hydrogen electrode and the problem of interconversion of potentials in different solvents. J. Phys. Chem. B 114, 7894-7899 (2010).

50 Liao, R. Z. \& Siegbahn, P. E. M. Quantum chemical modeling of homogeneous water oxidation catalysis. ChemSusChem 10, 4236-4263 (2017).

51 Schilling, M. \& Luber, S. Computational modeling of cobalt-based water oxidation: current status and future challenges. Front. Chem. 6, 100 (2018). 


\section{Structures of all stationary points}

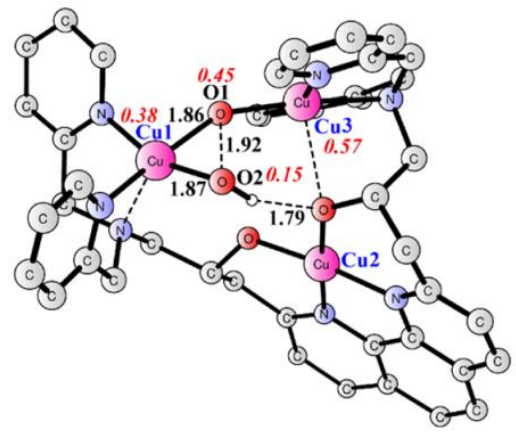

TS1'

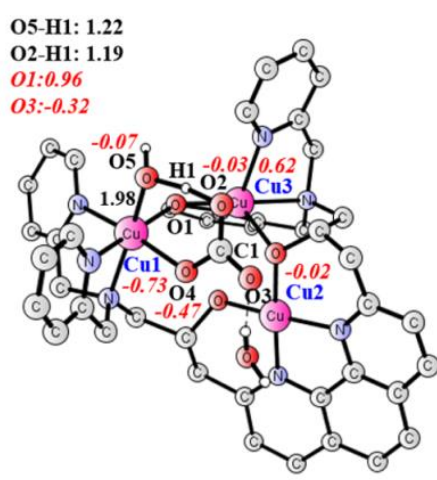

TS0"

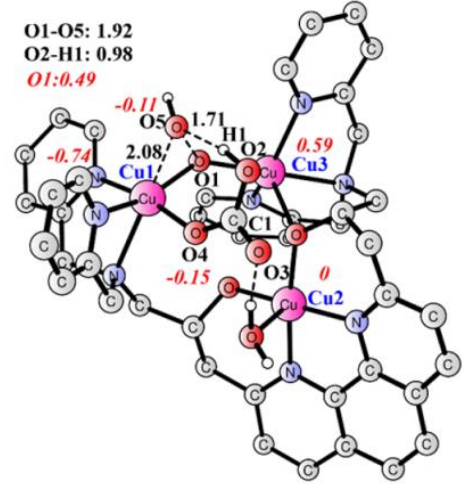

TS1"

Figure S45 | Optimized structures of transition states. Distances are given in Angstrom, and spin densities on selected atoms are shown in red italics.

It should be mentioned that further one-electron oxidation of $\mathbf{4}^{\prime}$ to generate $\mathbf{5}^{\prime}\left(\mathrm{Cu}^{\mathrm{III}}{ }_{2} \mathrm{Cu}^{\mathrm{IV}}\right)$ is associated with a potential of $1.773 \mathrm{~V}$. In 5', the bridging oxyl radical and the CO3 ${ }^{--}$radical may have either the same (5'ferro) or the opposite (5'anti) spin densities. The opposite spin densities would favor the following $\mathrm{O}-\mathrm{O}$ bond formation, but its energy is $3.8 \mathrm{kcal} / \mathrm{mol}$ higher. Taking this energy difference into account, the oxidation potential for the $\mathbf{5}$ ' anti $/ \mathbf{4}$ couple becomes $1.936 \mathrm{~V}$. O-O bond formation from $\mathbf{5}$ ' anti has also been taken into account, and the calculations showed that a tiny conformation change leads to the $\mathrm{O}-\mathrm{O}$ bond formation with a negligible barrier. These results indicate that at an applied potential of $2.14 \mathrm{~V}$ (catalytic peak current of $16.6 \mathrm{~mA} \mathrm{~cm}^{-2}$ ), further access into the $\mathrm{Cu}^{\mathrm{III}}{ }_{2} \mathrm{Cu}^{\mathrm{IV}}$ is possible. However, in our CPE experiment with an applied potential of $1.64 \mathrm{~V}$, the access to $\mathbf{5}$ ' becomes less likely. 


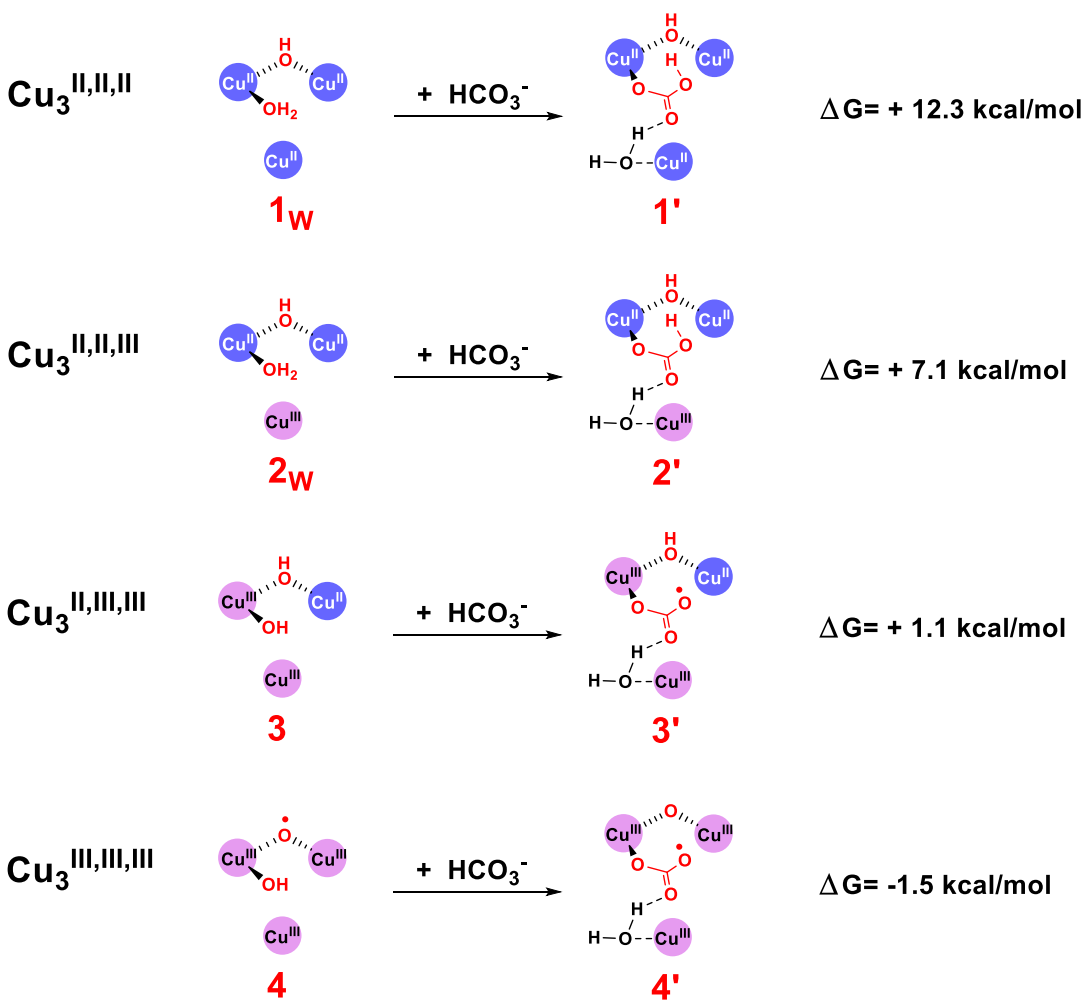

Scheme S1 | Schematic representation of the binding of $\mathrm{HCO}_{3}^{-}$to the catalyst at different oxidation states. 


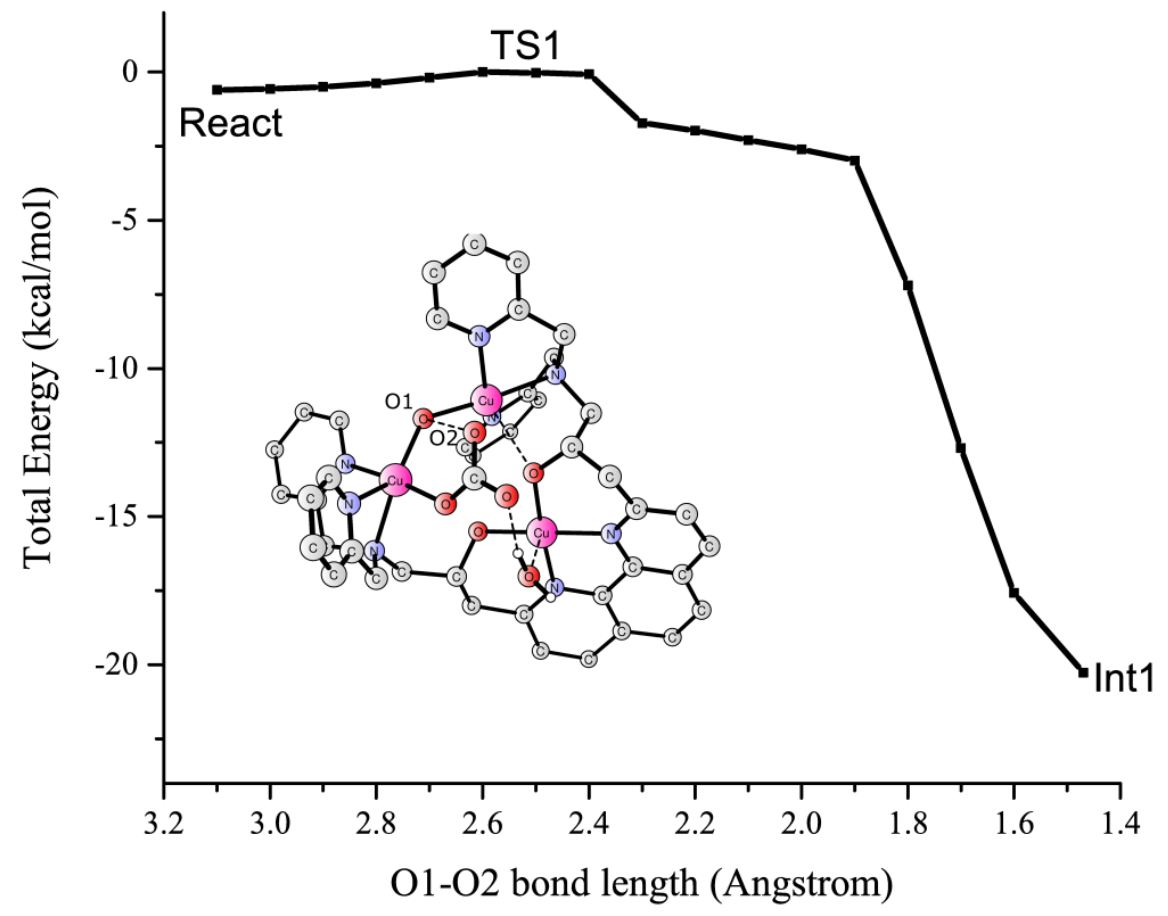

Figure S46 | Potential energy scan (in $\mathrm{kcal} / \mathrm{mol}$ ) along the O1-O2 distance for TS1. TS1 has only one imaginary frequency of $27.8 i \mathrm{~cm}^{-1}$.
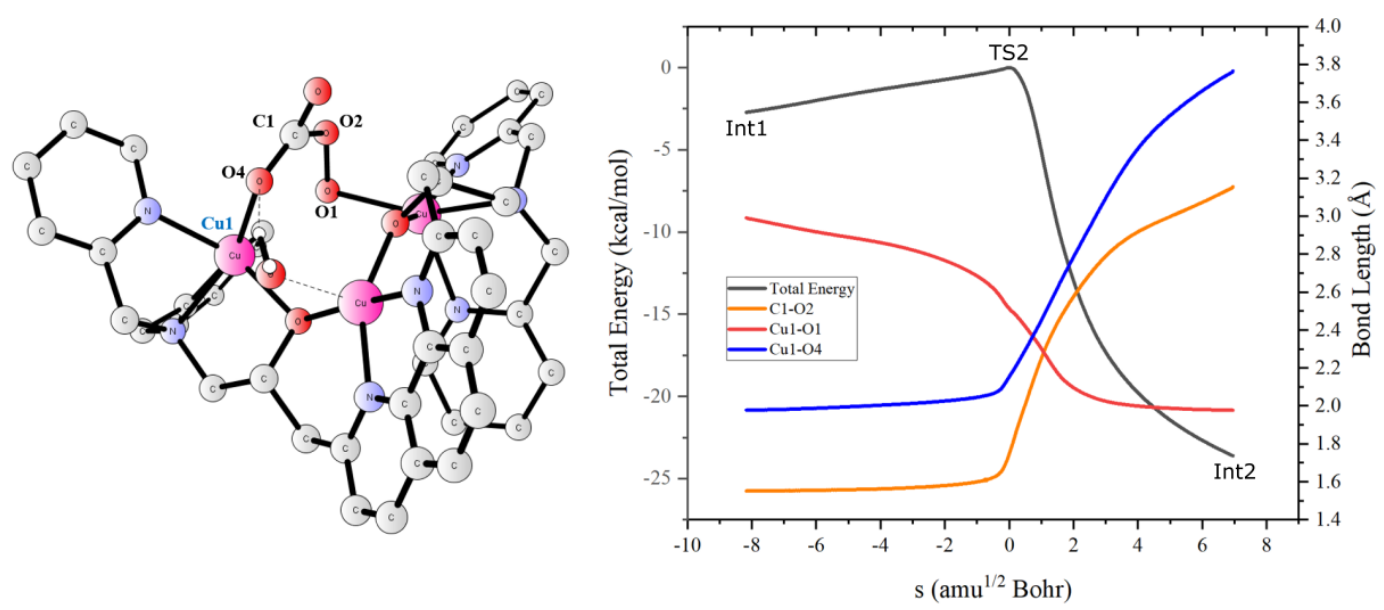

TS2

Figure S47 | Intrinsic reaction coordinate profile for TS2. Relative energies are given in $\mathrm{kcal} / \mathrm{mol}$, while distances are given in Angstrom. TS2 has only one imaginary frequency of $139.4 i \mathrm{~cm}^{-1}$. 


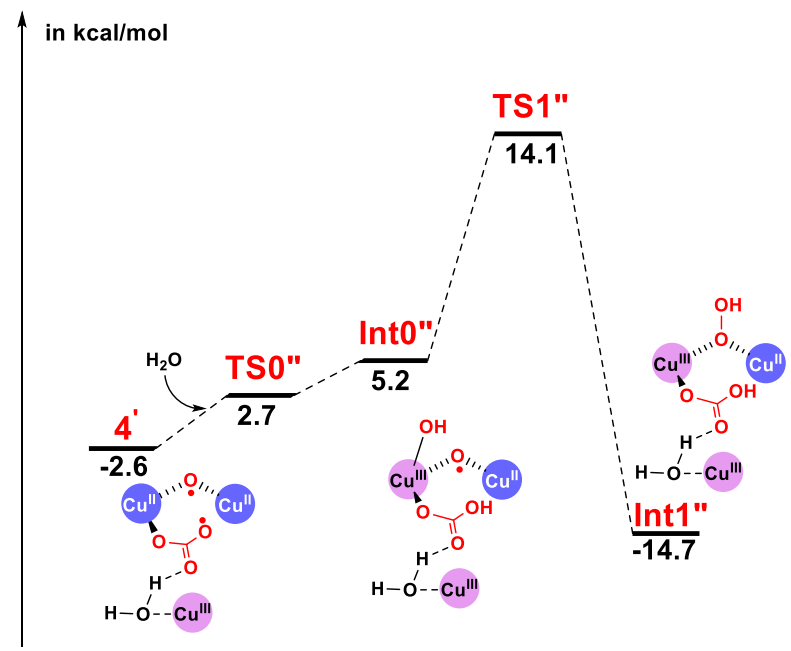

Figure S48 | Potential energy profile (in $\mathrm{kcal} / \mathrm{mol}$ ) for O-O bond formation from 4' via a copper-assisted water attack mechanism.
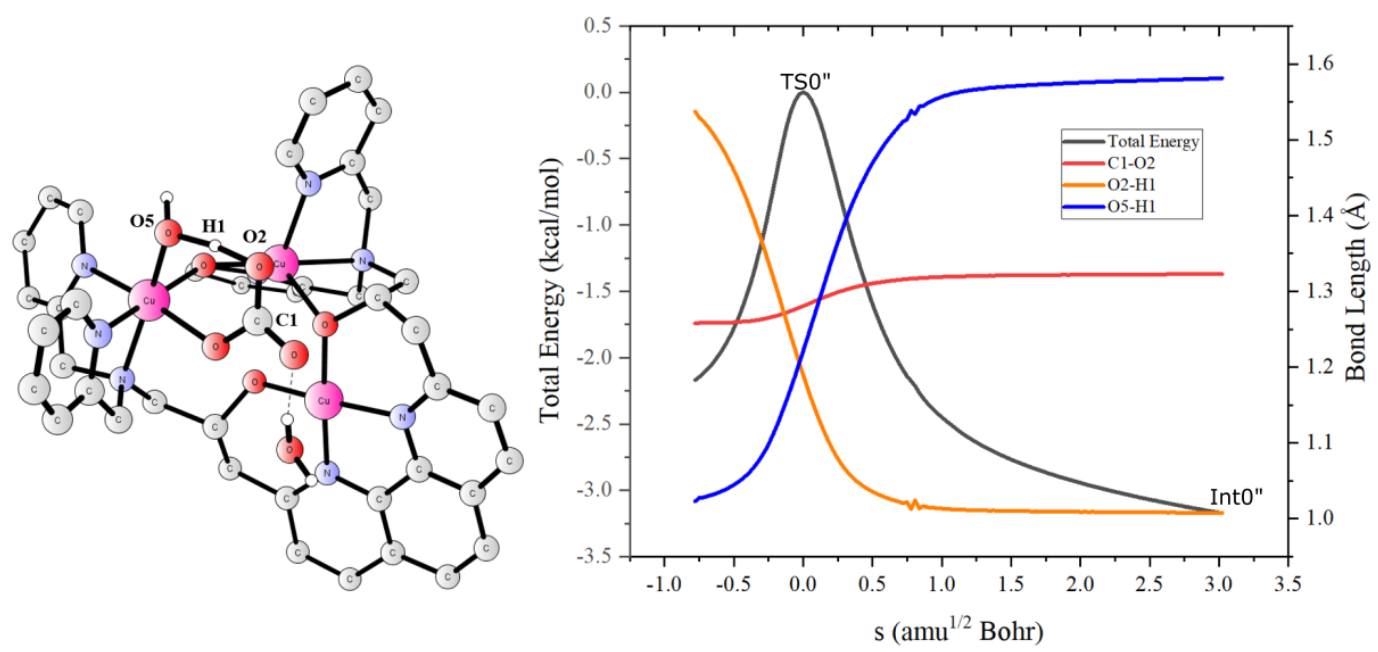

TS0"

Figure S49 | Intrinsic reaction coordinate profile for TS0". Relative energies are given in $\mathrm{kcal} / \mathrm{mol}$, while distances are given in Angstrom. TS0" has only one imaginary frequency of $960.3 i \mathrm{~cm}^{-1}$. 

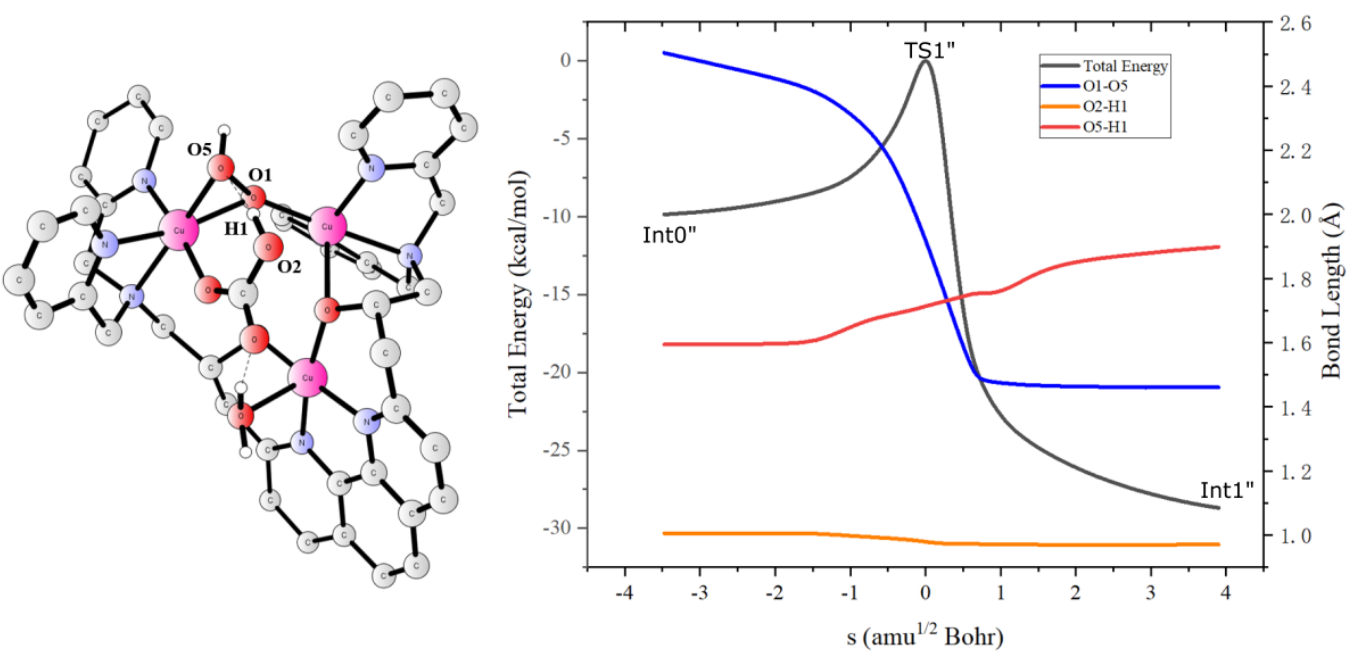

TS1"

Figure S50 | Intrinsic reaction coordinate profile for TS1". Relative energies are given in $\mathrm{kcal} / \mathrm{mol}$, while distances are given in Angstrom. TS1" has only one imaginary frequency of $644.6 i \mathrm{~cm}^{-1}$.

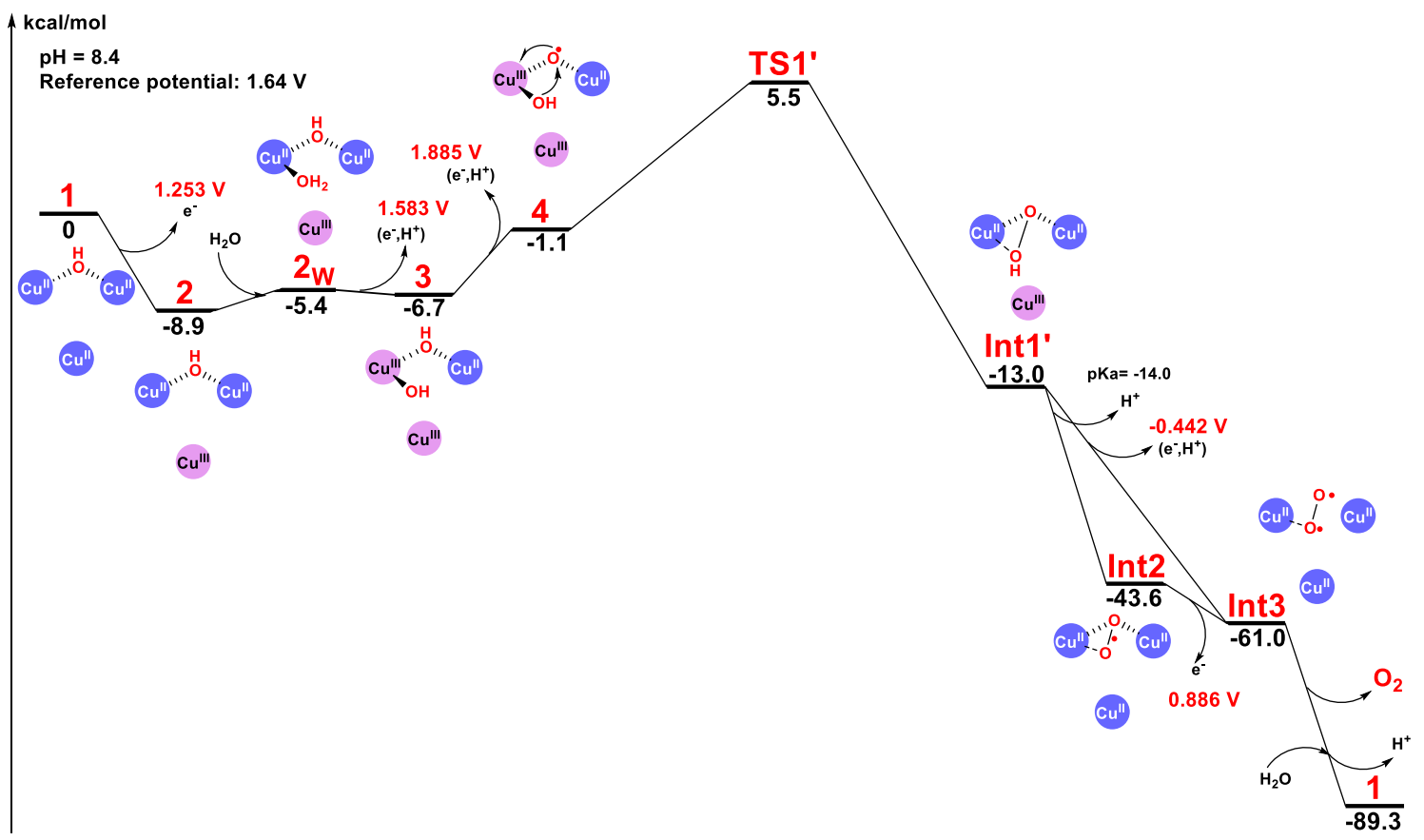

Figure S51 | Potential energy profile (in $\mathrm{kcal} / \mathrm{mol}$ ) for water oxidation catalyzed by $\mathbf{1}$ without the assistance of carbonate. 

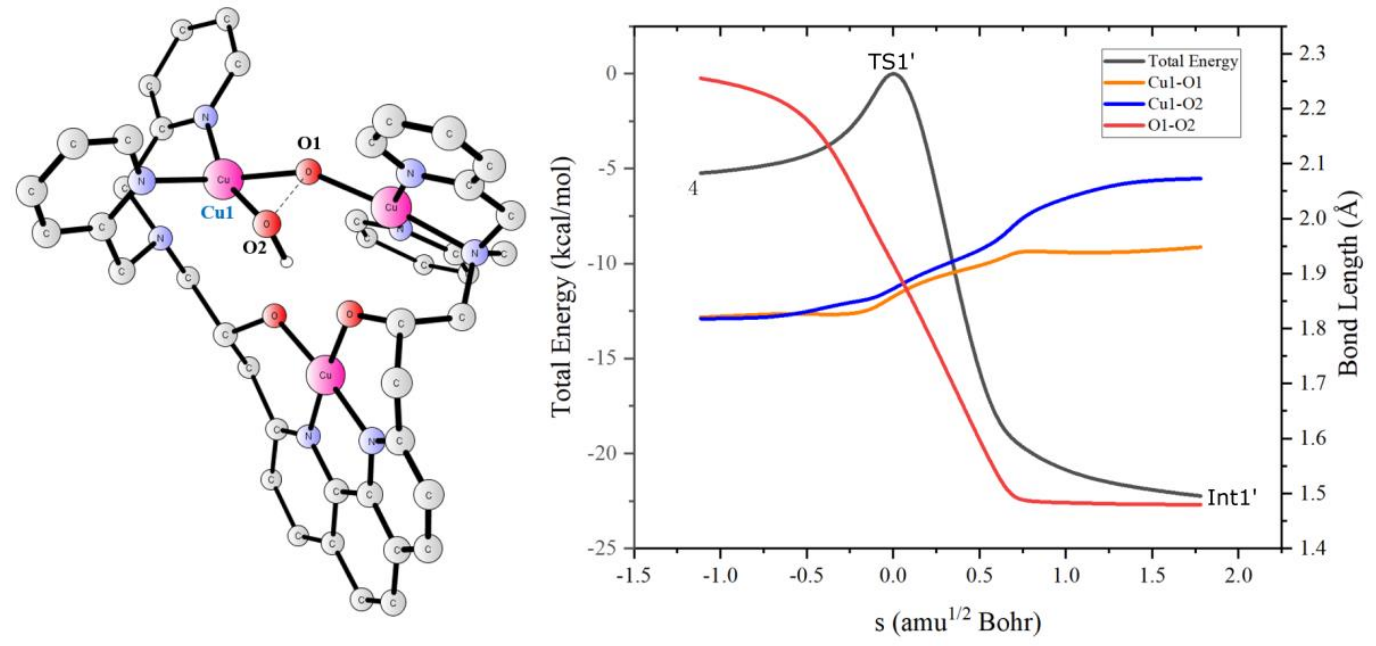

TS1'

Figure S52 | Intrinsic reaction coordinate profile for TS1'. Relative energies are given in $\mathrm{kcal} / \mathrm{mol}$, while distances are given in Angstrom. TS1' has only one imaginary frequency of $720.4 i \mathrm{~cm}^{-1}$. 


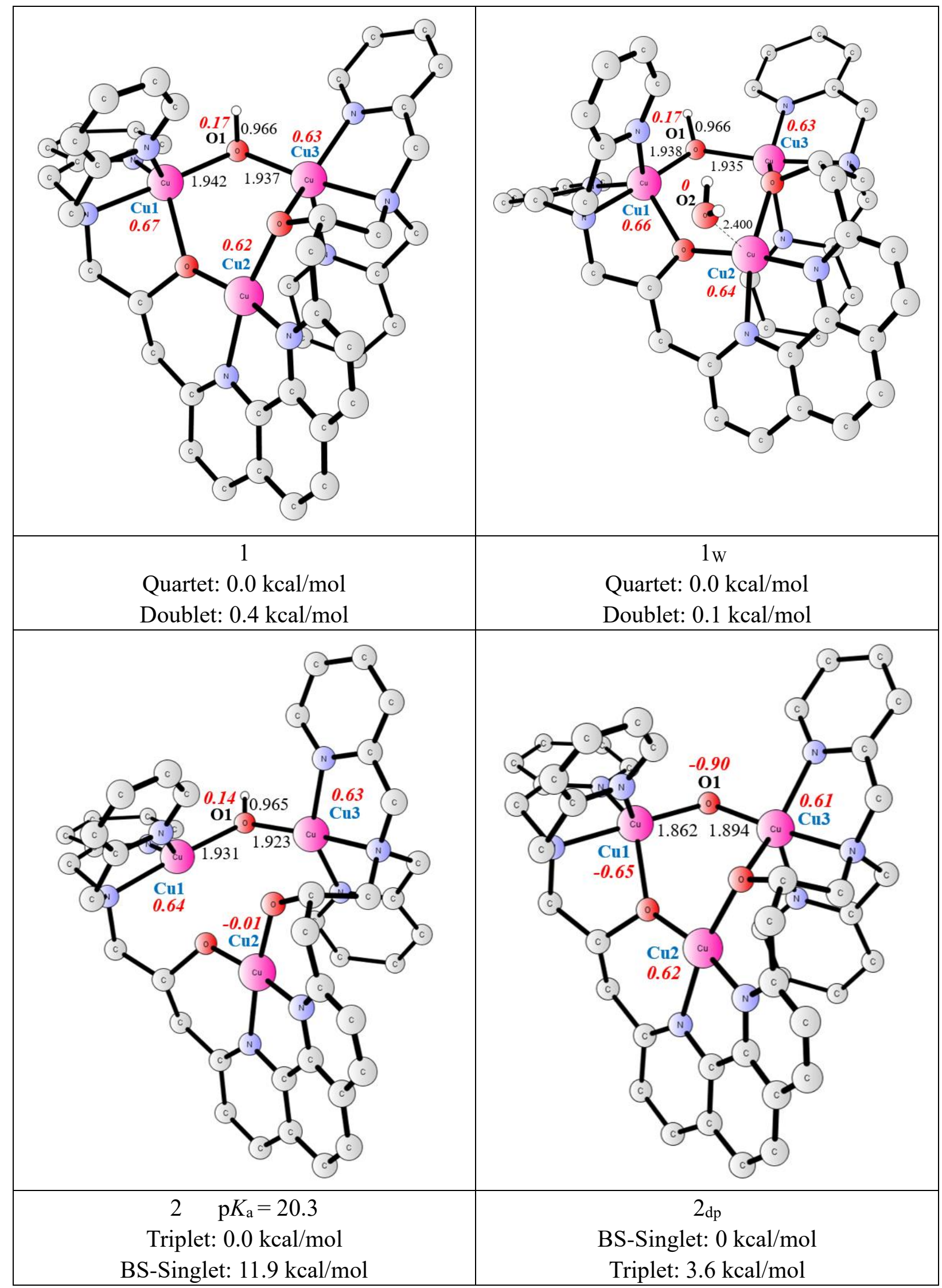




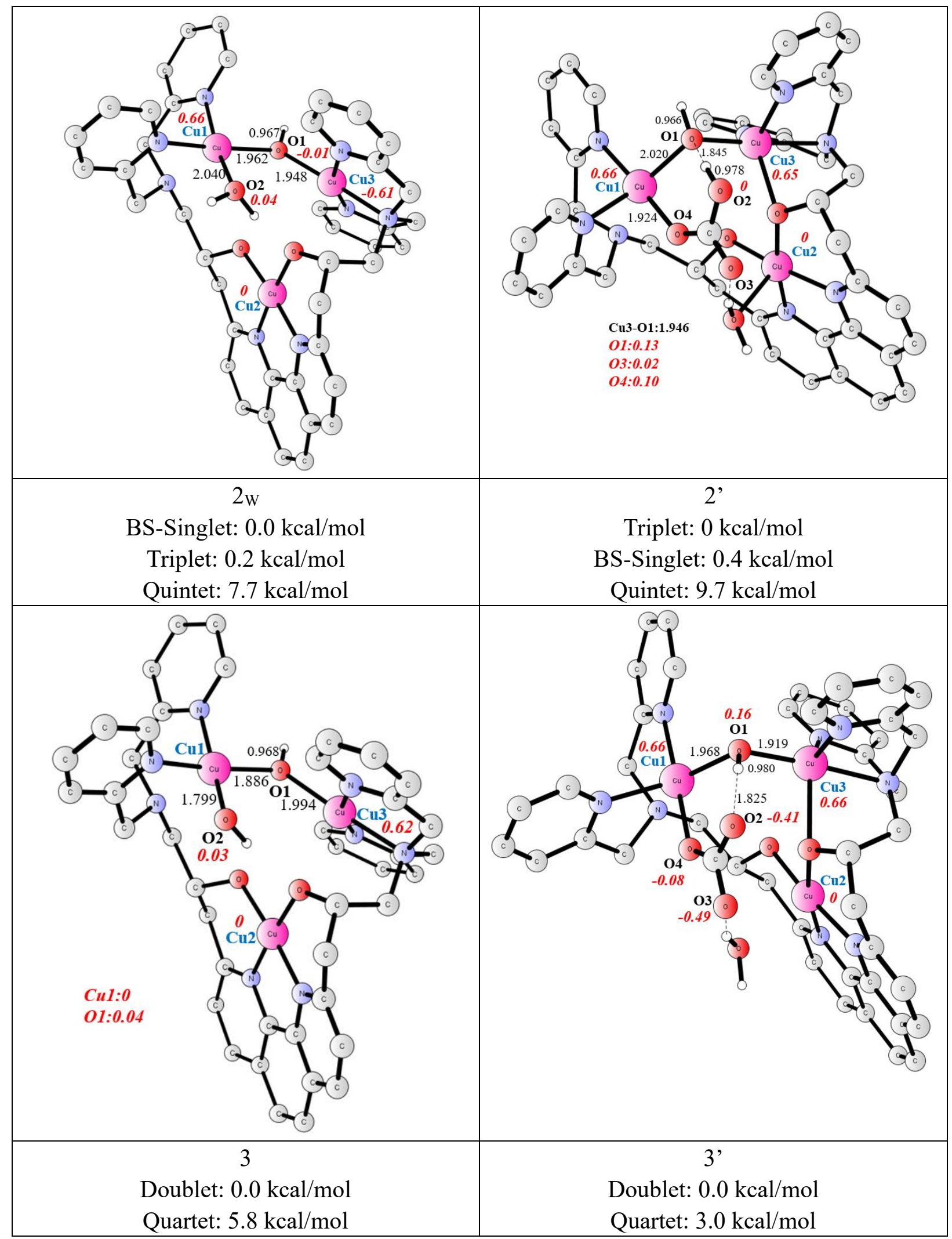




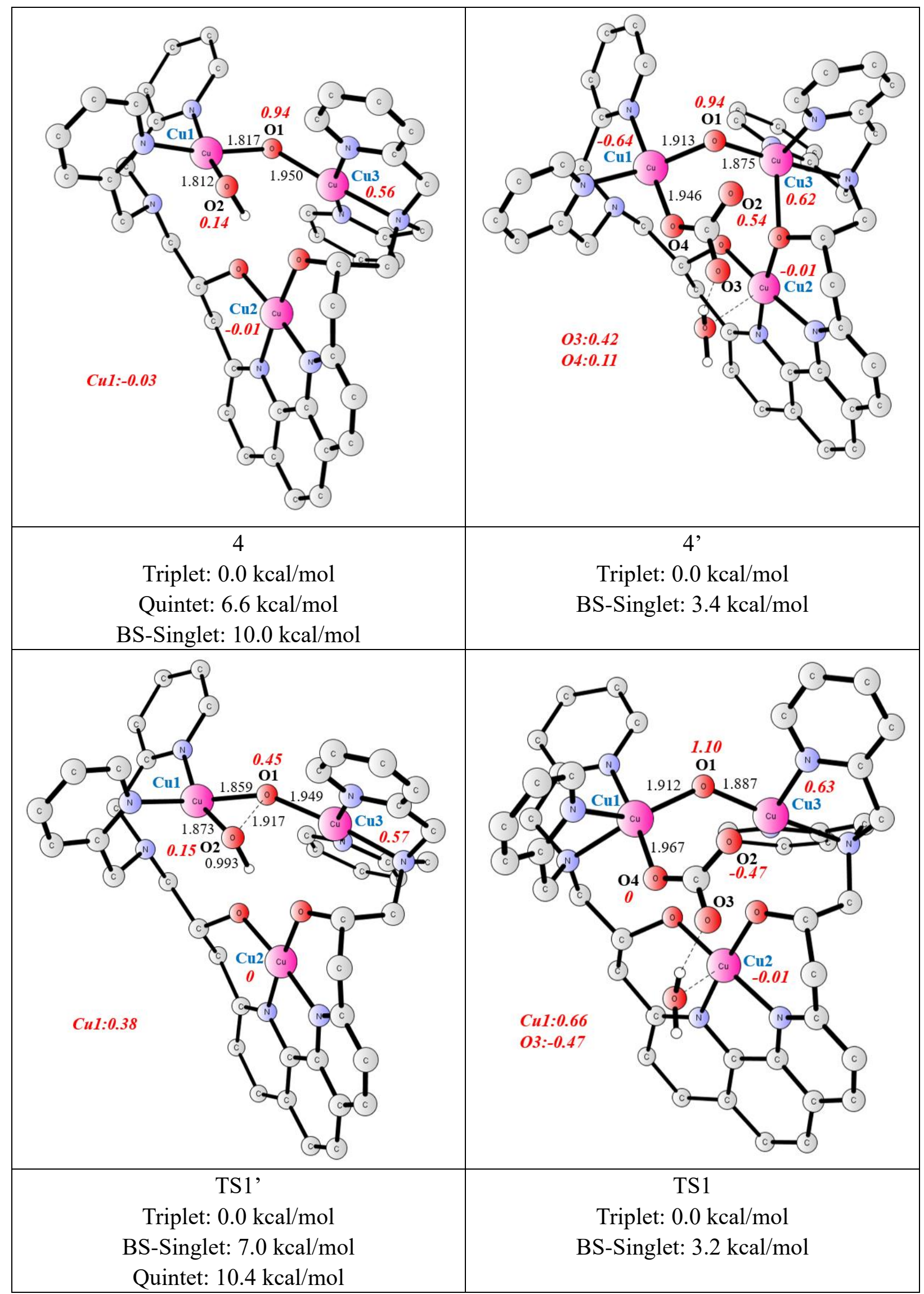




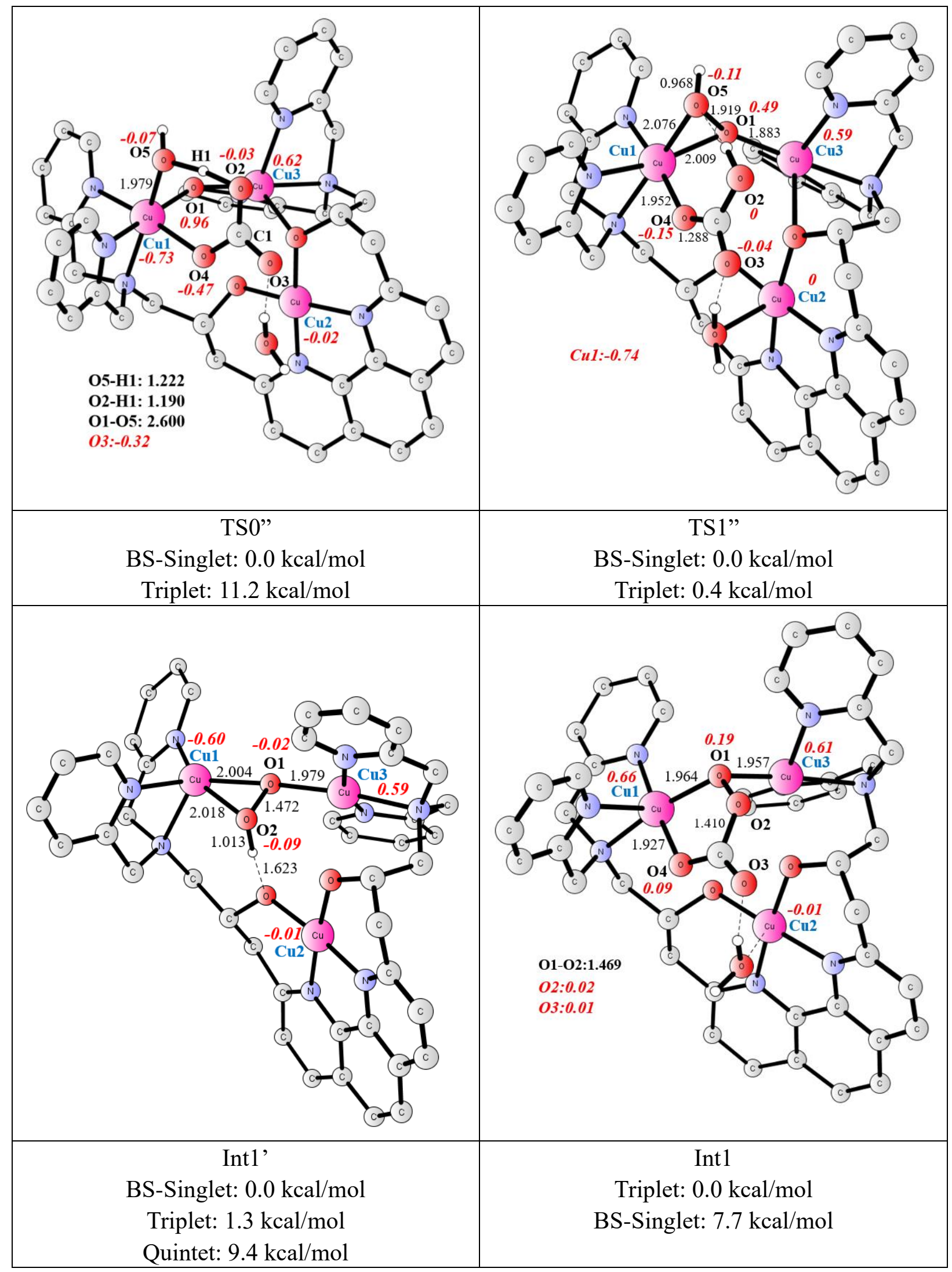




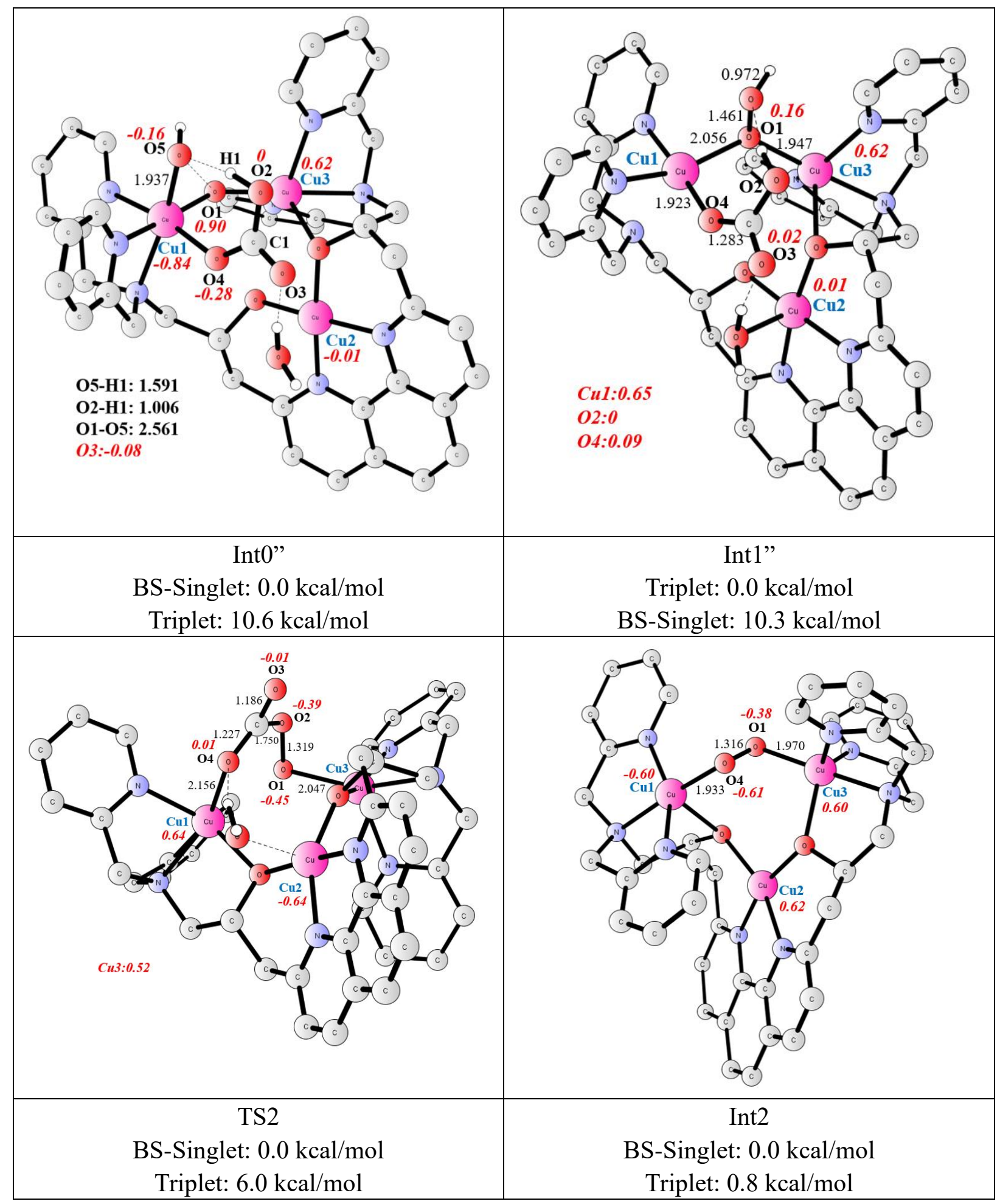




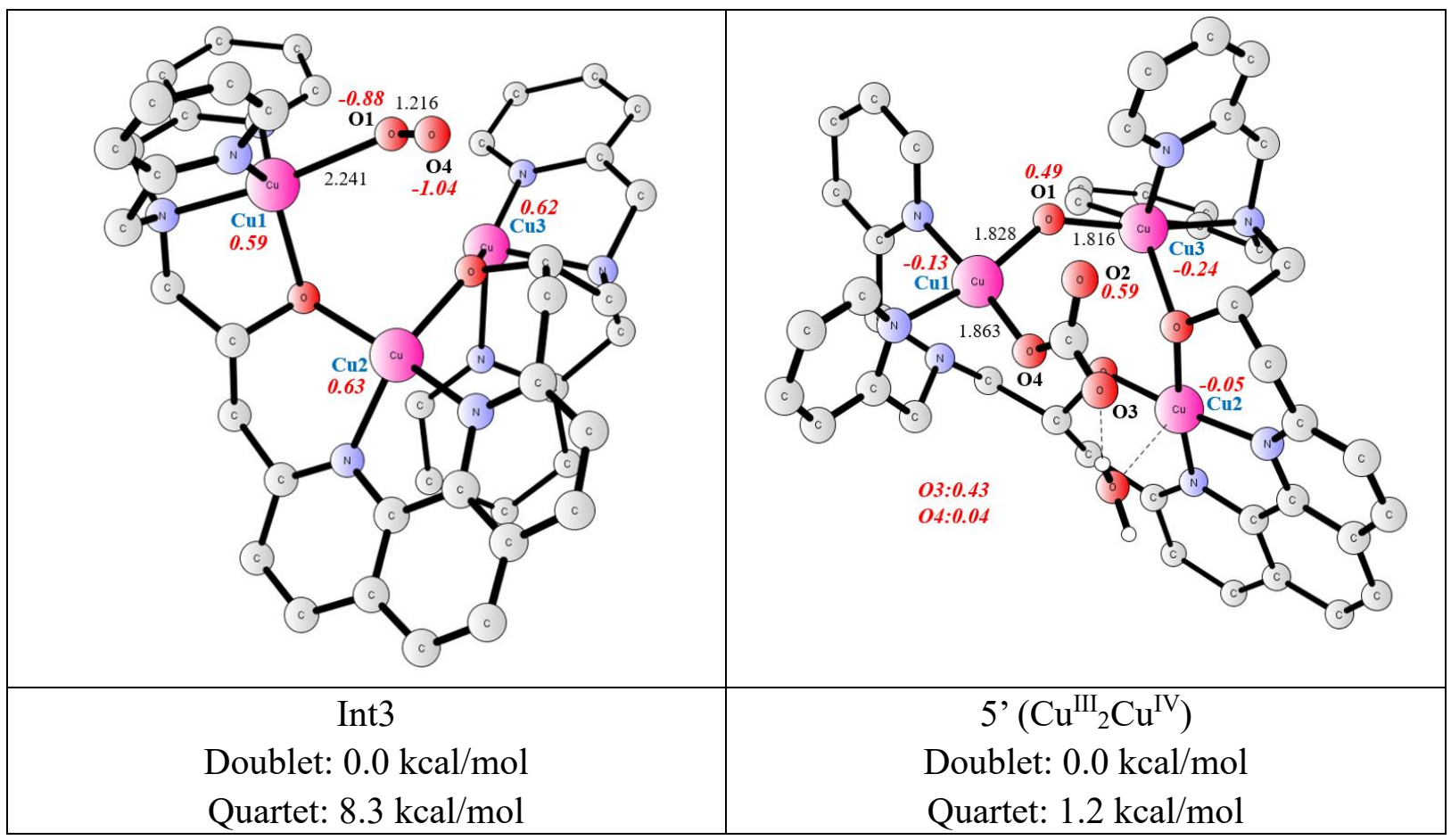




\section{Energies (in hartree) for all structures}

\begin{tabular}{|c|c|c|c|c|}
\hline & $\mathrm{E}(\mathrm{opt})$ & $\mathrm{E}(\mathrm{SMD})$ & $\begin{array}{l}\text { Gibbs free energy } \\
\text { corrections }\end{array}$ & $\begin{array}{l}\text { Dispersion } \\
\text { correction }\end{array}$ \\
\hline 1 & -2880.55793 & -2879.91597 & 0.69852 & -0.17137 \\
\hline $1 w$ & -2957.01021 & -2956.34224 & 0.72196 & -0.18432 \\
\hline 2 & -2880.03312 & -2879.71373 & 0.69898 & -0.17071 \\
\hline $2 \mathrm{dp}$ & -2879.87476 & -2879.23364 & 0.68747 & -0.16702 \\
\hline $2 w$ & -2956.49036 & -2956.14781 & 0.72584 & -0.17923 \\
\hline $2^{\prime}$ & -3221.36517 & -3220.67342 & 0.75022 & -0.20208 \\
\hline 3 & -2955.80375 & -2955.47395 & 0.71503 & -0.17778 \\
\hline $3^{\prime}$ & -3220.69663 & -3220.00662 & 0.73360 & -0.19731 \\
\hline 4 & -2955.11831 & -2954.79055 & 0.70196 & -0.17251 \\
\hline $4^{\prime}$ & -3220.01478 & -3219.32767 & 0.72202 & -0.19326 \\
\hline TS1 & -3220.00878 & -3219.32228 & 0.72127 & -0.18884 \\
\hline TS1' & -2955.10899 & -2954.78166 & 0.70147 & -0.17034 \\
\hline TSO" & -3296.45397 & -3295.75238 & 0.74328 & -0.20284 \\
\hline TS1" & -3296.44322 & -3295.73932 & 0.75107 & -0.20543 \\
\hline Int1 & -3220.04197 & -3219.36211 & 0.72627 & -0.19100 \\
\hline Int1' & -2955.14843 & -2954.81788 & 0.70324 & -0.16537 \\
\hline Int0" & -3296.45936 & -3295.75570 & 0.75031 & -0.20261 \\
\hline Int1" & -3296.48985 & -3295.78658 & 0.75289 & -0.20576 \\
\hline TS2 & -3220.04671 & -3219.35314 & 0.72289 & -0.19025 \\
\hline Int2 & -2955.04583 & -2954.40342 & 0.69148 & -0.16784 \\
\hline Int3 & -2954.52794 & -2954.21120 & 0.68447 & -0.16317 \\
\hline $5^{\prime}$ & -3219.48796 & -3219.10435 & 0.72385 & -0.19596 \\
\hline
\end{tabular}




\section{Cartesian coordinates for selected structures}

$1 \mathrm{Cu}_{3}(\mathrm{II}, \mathrm{II}, \mathrm{II})-\mathrm{OH}$ charge: +3

\begin{tabular}{|c|c|c|c|c|c|}
\hline \multirow{2}{*}{$\begin{array}{l}\text { Center } \\
\text { Number }\end{array}$} & \multirow{2}{*}{$\begin{array}{l}\text { Atomic } \\
\text { Number }\end{array}$} & \multirow{2}{*}{$\begin{array}{l}\text { Atomic } \\
\text { Type }\end{array}$} & \multicolumn{3}{|c|}{ Coordinates (Angstroms) } \\
\hline & & & $\mathrm{X}$ & $\mathrm{Y}$ & $\mathrm{Z}$ \\
\hline 1 & 29 & 0 & 1.404442 & -0.684167 & 0.432463 \\
\hline 2 & 29 & 0 & -0.691550 & 2.013252 & -0.029142 \\
\hline 3 & 29 & 0 & -2.196689 & -1.090539 & 0.211886 \\
\hline 4 & 8 & 0 & 0.452208 & 0.853816 & 1.205243 \\
\hline 5 & 8 & 0 & -0.182752 & -1.554516 & -0.228106 \\
\hline 6 & 8 & 0 & -2.215584 & 0.821262 & -0.127571 \\
\hline 7 & 7 & 0 & 3.166558 & -0.198603 & 1.285937 \\
\hline 8 & 7 & 0 & 2.626081 & -1.918416 & -0.668214 \\
\hline 9 & 7 & 0 & 0.810804 & 3.439020 & 0.215475 \\
\hline 10 & 7 & 0 & -1.802406 & 3.718248 & -0.320024 \\
\hline 11 & 7 & 0 & 0.536112 & 1.595941 & -1.841595 \\
\hline 12 & 7 & 0 & -2.318206 & -3.134042 & 0.399446 \\
\hline 13 & 7 & 0 & -2.437930 & -1.176862 & 2.284816 \\
\hline 14 & 7 & 0 & -3.644237 & -1.464837 & -1.229901 \\
\hline 15 & 6 & 0 & 3.360521 & 0.596796 & 2.341323 \\
\hline 16 & 6 & 0 & 4.669559 & 0.904007 & 2.772869 \\
\hline 17 & 6 & 0 & 5.762688 & 0.384359 & 2.103522 \\
\hline 18 & 6 & 0 & 5.567917 & -0.471605 & 0.993265 \\
\hline 19 & 6 & 0 & 6.625556 & -1.080958 & 0.236769 \\
\hline 20 & 6 & 0 & 6.349111 & -1.928958 & -0.798816 \\
\hline 21 & 6 & 0 & 4.993946 & -2.247236 & -1.152432 \\
\hline 22 & 6 & 0 & 4.622794 & -3.160647 & -2.168924 \\
\hline 23 & 6 & 0 & 3.288007 & -3.445211 & -2.378123 \\
\hline 24 & 6 & 0 & 2.290297 & -2.817200 & -1.595606 \\
\hline 25 & 6 & 0 & 4.229785 & -0.740479 & 0.633774 \\
\hline 26 & 6 & 0 & 3.939668 & -1.645992 & -0.434077 \\
\hline 27 & 6 & 0 & 2.127716 & 1.144334 & 3.009238 \\
\hline 28 & 6 & 0 & 1.134399 & 1.793458 & 2.026297 \\
\hline 29 & 6 & 0 & 1.817472 & 2.834870 & 1.128473 \\
\hline 30 & 6 & 0 & 0.133423 & 4.624646 & 0.802651 \\
\hline 31 & 6 & 0 & -1.196283 & 4.844095 & 0.116236 \\
\hline 32 & 6 & 0 & -1.777766 & 6.097221 & -0.050054 \\
\hline 33 & 6 & 0 & -3.021980 & 6.185007 & -0.678843 \\
\hline 34 & 6 & 0 & -3.638790 & 5.018820 & -1.136639 \\
\hline 35 & 6 & 0 & -2.991837 & 3.803235 & -0.941792 \\
\hline 36 & 6 & 0 & 1.379383 & 3.748800 & -1.125831 \\
\hline 37 & 6 & 0 & 1.524737 & 2.500726 & -1.972424 \\
\hline
\end{tabular}




\begin{tabular}{|c|c|c|c|c|c|}
\hline 38 & 6 & 0 & 2.574843 & 2.323788 & -2.871988 \\
\hline 39 & 6 & 0 & 2.582682 & 1.181170 & -3.676483 \\
\hline 40 & 6 & 0 & 1.548877 & 0.252349 & -3.547908 \\
\hline 41 & 6 & 0 & 0.546182 & 0.497774 & -2.611514 \\
\hline 42 & 6 & 0 & 0.832681 & -3.170499 & -1.754708 \\
\hline 43 & 6 & 0 & 0.011871 & -2.936876 & -0.477348 \\
\hline 44 & 6 & 0 & -1.350974 & -3.641439 & -0.608035 \\
\hline 45 & 6 & 0 & -1.979888 & -3.506759 & 1.797253 \\
\hline 46 & 6 & 0 & -2.426263 & -2.434853 & 2.770541 \\
\hline 47 & 6 & 0 & -2.732342 & -2.708616 & 4.101821 \\
\hline 48 & 6 & 0 & -3.041806 & -1.646469 & 4.953439 \\
\hline 49 & 6 & 0 & -3.032953 & -0.343634 & 4.449731 \\
\hline 50 & 6 & 0 & -2.728655 & -0.154729 & 3.105769 \\
\hline 51 & 6 & 0 & -3.720526 & -3.500824 & 0.059643 \\
\hline 52 & 6 & 0 & -4.208143 & -2.684409 & -1.116357 \\
\hline 53 & 6 & 0 & -5.186328 & -3.122935 & -2.003893 \\
\hline 54 & 6 & 0 & -5.593205 & -2.266001 & -3.029233 \\
\hline 55 & 6 & 0 & -5.002482 & -1.005152 & -3.142534 \\
\hline 56 & 6 & 0 & -4.025964 & -0.641891 & -2.220614 \\
\hline 57 & 1 & 0 & -3.002092 & 1.219638 & 0.268144 \\
\hline 58 & 1 & 0 & 4.805745 & 1.549126 & 3.633894 \\
\hline 59 & 1 & 0 & 6.770770 & 0.622920 & 2.430141 \\
\hline 60 & 1 & 0 & 7.653338 & -0.863056 & 0.509276 \\
\hline 61 & 1 & 0 & 7.155207 & -2.391771 & -1.359317 \\
\hline 62 & 1 & 0 & 5.389962 & -3.652798 & -2.759679 \\
\hline 63 & 1 & 0 & 2.990476 & -4.170495 & -3.128060 \\
\hline 64 & 1 & 0 & 2.412732 & 1.872610 & 3.773598 \\
\hline 65 & 1 & 0 & 1.599345 & 0.330856 & 3.520546 \\
\hline 66 & 1 & 0 & 0.376402 & 2.296627 & 2.646968 \\
\hline 67 & 1 & 0 & 2.338329 & 3.611563 & 1.702415 \\
\hline 68 & 1 & 0 & 2.551807 & 2.320331 & 0.505463 \\
\hline 69 & 1 & 0 & 0.768490 & 5.516727 & 0.740798 \\
\hline 70 & 1 & 0 & -0.038961 & 4.420259 & 1.864584 \\
\hline 71 & 1 & 0 & -1.266605 & 6.987075 & 0.302490 \\
\hline 72 & 1 & 0 & -3.496569 & 7.150952 & -0.819147 \\
\hline 73 & 1 & 0 & -4.597536 & 5.049937 & -1.641934 \\
\hline 74 & 1 & 0 & -3.408277 & 2.864585 & -1.290921 \\
\hline 75 & 1 & 0 & 2.334383 & 4.277638 & -1.024318 \\
\hline 76 & 1 & 0 & 0.683130 & 4.425278 & -1.632027 \\
\hline 77 & 1 & 0 & 3.360723 & 3.067873 & -2.952922 \\
\hline 78 & 1 & 0 & 3.380848 & 1.025021 & -4.395393 \\
\hline 79 & 1 & 0 & 1.518090 & -0.641246 & -4.161854 \\
\hline 80 & 1 & 0 & -0.263055 & -0.201657 & -2.432470 \\
\hline 81 & 1 & 0 & 0.763392 & -4.217310 & -2.071453 \\
\hline
\end{tabular}




$\begin{array}{rrrrrr}82 & 1 & 0 & 0.391070 & -2.568031 & -2.559296 \\ 83 & 1 & 0 & 0.560564 & -3.396422 & 0.361004 \\ 84 & 1 & 0 & -1.777310 & -3.420447 & -1.590001 \\ 85 & 1 & 0 & -1.235637 & -4.730004 & -0.523780 \\ 86 & 1 & 0 & -0.893148 & -3.596357 & 1.870424 \\ 87 & 1 & 0 & -2.401778 & -4.484948 & 2.055201 \\ 88 & 1 & 0 & -2.729874 & -3.731392 & 4.464699 \\ 89 & 1 & 0 & -3.290158 & -1.833998 & 5.993243 \\ 90 & 1 & 0 & -3.269276 & 0.505424 & 5.081355 \\ 91 & 1 & 0 & -2.709128 & 0.831071 & 2.652596 \\ 92 & 1 & 0 & -4.338751 & -3.269881 & 0.934438 \\ 93 & 1 & 0 & -3.808098 & -4.576960 & -0.132980 \\ 94 & 1 & 0 & -5.621813 & -4.110889 & -1.895438 \\ 95 & 1 & 0 & -6.356465 & -2.581731 & -3.733343 \\ 96 & 1 & 0 & -5.289959 & -0.319407 & -3.931697 \\ 97 & 1 & 0 & -3.516186 & 0.315300 & -2.244973\end{array}$

\section{$1_{\mathrm{w}} \mathrm{Cu}_{3}(\mathrm{II}, \mathrm{II}, \mathrm{II})-\mathrm{OH}-\mathrm{OH}_{2}$ charge: +3}

\begin{tabular}{rrrrrr} 
Center & Atomic & Atomic & \multicolumn{3}{c}{ Coordinates (Angstroms) } \\
Number & Number & Type & $\mathrm{X}$ & $\mathrm{Y}$ & $\mathrm{Z}$ \\
$-\mathrm{y}$ & 29 & 0 & 1.388768 & -0.740121 & 0.455127 \\
2 & 29 & 0 & -0.627933 & 2.058347 & 0.027236 \\
3 & 29 & 0 & -2.207029 & -1.020062 & 0.109185 \\
4 & 8 & 0 & 0.472995 & 0.856855 & 1.259618 \\
5 & 8 & 0 & -0.223919 & -1.467794 & -0.376069 \\
6 & 8 & 0 & -2.180022 & 0.908181 & -0.083479 \\
7 & 7 & 0 & 3.189308 & -0.245508 & 1.254707 \\
8 & 7 & 0 & 2.602506 & -1.906518 & -0.747569 \\
9 & 7 & 0 & 0.895132 & 3.452888 & 0.283558 \\
10 & 7 & 0 & -1.716585 & 3.795795 & -0.205881 \\
11 & 7 & 0 & 0.575862 & 1.666806 & -1.808655 \\
12 & 7 & 0 & -2.411578 & -3.058159 & 0.165517 \\
13 & 7 & 0 & -2.571395 & -1.241998 & 2.191194 \\
14 & 7 & 0 & -3.665947 & -1.241490 & -1.362204 \\
15 & 6 & 0 & 3.414450 & 0.530989 & 2.317923 \\
16 & 6 & 0 & 4.733216 & 0.819857 & 2.731372 \\
17 & 6 & 0 & 5.808514 & 0.302314 & 2.033416 \\
18 & 6 & 0 & 5.583621 & -0.528094 & 0.910751 \\
19 & 6 & 0 & 6.625072 & -1.121929 & 0.121388 \\
20 & 6 & 0 & 6.325525 & -1.935542 & -0.934187 \\
& & 0 & &
\end{tabular}




\begin{tabular}{|c|c|c|c|c|c|}
\hline 21 & 6 & 0 & 4.962677 & -2.231524 & -1.275698 \\
\hline 22 & 6 & 0 & 4.575665 & -3.101445 & -2.323295 \\
\hline 23 & 6 & 0 & 3.237353 & -3.362758 & -2.531323 \\
\hline 24 & 6 & 0 & 2.253529 & -2.757974 & -1.712884 \\
\hline 25 & 6 & 0 & 4.235503 & -0.780635 & 0.570598 \\
\hline 26 & 6 & 0 & 3.921302 & -1.652026 & -0.519996 \\
\hline 27 & 6 & 0 & 2.207057 & 1.094557 & 3.018374 \\
\hline 28 & 6 & 0 & 1.202778 & 1.772682 & 2.065130 \\
\hline 29 & 6 & 0 & 1.899920 & 2.799264 & 1.161177 \\
\hline 30 & 6 & 0 & 0.250764 & 4.634705 & 0.913019 \\
\hline 31 & 6 & 0 & -1.083804 & 4.897988 & 0.251588 \\
\hline 32 & 6 & 0 & -1.643259 & 6.165970 & 0.127033 \\
\hline 33 & 6 & 0 & -2.893966 & 6.293815 & -0.481592 \\
\hline 34 & 6 & 0 & -3.539477 & 5.151858 & -0.960382 \\
\hline 35 & 6 & 0 & -2.913061 & 3.919628 & -0.806736 \\
\hline 36 & 6 & 0 & 1.452834 & 3.792349 & -1.054644 \\
\hline 37 & 6 & 0 & 1.569386 & 2.566728 & -1.936400 \\
\hline 38 & 6 & 0 & 2.599761 & 2.407226 & -2.861240 \\
\hline 39 & 6 & 0 & 2.581774 & 1.287790 & -3.697337 \\
\hline 40 & 6 & 0 & 1.543086 & 0.364468 & -3.572415 \\
\hline 41 & 6 & 0 & 0.562013 & 0.590308 & -2.608581 \\
\hline 42 & 6 & 0 & 0.793756 & -3.083695 & -1.897313 \\
\hline 43 & 6 & 0 & -0.057063 & -2.852460 & -0.640869 \\
\hline 44 & 6 & 0 & -1.425528 & -3.527339 & -0.840989 \\
\hline 45 & 6 & 0 & -2.130875 & -3.531213 & 1.545335 \\
\hline 46 & 6 & 0 & -2.648746 & -2.538481 & 2.562985 \\
\hline 47 & 6 & 0 & -3.104911 & -2.911286 & 3.825268 \\
\hline 48 & 6 & 0 & -3.476414 & -1.914408 & 4.730230 \\
\hline 49 & 6 & 0 & -3.379986 & -0.574323 & 4.347265 \\
\hline 50 & 6 & 0 & -2.927207 & -0.283460 & 3.064231 \\
\hline 51 & 6 & 0 & -3.810711 & -3.368051 & -0.239802 \\
\hline 52 & 6 & 0 & -4.251519 & -2.455418 & -1.361136 \\
\hline 53 & 6 & 0 & -5.210481 & -2.806100 & -2.307054 \\
\hline 54 & 6 & 0 & -5.573826 & -1.864741 & -3.272821 \\
\hline 55 & 6 & 0 & -4.959605 & -0.610048 & -3.270663 \\
\hline 56 & 6 & 0 & -4.004365 & -0.337855 & -2.296501 \\
\hline 57 & 1 & 0 & -2.943874 & 1.301553 & 0.358406 \\
\hline 58 & 1 & 0 & 4.890951 & 1.451031 & 3.599101 \\
\hline 59 & 1 & 0 & 6.825039 & 0.525718 & 2.344112 \\
\hline 60 & 1 & 0 & 7.658356 & -0.917591 & 0.383369 \\
\hline 61 & 1 & 0 & 7.118371 & -2.385862 & -1.523104 \\
\hline 62 & 1 & 0 & 5.333480 & -3.574708 & -2.940883 \\
\hline 63 & 1 & 0 & 2.924255 & -4.050350 & -3.309929 \\
\hline 64 & 1 & 0 & 2.523826 & 1.811042 & 3.781332 \\
\hline
\end{tabular}




\begin{tabular}{|c|c|c|c|c|c|}
\hline 65 & 1 & 0 & 1.676341 & 0.289559 & 3.537847 \\
\hline 66 & 1 & 0 & 0.479063 & 2.297947 & 2.708719 \\
\hline 67 & 1 & 0 & 2.465892 & 3.547293 & 1.730939 \\
\hline 68 & 1 & 0 & 2.595338 & 2.264942 & 0.511188 \\
\hline 69 & 1 & 0 & 0.902826 & 5.515341 & 0.865117 \\
\hline 70 & 1 & 0 & 0.089220 & 4.406190 & 1.971615 \\
\hline 71 & 1 & 0 & -1.110338 & 7.036325 & 0.495675 \\
\hline 72 & 1 & 0 & -3.351742 & 7.271905 & -0.589960 \\
\hline 73 & 1 & 0 & -4.504652 & 5.214371 & -1.450319 \\
\hline 74 & 1 & 0 & -3.352841 & 2.997995 & -1.172161 \\
\hline 75 & 1 & 0 & 2.417089 & 4.303451 & -0.948736 \\
\hline 76 & 1 & 0 & 0.761460 & 4.493864 & -1.532679 \\
\hline 77 & 1 & 0 & 3.390067 & 3.147175 & -2.936716 \\
\hline 78 & 1 & 0 & 3.363977 & 1.145216 & -4.436326 \\
\hline 79 & 1 & 0 & 1.492690 & -0.512223 & -4.209023 \\
\hline 80 & 1 & 0 & -0.244409 & -0.110882 & -2.427958 \\
\hline 81 & 1 & 0 & 0.714969 & -4.126622 & -2.225380 \\
\hline 82 & 1 & 0 & 0.382482 & -2.469753 & -2.709394 \\
\hline 83 & 1 & 0 & 0.446186 & -3.332687 & 0.211586 \\
\hline 84 & 1 & 0 & -1.823711 & -3.250380 & -1.820937 \\
\hline 85 & 1 & 0 & -1.328904 & -4.620457 & -0.808410 \\
\hline 86 & 1 & 0 & -1.047491 & -3.585820 & 1.671539 \\
\hline 87 & 1 & 0 & -2.545253 & -4.532463 & 1.709145 \\
\hline 88 & 1 & 0 & -3.170169 & -3.960573 & 4.094350 \\
\hline 89 & 1 & 0 & -3.840894 & -2.180378 & 5.717465 \\
\hline 90 & 1 & 0 & -3.661351 & 0.226096 & 5.022514 \\
\hline 91 & 1 & 0 & -2.836537 & 0.736845 & 2.704740 \\
\hline 92 & 1 & 0 & -4.450476 & -3.193265 & 0.632408 \\
\hline 93 & 1 & 0 & -3.910808 & -4.424591 & -0.516162 \\
\hline 94 & 1 & 0 & -5.663963 & -3.791737 & -2.288750 \\
\hline 95 & 1 & 0 & -6.321058 & -2.110772 & -4.020569 \\
\hline 96 & 1 & 0 & -5.212295 & 0.139858 & -4.011920 \\
\hline 97 & 1 & 0 & -3.475791 & 0.607253 & -2.234080 \\
\hline 98 & 8 & 0 & 0.578600 & -1.930362 & 2.375412 \\
\hline 99 & 1 & 0 & -0.071094 & -1.231950 & 2.551160 \\
\hline 100 & 1 & 0 & 1.064545 & -2.072522 & 3.198284 \\
\hline
\end{tabular}

\section{$2 \mathrm{Cu}_{3}(\mathrm{II}, \mathrm{II}, \mathrm{III})-\mathrm{OH} \quad$ charge: +4}

$\begin{array}{lcccc}\text { Center } & \text { Atomic } & \text { Atomic } & \text { Coordinates (Angstroms) } & \\ \text { Number } & \text { Number } & \text { Type } & \text { X } & \text { Y } \\ - & - & & \end{array}$




\begin{tabular}{|c|c|c|c|c|c|}
\hline 1 & 29 & 0 & 1.686638 & -0.447246 & 0.547442 \\
\hline 2 & 29 & 0 & -1.116617 & 1.851921 & -0.797665 \\
\hline 3 & 29 & 0 & -2.067533 & -1.341388 & 0.202925 \\
\hline 4 & 8 & 0 & 0.452076 & 0.890835 & 0.925093 \\
\hline 5 & 8 & 0 & 0.270524 & -1.598686 & 0.173116 \\
\hline 6 & 8 & 0 & -2.233463 & 0.287062 & -0.821183 \\
\hline 7 & 7 & 0 & 3.225214 & 0.568741 & 1.164264 \\
\hline 8 & 7 & 0 & 3.036186 & -1.716423 & -0.113501 \\
\hline 9 & 7 & 0 & 0.165247 & 3.450543 & -0.637805 \\
\hline 10 & 7 & 0 & -2.531380 & 3.221096 & -0.325815 \\
\hline 11 & 7 & 0 & 0.198608 & 1.306200 & -2.242445 \\
\hline 12 & 7 & 0 & -1.813152 & -3.127039 & 1.145594 \\
\hline 13 & 7 & 0 & -2.308276 & -0.644398 & 2.092449 \\
\hline 14 & 7 & 0 & -3.088247 & -2.529706 & -1.128421 \\
\hline 15 & 6 & 0 & 3.236345 & 1.617662 & 1.991631 \\
\hline 16 & 6 & 0 & 4.464898 & 2.216758 & 2.350108 \\
\hline 17 & 6 & 0 & 5.661325 & 1.719077 & 1.863488 \\
\hline 18 & 6 & 0 & 5.660277 & 0.574509 & 1.029027 \\
\hline 19 & 6 & 0 & 6.829955 & -0.069849 & 0.501358 \\
\hline 20 & 6 & 0 & 6.727911 & -1.220823 & -0.233133 \\
\hline 21 & 6 & 0 & 5.450983 & -1.828574 & -0.484073 \\
\hline 22 & 6 & 0 & 5.252818 & -3.067376 & -1.144050 \\
\hline 23 & 6 & 0 & 3.979461 & -3.593982 & -1.236615 \\
\hline 24 & 6 & 0 & 2.865394 & -2.906787 & -0.696721 \\
\hline 25 & 6 & 0 & 4.399148 & 0.020783 & 0.726047 \\
\hline 26 & 6 & 0 & 4.295008 & -1.185839 & 0.000739 \\
\hline 27 & 6 & 0 & 1.911649 & 2.102542 & 2.510059 \\
\hline 28 & 6 & 0 & 0.863449 & 2.161427 & 1.390519 \\
\hline 29 & 6 & 0 & 1.316078 & 3.063440 & 0.226746 \\
\hline 30 & 6 & 0 & -0.570276 & 4.627719 & -0.080955 \\
\hline 31 & 6 & 0 & -2.064025 & 4.489164 & -0.257957 \\
\hline 32 & 6 & 0 & -2.921510 & 5.585528 & -0.260929 \\
\hline 33 & 6 & 0 & -4.299833 & 5.366290 & -0.318250 \\
\hline 34 & 6 & 0 & -4.779753 & 4.054291 & -0.369291 \\
\hline 35 & 6 & 0 & -3.863649 & 3.010438 & -0.379824 \\
\hline 36 & 6 & 0 & 0.586593 & 3.681507 & -2.054500 \\
\hline 37 & 6 & 0 & 0.896249 & 2.358426 & -2.721894 \\
\hline 38 & 6 & 0 & 1.792399 & 2.215236 & -3.777814 \\
\hline 39 & 6 & 0 & 1.952615 & 0.951577 & -4.352988 \\
\hline 40 & 6 & 0 & 1.229686 & -0.132366 & -3.843399 \\
\hline 41 & 6 & 0 & 0.358207 & 0.084814 & -2.780958 \\
\hline 42 & 6 & 0 & 1.488041 & -3.508659 & -0.728882 \\
\hline 43 & 6 & 0 & 0.597245 & -2.966610 & 0.388847 \\
\hline 44 & 6 & 0 & -0.697325 & -3.813152 & 0.446382 \\
\hline
\end{tabular}




\begin{tabular}{|c|c|c|c|c|c|}
\hline 45 & 6 & 0 & -1.564407 & -2.897210 & 2.597139 \\
\hline 46 & 6 & 0 & -2.172586 & -1.586811 & 3.049261 \\
\hline 47 & 6 & 0 & -2.514026 & -1.333680 & 4.375942 \\
\hline 48 & 6 & 0 & -2.995925 & -0.068473 & 4.717835 \\
\hline 49 & 6 & 0 & -3.120469 & 0.906351 & 3.723114 \\
\hline 50 & 6 & 0 & -2.771738 & 0.575727 & 2.418987 \\
\hline 51 & 6 & 0 & -3.110996 & -3.831818 & 0.911409 \\
\hline 52 & 6 & 0 & -3.545766 & -3.652336 & -0.527018 \\
\hline 53 & 6 & 0 & -4.371209 & -4.554051 & -1.191068 \\
\hline 54 & 6 & 0 & -4.740612 & -4.282809 & -2.511092 \\
\hline 55 & 6 & 0 & -4.255537 & -3.128724 & -3.133043 \\
\hline 56 & 6 & 0 & -3.428426 & -2.279118 & -2.407664 \\
\hline 57 & 1 & 0 & -3.001785 & 0.323805 & -1.403908 \\
\hline 58 & 1 & 0 & 4.453634 & 3.067976 & 3.022188 \\
\hline 59 & 1 & 0 & 6.601210 & 2.191006 & $2.13682 \varepsilon$ \\
\hline 60 & 1 & 0 & 7.803035 & 0.364148 & 0.709533 \\
\hline 61 & 1 & 0 & 7.620087 & -1.709918 & -0.611897 \\
\hline 62 & 1 & 0 & 6.102611 & -3.611620 & -1.546802 \\
\hline 63 & 1 & 0 & 3.814732 & -4.558937 & -1.704667 \\
\hline 64 & 1 & 0 & 2.027043 & 3.084231 & 2.975903 \\
\hline 65 & 1 & 0 & 1.554257 & 1.414425 & 3.285714 \\
\hline 66 & 1 & 0 & -0.045391 & 2.583034 & 1.851496 \\
\hline 67 & 1 & 0 & 1.827798 & 3.964568 & 0.585780 \\
\hline 68 & 1 & 0 & 2.022577 & 2.499164 & -0.385143 \\
\hline 69 & 1 & 0 & -0.195520 & 5.558046 & -0.520778 \\
\hline 70 & 1 & 0 & -0.360380 & 4.684219 & 0.992072 \\
\hline 71 & 1 & 0 & -2.520399 & 6.593155 & -0.216350 \\
\hline 72 & 1 & 0 & -4.987795 & 6.206155 & -0.324303 \\
\hline 73 & 1 & 0 & -5.842937 & 3.844673 & -0.411412 \\
\hline 74 & 1 & 0 & -4.176608 & 1.973901 & -0.427126 \\
\hline 75 & 1 & 0 & 1.438599 & 4.369477 & -2.101788 \\
\hline 76 & 1 & 0 & -0.252543 & 4.159238 & -2.572891 \\
\hline 77 & 1 & 0 & 2.340543 & 3.073357 & -4.153528 \\
\hline 78 & 1 & 0 & 2.629775 & 0.817055 & -5.190939 \\
\hline 79 & 1 & 0 & 1.328064 & -1.121935 & -4.276351 \\
\hline 80 & 1 & 0 & -0.233480 & -0.700720 & -2.324354 \\
\hline 81 & 1 & 0 & 1.580415 & -4.597991 & -0.663856 \\
\hline 82 & 1 & 0 & 1.014969 & -3.284726 & -1.694411 \\
\hline 83 & 1 & 0 & 1.119577 & -3.075428 & 1.351109 \\
\hline 84 & 1 & 0 & -1.037178 & -4.016199 & -0.570445 \\
\hline 85 & 1 & 0 & -0.470901 & -4.773953 & 0.926658 \\
\hline 86 & 1 & 0 & -0.484578 & -2.844731 & 2.757080 \\
\hline 87 & 1 & 0 & -1.933841 & -3.739538 & 3.191981 \\
\hline 88 & 1 & 0 & -2.413590 & -2.112118 & 5.125696 \\
\hline
\end{tabular}




$\begin{array}{rrrrrr}89 & 1 & 0 & -3.279828 & 0.149212 & 5.742831 \\ 90 & 1 & 0 & -3.503123 & 1.894813 & 3.952654 \\ 91 & 1 & 0 & -2.864879 & 1.273399 & 1.594937 \\ 92 & 1 & 0 & -3.851149 & -3.377080 & 1.579363 \\ 93 & 1 & 0 & -3.032113 & -4.892619 & 1.177325 \\ 94 & 1 & 0 & -4.721365 & -5.449306 & -0.687154 \\ 95 & 1 & 0 & -5.389280 & -4.967343 & -3.048898 \\ 96 & 1 & 0 & -4.510901 & -2.893792 & -4.160499 \\ 97 & 1 & 0 & -3.010022 & -1.378550 & -2.845531\end{array}$

\section{$2_{\mathrm{dp}} \mathrm{Cu}_{3}(\mathrm{II}, \mathrm{II}, \mathrm{III})-\mathrm{O}$ charge: +3}

\begin{tabular}{|c|c|c|c|c|c|}
\hline \multirow{2}{*}{$\begin{array}{l}\text { Center } \\
\text { Number }\end{array}$} & \multirow{2}{*}{$\begin{array}{l}\text { Atomic } \\
\text { Number }\end{array}$} & \multirow{2}{*}{$\begin{array}{l}\text { Atomic } \\
\text { Type }\end{array}$} & \multicolumn{3}{|c|}{ Coordinates (Angstroms) } \\
\hline & & & $\mathrm{X}$ & $\mathrm{Y}$ & $\mathrm{Z}$ \\
\hline 1 & 29 & 0 & 1.475860 & -0.619951 & 0.549708 \\
\hline 2 & 29 & 0 & -0.707059 & 1.892410 & -0.364923 \\
\hline 3 & 29 & 0 & -2.083639 & -1.151341 & 0.092644 \\
\hline 4 & 8 & 0 & 0.445033 & 0.942597 & 1.109649 \\
\hline 5 & 8 & 0 & -0.066723 & -1.630665 & -0.036826 \\
\hline 6 & 8 & 0 & -2.006229 & 0.547718 & -0.664798 \\
\hline 7 & 7 & 0 & 3.203878 & 0.054511 & 1.320377 \\
\hline 8 & 7 & 0 & 2.749633 & -1.955957 & -0.361103 \\
\hline 9 & 7 & 0 & 0.596067 & 3.477648 & -0.112294 \\
\hline 10 & 7 & 0 & -2.071544 & 3.414212 & -0.479823 \\
\hline 11 & 7 & 0 & 0.661645 & 1.470492 & -1.976243 \\
\hline 12 & 7 & 0 & -2.194788 & -3.092511 & 0.754048 \\
\hline 13 & 7 & 0 & -2.554504 & -0.759932 & 2.097261 \\
\hline 14 & 7 & 0 & -3.559811 & -1.834660 & -1.197612 \\
\hline 15 & 6 & 0 & 3.354753 & 0.998955 & 2.252558 \\
\hline 16 & 6 & 0 & 4.646321 & 1.433959 & 2.622947 \\
\hline 17 & 6 & 0 & 5.764672 & 0.881006 & 2.025637 \\
\hline 18 & 6 & 0 & 5.615059 & -0.137240 & 1.053719 \\
\hline 19 & 6 & 0 & 6.702896 & -0.799732 & 0.390641 \\
\hline 20 & 6 & 0 & 6.470401 & -1.806489 & -0.504068 \\
\hline 21 & 6 & 0 & 5.133267 & -2.240081 & -0.798919 \\
\hline 22 & 6 & 0 & 4.810316 & -3.313709 & -1.664100 \\
\hline 23 & 6 & 0 & 3.491574 & -3.689939 & -1.823733 \\
\hline 24 & 6 & 0 & 2.461212 & -2.998879 & -1.142945 \\
\hline 25 & 6 & 0 & 4.292786 & -0.522206 & 0.745109 \\
\hline 26 & 6 & 0 & 4.048784 & -1.589353 & -0.174918 \\
\hline 27 & 6 & 0 & 2.094784 & 1.552108 & 2.862667 \\
\hline
\end{tabular}




\begin{tabular}{|c|c|c|c|c|c|}
\hline 28 & 6 & 0 & 1.051022 & 2.008323 & 1.824171 \\
\hline 29 & 6 & 0 & 1.653036 & 3.009948 & 0.826350 \\
\hline 30 & 6 & 0 & -0.187334 & 4.620278 & 0.430573 \\
\hline 31 & 6 & 0 & -1.582463 & 4.629293 & -0.151910 \\
\hline 32 & 6 & 0 & -2.342945 & 5.784764 & -0.301141 \\
\hline 33 & 6 & 0 & -3.647256 & 5.673171 & -0.789199 \\
\hline 34 & 6 & 0 & -4.147380 & 4.412360 & -1.121275 \\
\hline 35 & 6 & 0 & -3.324204 & 3.302986 & -0.959007 \\
\hline 36 & 6 & 0 & 1.133057 & 3.785567 & -1.468504 \\
\hline 37 & 6 & 0 & 1.478799 & 2.514408 & -2.214815 \\
\hline 38 & 6 & 0 & 2.540909 & 2.424945 & -3.112369 \\
\hline 39 & 6 & 0 & 2.748531 & 1.219437 & -3.787470 \\
\hline 40 & 6 & 0 & 1.899879 & 0.139947 & -3.532948 \\
\hline 41 & 6 & 0 & 0.866353 & 0.307178 & -2.614612 \\
\hline 42 & 6 & 0 & 1.022209 & -3.440991 & -1.253907 \\
\hline 43 & 6 & 0 & 0.166749 & -3.032535 & -0.047774 \\
\hline 44 & 6 & 0 & -1.176943 & -3.786332 & -0.076746 \\
\hline 45 & 6 & 0 & -1.897551 & -3.090564 & 2.209441 \\
\hline 46 & 6 & 0 & -2.483674 & -1.859828 & 2.873694 \\
\hline 47 & 6 & 0 & -2.869309 & -1.835770 & 4.212168 \\
\hline 48 & 6 & 0 & -3.327188 & -0.635156 & 4.758623 \\
\hline 49 & 6 & 0 & -3.387715 & 0.503103 & 3.951346 \\
\hline 50 & 6 & 0 & -2.995028 & 0.395940 & 2.621045 \\
\hline 51 & 6 & 0 & -3.572387 & -3.579549 & 0.472571 \\
\hline 52 & 6 & 0 & -4.075697 & -3.029386 & -0.843477 \\
\hline 53 & 6 & 0 & -5.040885 & -3.666354 & -1.617849 \\
\hline 54 & 6 & 0 & -5.489259 & -3.037558 & -2.781675 \\
\hline 55 & 6 & 0 & -4.954922 & -1.797425 & -3.138620 \\
\hline 56 & 6 & 0 & -3.986074 & -1.228091 & -2.318406 \\
\hline 57 & 1 & 0 & 4.749398 & 2.200348 & 3.383275 \\
\hline 58 & 1 & 0 & 6.759037 & 1.215692 & 2.306813 \\
\hline 59 & 1 & 0 & 7.718224 & -0.493628 & 0.621916 \\
\hline 60 & 1 & 0 & 7.299393 & -2.308837 & -0.992500 \\
\hline 61 & 1 & 0 & 5.602403 & -3.852195 & -2.176325 \\
\hline 62 & 1 & 0 & 3.232079 & -4.533232 & -2.455019 \\
\hline 63 & 1 & 0 & 2.338804 & 2.386908 & 3.525657 \\
\hline 64 & 1 & 0 & 1.625816 & 0.777455 & 3.481085 \\
\hline 65 & 1 & 0 & 0.254949 & 2.508986 & 2.397121 \\
\hline 66 & 1 & 0 & 2.131468 & 3.864086 & 1.321983 \\
\hline 67 & 1 & 0 & 2.408731 & 2.490557 & 0.233416 \\
\hline 68 & 1 & 0 & 0.330603 & 5.570303 & 0.253723 \\
\hline 69 & 1 & 0 & -0.261323 & 4.490368 & 1.514839 \\
\hline 70 & 1 & 0 & -1.924798 & 6.751745 & -0.041135 \\
\hline 71 & 1 & 0 & -4.260755 & 6.559741 & -0.914341 \\
\hline
\end{tabular}




\begin{tabular}{|c|c|c|c|c|c|}
\hline 72 & 1 & 0 & -5.152967 & 4.290084 & -1.507753 \\
\hline 73 & 1 & 0 & -3.637116 & 2.295974 & -1.210830 \\
\hline 74 & 1 & 0 & 1.997359 & 4.456442 & -1.397173 \\
\hline 75 & 1 & 0 & 0.347925 & 4.314719 & -2.019494 \\
\hline 76 & 1 & 0 & 3.186687 & 3.279684 & -3.285553 \\
\hline 77 & 1 & 0 & 3.561671 & 1.126845 & -4.500515 \\
\hline 78 & 1 & 0 & 2.033102 & -0.810549 & -4.037921 \\
\hline 79 & 1 & 0 & 0.190903 & -0.497466 & -2.342997 \\
\hline 80 & 1 & 0 & 1.004010 & -4.528596 & -1.388577 \\
\hline 81 & 1 & 0 & 0.569688 & -3.005708 & -2.155394 \\
\hline 82 & 1 & 0 & 0.708314 & -3.324962 & 0.865982 \\
\hline 83 & 1 & 0 & -1.567732 & -3.796664 & -1.098307 \\
\hline 84 & 1 & 0 & -1.046930 & -4.827182 & 0.247531 \\
\hline 85 & 1 & 0 & -0.812375 & -3.057150 & 2.332082 \\
\hline 86 & 1 & 0 & -2.252521 & -4.011852 & 2.685668 \\
\hline 87 & 1 & 0 & -2.816577 & -2.737725 & 4.813362 \\
\hline 88 & 1 & 0 & -3.639921 & -0.591832 & 5.797072 \\
\hline 89 & 1 & 0 & -3.746231 & 1.449668 & 4.340304 \\
\hline 90 & 1 & 0 & -3.031287 & 1.239385 & 1.938874 \\
\hline 91 & 1 & 0 & -4.219607 & -3.210470 & 1.275776 \\
\hline 92 & 1 & 0 & -3.612221 & -4.675174 & 0.494502 \\
\hline 93 & 1 & 0 & -5.436673 & -4.630521 & -1.315762 \\
\hline 94 & 1 & 0 & -6.243185 & -3.511582 & -3.402079 \\
\hline 95 & 1 & 0 & -5.278972 & -1.282996 & -4.036364 \\
\hline 96 & 1 & 0 & -3.524673 & -0.269986 & -2.532116 \\
\hline
\end{tabular}

\section{$2_{\mathrm{w}} \quad \mathrm{Cu}_{3}(\mathrm{II}, \mathrm{II}, \mathrm{III})-\mathrm{OH}-\mathrm{OH}_{2} \quad$ charge: +4}

\begin{tabular}{|c|c|c|c|c|c|}
\hline \multirow{2}{*}{$\begin{array}{l}\text { Center } \\
\text { Number }\end{array}$} & \multirow{2}{*}{$\begin{array}{l}\text { Atomic } \\
\text { Number }\end{array}$} & \multirow{2}{*}{$\begin{array}{l}\text { Atomic } \\
\text { Type }\end{array}$} & \multicolumn{3}{|c|}{ Coordinates (Angstroms) } \\
\hline & & & $\mathrm{X}$ & $\mathrm{Y}$ & $\mathrm{Z}$ \\
\hline 1 & 29 & 0 & -1.948143 & -0.627749 & -0.490551 \\
\hline 2 & 29 & 0 & 0.364424 & 2.075347 & 0.944556 \\
\hline 3 & 29 & 0 & 2.765429 & -0.336711 & -0.302942 \\
\hline 4 & 8 & 0 & -0.966930 & 0.915618 & -0.888021 \\
\hline 5 & 8 & 0 & -0.368375 & -1.314612 & 0.129637 \\
\hline 6 & 8 & 0 & 1.861408 & 0.830377 & 0.989608 \\
\hline 7 & 7 & 0 & -3.591741 & -0.000108 & -1.342235 \\
\hline 8 & 7 & 0 & -3.025659 & -2.122916 & 0.106411 \\
\hline 9 & 7 & 0 & -1.278266 & 3.373575 & 0.848210 \\
\hline 10 & 7 & 0 & 1.238748 & 3.476479 & -0.189508 \\
\hline 11 & 7 & 0 & -0.700068 & 1.271983 & 2.439881 \\
\hline
\end{tabular}




\begin{tabular}{|c|c|c|c|c|c|}
\hline 12 & 7 & 0 & 2.328872 & -2.618383 & 0.000455 \\
\hline 13 & 7 & 0 & 3.767204 & -1.205421 & -1.860369 \\
\hline 14 & 7 & 0 & 4.201007 & -0.758310 & 1.048394 \\
\hline 15 & 6 & 0 & -3.767281 & 1.046975 & -2.154010 \\
\hline 16 & 6 & 0 & -5.041733 & 1.298727 & -2.712997 \\
\hline 17 & 6 & 0 & -6.109039 & 0.460151 & -2.448217 \\
\hline 18 & 6 & 0 & -5.922556 & -0.674419 & -1.620511 \\
\hline 19 & 6 & 0 & -6.939202 & -1.630821 & -1.285137 \\
\hline 20 & 6 & 0 & -6.655921 & -2.709146 & -0.490716 \\
\hline 21 & 6 & 0 & -5.332711 & -2.921192 & 0.024780 \\
\hline 22 & 6 & 0 & -4.937030 & -4.019258 & 0.827909 \\
\hline 23 & 6 & 0 & -3.623962 & -4.124815 & 1.244415 \\
\hline 24 & 6 & 0 & -2.662025 & -3.154513 & 0.874011 \\
\hline 25 & 6 & 0 & -4.626478 & -0.862002 & -1.098900 \\
\hline 26 & 6 & 0 & -4.328331 & -1.987313 & -0.299109 \\
\hline 27 & 6 & 0 & -2.573723 & 1.899610 & -2.489115 \\
\hline 28 & 6 & 0 & -1.608953 & 2.110545 & -1.317428 \\
\hline 29 & 6 & 0 & -2.269834 & 2.805225 & -0.116330 \\
\hline 30 & 6 & 0 & -0.770129 & 4.712767 & 0.417290 \\
\hline 31 & 6 & 0 & 0.520980 & 4.608922 & -0.363906 \\
\hline 32 & 6 & 0 & 0.993519 & 5.658667 & -1.147301 \\
\hline 33 & 6 & 0 & 2.249175 & 5.543222 & -1.746014 \\
\hline 34 & 6 & 0 & 2.992709 & 4.376233 & -1.548048 \\
\hline 35 & 6 & 0 & 2.450698 & 3.363543 & -0.768448 \\
\hline 36 & 6 & 0 & -1.844975 & 3.396785 & 2.230473 \\
\hline 37 & 6 & 0 & -1.728598 & 2.033726 & 2.874977 \\
\hline 38 & 6 & 0 & -2.556086 & 1.612001 & 3.912706 \\
\hline 39 & 6 & 0 & -2.288161 & 0.389320 & 4.532910 \\
\hline 40 & 6 & 0 & -1.215438 & -0.386104 & 4.081194 \\
\hline 41 & 6 & 0 & -0.449339 & 0.085093 & 3.021290 \\
\hline 42 & 6 & 0 & -1.238952 & -3.247202 & 1.344145 \\
\hline 43 & 6 & 0 & -0.243671 & -2.701415 & 0.307538 \\
\hline 44 & 6 & 0 & 1.182087 & -3.026858 & 0.830652 \\
\hline 45 & 6 & 0 & 2.246724 & -3.057101 & -1.410091 \\
\hline 46 & 6 & 0 & 3.389777 & -2.457788 & -2.207505 \\
\hline 47 & 6 & 0 & 4.027725 & -3.143640 & -3.237681 \\
\hline 48 & 6 & 0 & 5.072984 & -2.522758 & -3.927086 \\
\hline 49 & 6 & 0 & 5.460796 & -1.233080 & -3.557852 \\
\hline 50 & 6 & 0 & 4.783794 & -0.609463 & -2.515293 \\
\hline 51 & 6 & 0 & 3.586353 & -3.105273 & 0.638616 \\
\hline 52 & 6 & 0 & 4.355383 & -2.048210 & 1.407444 \\
\hline 53 & 6 & 0 & 5.276473 & -2.412636 & 2.391305 \\
\hline 54 & 6 & 0 & 6.063514 & -1.431631 & 2.993139 \\
\hline 55 & 6 & 0 & 5.903908 & -0.097941 & 2.604159 \\
\hline
\end{tabular}




\begin{tabular}{|c|c|c|c|c|c|}
\hline 56 & 6 & 0 & 4.955876 & 0.197648 & 1.634729 \\
\hline 57 & 1 & 0 & -5.164910 & 2.157547 & -3.364026 \\
\hline 58 & 1 & 0 & -7.084958 & 0.662587 & -2.880895 \\
\hline 59 & 1 & 0 & -7.941348 & -1.485399 & -1.676336 \\
\hline 60 & 1 & 0 & -7.430370 & -3.429988 & -0.247533 \\
\hline 61 & 1 & 0 & -5.663521 & -4.776753 & 1.108967 \\
\hline 62 & 1 & 0 & -3.307356 & -4.959893 & 1.859880 \\
\hline 63 & 1 & 0 & -2.908152 & 2.866906 & -2.873853 \\
\hline 64 & 1 & 0 & -2.023246 & 1.412687 & -3.304434 \\
\hline 65 & 1 & 0 & -0.799876 & 2.744034 & -1.705229 \\
\hline 66 & 1 & 0 & -2.953267 & 3.598476 & -0.442829 \\
\hline 67 & 1 & 0 & -2.860028 & 2.056406 & 0.418694 \\
\hline 68 & 1 & 0 & -0.568925 & 5.308054 & 1.313263 \\
\hline 69 & 1 & 0 & -1.531846 & 5.256335 & -0.151904 \\
\hline 70 & 1 & 0 & 0.397765 & 6.557454 & -1.272285 \\
\hline 71 & 1 & 0 & 2.642653 & 6.353333 & -2.352218 \\
\hline 72 & 1 & 0 & 3.976078 & 4.257674 & -1.989113 \\
\hline 73 & 1 & 0 & 2.963524 & 2.430643 & -0.579033 \\
\hline 74 & 1 & 0 & -2.879601 & 3.758337 & 2.232865 \\
\hline 75 & 1 & 0 & -1.256328 & 4.100619 & 2.827103 \\
\hline 76 & 1 & 0 & -3.375962 & 2.239596 & 4.247287 \\
\hline 77 & 1 & 0 & -2.901616 & 0.052800 & 5.363120 \\
\hline 78 & 1 & 0 & -0.969097 & -1.329663 & 4.556375 \\
\hline 79 & 1 & 0 & 0.381817 & -0.462336 & 2.595672 \\
\hline 80 & 1 & 0 & -1.015420 & -4.288276 & 1.591066 \\
\hline 81 & 1 & 0 & -1.142987 & -2.663101 & 2.268509 \\
\hline 82 & 1 & 0 & -0.399902 & -3.234033 & -0.642690 \\
\hline 83 & 1 & 0 & 1.311113 & -2.555652 & 1.810083 \\
\hline 84 & 1 & 0 & 1.193213 & -4.118264 & 0.979831 \\
\hline 85 & 1 & 0 & 1.301670 & -2.686722 & -1.821148 \\
\hline 86 & 1 & 0 & 2.248898 & -4.151038 & -1.515304 \\
\hline 87 & 1 & 0 & 3.719172 & -4.152903 & -3.490631 \\
\hline 88 & 1 & 0 & 5.585007 & -3.044021 & -4.730005 \\
\hline 89 & 1 & 0 & 6.276418 & -0.722715 & -4.058186 \\
\hline 90 & 1 & 0 & 5.054080 & 0.386262 & -2.179088 \\
\hline 91 & 1 & 0 & 4.254473 & -3.477757 & -0.144741 \\
\hline 92 & 1 & 0 & 3.390952 & -3.962636 & 1.292897 \\
\hline 93 & 1 & 0 & 5.383090 & -3.455995 & 2.671503 \\
\hline 94 & 1 & 0 & 6.790775 & -1.701659 & 3.752532 \\
\hline 95 & 1 & 0 & 6.499584 & 0.695008 & 3.042742 \\
\hline 96 & 1 & 0 & 4.780277 & 1.215904 & 1.302444 \\
\hline 97 & 8 & 0 & 1.489093 & 0.420935 & -1.701974 \\
\hline 98 & 1 & 0 & 0.534335 & 0.512529 & -1.431054 \\
\hline 99 & 1 & 0 & 1.534736 & 0.043412 & -2.590103 \\
\hline
\end{tabular}




\section{2' $\mathrm{Cu}_{3}(\mathrm{II}, \mathrm{II}, \mathrm{III})-\mathrm{OH}-\mathrm{OH}_{2}-\mathrm{HCO}_{3}$ charge: +3}

\begin{tabular}{|c|c|c|c|c|c|}
\hline \multirow{2}{*}{$\begin{array}{l}\text { Center } \\
\text { Number }\end{array}$} & \multirow{2}{*}{$\begin{array}{l}\text { Atomic } \\
\text { Number }\end{array}$} & \multirow{2}{*}{$\begin{array}{l}\text { Atomic } \\
\text { Type }\end{array}$} & \multicolumn{3}{|c|}{ Coordinates (Angstroms) } \\
\hline & & & $\mathrm{X}$ & $\mathrm{Y}$ & $\mathrm{Z}$ \\
\hline 1 & 29 & 0 & -1.967467 & -0.645411 & -0.128945 \\
\hline 2 & 29 & 0 & 0.411908 & 2.053185 & 0.249796 \\
\hline 3 & 29 & 0 & 2.668456 & -0.545746 & -0.715435 \\
\hline 4 & 8 & 0 & -1.077418 & 0.866670 & -0.794361 \\
\hline 5 & 8 & 0 & -0.453343 & -0.933793 & 0.855224 \\
\hline 6 & 8 & 0 & 2.098259 & 1.372584 & -0.442032 \\
\hline 7 & 7 & 0 & -3.683161 & -0.213499 & -0.963509 \\
\hline 8 & 7 & 0 & -3.029398 & -1.917777 & 0.949559 \\
\hline 9 & 7 & 0 & -1.382946 & 2.954294 & 0.834537 \\
\hline 10 & 7 & 0 & 0.656815 & 3.952665 & -0.605897 \\
\hline 11 & 7 & 0 & 0.534719 & 1.599568 & 2.239535 \\
\hline 12 & 7 & 0 & 2.276943 & -2.426246 & 0.628591 \\
\hline 13 & 7 & 0 & 3.615350 & -2.066579 & -1.759218 \\
\hline 14 & 7 & 0 & 4.203453 & -0.350748 & 0.617860 \\
\hline 15 & 6 & 0 & -3.920920 & 0.645129 & -1.955433 \\
\hline 16 & 6 & 0 & -5.223008 & 0.739581 & -2.507057 \\
\hline 17 & 6 & 0 & -6.248169 & -0.054256 & -2.035694 \\
\hline 18 & 6 & 0 & -6.000297 & -0.972388 & -0.985211 \\
\hline 19 & 6 & 0 & -6.982401 & -1.842645 & -0.404157 \\
\hline 20 & 6 & 0 & -6.652580 & -2.699590 & 0.609995 \\
\hline 21 & 6 & 0 & -5.312561 & -2.759591 & 1.119470 \\
\hline 22 & 6 & 0 & -4.873356 & -3.623603 & 2.152345 \\
\hline 23 & 6 & 0 & -3.549854 & -3.605683 & 2.541499 \\
\hline 24 & 6 & 0 & -2.620718 & -2.735398 & 1.918499 \\
\hline 25 & 6 & 0 & -4.683059 & -1.014828 & -0.486738 \\
\hline 26 & 6 & 0 & -4.337008 & -1.913854 & 0.553819 \\
\hline 27 & 6 & 0 & -2.781301 & 1.469128 & -2.472195 \\
\hline 28 & 6 & 0 & -1.794257 & 1.922458 & -1.393531 \\
\hline 29 & 6 & 0 & -2.380711 & 2.821146 & -0.284351 \\
\hline 30 & 6 & 0 & -1.001139 & 4.367714 & 1.097251 \\
\hline 31 & 6 & 0 & -0.150951 & 4.878947 & -0.043488 \\
\hline 32 & 6 & 0 & -0.162839 & 6.200646 & -0.476470 \\
\hline 33 & 6 & 0 & 0.691549 & 6.575913 & -1.516762 \\
\hline 34 & 6 & 0 & 1.523157 & 5.615842 & -2.095354 \\
\hline 35 & 6 & 0 & 1.473604 & 4.312199 & -1.611085 \\
\hline
\end{tabular}




\begin{tabular}{|c|c|c|c|c|c|}
\hline 36 & 6 & 0 & -1.796118 & 2.243527 & 2.071473 \\
\hline 37 & 6 & 0 & -0.605334 & 1.836426 & 2.915014 \\
\hline 38 & 6 & 0 & -0.689991 & 1.633065 & 4.291198 \\
\hline 39 & 6 & 0 & 0.432385 & 1.156087 & 4.971429 \\
\hline 40 & 6 & 0 & 1.606107 & 0.899484 & 4.257629 \\
\hline 41 & 6 & 0 & 1.616589 & 1.141450 & 2.888176 \\
\hline 42 & 6 & 0 & -1.173140 & -2.717914 & 2.331987 \\
\hline 43 & 6 & 0 & -0.238218 & -2.275389 & 1.194330 \\
\hline 44 & 6 & 0 & 1.223229 & -2.451887 & 1.663281 \\
\hline 45 & 6 & 0 & 2.061413 & -3.417634 & -0.452960 \\
\hline 46 & 6 & 0 & 3.127295 & -3.300654 & -1.523395 \\
\hline 47 & 6 & 0 & 3.565106 & -4.401152 & -2.256935 \\
\hline 48 & 6 & 0 & 4.509042 & -4.213408 & -3.267827 \\
\hline 49 & 6 & 0 & 5.003599 & -2.930712 & -3.507965 \\
\hline 50 & 6 & 0 & 4.531126 & -1.882459 & -2.725394 \\
\hline 51 & 6 & 0 & 3.589342 & -2.622941 & 1.292988 \\
\hline 52 & 6 & 0 & 4.360561 & -1.340979 & 1.519932 \\
\hline 53 & 6 & 0 & 5.290922 & -1.230878 & 2.556167 \\
\hline 54 & 6 & 0 & 6.097182 & -0.097197 & 2.639536 \\
\hline 55 & 6 & 0 & 5.957442 & 0.905420 & 1.675942 \\
\hline 56 & 6 & 0 & 4.996230 & 0.737969 & 0.688183 \\
\hline 57 & 1 & 0 & -5.394609 & 1.444545 & -3.312883 \\
\hline 58 & 1 & 0 & -7.243241 & 0.021156 & -2.464429 \\
\hline 59 & 1 & 0 & -7.997905 & -1.808261 & -0.785657 \\
\hline 60 & 1 & 0 & -7.402709 & -3.354870 & 1.041118 \\
\hline 61 & 1 & 0 & -5.577317 & -4.300633 & 2.627359 \\
\hline 62 & 1 & 0 & -3.197038 & -4.265051 & 3.327055 \\
\hline 63 & 1 & 0 & -3.166882 & 2.334749 & -3.018265 \\
\hline 64 & 1 & 0 & -2.196583 & 0.860874 & -3.178054 \\
\hline 65 & 1 & 0 & -1.035452 & 2.494458 & -1.946366 \\
\hline 66 & 1 & 0 & -2.621643 & 3.810737 & -0.680398 \\
\hline 67 & 1 & 0 & -3.304160 & 2.391979 & 0.115371 \\
\hline 68 & 1 & 0 & -0.412339 & 4.385113 & 2.021449 \\
\hline 69 & 1 & 0 & -1.885834 & 4.995304 & 1.255755 \\
\hline 70 & 1 & 0 & -0.825848 & 6.922470 & -0.010803 \\
\hline 71 & 1 & 0 & 0.701224 & 7.600884 & -1.873610 \\
\hline 72 & 1 & 0 & 2.192466 & 5.866365 & -2.910712 \\
\hline 73 & 1 & 0 & 2.087724 & 3.523984 & -2.030431 \\
\hline 74 & 1 & 0 & -2.300808 & 1.324160 & 1.761038 \\
\hline 75 & 1 & 0 & -2.513406 & 2.838162 & 2.650410 \\
\hline 76 & 1 & 0 & -1.612294 & 1.849143 & 4.820742 \\
\hline 77 & 1 & 0 & 0.393898 & 0.996967 & 6.044481 \\
\hline 78 & 1 & 0 & 2.499158 & 0.535633 & 4.753417 \\
\hline 79 & 1 & 0 & 2.492515 & 0.966384 & 2.273217 \\
\hline
\end{tabular}




\begin{tabular}{|c|c|c|c|c|c|}
\hline 80 & 1 & 0 & -0.910651 & -3.715521 & 2.696733 \\
\hline 81 & 1 & 0 & -1.056878 & -2.024623 & 3.176821 \\
\hline 82 & 1 & 0 & -0.412354 & -2.915995 & 0.320487 \\
\hline 83 & 1 & 0 & 1.448660 & -1.661778 & 2.386638 \\
\hline 84 & 1 & 0 & 1.266144 & -3.414917 & 2.197336 \\
\hline 85 & 1 & 0 & 1.103538 & -3.187767 & -0.926878 \\
\hline 86 & 1 & 0 & 2.029412 & -4.446774 & -0.066490 \\
\hline 87 & 1 & 0 & 3.171077 & -5.388593 & -2.039944 \\
\hline 88 & 1 & 0 & 4.858289 & -5.057319 & -3.854075 \\
\hline 89 & 1 & 0 & 5.741103 & -2.743019 & -4.280084 \\
\hline 90 & 1 & 0 & 4.883891 & -0.865846 & -2.866510 \\
\hline 91 & 1 & 0 & 4.217928 & -3.250945 & 0.653499 \\
\hline 92 & 1 & 0 & 3.485412 & -3.167134 & 2.239637 \\
\hline 93 & 1 & 0 & 5.392337 & -2.037799 & 3.274909 \\
\hline 94 & 1 & 0 & 6.831678 & -0.001977 & 3.433045 \\
\hline 95 & 1 & 0 & 6.581100 & 1.792276 & 1.685118 \\
\hline 96 & 1 & 0 & 4.861144 & 1.479788 & -0.093307 \\
\hline 97 & 8 & 0 & 1.155681 & -0.886451 & -1.854526 \\
\hline 98 & 6 & 0 & 0.519543 & -0.164225 & -2.711277 \\
\hline 99 & 8 & 0 & 0.937792 & 1.108401 & -2.923456 \\
\hline 100 & 8 & 0 & -0.465996 & -0.572675 & -3.343201 \\
\hline 101 & 8 & 0 & -1.544561 & -2.250035 & -1.667406 \\
\hline 102 & 1 & 0 & -2.272671 & -2.716939 & -2.095929 \\
\hline 103 & 1 & 0 & -1.077256 & -1.738976 & -2.400105 \\
\hline 104 & 1 & 0 & 2.806449 & 1.946855 & -0.122814 \\
\hline 105 & 1 & 0 & 1.568035 & 1.327380 & -2.208312 \\
\hline
\end{tabular}

\section{$3 \mathrm{Cu}_{3}$ (II,III,III)-OH-OH charge: +4}

\begin{tabular}{|c|c|c|c|c|c|}
\hline \multirow{2}{*}{$\begin{array}{l}\text { Center } \\
\text { Number }\end{array}$} & \multirow{2}{*}{$\begin{array}{l}\text { Atomic } \\
\text { Number }\end{array}$} & \multirow{2}{*}{$\begin{array}{l}\text { Atomic } \\
\text { Type }\end{array}$} & \multicolumn{3}{|c|}{ Coordinates (Angstroms) } \\
\hline & & & $\mathrm{X}$ & $\mathrm{Y}$ & $\mathrm{Z}$ \\
\hline 1 & 29 & 0 & -1.977854 & -0.583682 & -0.466455 \\
\hline 2 & 29 & 0 & 0.392668 & 1.994523 & 0.971190 \\
\hline 3 & 29 & 0 & 2.786274 & -0.345392 & -0.282602 \\
\hline 4 & 8 & 0 & -0.968452 & 0.956549 & -0.747134 \\
\hline 5 & 8 & 0 & -0.426368 & -1.318951 & 0.179299 \\
\hline 6 & 8 & 0 & 1.945574 & 0.743766 & 1.006661 \\
\hline 7 & 7 & 0 & -3.591906 & 0.104499 & -1.313679 \\
\hline 8 & 7 & 0 & -3.087045 & -2.102025 & 0.022786 \\
\hline 9 & 7 & 0 & -1.195135 & 3.352679 & 1.009576 \\
\hline 10 & 7 & 0 & 1.258158 & 3.412587 & -0.159944 \\
\hline
\end{tabular}




\begin{tabular}{|c|c|c|c|c|c|}
\hline 11 & 7 & 0 & -0.634817 & 1.152212 & 2.479116 \\
\hline 12 & 7 & 0 & 2.262362 & -2.651450 & -0.050884 \\
\hline 13 & 7 & 0 & 3.782649 & -1.115828 & -1.752562 \\
\hline 14 & 7 & 0 & 4.175420 & -0.856570 & 0.969389 \\
\hline 15 & 6 & 0 & -3.729227 & 1.184809 & -2.087076 \\
\hline 16 & 6 & 0 & -4.991692 & 1.496185 & -2.643607 \\
\hline 17 & 6 & 0 & -6.084426 & 0.678986 & -2.419164 \\
\hline 18 & 6 & 0 & -5.935526 & -0.495643 & -1.641020 \\
\hline 19 & 6 & 0 & -6.978123 & -1.441870 & -1.360790 \\
\hline 20 & 6 & 0 & -6.726928 & -2.567580 & -0.623301 \\
\hline 21 & 6 & 0 & -5.412403 & -2.840728 & -0.114460 \\
\hline 22 & 6 & 0 & -5.046207 & -3.994568 & 0.621637 \\
\hline 23 & 6 & 0 & -3.736880 & -4.157687 & 1.030734 \\
\hline 24 & 6 & 0 & -2.751053 & -3.189526 & 0.722394 \\
\hline 25 & 6 & 0 & -4.649933 & -0.740696 & -1.117945 \\
\hline 26 & 6 & 0 & -4.384376 & -1.913913 & -0.377866 \\
\hline 27 & 6 & 0 & -2.503310 & 2.000130 & -2.387476 \\
\hline 28 & 6 & 0 & -1.554776 & 2.166198 & -1.195320 \\
\hline 29 & 6 & 0 & -2.200733 & 2.895241 & -0.004750 \\
\hline 30 & 6 & 0 & -0.622866 & 4.695752 & 0.687985 \\
\hline 31 & 6 & 0 & 0.584744 & 4.586250 & -0.211131 \\
\hline 32 & 6 & 0 & 1.029379 & 5.652101 & -0.986728 \\
\hline 33 & 6 & 0 & 2.209612 & 5.509602 & -1.719263 \\
\hline 34 & 6 & 0 & 2.900957 & 4.297554 & -1.661195 \\
\hline 35 & 6 & 0 & 2.390497 & 3.271571 & -0.876448 \\
\hline 36 & 6 & 0 & -1.761360 & 3.298840 & 2.389624 \\
\hline 37 & 6 & 0 & -1.651879 & 1.904148 & 2.959045 \\
\hline 38 & 6 & 0 & -2.478389 & 1.443586 & 3.981226 \\
\hline 39 & 6 & 0 & -2.224459 & 0.190498 & 4.542407 \\
\hline 40 & 6 & 0 & -1.166040 & -0.576244 & 4.045584 \\
\hline 41 & 6 & 0 & -0.402638 & -0.065604 & 3.002944 \\
\hline 42 & 6 & 0 & -1.331351 & -3.351116 & 1.185339 \\
\hline 43 & 6 & 0 & -0.316257 & -2.718424 & 0.218974 \\
\hline 44 & 6 & 0 & 1.095062 & -3.112417 & 0.725010 \\
\hline 45 & 6 & 0 & 2.183160 & -2.941383 & -1.497525 \\
\hline 46 & 6 & 0 & 3.347229 & -2.301642 & -2.221569 \\
\hline 47 & 6 & 0 & 3.958939 & -2.867851 & -3.337844 \\
\hline 48 & 6 & 0 & 4.999389 & -2.186381 & -3.972534 \\
\hline 49 & 6 & 0 & 5.422016 & -0.954016 & -3.467512 \\
\hline 50 & 6 & 0 & 4.784629 & -0.441537 & -2.344029 \\
\hline 51 & 6 & 0 & 3.505703 & -3.198170 & 0.557745 \\
\hline 52 & 6 & 0 & 4.352287 & -2.161719 & 1.268227 \\
\hline 53 & 6 & 0 & 5.355776 & -2.540952 & 2.162459 \\
\hline 54 & 6 & 0 & 6.187697 & -1.573650 & 2.723430 \\
\hline
\end{tabular}




\begin{tabular}{|c|c|c|c|c|c|}
\hline 55 & 6 & 0 & 5.994657 & -0.228234 & 2.389920 \\
\hline 56 & 6 & 0 & 4.972342 & 0.094631 & 1.511088 \\
\hline 57 & 1 & 0 & -5.083948 & 2.381659 & -3.263133 \\
\hline 58 & 1 & 0 & -7.050883 & 0.926463 & -2.849581 \\
\hline 59 & 1 & 0 & -7.973270 & -1.251807 & -1.750639 \\
\hline 60 & 1 & 0 & -7.520290 & -3.281325 & -0.424315 \\
\hline 61 & 1 & 0 & -5.791581 & -4.749904 & 0.854754 \\
\hline 62 & 1 & 0 & -3.441472 & -5.038134 & 1.591109 \\
\hline 63 & 1 & 0 & -2.794050 & 2.981953 & -2.770473 \\
\hline 64 & 1 & 0 & -1.947997 & 1.499111 & -3.190904 \\
\hline 65 & 1 & 0 & -0.715712 & 2.759642 & -1.580169 \\
\hline 66 & 1 & 0 & -2.797115 & 3.754216 & -0.333677 \\
\hline 67 & 1 & 0 & -2.871691 & 2.189006 & 0.491559 \\
\hline 68 & 1 & 0 & -0.300734 & 5.160161 & 1.625199 \\
\hline 69 & 1 & 0 & -1.383980 & 5.353465 & 0.254490 \\
\hline 70 & 1 & 0 & 0.468560 & 6.581135 & -1.008857 \\
\hline 71 & 1 & 0 & 2.579725 & 6.329925 & -2.326384 \\
\hline 72 & 1 & 0 & 3.817297 & 4.148600 & -2.221057 \\
\hline 73 & 1 & 0 & 2.857882 & 2.300623 & -0.815254 \\
\hline 74 & 1 & 0 & -2.794290 & 3.663827 & 2.410236 \\
\hline 75 & 1 & 0 & -1.174068 & 3.966885 & 3.027221 \\
\hline 76 & 1 & 0 & -3.288225 & 2.065657 & 4.348952 \\
\hline 77 & 1 & 0 & -2.837909 & -0.177015 & 5.359349 \\
\hline 78 & 1 & 0 & -0.930643 & -1.546369 & 4.469936 \\
\hline 79 & 1 & 0 & 0.404028 & -0.618247 & 2.541019 \\
\hline 80 & 1 & 0 & -1.128032 & -4.415986 & 1.327374 \\
\hline 81 & 1 & 0 & -1.233121 & -2.866908 & 2.165991 \\
\hline 82 & 1 & 0 & -0.465188 & -3.152201 & -0.781524 \\
\hline 83 & 1 & 0 & 1.216692 & -2.733555 & 1.745019 \\
\hline 84 & 1 & 0 & 1.092186 & -4.212495 & 0.777595 \\
\hline 85 & 1 & 0 & 1.270361 & -2.477588 & -1.882294 \\
\hline 86 & 1 & 0 & 2.154942 & -4.017465 & -1.717410 \\
\hline 87 & 1 & 0 & 3.618712 & -3.831767 & -3.702480 \\
\hline 88 & 1 & 0 & 5.480388 & -2.615571 & -4.846154 \\
\hline 89 & 1 & 0 & 6.234870 & -0.400195 & -3.924465 \\
\hline 90 & 1 & 0 & 5.072966 & 0.503818 & -1.898624 \\
\hline 91 & 1 & 0 & 4.128837 & -3.648297 & -0.223454 \\
\hline 92 & 1 & 0 & 3.281762 & -4.012582 & 1.255399 \\
\hline 93 & 1 & 0 & 5.486705 & -3.591457 & 2.403449 \\
\hline 94 & 1 & 0 & 6.976557 & -1.862408 & 3.411374 \\
\hline 95 & 1 & 0 & 6.620134 & 0.555272 & 2.803593 \\
\hline 96 & 1 & 0 & 4.760562 & 1.119868 & 1.226021 \\
\hline 97 & 8 & 0 & 1.639948 & 0.201016 & -1.556609 \\
\hline 98 & 1 & 0 & 0.757180 & 0.246547 & -1.135908 \\
\hline
\end{tabular}


$3^{\prime} \quad \mathrm{Cu}_{3}(\mathrm{II}, \mathrm{III}, \mathrm{III})-\mathrm{OH}-\mathrm{OH}_{2}-\mathrm{CO}_{3} \quad$ charge: +3

\begin{tabular}{|c|c|c|c|c|c|}
\hline \multirow{2}{*}{$\begin{array}{l}\text { Center } \\
\text { Number }\end{array}$} & \multirow{2}{*}{$\begin{array}{l}\text { Atomic } \\
\text { Number }\end{array}$} & \multirow{2}{*}{$\begin{array}{l}\text { Atomic } \\
\text { Type }\end{array}$} & \multicolumn{3}{|c|}{ Coordinates (Angstroms) } \\
\hline & & & $\mathrm{X}$ & $\mathrm{Y}$ & $\mathrm{Z}$ \\
\hline 1 & 29 & 0 & -1.978559 & -0.614696 & -0.133018 \\
\hline 2 & 29 & 0 & 0.517449 & 2.016337 & 0.203537 \\
\hline 3 & 29 & 0 & 2.596539 & -0.630513 & -0.748684 \\
\hline 4 & 8 & 0 & -1.036152 & 0.818703 & -0.871384 \\
\hline 5 & 8 & 0 & -0.446169 & -0.955326 & 0.807195 \\
\hline 6 & 8 & 0 & 2.078930 & 1.263553 & -0.618749 \\
\hline 7 & 7 & 0 & -3.685191 & -0.143286 & -0.968637 \\
\hline 8 & 7 & 0 & -3.066102 & -1.836353 & 0.966690 \\
\hline 9 & 7 & 0 & -1.268169 & 2.937066 & 0.791004 \\
\hline 10 & 7 & 0 & 0.781953 & 3.907511 & -0.649479 \\
\hline 11 & 7 & 0 & 0.633016 & 1.586013 & 2.215798 \\
\hline 12 & 7 & 0 & 2.231882 & -2.482800 & 0.677528 \\
\hline 13 & 7 & 0 & 3.600439 & -2.185390 & -1.674106 \\
\hline 14 & 7 & 0 & 4.018887 & -0.319802 & 0.652827 \\
\hline 15 & 6 & 0 & -3.909303 & 0.712987 & -1.966145 \\
\hline 16 & 6 & 0 & -5.212393 & 0.837846 & -2.508162 \\
\hline 17 & 6 & 0 & -6.255511 & 0.078157 & -2.019375 \\
\hline 18 & 6 & 0 & -6.024332 & -0.834750 & -0.960690 \\
\hline 19 & 6 & 0 & -7.026665 & -1.666950 & -0.358725 \\
\hline 20 & 6 & 0 & -6.713695 & -2.516293 & 0.667120 \\
\hline 21 & 6 & 0 & -5.371986 & -2.606523 & 1.167923 \\
\hline 22 & 6 & 0 & -4.951943 & -3.459526 & 2.218027 \\
\hline 23 & 6 & 0 & -3.627092 & -3.467969 & 2.603304 \\
\hline 24 & 6 & 0 & -2.676808 & -2.638775 & 1.956733 \\
\hline 25 & 6 & 0 & -4.703986 & -0.909754 & -0.473785 \\
\hline 26 & 6 & 0 & -4.375932 & -1.802160 & 0.578532 \\
\hline 27 & 6 & 0 & -2.754389 & 1.508538 & -2.500374 \\
\hline 28 & 6 & 0 & -1.724870 & 1.908839 & -1.440174 \\
\hline 29 & 6 & 0 & -2.269844 & 2.824341 & -0.323288 \\
\hline 30 & 6 & 0 & -0.869867 & 4.346643 & 1.053782 \\
\hline 31 & 6 & 0 & -0.005588 & 4.847013 & -0.081191 \\
\hline 32 & 6 & 0 & 0.023263 & 6.174943 & -0.492989 \\
\hline 33 & 6 & 0 & 0.901601 & 6.542183 & -1.516106 \\
\hline 34 & 6 & 0 & 1.717289 & 5.569403 & -2.095419 \\
\hline 35 & 6 & 0 & 1.627583 & 4.259592 & -1.632982 \\
\hline
\end{tabular}




\begin{tabular}{|c|c|c|c|c|c|}
\hline 36 & 6 & 0 & -1.696303 & 2.236971 & 2.028097 \\
\hline 37 & 6 & 0 & -0.512910 & 1.828670 & 2.880572 \\
\hline 38 & 6 & 0 & -0.609690 & 1.650153 & 4.259131 \\
\hline 39 & 6 & 0 & 0.509688 & 1.196150 & 4.959978 \\
\hline 40 & 6 & 0 & 1.693573 & 0.946203 & 4.262452 \\
\hline 41 & 6 & 0 & 1.715108 & 1.162860 & 2.888276 \\
\hline 42 & 6 & 0 & -1.230011 & -2.641936 & 2.370668 \\
\hline 43 & 6 & 0 & -0.281246 & -2.285153 & 1.214732 \\
\hline 44 & 6 & 0 & 1.172829 & -2.475567 & 1.702964 \\
\hline 45 & 6 & 0 & 2.053737 & -3.526973 & -0.355957 \\
\hline 46 & 6 & 0 & 3.133099 & -3.422583 & -1.415372 \\
\hline 47 & 6 & 0 & 3.612450 & -4.533721 & -2.104573 \\
\hline 48 & 6 & 0 & 4.580707 & -4.353454 & -3.094165 \\
\hline 49 & 6 & 0 & 5.055614 & -3.067759 & -3.356970 \\
\hline 50 & 6 & 0 & 4.538955 & -2.007408 & -2.619524 \\
\hline 51 & 6 & 0 & 3.545911 & -2.610396 & 1.359470 \\
\hline 52 & 6 & 0 & 4.240849 & -1.283017 & 1.568306 \\
\hline 53 & 6 & 0 & 5.140269 & -1.082830 & 2.616354 \\
\hline 54 & 6 & 0 & 5.841680 & 0.120518 & 2.694726 \\
\hline 55 & 6 & 0 & 5.615288 & 1.103987 & 1.728507 \\
\hline 56 & 6 & 0 & 4.686203 & 0.848972 & 0.726516 \\
\hline 57 & 1 & 0 & -5.372168 & 1.540401 & -3.318605 \\
\hline 58 & 1 & 0 & -7.252085 & 0.178256 & -2.439550 \\
\hline 59 & 1 & 0 & -8.044049 & -1.608120 & -0.732142 \\
\hline 60 & 1 & 0 & -7.479512 & -3.140776 & 1.116039 \\
\hline 61 & 1 & 0 & -5.672276 & -4.105539 & 2.711402 \\
\hline 62 & 1 & 0 & -3.290059 & -4.116465 & 3.404624 \\
\hline 63 & 1 & 0 & -3.127625 & 2.397424 & -3.017414 \\
\hline 64 & 1 & 0 & -2.221805 & 0.900255 & -3.242941 \\
\hline 65 & 1 & 0 & -0.951221 & 2.458501 & -1.996439 \\
\hline 66 & 1 & 0 & -2.484035 & 3.817770 & -0.725038 \\
\hline 67 & 1 & 0 & -3.205561 & 2.426157 & 0.080866 \\
\hline 68 & 1 & 0 & -0.284796 & 4.356931 & 1.980270 \\
\hline 69 & 1 & 0 & -1.747303 & 4.985432 & 1.208446 \\
\hline 70 & 1 & 0 & -0.623964 & 6.907819 & -0.022359 \\
\hline 71 & 1 & 0 & 0.944521 & 7.571929 & -1.856347 \\
\hline 72 & 1 & 0 & 2.408973 & 5.815173 & -2.893323 \\
\hline 73 & 1 & 0 & 2.237242 & 3.465406 & -2.046965 \\
\hline 74 & 1 & 0 & -2.211907 & 1.322401 & 1.721703 \\
\hline 75 & 1 & 0 & -2.409851 & 2.842486 & 2.600739 \\
\hline 76 & 1 & 0 & -1.537981 & 1.872387 & 4.775639 \\
\hline 77 & 1 & 0 & 0.461940 & 1.056144 & 6.035326 \\
\hline 78 & 1 & 0 & 2.589305 & 0.609507 & 4.772230 \\
\hline 79 & 1 & 0 & 2.605043 & 1.006962 & 2.292869 \\
\hline
\end{tabular}




\begin{tabular}{|c|c|c|c|c|c|}
\hline 80 & 1 & 0 & -0.994082 & -3.625465 & 2.787536 \\
\hline 81 & 1 & 0 & -1.094596 & -1.908013 & 3.177596 \\
\hline 82 & 1 & 0 & -0.471395 & -2.966203 & 0.375026 \\
\hline 83 & 1 & 0 & 1.400732 & -1.668348 & 2.406350 \\
\hline 84 & 1 & 0 & 1.197824 & -3.425111 & 2.262422 \\
\hline 85 & 1 & 0 & 1.091210 & -3.351912 & -0.845122 \\
\hline 86 & 1 & 0 & 2.046033 & -4.539901 & 0.073010 \\
\hline 87 & 1 & 0 & 3.234959 & -5.523296 & -1.868531 \\
\hline 88 & 1 & 0 & 4.964637 & -5.205864 & -3.645420 \\
\hline 89 & 1 & 0 & 5.812159 & -2.886537 & -4.112030 \\
\hline 90 & 1 & 0 & 4.872891 & -0.987190 & -2.779310 \\
\hline 91 & 1 & 0 & 4.207610 & -3.223084 & 0.740143 \\
\hline 92 & 1 & 0 & 3.453180 & -3.138924 & 2.316419 \\
\hline 93 & 1 & 0 & 5.298025 & -1.867915 & 3.349008 \\
\hline 94 & 1 & 0 & 6.554885 & 0.287693 & 3.495837 \\
\hline 95 & 1 & 0 & 6.143551 & 2.050541 & 1.750070 \\
\hline 96 & 1 & 0 & 4.425066 & 1.581046 & -0.028011 \\
\hline 97 & 8 & 0 & 1.170495 & -1.029254 & -2.061065 \\
\hline 98 & 6 & 0 & 0.599819 & -0.229329 & -2.876404 \\
\hline 99 & 8 & 0 & 0.965739 & 0.965251 & -3.101084 \\
\hline 100 & 8 & 0 & -0.425991 & -0.633930 & -3.521546 \\
\hline 101 & 8 & 0 & -1.640037 & -2.325997 & -1.651600 \\
\hline 102 & 1 & 0 & -2.376868 & -2.779607 & -2.080827 \\
\hline 103 & 1 & 0 & -1.133066 & -1.903571 & -2.375362 \\
\hline 104 & 1 & 0 & 1.840553 & 1.400956 & -1.559360 \\
\hline
\end{tabular}

$4 \mathrm{Cu}_{3}(\mathrm{III}, \mathrm{III}, \mathrm{III})-0-0 \mathrm{H}$ charge: +4

\begin{tabular}{rrrrrr} 
Center & Atomic & Atomic & \multicolumn{3}{c}{ Coordinates (Angstroms) } \\
Number & Number & Type & X & Y & Z \\
- \hdashline-----1.984560 & -0.568493 & -0.462968 \\
1 & 29 & 0 & -1.9845 \\
2 & 29 & 0 & 0.475948 & 2.005610 & 0.945154 \\
3 & 29 & 0 & 2.796938 & -0.331323 & -0.391150 \\
4 & 8 & 0 & -0.986328 & 0.973314 & -0.755273 \\
5 & 8 & 0 & -0.399323 & -1.315147 & 0.088667 \\
6 & 8 & 0 & 2.111284 & 0.983632 & 0.658187 \\
7 & 7 & 0 & -3.632938 & 0.135553 & -1.236081 \\
8 & 7 & 0 & -3.077592 & -2.096418 & 0.035173 \\
9 & 7 & 0 & -1.203923 & 3.218072 & 1.204743 \\
10 & 7 & 0 & 1.128636 & 3.562755 & -0.150114 \\
11 & 7 & 0 & -0.280425 & 1.003303 & 2.478399
\end{tabular}




\begin{tabular}{|c|c|c|c|c|c|}
\hline 12 & 7 & 0 & 2.255293 & -2.645864 & -0.211893 \\
\hline 13 & 7 & 0 & 3.762252 & -1.124800 & -1.888717 \\
\hline 14 & 7 & 0 & 4.089521 & -0.868085 & 0.937164 \\
\hline 15 & 6 & 0 & -3.804398 & 1.241791 & -1.964908 \\
\hline 16 & 6 & 0 & -5.082270 & 1.551389 & -2.486551 \\
\hline 17 & 6 & 0 & -6.157455 & 0.709381 & -2.271231 \\
\hline 18 & 6 & 0 & -5.975914 & -0.486606 & -1.533700 \\
\hline 19 & 6 & 0 & -7.001243 & -1.452520 & -1.256984 \\
\hline 20 & 6 & 0 & -6.723098 & -2.591257 & -0.549797 \\
\hline 21 & 6 & 0 & -5.396332 & -2.858733 & -0.070905 \\
\hline 22 & 6 & 0 & -5.004579 & -4.018618 & 0.642051 \\
\hline 23 & 6 & 0 & -3.687146 & -4.171026 & 1.029616 \\
\hline 24 & 6 & 0 & -2.718538 & -3.187450 & 0.717382 \\
\hline 25 & 6 & 0 & -4.676344 & -0.729774 & -1.045403 \\
\hline 26 & 6 & 0 & -4.383511 & -1.916098 & -0.338219 \\
\hline 27 & 6 & 0 & -2.603628 & 2.098258 & -2.252178 \\
\hline 28 & 6 & 0 & -1.613131 & 2.199638 & -1.087682 \\
\hline 29 & 6 & 0 & -2.226727 & 2.826775 & 0.177191 \\
\hline 30 & 6 & 0 & -0.712717 & 4.620324 & 1.023596 \\
\hline 31 & 6 & 0 & 0.391130 & 4.689558 & -0.004090 \\
\hline 32 & 6 & 0 & 0.689997 & 5.852952 & -0.704242 \\
\hline 33 & 6 & 0 & 1.788626 & 5.858456 & -1.567894 \\
\hline 34 & 6 & 0 & 2.543117 & 4.692779 & -1.715170 \\
\hline 35 & 6 & 0 & 2.179129 & 3.560895 & -0.995168 \\
\hline 36 & 6 & 0 & -1.704378 & 2.970214 & 2.590741 \\
\hline 37 & 6 & 0 & -1.360049 & 1.574023 & 3.059166 \\
\hline 38 & 6 & 0 & -2.026401 & 0.952376 & 4.113123 \\
\hline 39 & 6 & 0 & -1.535213 & -0.260415 & 4.600860 \\
\hline 40 & 6 & 0 & -0.401722 & -0.827212 & 4.008890 \\
\hline 41 & 6 & 0 & 0.190064 & -0.170890 & 2.937189 \\
\hline 42 & 6 & 0 & -1.288724 & -3.330042 & 1.151224 \\
\hline 43 & 6 & 0 & -0.305643 & -2.716962 & 0.140002 \\
\hline 44 & 6 & 0 & 1.116705 & -3.124081 & 0.593888 \\
\hline 45 & 6 & 0 & 2.143950 & -2.933182 & -1.656749 \\
\hline 46 & 6 & 0 & 3.293839 & -2.283274 & -2.395393 \\
\hline 47 & 6 & 0 & 3.870510 & -2.821835 & -3.542941 \\
\hline 48 & 6 & 0 & 4.917005 & -2.141521 & -4.169903 \\
\hline 49 & 6 & 0 & 5.378607 & -0.940003 & -3.626416 \\
\hline 50 & 6 & 0 & 4.771157 & -0.453718 & -2.474745 \\
\hline 51 & 6 & 0 & 3.517011 & -3.188973 & 0.363167 \\
\hline 52 & 6 & 0 & 4.269003 & -2.179832 & 1.202230 \\
\hline 53 & 6 & 0 & 5.190494 & -2.570717 & 2.173857 \\
\hline 54 & 6 & 0 & 5.934934 & -1.604026 & 2.850542 \\
\hline 55 & 6 & 0 & 5.729637 & -0.252449 & 2.557388 \\
\hline
\end{tabular}




\begin{tabular}{|c|c|c|c|c|c|}
\hline 56 & 6 & 0 & 4.785974 & 0.083665 & 1.596664 \\
\hline 57 & 1 & 0 & -5.200447 & 2.457877 & -3.070305 \\
\hline 58 & 1 & 0 & -7.135810 & 0.956043 & -2.674400 \\
\hline 59 & 1 & 0 & -8.006148 & -1.264890 & -1.622231 \\
\hline 60 & 1 & 0 & -7.504534 & -3.317964 & -0.350506 \\
\hline 61 & 1 & 0 & -5.737309 & -4.785788 & 0.876673 \\
\hline 62 & 1 & 0 & -3.372881 & -5.053842 & 1.575746 \\
\hline 63 & 1 & 0 & -2.925419 & 3.098143 & -2.555778 \\
\hline 64 & 1 & 0 & -2.071160 & 1.665003 & -3.108786 \\
\hline 65 & 1 & 0 & -0.802038 & 2.837444 & -1.459468 \\
\hline 66 & 1 & 0 & -2.839916 & 3.701133 & -0.069539 \\
\hline 67 & 1 & 0 & -2.880017 & 2.077348 & 0.631827 \\
\hline 68 & 1 & 0 & -0.300341 & 4.956536 & 1.980069 \\
\hline 69 & 1 & 0 & -1.537127 & 5.297092 & 0.773799 \\
\hline 70 & 1 & 0 & 0.082144 & 6.742057 & -0.569814 \\
\hline 71 & 1 & 0 & 2.046327 & 6.757564 & -2.119070 \\
\hline 72 & 1 & 0 & 3.397426 & 4.658492 & -2.381876 \\
\hline 73 & 1 & 0 & 2.698054 & 2.617545 & -1.089874 \\
\hline 74 & 1 & 0 & -2.778551 & 3.169195 & 2.667066 \\
\hline 75 & 1 & 0 & -1.207373 & 3.671975 & 3.267561 \\
\hline 76 & 1 & 0 & -2.891299 & 1.426182 & 4.566551 \\
\hline 77 & 1 & 0 & -2.020194 & -0.746573 & 5.441897 \\
\hline 78 & 1 & 0 & 0.022366 & -1.752289 & 4.384310 \\
\hline 79 & 1 & 0 & 1.057909 & -0.555229 & 2.416929 \\
\hline 80 & 1 & 0 & -1.073984 & -4.389355 & 1.315215 \\
\hline 81 & 1 & 0 & -1.164284 & -2.816556 & 2.113844 \\
\hline 82 & 1 & 0 & -0.499128 & -3.157253 & -0.850083 \\
\hline 83 & 1 & 0 & 1.273986 & -2.764888 & 1.615616 \\
\hline 84 & 1 & 0 & 1.116318 & -4.224959 & 0.625151 \\
\hline 85 & 1 & 0 & 1.213297 & -2.485317 & -2.019134 \\
\hline 86 & 1 & 0 & 2.118488 & -4.008869 & -1.879416 \\
\hline 87 & 1 & 0 & 3.503392 & -3.764792 & -3.935340 \\
\hline 88 & 1 & 0 & 5.373335 & -2.549427 & -5.066712 \\
\hline 89 & 1 & 0 & 6.197967 & -0.389594 & -4.075889 \\
\hline 90 & 1 & 0 & 5.088408 & 0.469445 & -2.002327 \\
\hline 91 & 1 & 0 & 4.181176 & -3.499860 & -0.449890 \\
\hline 92 & 1 & 0 & 3.332759 & -4.091948 & 0.956042 \\
\hline 93 & 1 & 0 & 5.329395 & -3.626777 & 2.383757 \\
\hline 94 & 1 & 0 & 6.663042 & -1.900353 & 3.599585 \\
\hline 95 & 1 & 0 & 6.282637 & 0.530016 & 3.065420 \\
\hline 96 & 1 & 0 & 4.552584 & 1.111545 & 1.343705 \\
\hline 97 & 8 & 0 & 1.668105 & 0.435338 & -1.583517 \\
\hline 98 & 1 & 0 & 0.749400 & 0.341587 & -1.246581 \\
\hline
\end{tabular}


4' $\mathrm{Cu}_{3}(\mathrm{III}, \mathrm{III}, \mathrm{III})-\mathrm{O}-\mathrm{OH}_{2}-\mathrm{CO}_{3} \quad$ charge: +3

\begin{tabular}{|c|c|c|c|c|c|}
\hline \multirow{2}{*}{$\begin{array}{l}\text { Center } \\
\text { Number }\end{array}$} & \multirow{2}{*}{$\begin{array}{l}\text { Atomic } \\
\text { Number }\end{array}$} & \multirow{2}{*}{$\begin{array}{l}\text { Atomic } \\
\text { Type }\end{array}$} & \multicolumn{3}{|c|}{ Coordinates (Angstroms) } \\
\hline & & & $X$ & $\mathrm{Y}$ & Z \\
\hline 1 & 29 & 0 & -2.016603 & -0.608476 & -0.143398 \\
\hline 2 & 29 & 0 & 0.476135 & 1.953938 & 0.225669 \\
\hline 3 & 29 & 0 & 2.664880 & -0.612699 & -0.743745 \\
\hline 4 & 8 & 0 & -1.082395 & 0.845755 & -0.844483 \\
\hline 5 & 8 & 0 & -0.483564 & -0.964733 & 0.793873 \\
\hline 6 & 8 & 0 & 2.068386 & 1.166684 & -0.373271 \\
\hline 7 & 7 & 0 & -3.723063 & -0.120836 & -0.967761 \\
\hline 8 & 7 & 0 & -3.091199 & -1.877530 & 0.904045 \\
\hline 9 & 7 & 0 & -1.280501 & 2.986950 & 0.776230 \\
\hline 10 & 7 & 0 & 0.841134 & 3.778198 & -0.664053 \\
\hline 11 & 7 & 0 & 0.548912 & 1.581629 & 2.254089 \\
\hline 12 & 7 & 0 & 2.237277 & -2.496067 & 0.634261 \\
\hline 13 & 7 & 0 & 3.632471 & -2.138606 & -1.704462 \\
\hline 14 & 7 & 0 & 4.085340 & -0.368851 & 0.685930 \\
\hline 15 & 6 & 0 & -3.948163 & 0.755535 & -1.947510 \\
\hline 16 & 6 & 0 & -5.256409 & 0.905201 & -2.470684 \\
\hline 17 & 6 & 0 & -6.301465 & 0.145075 & -1.986335 \\
\hline 18 & 6 & 0 & -6.066233 & -0.797325 & -0.954801 \\
\hline 19 & 6 & 0 & -7.066869 & -1.641583 & -0.367088 \\
\hline 20 & 6 & 0 & -6.746870 & -2.525925 & 0.626543 \\
\hline 21 & 6 & 0 & -5.399653 & -2.641406 & 1.107029 \\
\hline 22 & 6 & 0 & -4.971533 & -3.534632 & 2.119780 \\
\hline 23 & 6 & 0 & -3.642079 & -3.564702 & 2.486865 \\
\hline 24 & 6 & 0 & -2.694664 & -2.716834 & 1.860084 \\
\hline 25 & 6 & 0 & -4.741560 & -0.893953 & -0.483862 \\
\hline 26 & 6 & 0 & -4.406310 & -1.822277 & 0.534236 \\
\hline 27 & 6 & 0 & -2.787501 & 1.538029 & -2.488054 \\
\hline 28 & 6 & 0 & -1.752542 & 1.938302 & -1.434256 \\
\hline 29 & 6 & 0 & -2.283483 & 2.879148 & -0.333960 \\
\hline 30 & 6 & 0 & -0.808026 & 4.382729 & 0.987606 \\
\hline 31 & 6 & 0 & 0.099590 & 4.785171 & -0.153709 \\
\hline 32 & 6 & 0 & 0.211550 & 6.085855 & -0.630996 \\
\hline 33 & 6 & 0 & 1.125783 & 6.346279 & -1.656690 \\
\hline 34 & 6 & 0 & 1.889759 & 5.299847 & -2.174898 \\
\hline 35 & 6 & 0 & 1.718122 & 4.020501 & -1.652117 \\
\hline 36 & 6 & 0 & -1.740061 & 2.344325 & 2.031902 \\
\hline 37 & 6 & 0 & -0.577619 & 1.924808 & 2.907276 \\
\hline
\end{tabular}




\begin{tabular}{|c|c|c|c|c|c|}
\hline 38 & 6 & 0 & -0.675588 & 1.826256 & 4.293907 \\
\hline 39 & 6 & 0 & 0.420033 & 1.345759 & 5.014153 \\
\hline 40 & 6 & 0 & 1.581497 & 0.984970 & 4.327123 \\
\hline 41 & 6 & 0 & 1.607089 & 1.125778 & 2.943466 \\
\hline 42 & 6 & 0 & -1.245975 & -2.741417 & 2.265807 \\
\hline 43 & 6 & 0 & -0.294380 & -2.309573 & 1.137568 \\
\hline 44 & 6 & 0 & 1.157831 & -2.501448 & 1.639391 \\
\hline 45 & 6 & 0 & 2.063828 & -3.504318 & -0.434307 \\
\hline 46 & 6 & 0 & 3.158545 & -3.379904 & -1.475332 \\
\hline 47 & 6 & 0 & 3.645089 & -4.476832 & -2.181951 \\
\hline 48 & 6 & 0 & 4.625599 & -4.278547 & -3.155936 \\
\hline 49 & 6 & 0 & 5.105612 & -2.988792 & -3.387584 \\
\hline 50 & 6 & 0 & 4.582473 & -1.942463 & -2.635274 \\
\hline 51 & 6 & 0 & 3.537527 & -2.659339 & 1.334777 \\
\hline 52 & 6 & 0 & 4.242107 & -1.346014 & 1.600187 \\
\hline 53 & 6 & 0 & 5.084183 & -1.168583 & 2.698892 \\
\hline 54 & 6 & 0 & 5.788841 & 0.028205 & 2.835015 \\
\hline 55 & 6 & 0 & 5.623826 & 1.029321 & 1.874615 \\
\hline 56 & 6 & 0 & 4.753610 & 0.794186 & 0.816300 \\
\hline 57 & 1 & 0 & -5.418429 & 1.625823 & -3.264626 \\
\hline 58 & 1 & 0 & -7.301862 & 0.264619 & -2.392095 \\
\hline 59 & 1 & 0 & -8.088156 & -1.565073 & -0.726369 \\
\hline 60 & 1 & 0 & -7.511000 & -3.160710 & 1.063717 \\
\hline 61 & 1 & 0 & -5.689432 & -4.194015 & 2.598791 \\
\hline 62 & 1 & 0 & -3.298827 & -4.243823 & 3.259676 \\
\hline 63 & 1 & 0 & -3.152648 & 2.427165 & -3.010184 \\
\hline 64 & 1 & 0 & -2.260255 & 0.921397 & -3.227517 \\
\hline 65 & 1 & 0 & -0.966621 & 2.463008 & -1.996080 \\
\hline 66 & 1 & 0 & -2.480767 & 3.869934 & -0.751179 \\
\hline 67 & 1 & 0 & -3.226492 & 2.502740 & 0.074326 \\
\hline 68 & 1 & 0 & -0.236060 & 4.399245 & 1.922172 \\
\hline 69 & 1 & 0 & -1.649888 & 5.075526 & 1.102257 \\
\hline 70 & 1 & 0 & -0.398272 & 6.878864 & -0.210619 \\
\hline 71 & 1 & 0 & 1.233742 & 7.353062 & -2.047605 \\
\hline 72 & 1 & 0 & 2.602154 & 5.465839 & -2.975159 \\
\hline 73 & 1 & 0 & 2.259849 & 3.155864 & -2.014797 \\
\hline 74 & 1 & 0 & -2.278881 & 1.434993 & 1.747202 \\
\hline 75 & 1 & 0 & -2.440215 & 2.988094 & 2.578826 \\
\hline 76 & 1 & 0 & -1.586915 & 2.127198 & 4.800518 \\
\hline 77 & 1 & 0 & 0.371169 & 1.266727 & 6.095620 \\
\hline 78 & 1 & 0 & 2.456940 & 0.619362 & 4.852095 \\
\hline 79 & 1 & 0 & 2.481208 & 0.878481 & 2.353331 \\
\hline 80 & 1 & 0 & -1.007236 & -3.749109 & 2.618785 \\
\hline 81 & 1 & 0 & -1.113372 & -2.061919 & 3.119562 \\
\hline
\end{tabular}




$\begin{array}{rrrrrr}82 & 1 & 0 & -0.463913 & -2.951055 & 0.262904 \\ 83 & 1 & 0 & 1.372366 & -1.703439 & 2.357399 \\ 84 & 1 & 0 & 1.177202 & -3.457719 & 2.187271 \\ 85 & 1 & 0 & 1.111496 & -3.301303 & -0.932656 \\ 86 & 1 & 0 & 2.037197 & -4.530980 & -0.040054 \\ 87 & 1 & 0 & 3.262809 & -5.470204 & -1.971156 \\ 88 & 1 & 0 & 5.014658 & -5.120506 & -3.719526 \\ 89 & 1 & 0 & 5.870917 & -2.793624 & -4.130204 \\ 90 & 1 & 0 & 4.919358 & -0.919801 & -2.770606 \\ 91 & 1 & 0 & 4.203857 & -3.257759 & 0.706276 \\ 92 & 1 & 0 & 3.423401 & -3.217649 & 2.272332 \\ 93 & 1 & 0 & 5.194421 & -1.964948 & 3.428015 \\ 94 & 1 & 0 & 6.457449 & 0.177020 & 3.677155 \\ 95 & 1 & 0 & 6.156190 & 1.971474 & 1.941150 \\ 96 & 1 & 0 & 4.555256 & 1.538558 & 0.053001 \\ 97 & 8 & 0 & 1.221812 & -0.908234 & -2.014907 \\ 98 & 6 & 0 & 0.665178 & -0.038914 & -2.773644 \\ 99 & 8 & 0 & 1.035036 & 1.177154 & -2.844835 \\ 100 & 8 & 0 & -0.315951 & -0.387027 & -3.498361 \\ 101 & 8 & 0 & -1.599601 & -2.192839 & -1.770292 \\ 102 & 1 & 0 & -2.304451 & -2.648673 & -2.247753 \\ 103 & 1 & 0 & -1.082396 & -1.714093 & -2.452370\end{array}$

TS1

\begin{tabular}{rrrrrr} 
Center & Atomic & Atomic & \multicolumn{3}{c}{ Coordinates (Angstroms) } \\
Number & Number & Type & X & Y & $\mathrm{Z}$ \\
-1 & 29 & 0 & -2.079611 & -0.561536 & -0.340088 \\
2 & 29 & 0 & 0.874660 & 2.124756 & 0.324524 \\
3 & 29 & 0 & 2.382792 & -0.952738 & -0.142019 \\
4 & 8 & 0 & -0.980248 & 0.896560 & -0.754280 \\
5 & 8 & 0 & -0.635715 & -1.351221 & 0.511399 \\
6 & 8 & 0 & 2.321208 & 0.913940 & 0.268811 \\
7 & 7 & 0 & -3.718030 & 0.274591 & -1.029991 \\
8 & 7 & 0 & -3.342295 & -1.881454 & 0.425769 \\
9 & 7 & 0 & -0.619484 & 3.594184 & 0.340308 \\
10 & 7 & 0 & 2.039968 & 3.717897 & -0.215128 \\
11 & 7 & 0 & 0.000422 & 1.625737 & 2.117069 \\
12 & 7 & 0 & 1.964761 & -3.036461 & 0.120188 \\
13 & 7 & 0 & 3.739615 & -1.985497 & -1.623436 \\
14 & 7 & 0 & 3.409008 & -1.260973 & 1.586778
\end{tabular}




\begin{tabular}{|c|c|c|c|c|c|}
\hline 15 & 6 & 0 & -3.816729 & 1.280317 & -1.898478 \\
\hline 16 & 6 & 0 & -5.089956 & 1.757589 & -2.291032 \\
\hline 17 & 6 & 0 & -6.240775 & 1.169258 & -1.805167 \\
\hline 18 & 6 & 0 & -6.144725 & 0.059725 & -0.930898 \\
\hline 19 & 6 & 0 & -7.260175 & -0.671032 & -0.401968 \\
\hline 20 & 6 & 0 & -7.067668 & -1.771965 & 0.386805 \\
\hline 21 & 6 & 0 & -5.746185 & -2.232533 & 0.703929 \\
\hline 22 & 6 & 0 & -5.452907 & -3.399261 & 1.451833 \\
\hline 23 & 6 & 0 & -4.139435 & -3.766363 & 1.645530 \\
\hline 24 & 6 & 0 & -3.077833 & -2.985723 & 1.118998 \\
\hline 25 & 6 & 0 & -4.842684 & -0.357056 & -0.584381 \\
\hline 26 & 6 & 0 & -4.642111 & -1.506639 & 0.216051 \\
\hline 27 & 6 & 0 & -2.541904 & 1.832035 & -2.450514 \\
\hline 28 & 6 & 0 & -1.474322 & 2.059411 & -1.374489 \\
\hline 29 & 6 & 0 & -1.868621 & 3.066553 & -0.285630 \\
\hline 30 & 6 & 0 & -0.118680 & 4.781835 & -0.410584 \\
\hline 31 & 6 & 0 & 1.386260 & 4.886745 & -0.360541 \\
\hline 32 & 6 & 0 & 2.066191 & 6.085745 & -0.552090 \\
\hline 33 & 6 & 0 & 3.460780 & 6.062279 & -0.618463 \\
\hline 34 & 6 & 0 & 4.129739 & 4.843719 & -0.487771 \\
\hline 35 & 6 & 0 & 3.382600 & 3.689541 & -0.278901 \\
\hline 36 & 6 & 0 & -0.782437 & 3.891659 & 1.789879 \\
\hline 37 & 6 & 0 & -0.784992 & 2.612196 & 2.598412 \\
\hline 38 & 6 & 0 & -1.495936 & 2.461148 & 3.785483 \\
\hline 39 & 6 & 0 & -1.367625 & 1.265487 & 4.497292 \\
\hline 40 & 6 & 0 & -0.547154 & 0.254798 & 3.992975 \\
\hline 41 & 6 & 0 & 0.117708 & 0.471816 & 2.789671 \\
\hline 42 & 6 & 0 & -1.656258 & -3.394481 & 1.365749 \\
\hline 43 & 6 & 0 & -0.620611 & -2.752341 & 0.425746 \\
\hline 44 & 6 & 0 & 0.742189 & -3.306744 & 0.909478 \\
\hline 45 & 6 & 0 & 1.956302 & -3.610023 & -1.247445 \\
\hline 46 & 6 & 0 & 3.176170 & -3.140979 & -2.026571 \\
\hline 47 & 6 & 0 & 3.666574 & -3.861521 & -3.112880 \\
\hline 48 & 6 & 0 & 4.761385 & -3.355957 & -3.816606 \\
\hline 49 & 6 & 0 & 5.339597 & -2.155725 & -3.402224 \\
\hline 50 & 6 & 0 & 4.797478 & -1.505675 & -2.296004 \\
\hline 51 & 6 & 0 & 3.124607 & -3.560844 & 0.899823 \\
\hline 52 & 6 & 0 & 3.603185 & -2.554404 & 1.914018 \\
\hline 53 & 6 & 0 & 4.275929 & -2.916527 & 3.079125 \\
\hline 54 & 6 & 0 & 4.774752 & -1.914810 & 3.912066 \\
\hline 55 & 6 & 0 & 4.580296 & -0.577153 & 3.559050 \\
\hline 56 & 6 & 0 & 3.889001 & -0.289880 & 2.388575 \\
\hline 57 & 1 & 0 & -5.142874 & 2.583460 & -2.991590 \\
\hline 58 & 1 & 0 & -7.216840 & 1.538679 & -2.106066 \\
\hline
\end{tabular}




\begin{tabular}{|c|c|c|c|c|c|}
\hline 59 & 1 & 0 & -8.263840 & -0.341978 & -0.651548 \\
\hline 60 & 1 & 0 & -7.917208 & -2.328817 & 0.769134 \\
\hline 61 & 1 & 0 & -6.260459 & -4.003748 & 1.854262 \\
\hline 62 & 1 & 0 & -3.893043 & -4.664237 & 2.201984 \\
\hline 63 & 1 & 0 & -2.731655 & 2.764501 & -2.987998 \\
\hline 64 & 1 & 0 & -2.120228 & 1.119354 & -3.168207 \\
\hline 65 & 1 & 0 & -0.616122 & 2.455403 & -1.941045 \\
\hline 66 & 1 & 0 & -2.475920 & 3.898897 & -0.662056 \\
\hline 67 & 1 & 0 & -2.446226 & 2.540544 & 0.478010 \\
\hline 68 & 1 & 0 & -0.604406 & 5.697656 & -0.053849 \\
\hline 69 & 1 & 0 & -0.405803 & 4.655587 & -1.459401 \\
\hline 70 & 1 & 0 & 1.517156 & 7.015881 & -0.656727 \\
\hline 71 & 1 & 0 & 4.015685 & 6.982410 & -0.771264 \\
\hline 72 & 1 & 0 & 5.211119 & 4.787350 & -0.540444 \\
\hline 73 & 1 & 0 & 3.832094 & 2.711285 & -0.156571 \\
\hline 74 & 1 & 0 & -1.687016 & 4.483964 & 1.971570 \\
\hline 75 & 1 & 0 & 0.076697 & 4.499045 & 2.096973 \\
\hline 76 & 1 & 0 & -2.125133 & 3.265353 & 4.152528 \\
\hline 77 & 1 & 0 & -1.900213 & 1.128701 & 5.433188 \\
\hline 78 & 1 & 0 & -0.421242 & -0.682793 & 4.523046 \\
\hline 79 & 1 & 0 & 0.746580 & -0.277982 & 2.326873 \\
\hline 80 & 1 & 0 & -1.605241 & -4.487072 & 1.311808 \\
\hline 81 & 1 & 0 & -1.411960 & -3.119726 & 2.401848 \\
\hline 82 & 1 & 0 & -0.801394 & -3.073683 & -0.608889 \\
\hline 83 & 1 & 0 & 0.924932 & -2.904516 & 1.911068 \\
\hline 84 & 1 & 0 & 0.623392 & -4.395920 & 1.007130 \\
\hline 85 & 1 & 0 & 1.058636 & -3.247291 & -1.752195 \\
\hline 86 & 1 & 0 & 1.920777 & -4.707488 & -1.212864 \\
\hline 87 & 1 & 0 & 3.203107 & -4.799276 & -3.402866 \\
\hline 88 & 1 & 0 & 5.160659 & -3.895751 & -4.669274 \\
\hline 89 & 1 & 0 & 6.195345 & -1.733846 & -3.917310 \\
\hline 90 & 1 & 0 & 5.214444 & -0.572725 & -1.928934 \\
\hline 91 & 1 & 0 & 3.946429 & -3.750761 & 0.205845 \\
\hline 92 & 1 & 0 & 2.878645 & -4.517470 & 1.376534 \\
\hline 93 & 1 & 0 & 4.415253 & -3.965293 & 3.320348 \\
\hline 94 & 1 & 0 & 5.309465 & -2.173904 & 4.820400 \\
\hline 95 & 1 & 0 & 4.959972 & 0.229686 & 4.175780 \\
\hline 96 & 1 & 0 & 3.707224 & 0.724307 & 2.052280 \\
\hline 97 & 8 & 0 & 1.225967 & -0.852891 & -1.729994 \\
\hline 98 & 6 & 0 & 0.996223 & 0.197435 & -2.400924 \\
\hline 99 & 8 & 0 & 1.496725 & 1.351198 & -2.155988 \\
\hline 100 & 8 & 0 & 0.202807 & 0.193384 & -3.398534 \\
\hline 101 & 8 & 0 & -1.713690 & -1.680259 & -2.341436 \\
\hline 102 & 1 & 0 & -2.361285 & -1.910251 & -3.019374 \\
\hline
\end{tabular}


TS1'

\begin{tabular}{|c|c|c|c|c|c|}
\hline \multirow{2}{*}{$\begin{array}{l}\text { Center } \\
\text { Number }\end{array}$} & \multirow{2}{*}{$\begin{array}{l}\text { Atomic } \\
\text { Number }\end{array}$} & \multirow{2}{*}{$\begin{array}{l}\text { Atomic } \\
\text { Type }\end{array}$} & \multicolumn{3}{|c|}{ Coordinates (Angstroms) } \\
\hline & & & $\mathrm{X}$ & $\mathrm{Y}$ & $\mathrm{Z}$ \\
\hline 1 & 29 & 0 & -1.970227 & -0.623466 & -0.446647 \\
\hline 2 & 29 & 0 & 0.476927 & 2.160599 & 0.894941 \\
\hline 3 & 29 & 0 & 2.832024 & -0.352818 & -0.429210 \\
\hline 4 & 8 & 0 & -1.011958 & 0.936572 & -0.775944 \\
\hline 5 & 8 & 0 & -0.358583 & -1.336385 & 0.075819 \\
\hline 6 & 8 & 0 & 2.044117 & 1.111730 & 0.400758 \\
\hline 7 & 7 & 0 & -3.645236 & 0.041882 & -1.203329 \\
\hline 8 & 7 & 0 & -3.027095 & -2.160206 & 0.091005 \\
\hline 9 & 7 & 0 & -1.268519 & 3.240652 & 1.181158 \\
\hline 10 & 7 & 0 & 1.030428 & 3.744391 & -0.177762 \\
\hline 11 & 7 & 0 & -0.168368 & 1.091707 & 2.421846 \\
\hline 12 & 7 & 0 & 2.312477 & -2.656052 & -0.223007 \\
\hline 13 & 7 & 0 & 3.764364 & -1.176742 & -1.987361 \\
\hline 14 & 7 & 0 & 4.082041 & -0.853980 & 0.974113 \\
\hline 15 & 6 & 0 & -3.851138 & 1.138518 & -1.938293 \\
\hline 16 & 6 & 0 & -5.140384 & 1.410681 & -2.452729 \\
\hline 17 & 6 & 0 & -6.192003 & 0.542971 & -2.223328 \\
\hline 18 & 6 & 0 & -5.974874 & -0.640929 & -1.476141 \\
\hline 19 & 6 & 0 & -6.974111 & -1.628176 & -1.180043 \\
\hline 20 & 6 & 0 & -6.663380 & -2.750117 & -0.459657 \\
\hline 21 & 6 & 0 & -5.327404 & -2.978321 & 0.014001 \\
\hline 22 & 6 & 0 & -4.903568 & -4.116091 & 0.744077 \\
\hline 23 & 6 & 0 & -3.580902 & -4.229488 & 1.127528 \\
\hline 24 & 6 & 0 & -2.638033 & -3.228801 & 0.791955 \\
\hline 25 & 6 & 0 & -4.665720 & -0.846830 & -0.996137 \\
\hline 26 & 6 & 0 & -4.339379 & -2.016163 & -0.275834 \\
\hline 27 & 6 & 0 & -2.677476 & 2.027847 & -2.240164 \\
\hline 28 & 6 & 0 & -1.672605 & 2.151726 & -1.089960 \\
\hline 29 & 6 & 0 & -2.287501 & 2.755940 & 0.187233 \\
\hline 30 & 6 & 0 & -0.895757 & 4.676092 & 0.966855 \\
\hline 31 & 6 & 0 & 0.206778 & 4.813729 & -0.056078 \\
\hline 32 & 6 & 0 & 0.430183 & 5.987027 & -0.766895 \\
\hline 33 & 6 & 0 & 1.542519 & 6.064541 & -1.610022 \\
\hline 34 & 6 & 0 & 2.389988 & 4.960362 & -1.724074 \\
\hline 35 & 6 & 0 & 2.099203 & 3.811778 & -0.997340 \\
\hline
\end{tabular}




\begin{tabular}{|c|c|c|c|c|c|}
\hline 36 & 6 & 0 & -1.704930 & 2.967939 & 2.585312 \\
\hline 37 & 6 & 0 & -1.263904 & 1.593057 & 3.037555 \\
\hline 38 & 6 & 0 & -1.860646 & 0.924311 & 4.103545 \\
\hline 39 & 6 & 0 & -1.283270 & -0.261674 & 4.563858 \\
\hline 40 & 6 & 0 & -0.139143 & -0.757598 & 3.930771 \\
\hline 41 & 6 & 0 & 0.382097 & -0.059057 & 2.848531 \\
\hline 42 & 6 & 0 & -1.202515 & -3.326571 & 1.217801 \\
\hline 43 & 6 & 0 & -0.243604 & -2.735268 & 0.170812 \\
\hline 44 & 6 & 0 & 1.191097 & -3.113191 & 0.615871 \\
\hline 45 & 6 & 0 & 2.194676 & -3.015534 & -1.651464 \\
\hline 46 & 6 & 0 & 3.313068 & -2.365225 & -2.442623 \\
\hline 47 & 6 & 0 & 3.862854 & -2.942175 & -3.584218 \\
\hline 48 & 6 & 0 & 4.883099 & -2.273649 & -4.265342 \\
\hline 49 & 6 & 0 & 5.339084 & -1.045799 & -3.780391 \\
\hline 50 & 6 & 0 & 4.753973 & -0.526718 & -2.631218 \\
\hline 51 & 6 & 0 & 3.585440 & -3.168893 & 0.360030 \\
\hline 52 & 6 & 0 & 4.271256 & -2.160474 & 1.254190 \\
\hline 53 & 6 & 0 & 5.133056 & -2.539408 & 2.282539 \\
\hline 54 & 6 & 0 & 5.811288 & -1.558167 & 3.007613 \\
\hline 55 & 6 & 0 & 5.597675 & -0.210152 & 2.703741 \\
\hline 56 & 6 & 0 & 4.714708 & 0.106867 & 1.680050 \\
\hline 57 & 1 & 0 & -5.286444 & 2.309565 & -3.041964 \\
\hline 58 & 1 & 0 & -7.179145 & 0.761164 & -2.621490 \\
\hline 59 & 1 & 0 & -7.985956 & -1.469702 & -1.539936 \\
\hline 60 & 1 & 0 & -7.425568 & -3.492612 & -0.244568 \\
\hline 61 & 1 & 0 & -5.616153 & -4.896613 & 0.996160 \\
\hline 62 & 1 & 0 & -3.242669 & -5.093851 & 1.688614 \\
\hline 63 & 1 & 0 & -3.031173 & 3.019453 & -2.535500 \\
\hline 64 & 1 & 0 & -2.146968 & 1.612500 & -3.106777 \\
\hline 65 & 1 & 0 & -0.884234 & 2.814755 & -1.468524 \\
\hline 66 & 1 & 0 & -2.968184 & 3.580582 & -0.052518 \\
\hline 67 & 1 & 0 & -2.872708 & 1.970535 & 0.672323 \\
\hline 68 & 1 & 0 & -0.520166 & 5.070380 & 1.916192 \\
\hline 69 & 1 & 0 & -1.772928 & 5.273743 & 0.697049 \\
\hline 70 & 1 & 0 & -0.243849 & 6.830338 & -0.654562 \\
\hline 71 & 1 & 0 & 1.742305 & 6.974100 & -2.168126 \\
\hline 72 & 1 & 0 & 3.262623 & 4.986730 & -2.367032 \\
\hline 73 & 1 & 0 & 2.699658 & 2.914354 & -1.051571 \\
\hline 74 & 1 & 0 & -2.785324 & 3.105442 & 2.699969 \\
\hline 75 & 1 & 0 & -1.222899 & 3.698552 & 3.242081 \\
\hline 76 & 1 & 0 & -2.738298 & 1.341464 & 4.587113 \\
\hline 77 & 1 & 0 & -1.712503 & -0.781922 & 5.414785 \\
\hline 78 & 1 & 0 & 0.347659 & -1.660916 & 4.282304 \\
\hline 79 & 1 & 0 & 1.252651 & -0.387428 & 2.294977 \\
\hline
\end{tabular}




$\begin{array}{rrrrrr}80 & 1 & 0 & -0.964774 & -4.373865 & 1.421165 \\ 81 & 1 & 0 & -1.076939 & -2.771836 & 2.157114 \\ 82 & 1 & 0 & -0.447537 & -3.208924 & -0.801209 \\ 83 & 1 & 0 & 1.360093 & -2.715733 & 1.621631 \\ 84 & 1 & 0 & 1.198370 & -4.212364 & 0.687456 \\ 85 & 1 & 0 & 1.239784 & -2.627553 & -2.020674 \\ 86 & 1 & 0 & 2.203212 & -4.101737 & -1.818716 \\ 87 & 1 & 0 & 3.501468 & -3.905394 & -3.929905 \\ 88 & 1 & 0 & 5.324313 & -2.711860 & -5.155267 \\ 89 & 1 & 0 & 6.138151 & -0.502563 & -4.272798 \\ 90 & 1 & 0 & 5.074878 & 0.417167 & -2.203420 \\ 91 & 1 & 0 & 4.276834 & -3.406293 & -0.454346 \\ 92 & 1 & 0 & 3.429794 & -4.106947 & 0.905761 \\ 93 & 1 & 0 & 5.277507 & -3.592484 & 2.502671 \\ 94 & 1 & 0 & 6.495735 & -1.840977 & 3.801619 \\ 95 & 1 & 0 & 6.104511 & 0.580679 & 3.245671 \\ 96 & 1 & 0 & 4.488162 & 1.131407 & 1.403362 \\ 97 & 8 & 0 & 1.618307 & 0.676616 & -1.416775 \\ 98 & 1 & 0 & 0.669230 & 0.480191 & -1.201618\end{array}$

TS0"

\begin{tabular}{rrrrrr} 
Center & Atomic & Atomic & \multicolumn{3}{c}{ Coordinates (Angstroms) } \\
Number & Number & Type & X & Y & Z \\
----1 & 29 & 0 & -2.056327 & -0.602832 & -0.116713 \\
1 & 29 & 0 & 0.303448 & 1.854712 & 0.189760 \\
2 & 29 & 0 & 2.759217 & -0.674021 & -0.664908 \\
3 & 8 & 0 & -1.159006 & 0.784609 & -0.977790 \\
4 & 8 & 0 & -0.526515 & -0.761587 & 0.861976 \\
5 & 8 & 0 & 1.898024 & 0.905767 & 0.091680 \\
6 & 7 & 0 & -3.777937 & -0.259996 & -0.955829 \\
7 & 7 & 0 & -3.058896 & -1.793882 & 1.074833 \\
8 & 7 & 0 & -1.449870 & 2.990559 & 0.553016 \\
9 & 7 & 0 & 0.705497 & 3.581714 & -0.977671 \\
10 & 7 & 0 & 0.390589 & 1.931203 & 2.251506 \\
11 & 7 & 0 & 2.300396 & -2.293111 & 0.733137 \\
12 & 7 & 0 & 3.591202 & -2.236100 & -1.625286 \\
13 & 7 & 0 & 4.286247 & -0.274521 & 0.934372 \\
14 & 6 & 0 & -4.042740 & 0.513490 & -2.009032 \\
15 & 6 & 0 & -5.359050 & 0.555564 & -2.531809 \\
16 & 6 & 0 & -6.367058 & -0.200996 & -1.967931 \\
17 & & & & &
\end{tabular}




\begin{tabular}{|c|c|c|c|c|c|}
\hline 18 & 6 & 0 & -6.087811 & -1.028968 & -0.851761 \\
\hline 19 & 6 & 0 & -7.046207 & -1.855930 & -0.174588 \\
\hline 20 & 6 & 0 & -6.681083 & -2.627518 & 0.895154 \\
\hline 21 & 6 & 0 & -5.326864 & -2.639110 & 1.371020 \\
\hline 22 & 6 & 0 & -4.847770 & -3.417153 & 2.454156 \\
\hline 23 & 6 & 0 & -3.513133 & -3.360197 & 2.801455 \\
\hline 24 & 6 & 0 & -2.609609 & -2.532159 & 2.088740 \\
\hline 25 & 6 & 0 & -4.758428 & -1.023335 & -0.386354 \\
\hline 26 & 6 & 0 & -4.376461 & -1.832602 & 0.714719 \\
\hline 27 & 6 & 0 & -2.916563 & 1.299302 & -2.618929 \\
\hline 28 & 6 & 0 & -1.888514 & 1.814023 & -1.605776 \\
\hline 29 & 6 & 0 & -2.458425 & 2.765905 & -0.533152 \\
\hline 30 & 6 & 0 & -0.950632 & 4.391392 & 0.587159 \\
\hline 31 & 6 & 0 & -0.041922 & 4.640657 & -0.594180 \\
\hline 32 & 6 & 0 & 0.049712 & 5.875341 & -1.228982 \\
\hline 33 & 6 & 0 & 0.947304 & 6.023939 & -2.289091 \\
\hline 34 & 6 & 0 & 1.712450 & 4.927598 & -2.687232 \\
\hline 35 & 6 & 0 & 1.557888 & 3.723430 & -2.006872 \\
\hline 36 & 6 & 0 & -1.921008 & 2.531544 & 1.884951 \\
\hline 37 & 6 & 0 & -0.757744 & 2.328033 & 2.832505 \\
\hline 38 & 6 & 0 & -0.856934 & 2.488044 & 4.212511 \\
\hline 39 & 6 & 0 & 0.262320 & 2.214424 & 5.002910 \\
\hline 40 & 6 & 0 & 1.446568 & 1.799178 & 4.389920 \\
\hline 41 & 6 & 0 & 1.473541 & 1.675927 & 3.004013 \\
\hline 42 & 6 & 0 & -1.149996 & -2.470624 & 2.464528 \\
\hline 43 & 6 & 0 & -0.239407 & -2.063517 & 1.291749 \\
\hline 44 & 6 & 0 & 1.232129 & -2.120363 & 1.759772 \\
\hline 45 & 6 & 0 & 2.058510 & -3.434552 & -0.193730 \\
\hline 46 & 6 & 0 & 3.115631 & -3.447504 & -1.273133 \\
\hline 47 & 6 & 0 & 3.559866 & -4.605069 & -1.901622 \\
\hline 48 & 6 & 0 & 4.503203 & -4.494719 & -2.927122 \\
\hline 49 & 6 & 0 & 4.978859 & -3.233571 & -3.287342 \\
\hline 50 & 6 & 0 & 4.496804 & -2.117559 & -2.608906 \\
\hline 51 & 6 & 0 & 3.592866 & -2.510635 & 1.469124 \\
\hline 52 & 6 & 0 & 4.244609 & -1.217334 & 1.890479 \\
\hline 53 & 6 & 0 & 4.827802 & -1.029042 & 3.142778 \\
\hline 54 & 6 & 0 & 5.492526 & 0.173123 & 3.397636 \\
\hline 55 & 6 & 0 & 5.539779 & 1.148279 & 2.399577 \\
\hline 56 & 6 & 0 & 4.912612 & 0.883533 & 1.182958 \\
\hline 57 & 1 & 0 & -5.557881 & 1.190763 & -3.387942 \\
\hline 58 & 1 & 0 & -7.373281 & -0.164265 & -2.375262 \\
\hline 59 & 1 & 0 & -8.072263 & -1.859191 & -0.528429 \\
\hline 60 & 1 & 0 & -7.414101 & -3.250908 & 1.397217 \\
\hline 61 & 1 & 0 & -5.530322 & -4.060973 & 3.001189 \\
\hline
\end{tabular}




\begin{tabular}{|c|c|c|c|c|c|}
\hline 62 & 1 & 0 & -3.132773 & -3.955758 & 3.624320 \\
\hline 63 & 1 & 0 & -3.321787 & 2.131231 & -3.202085 \\
\hline 64 & 1 & 0 & -2.369346 & 0.646214 & -3.311937 \\
\hline 65 & 1 & 0 & -1.138477 & 2.354179 & -2.198926 \\
\hline 66 & 1 & 0 & -2.747568 & 3.720337 & -0.981804 \\
\hline 67 & 1 & 0 & -3.357006 & 2.329158 & -0.088525 \\
\hline 68 & 1 & 0 & -0.375420 & 4.517789 & 1.510483 \\
\hline 69 & 1 & 0 & -1.780317 & 5.107485 & 0.614972 \\
\hline 70 & 1 & 0 & -0.568371 & 6.704692 & -0.900751 \\
\hline 71 & 1 & 0 & 1.038560 & 6.976985 & -2.800284 \\
\hline 72 & 1 & 0 & 2.409084 & 4.995609 & -3.515278 \\
\hline 73 & 1 & 0 & 2.101227 & 2.835401 & -2.294175 \\
\hline 74 & 1 & 0 & -2.405436 & 1.560459 & 1.734610 \\
\hline 75 & 1 & 0 & -2.666140 & 3.216937 & 2.307982 \\
\hline 76 & 1 & 0 & -1.785783 & 2.827725 & 4.659130 \\
\hline 77 & 1 & 0 & 0.212577 & 2.337163 & 6.080254 \\
\hline 78 & 1 & 0 & 2.338685 & 1.590785 & 4.969872 \\
\hline 79 & 1 & 0 & 2.363335 & 1.378847 & 2.458799 \\
\hline 80 & 1 & 0 & -0.862482 & -3.447602 & 2.865543 \\
\hline 81 & 1 & 0 & -1.031101 & -1.741868 & 3.278562 \\
\hline 82 & 1 & 0 & -0.391584 & -2.771891 & 0.468636 \\
\hline 83 & 1 & 0 & 1.457384 & -1.202366 & 2.309633 \\
\hline 84 & 1 & 0 & 1.312050 & -2.960624 & 2.463359 \\
\hline 85 & 1 & 0 & 1.093035 & -3.277136 & -0.678457 \\
\hline 86 & 1 & 0 & 2.034012 & -4.389215 & 0.348012 \\
\hline 87 & 1 & 0 & 3.176451 & -5.573022 & -1.596404 \\
\hline 88 & 1 & 0 & 4.863640 & -5.384052 & -3.434155 \\
\hline 89 & 1 & 0 & 5.711405 & -3.110146 & -4.076857 \\
\hline 90 & 1 & 0 & 4.805194 & -1.105280 & -2.841389 \\
\hline 91 & 1 & 0 & 4.280421 & -3.020402 & 0.790539 \\
\hline 92 & 1 & 0 & 3.434096 & -3.174985 & 2.326194 \\
\hline 93 & 1 & 0 & 4.778989 & -1.810918 & 3.893841 \\
\hline 94 & 1 & 0 & 5.971076 & 0.342237 & 4.357228 \\
\hline 95 & 1 & 0 & 6.054708 & 2.090075 & 2.554236 \\
\hline 96 & 1 & 0 & 4.907748 & 1.614984 & 0.381126 \\
\hline 97 & 8 & 0 & 1.016906 & -1.204370 & -1.918583 \\
\hline 98 & 6 & 0 & 0.543155 & -0.423142 & -2.846630 \\
\hline 99 & 8 & 0 & 1.126136 & 0.664614 & -3.188905 \\
\hline 100 & 8 & 0 & -0.528518 & -0.849854 & -3.357691 \\
\hline 101 & 8 & 0 & -1.697556 & -2.411696 & -1.493188 \\
\hline 102 & 1 & 0 & -2.434199 & -2.909535 & -1.869430 \\
\hline 103 & 1 & 0 & -1.226483 & -1.998801 & -2.258696 \\
\hline 104 & 8 & 0 & 3.266017 & 0.593174 & -2.097546 \\
\hline 105 & 1 & 0 & 3.627089 & 1.420060 & -1.752042 \\
\hline
\end{tabular}


TS1"

\begin{tabular}{|c|c|c|c|c|c|}
\hline \multirow{2}{*}{$\begin{array}{l}\text { Center } \\
\text { Number }\end{array}$} & \multirow{2}{*}{$\begin{array}{l}\text { Atomic } \\
\text { Number }\end{array}$} & \multirow{2}{*}{$\begin{array}{l}\text { Atomic } \\
\text { Type }\end{array}$} & \multicolumn{3}{|c|}{ Coordinates (Angstroms) } \\
\hline & & & $\mathrm{X}$ & $\mathrm{Y}$ & $\mathrm{Z}$ \\
\hline 1 & 29 & 0 & -1.964050 & -0.678843 & -0.201309 \\
\hline 2 & 29 & 0 & 0.358747 & 2.045615 & 0.383030 \\
\hline 3 & 29 & 0 & 2.698547 & -0.501277 & -0.520704 \\
\hline 4 & 8 & 0 & -1.076639 & 0.862827 & -0.789782 \\
\hline 5 & 8 & 0 & -0.454402 & -1.031738 & 0.771307 \\
\hline 6 & 8 & 0 & 2.053521 & 1.234630 & 0.257547 \\
\hline 7 & 7 & 0 & -3.662193 & -0.215330 & -1.043092 \\
\hline 8 & 7 & 0 & -3.040337 & -1.975948 & 0.829950 \\
\hline 9 & 7 & 0 & -1.486784 & 2.967026 & 0.782790 \\
\hline 10 & 7 & 0 & 0.689585 & 3.905851 & -0.478984 \\
\hline 11 & 7 & 0 & 0.224056 & 1.538034 & 2.368729 \\
\hline 12 & 7 & 0 & 2.261359 & -2.543390 & 0.435599 \\
\hline 13 & 7 & 0 & 3.664926 & -1.857841 & -1.772627 \\
\hline 14 & 7 & 0 & 4.072978 & -0.532219 & 1.035462 \\
\hline 15 & 6 & 0 & -3.875599 & 0.650713 & -2.034812 \\
\hline 16 & 6 & 0 & -5.176277 & 0.783648 & -2.581548 \\
\hline 17 & 6 & 0 & -6.222839 & 0.018727 & -2.108007 \\
\hline 18 & 6 & 0 & -5.997461 & -0.914192 & -1.065612 \\
\hline 19 & 6 & 0 & -6.999226 & -1.767360 & -0.492440 \\
\hline 20 & 6 & 0 & -6.685895 & -2.651759 & 0.503303 \\
\hline 21 & 6 & 0 & -5.344024 & -2.759448 & 1.000470 \\
\hline 22 & 6 & 0 & -4.917935 & -3.664147 & 2.003908 \\
\hline 23 & 6 & 0 & -3.589471 & -3.697348 & 2.374870 \\
\hline 24 & 6 & 0 & -2.642359 & -2.836382 & 1.765554 \\
\hline 25 & 6 & 0 & -4.680357 & -0.996302 & -0.571678 \\
\hline 26 & 6 & 0 & -4.351257 & -1.925263 & 0.448519 \\
\hline 27 & 6 & 0 & -2.710648 & 1.439799 & -2.551869 \\
\hline 28 & 6 & 0 & -1.747606 & 1.907743 & -1.455963 \\
\hline 29 & 6 & 0 & -2.374615 & 2.868379 & -0.422554 \\
\hline 30 & 6 & 0 & -1.090004 & 4.364079 & 1.094615 \\
\hline 31 & 6 & 0 & -0.131487 & 4.852624 & 0.032859 \\
\hline 32 & 6 & 0 & -0.071827 & 6.177892 & -0.384582 \\
\hline 33 & 6 & 0 & 0.866209 & 6.539351 & -1.354618 \\
\hline 34 & 6 & 0 & 1.707269 & 5.559454 & -1.882343 \\
\hline 35 & 6 & 0 & 1.586631 & 4.253189 & -1.418059 \\
\hline
\end{tabular}




\begin{tabular}{|c|c|c|c|c|c|}
\hline 36 & 6 & 0 & -2.052427 & 2.258307 & 1.956901 \\
\hline 37 & 6 & 0 & -0.977937 & 1.797458 & 2.915994 \\
\hline 38 & 6 & 0 & -1.225965 & 1.571780 & 4.268835 \\
\hline 39 & 6 & 0 & -0.204594 & 1.046910 & 5.062309 \\
\hline 40 & 6 & 0 & 1.035122 & 0.769018 & 4.480938 \\
\hline 41 & 6 & 0 & 1.212780 & 1.036800 & 3.128041 \\
\hline 42 & 6 & 0 & -1.187942 & -2.880234 & 2.155761 \\
\hline 43 & 6 & 0 & -0.258275 & -2.393982 & 1.030094 \\
\hline 44 & 6 & 0 & 1.201783 & -2.630357 & 1.467753 \\
\hline 45 & 6 & 0 & 2.032377 & -3.366933 & -0.774456 \\
\hline 46 & 6 & 0 & 3.112583 & -3.087056 & -1.802703 \\
\hline 47 & 6 & 0 & 3.507166 & -4.027001 & -2.750536 \\
\hline 48 & 6 & 0 & 4.473430 & -3.672888 & -3.694932 \\
\hline 49 & 6 & 0 & 5.029282 & -2.393143 & -3.659109 \\
\hline 50 & 6 & 0 & 4.594693 & -1.510404 & -2.674773 \\
\hline 51 & 6 & 0 & 3.557323 & -2.903331 & 1.072722 \\
\hline 52 & 6 & 0 & 4.259398 & -1.709138 & 1.663752 \\
\hline 53 & 6 & 0 & 5.114072 & -1.823838 & 2.760655 \\
\hline 54 & 6 & 0 & 5.806092 & -0.699309 & 3.206504 \\
\hline 55 & 6 & 0 & 5.605165 & 0.519370 & 2.554011 \\
\hline 56 & 6 & 0 & 4.723199 & 0.558859 & 1.481720 \\
\hline 57 & 1 & 0 & -5.330516 & 1.494679 & -3.385522 \\
\hline 58 & 1 & 0 & -7.216959 & 0.125571 & -2.532300 \\
\hline 59 & 1 & 0 & -8.015513 & -1.700263 & -0.867460 \\
\hline 60 & 1 & 0 & -7.450413 & -3.295746 & 0.926114 \\
\hline 61 & 1 & 0 & -5.635515 & -4.334287 & 2.468197 \\
\hline 62 & 1 & 0 & -3.246373 & -4.391722 & 3.134190 \\
\hline 63 & 1 & 0 & -3.069029 & 2.298040 & -3.127211 \\
\hline 64 & 1 & 0 & -2.121577 & 0.805910 & -3.229260 \\
\hline 65 & 1 & 0 & -0.950738 & 2.441223 & -1.994235 \\
\hline 66 & 1 & 0 & -2.505404 & 3.859167 & -0.864553 \\
\hline 67 & 1 & 0 & -3.362793 & 2.520203 & -0.106602 \\
\hline 68 & 1 & 0 & -0.583296 & 4.356434 & 2.066513 \\
\hline 69 & 1 & 0 & -1.964361 & 5.020012 & 1.180406 \\
\hline 70 & 1 & 0 & -0.747295 & 6.913200 & 0.040227 \\
\hline 71 & 1 & 0 & 0.931824 & 7.567188 & -1.696972 \\
\hline 72 & 1 & 0 & 2.440846 & 5.796018 & -2.644877 \\
\hline 73 & 1 & 0 & 2.208116 & 3.453282 & -1.797836 \\
\hline 74 & 1 & 0 & -2.556524 & 1.364067 & 1.578477 \\
\hline 75 & 1 & 0 & -2.806906 & 2.872004 & 2.464864 \\
\hline 76 & 1 & 0 & -2.196493 & 1.808633 & 4.692771 \\
\hline 77 & 1 & 0 & -0.370530 & 0.869271 & 6.120211 \\
\hline 78 & 1 & 0 & 1.855488 & 0.371951 & 5.068461 \\
\hline 79 & 1 & 0 & 2.151181 & 0.860968 & 2.615050 \\
\hline
\end{tabular}




\begin{tabular}{|c|c|c|c|c|c|}
\hline 80 & 1 & 0 & -0.948523 & -3.904362 & 2.458500 \\
\hline 81 & 1 & 0 & -1.042050 & -2.240396 & 3.037271 \\
\hline 82 & 1 & 0 & -0.455015 & -2.984019 & 0.125900 \\
\hline 83 & 1 & 0 & 1.452975 & -1.905968 & 2.249605 \\
\hline 84 & 1 & 0 & 1.235249 & -3.634115 & 1.918416 \\
\hline 85 & 1 & 0 & 1.073389 & -3.074799 & -1.207627 \\
\hline 86 & 1 & 0 & 2.004501 & -4.438972 & -0.532942 \\
\hline 87 & 1 & 0 & 3.064849 & -5.017899 & -2.750574 \\
\hline 88 & 1 & 0 & 4.791231 & -4.389526 & -4.445486 \\
\hline 89 & 1 & 0 & 5.783755 & -2.083132 & -4.373228 \\
\hline 90 & 1 & 0 & 4.978454 & -0.497879 & -2.596583 \\
\hline 91 & 1 & 0 & 4.215497 & -3.327844 & 0.310406 \\
\hline 92 & 1 & 0 & 3.420493 & -3.682217 & 1.832998 \\
\hline 93 & 1 & 0 & 5.239455 & -2.785453 & 3.247733 \\
\hline 94 & 1 & 0 & 6.485798 & -0.770072 & 4.049773 \\
\hline 95 & 1 & 0 & 6.117305 & 1.421770 & 2.868577 \\
\hline 96 & 1 & 0 & 4.503126 & 1.487034 & 0.971847 \\
\hline 97 & 8 & 0 & 1.216335 & -0.774933 & -1.760759 \\
\hline 98 & 6 & 0 & 0.617339 & -0.089692 & -2.672590 \\
\hline 99 & 8 & 0 & 1.030937 & 1.159998 & -2.948036 \\
\hline 100 & 8 & 0 & -0.351338 & -0.536221 & -3.310582 \\
\hline 101 & 8 & 0 & -1.515535 & -2.245781 & -1.780049 \\
\hline 102 & 1 & 0 & -2.226586 & -2.681719 & -2.265786 \\
\hline 103 & 1 & 0 & -1.009209 & -1.693360 & -2.459895 \\
\hline 104 & 8 & 0 & 3.143039 & 1.363799 & -1.317363 \\
\hline 105 & 1 & 0 & 3.726584 & 1.964814 & -0.831663 \\
\hline 106 & 1 & 0 & 1.839646 & 1.351462 & -2.429856 \\
\hline
\end{tabular}

\section{Int1}

\begin{tabular}{|c|c|c|c|c|c|}
\hline \multirow{2}{*}{$\begin{array}{l}\text { Center } \\
\text { Number }\end{array}$} & \multirow{2}{*}{$\begin{array}{l}\text { Atomic } \\
\text { Number }\end{array}$} & \multirow{2}{*}{$\begin{array}{l}\text { Atomic } \\
\text { Type }\end{array}$} & \multicolumn{3}{|c|}{ Coordinates (Angstroms) } \\
\hline & & & $\mathrm{X}$ & $\mathrm{Y}$ & $\mathrm{Z}$ \\
\hline 1 & 29 & 0 & -2.103536 & -0.509616 & -0.272088 \\
\hline 2 & 29 & 0 & 0.891431 & 2.102306 & 0.117241 \\
\hline 3 & 29 & 0 & 2.247848 & -1.113347 & -0.258209 \\
\hline 4 & 8 & 0 & -0.973180 & 0.926869 & -0.719612 \\
\hline 5 & 8 & 0 & -0.686792 & -1.279370 & 0.648498 \\
\hline 6 & 8 & 0 & 2.134482 & 0.806258 & -0.659338 \\
\hline 7 & 7 & 0 & -3.730274 & 0.356416 & -0.963445 \\
\hline 8 & 7 & 0 & -3.387420 & -1.796269 & 0.508434 \\
\hline 9 & 7 & 0 & -0.511860 & 3.637629 & 0.271763 \\
\hline
\end{tabular}




\begin{tabular}{|c|c|c|c|c|c|}
\hline 10 & 7 & 0 & 2.096985 & 3.630812 & -0.500178 \\
\hline 11 & 7 & 0 & 0.216217 & 1.664417 & 2.037566 \\
\hline 12 & 7 & 0 & 1.941081 & -3.042281 & 0.459047 \\
\hline 13 & 7 & 0 & 3.692851 & -2.362155 & -1.516831 \\
\hline 14 & 7 & 0 & 3.292527 & -0.891982 & 1.432607 \\
\hline 15 & 6 & 0 & -3.809802 & 1.332295 & -1.864322 \\
\hline 16 & 6 & 0 & -5.074311 & 1.809680 & -2.286595 \\
\hline 17 & 6 & 0 & -6.235318 & 1.240096 & -1.805985 \\
\hline 18 & 6 & 0 & -6.157541 & 0.146486 & -0.910275 \\
\hline 19 & 6 & 0 & -7.285148 & -0.573129 & -0.392880 \\
\hline 20 & 6 & 0 & -7.111758 & -1.666437 & 0.410313 \\
\hline 21 & 6 & 0 & -5.798030 & -2.129828 & 0.752413 \\
\hline 22 & 6 & 0 & -5.524932 & -3.294631 & 1.509490 \\
\hline 23 & 6 & 0 & -4.217332 & -3.668621 & 1.726953 \\
\hline 24 & 6 & 0 & -3.142820 & -2.896608 & 1.215311 \\
\hline 25 & 6 & 0 & -4.863494 & -0.267657 & -0.532614 \\
\hline 26 & 6 & 0 & -4.681868 & -1.412231 & 0.277860 \\
\hline 27 & 6 & 0 & -2.530217 & 1.845573 & -2.437749 \\
\hline 28 & 6 & 0 & -1.443214 & 2.078311 & -1.385296 \\
\hline 29 & 6 & 0 & -1.789951 & 3.131265 & -0.318258 \\
\hline 30 & 6 & 0 & -0.004223 & 4.812973 & -0.493943 \\
\hline 31 & 6 & 0 & 1.503743 & 4.840891 & -0.542943 \\
\hline 32 & 6 & 0 & 2.236645 & 6.006748 & -0.741749 \\
\hline 33 & 6 & 0 & 3.617506 & 5.907889 & -0.927095 \\
\hline 34 & 6 & 0 & 4.219574 & 4.648012 & -0.915211 \\
\hline 35 & 6 & 0 & 3.423902 & 3.528972 & -0.694207 \\
\hline 36 & 6 & 0 & -0.595655 & 3.931343 & 1.725884 \\
\hline 37 & 6 & 0 & -0.548102 & 2.658440 & 2.541745 \\
\hline 38 & 6 & 0 & -1.200444 & 2.532076 & 3.764985 \\
\hline 39 & 6 & 0 & -1.039411 & 1.353175 & 4.496747 \\
\hline 40 & 6 & 0 & -0.247191 & 0.332334 & 3.970979 \\
\hline 41 & 6 & 0 & 0.354332 & 0.525128 & 2.731258 \\
\hline 42 & 6 & 0 & -1.732407 & -3.312942 & 1.508135 \\
\hline 43 & 6 & 0 & -0.646924 & -2.680494 & 0.620401 \\
\hline 44 & 6 & 0 & 0.689187 & -3.180941 & 1.238736 \\
\hline 45 & 6 & 0 & 1.992776 & -3.924927 & -0.737280 \\
\hline 46 & 6 & 0 & 3.203450 & -3.612882 & -1.602614 \\
\hline 47 & 6 & 0 & 3.745050 & -4.566744 & -2.461548 \\
\hline 48 & 6 & 0 & 4.817285 & -4.201033 & -3.277683 \\
\hline 49 & 6 & 0 & 5.319043 & -2.901629 & -3.197166 \\
\hline 50 & 6 & 0 & 4.728263 & -2.016740 & -2.297849 \\
\hline 51 & 6 & 0 & 3.097880 & -3.304336 & 1.367572 \\
\hline 52 & 6 & 0 & 3.537033 & -2.048205 & 2.082581 \\
\hline 53 & 6 & 0 & 4.229680 & -2.064652 & 3.291842 \\
\hline
\end{tabular}




\begin{tabular}{|c|c|c|c|c|c|}
\hline 54 & 6 & 0 & 4.695244 & -0.860250 & 3.820760 \\
\hline 55 & 6 & 0 & 4.450963 & 0.330676 & 3.130385 \\
\hline 56 & 6 & 0 & 3.740198 & 0.272314 & 1.938772 \\
\hline 57 & 1 & 0 & -5.110225 & 2.616911 & -3.009500 \\
\hline 58 & 1 & 0 & -7.204672 & 1.606729 & -2.130775 \\
\hline 59 & 1 & 0 & -8.282647 & -0.242759 & -0.664512 \\
\hline 60 & 1 & 0 & -7.969775 & -2.216891 & 0.782726 \\
\hline 61 & 1 & 0 & -6.342857 & -3.892056 & 1.901357 \\
\hline 62 & 1 & 0 & -3.985590 & -4.563671 & 2.294135 \\
\hline 63 & 1 & 0 & -2.705589 & 2.769870 & -2.994153 \\
\hline 64 & 1 & 0 & -2.137996 & 1.104829 & -3.143407 \\
\hline 65 & 1 & 0 & -0.586521 & 2.428087 & -1.987304 \\
\hline 66 & 1 & 0 & -2.379082 & 3.970268 & -0.706928 \\
\hline 67 & 1 & 0 & -2.367454 & 2.641723 & 0.469073 \\
\hline 68 & 1 & 0 & -0.421288 & 5.744799 & -0.095367 \\
\hline 69 & 1 & 0 & -0.361724 & 4.717987 & -1.524367 \\
\hline 70 & 1 & 0 & 1.737192 & 6.969812 & -0.765135 \\
\hline 71 & 1 & 0 & 4.212169 & 6.801545 & -1.087490 \\
\hline 72 & 1 & 0 & 5.285731 & 4.532339 & -1.074378 \\
\hline 73 & 1 & 0 & 3.817949 & 2.519361 & -0.685679 \\
\hline 74 & 1 & 0 & -1.489565 & 4.522051 & 1.957886 \\
\hline 75 & 1 & 0 & 0.277191 & 4.542168 & 1.983807 \\
\hline 76 & 1 & 0 & -1.812173 & 3.344475 & 4.143380 \\
\hline 77 & 1 & 0 & -1.526242 & 1.236979 & 5.459920 \\
\hline 78 & 1 & 0 & -0.097629 & -0.597086 & 4.509258 \\
\hline 79 & 1 & 0 & 0.951875 & -0.239856 & 2.256856 \\
\hline 80 & 1 & 0 & -1.683523 & -4.405646 & 1.451832 \\
\hline 81 & 1 & 0 & -1.529200 & -3.045776 & 2.555213 \\
\hline 82 & 1 & 0 & -0.735575 & -3.041398 & -0.414389 \\
\hline 83 & 1 & 0 & 0.832121 & -2.630510 & 2.173200 \\
\hline 84 & 1 & 0 & 0.560577 & -4.241339 & 1.497874 \\
\hline 85 & 1 & 0 & 1.091277 & -3.728020 & -1.321419 \\
\hline 86 & 1 & 0 & 1.991490 & -4.981467 & -0.437959 \\
\hline 87 & 1 & 0 & 3.338129 & -5.572566 & -2.494571 \\
\hline 88 & 1 & 0 & 5.256638 & -4.921646 & -3.959950 \\
\hline 89 & 1 & 0 & 6.152892 & -2.580180 & -3.811199 \\
\hline 90 & 1 & 0 & 5.086327 & -0.996857 & -2.192746 \\
\hline 91 & 1 & 0 & 3.936728 & -3.645743 & 0.755802 \\
\hline 92 & 1 & 0 & 2.867912 & -4.107302 & 2.077780 \\
\hline 93 & 1 & 0 & 4.412256 & -3.005430 & 3.800931 \\
\hline 94 & 1 & 0 & 5.245219 & -0.851036 & 4.756484 \\
\hline 95 & 1 & 0 & 4.806571 & 1.283081 & 3.507105 \\
\hline 96 & 1 & 0 & 3.510505 & 1.156753 & 1.354712 \\
\hline 97 & 8 & 0 & 1.014097 & -1.265906 & -1.730683 \\
\hline
\end{tabular}




$\begin{array}{rrrrrr}98 & 6 & 0 & 0.823401 & -0.194186 & -2.386789 \\ 99 & 8 & 0 & 1.571514 & 0.940311 & -2.009637 \\ 100 & 8 & 0 & 0.065596 & -0.003978 & -3.333665 \\ 101 & 8 & 0 & -2.009527 & -1.465144 & -2.356740 \\ 102 & 1 & 0 & -2.102295 & -2.380128 & -2.644740 \\ 103 & 1 & 0 & -1.246287 & -1.085213 & -2.856495\end{array}$

Int1'

\begin{tabular}{|c|c|c|c|c|c|}
\hline \multirow{2}{*}{$\begin{array}{l}\text { Center } \\
\text { Number }\end{array}$} & \multirow{2}{*}{$\begin{array}{l}\text { Atomic } \\
\text { Number }\end{array}$} & \multirow{2}{*}{$\begin{array}{l}\text { Atomic } \\
\text { Type }\end{array}$} & \multicolumn{3}{|c|}{ Coordinates (Angstroms) } \\
\hline & & & $\mathrm{X}$ & $\mathrm{Y}$ & $\mathrm{Z}$ \\
\hline 1 & 29 & 0 & -2.041756 & -0.644796 & -0.517113 \\
\hline 2 & 29 & 0 & 0.203214 & 2.157900 & 0.847016 \\
\hline 3 & 29 & 0 & 3.177580 & -0.212664 & -0.305135 \\
\hline 4 & 8 & 0 & -1.288953 & 1.016784 & -0.805107 \\
\hline 5 & 8 & 0 & -0.303175 & -1.224677 & -0.108896 \\
\hline 6 & 8 & 0 & 1.717922 & 0.963109 & 0.404361 \\
\hline 7 & 7 & 0 & -3.812363 & -0.128663 & -1.151545 \\
\hline 8 & 7 & 0 & -2.895739 & -2.323678 & -0.038985 \\
\hline 9 & 7 & 0 & -1.518960 & 3.294706 & 1.156806 \\
\hline 10 & 7 & 0 & 0.757631 & 3.683475 & -0.298676 \\
\hline 11 & 7 & 0 & -0.446770 & 1.164212 & 2.441571 \\
\hline 12 & 7 & 0 & 2.602821 & -2.401193 & -0.295660 \\
\hline 13 & 7 & 0 & 4.123439 & -0.827931 & -1.971930 \\
\hline 14 & 7 & 0 & 4.395604 & -0.705289 & 1.146136 \\
\hline 15 & 6 & 0 & -4.173292 & 0.980119 & -1.803300 \\
\hline 16 & 6 & 0 & -5.511754 & 1.139548 & -2.234475 \\
\hline 17 & 6 & 0 & -6.448460 & 0.146064 & -2.021696 \\
\hline 18 & 6 & 0 & -6.062290 & -1.054742 & -1.377455 \\
\hline 19 & 6 & 0 & -6.929011 & -2.169250 & -1.117608 \\
\hline 20 & 6 & 0 & -6.460638 & -3.297182 & -0.499107 \\
\hline 21 & 6 & 0 & -5.087070 & -3.401462 & -0.095660 \\
\hline 22 & 6 & 0 & -4.503205 & -4.528895 & 0.532689 \\
\hline 23 & 6 & 0 & -3.162953 & -4.506861 & 0.868824 \\
\hline 24 & 6 & 0 & -2.360107 & -3.377188 & 0.581436 \\
\hline 25 & 6 & 0 & -4.716304 & -1.142325 & -0.967918 \\
\hline 26 & 6 & 0 & -4.228728 & -2.313097 & -0.350262 \\
\hline 27 & 6 & 0 & -3.121775 & 2.000865 & -2.131574 \\
\hline 28 & 6 & 0 & -2.056936 & 2.174970 & -1.045283 \\
\hline 29 & 6 & 0 & -2.601398 & 2.739960 & 0.278171 \\
\hline 30 & 6 & 0 & -1.158331 & 4.704405 & 0.806565 \\
\hline
\end{tabular}




\begin{tabular}{|c|c|c|c|c|c|}
\hline 31 & 6 & 0 & -0.050599 & 4.767125 & -0.222951 \\
\hline 32 & 6 & 0 & 0.182772 & 5.902312 & -0.992841 \\
\hline 33 & 6 & 0 & 1.286416 & 5.923731 & -1.848721 \\
\hline 34 & 6 & 0 & 2.118783 & 4.803419 & -1.916515 \\
\hline 35 & 6 & 0 & 1.818970 & 3.698595 & -1.129944 \\
\hline 36 & 6 & 0 & -1.866051 & 3.127929 & 2.599741 \\
\hline 37 & 6 & 0 & -1.480758 & 1.748818 & 3.088948 \\
\hline 38 & 6 & 0 & -2.070240 & 1.150053 & 4.199583 \\
\hline 39 & 6 & 0 & -1.554113 & -0.060951 & 4.666556 \\
\hline 40 & 6 & 0 & -0.473208 & -0.646640 & 3.999617 \\
\hline 41 & 6 & 0 & 0.048180 & -0.007192 & 2.881298 \\
\hline 42 & 6 & 0 & -0.921877 & -3.310559 & 0.999167 \\
\hline 43 & 6 & 0 & -0.009192 & -2.611267 & -0.026901 \\
\hline 44 & 6 & 0 & 1.439010 & -2.888928 & 0.471985 \\
\hline 45 & 6 & 0 & 2.551446 & -2.695448 & -1.746762 \\
\hline 46 & 6 & 0 & 3.694471 & -2.008510 & -2.477412 \\
\hline 47 & 6 & 0 & 4.275118 & -2.555228 & -3.617712 \\
\hline 48 & 6 & 0 & 5.312445 & -1.867580 & -4.253570 \\
\hline 49 & 6 & 0 & 5.752087 & -0.654034 & -3.721646 \\
\hline 50 & 6 & 0 & 5.134976 & -0.169253 & -2.573974 \\
\hline 51 & 6 & 0 & 3.850269 & -2.952684 & 0.323191 \\
\hline 52 & 6 & 0 & 4.488189 & -2.039643 & 1.353360 \\
\hline 53 & 6 & 0 & 5.239086 & -2.543416 & 2.412831 \\
\hline 54 & 6 & 0 & 5.918369 & -1.658667 & 3.253592 \\
\hline 55 & 6 & 0 & 5.818653 & -0.284287 & 3.023787 \\
\hline 56 & 6 & 0 & 5.038838 & 0.156342 & 1.961861 \\
\hline 57 & 1 & 0 & -5.784398 & 2.052579 & -2.752534 \\
\hline 58 & 1 & 0 & -7.473182 & 0.278017 & -2.358132 \\
\hline 59 & 1 & 0 & -7.968514 & -2.102066 & -1.423261 \\
\hline 60 & 1 & 0 & -7.123588 & -4.136353 & -0.312612 \\
\hline 61 & 1 & 0 & -5.108528 & -5.404758 & 0.749371 \\
\hline 62 & 1 & 0 & -2.705601 & -5.358579 & 1.360424 \\
\hline 63 & 1 & 0 & -3.592311 & 2.962143 & -2.354098 \\
\hline 64 & 1 & 0 & -2.616031 & 1.676260 & -3.050334 \\
\hline 65 & 1 & 0 & -1.339582 & 2.888547 & -1.475281 \\
\hline 66 & 1 & 0 & -3.356610 & 3.515966 & 0.106062 \\
\hline 67 & 1 & 0 & -3.079068 & 1.918770 & 0.819821 \\
\hline 68 & 1 & 0 & -0.797081 & 5.197479 & 1.714306 \\
\hline 69 & 1 & 0 & -2.039075 & 5.264076 & 0.473695 \\
\hline 70 & 1 & 0 & -0.478472 & 6.759648 & -0.915643 \\
\hline 71 & 1 & 0 & 1.492250 & 6.801933 & -2.452875 \\
\hline 72 & 1 & 0 & 2.984029 & 4.786475 & -2.569586 \\
\hline 73 & 1 & 0 & 2.412413 & 2.794130 & -1.144307 \\
\hline 74 & 1 & 0 & -2.925029 & 3.340616 & 2.783135 \\
\hline
\end{tabular}




$\begin{array}{lllrrr}75 & 1 & 0 & -1.289216 & 3.857044 & 3.177110 \\ 76 & 1 & 0 & -2.898954 & 1.634990 & 4.705657 \\ 77 & 1 & 0 & -1.982093 & -0.533148 & 5.545589 \\ 78 & 1 & 0 & -0.034246 & -1.573467 & 4.352966 \\ 79 & 1 & 0 & 0.874353 & -0.399252 & 2.302078 \\ 80 & 1 & 0 & -0.570712 & -4.325048 & 1.200458 \\ 81 & 1 & 0 & -0.864740 & -2.751788 & 1.943234 \\ 82 & 1 & 0 & -0.146592 & -3.085050 & -1.009043 \\ 83 & 1 & 0 & 1.543065 & -2.493564 & 1.487572 \\ 84 & 1 & 0 & 1.493709 & -3.986025 & 0.541376 \\ 85 & 1 & 0 & 1.605815 & -2.301773 & -2.135049 \\ 86 & 1 & 0 & 2.572025 & -3.773744 & -1.956375 \\ 87 & 1 & 0 & 3.928277 & -3.510245 & -3.999055 \\ 88 & 1 & 0 & 5.779132 & -2.281590 & -5.141981 \\ 89 & 1 & 0 & 6.564095 & -0.097540 & -4.176498 \\ 90 & 1 & 0 & 5.450712 & 0.758680 & -2.109075 \\ 91 & 1 & 0 & 4.585627 & -3.097437 & -0.473897 \\ 92 & 1 & 0 & 3.673003 & -3.942355 & 0.759658 \\ 93 & 1 & 0 & 5.305705 & -3.615604 & 2.567549 \\ 94 & 1 & 0 & 6.518823 & -2.037431 & 4.074938 \\ 95 & 1 & 0 & 6.334922 & 0.433730 & 3.651280 \\ 96 & 1 & 0 & 4.917535 & 1.211096 & 1.739874 \\ 97 & 8 & 0 & 1.425074 & 0.533684 & -0.972749 \\ 98 & 1 & 0 & 0.700706 & -0.152584 & -0.799192\end{array}$

Int0"

\begin{tabular}{rrrrrr} 
Center & Atomic & Atomic & \multicolumn{3}{c}{ Coordinates (Angstroms) } \\
Number & Number & Type & X & $Y$ & $Z$ \\
-1 & 29 & 0 & -2.016363 & -0.648654 & -0.131162 \\
2 & 29 & 0 & 0.265743 & 1.909255 & 0.258615 \\
3 & 29 & 0 & 2.713033 & -0.606669 & -0.538824 \\
4 & 8 & 0 & -1.109940 & 0.771729 & -0.932356 \\
5 & 8 & 0 & -0.526692 & -0.811962 & 0.907534 \\
6 & 8 & 0 & 1.866486 & 0.952550 & 0.305846 \\
7 & 7 & 0 & -3.702629 & -0.321672 & -1.038666 \\
8 & 7 & 0 & -3.062562 & -1.833384 & 1.035249 \\
9 & 7 & 0 & -1.522950 & 3.027548 & 0.463468 \\
10 & 7 & 0 & 0.738219 & 3.613164 & -0.905819 \\
11 & 7 & 0 & 0.181090 & 2.004624 & 2.321071 \\
12 & 7 & 0 & 2.269448 & -2.353835 & 0.755572
\end{tabular}




\begin{tabular}{|c|c|c|c|c|c|}
\hline 13 & 7 & 0 & 3.613120 & -2.129905 & -1.552410 \\
\hline 14 & 7 & 0 & 4.215454 & -0.369934 & 0.943055 \\
\hline 15 & 6 & 0 & -3.921107 & 0.425175 & -2.121610 \\
\hline 16 & 6 & 0 & -5.217952 & 0.463786 & -2.691778 \\
\hline 17 & 6 & 0 & -6.252142 & -0.269521 & -2.144947 \\
\hline 18 & 6 & 0 & -6.019642 & -1.073549 & -1.000948 \\
\hline 19 & 6 & 0 & -7.007124 & -1.880943 & -0.342107 \\
\hline 20 & 6 & 0 & -6.684335 & -2.637897 & 0.751399 \\
\hline 21 & 6 & 0 & -5.346304 & -2.654242 & 1.270912 \\
\hline 22 & 6 & 0 & -4.907455 & -3.426207 & 2.375211 \\
\hline 23 & 6 & 0 & -3.582324 & -3.382230 & 2.758947 \\
\hline 24 & 6 & 0 & -2.649517 & -2.571102 & 2.064806 \\
\hline 25 & 6 & 0 & -4.707709 & -1.067021 & -0.488646 \\
\hline 26 & 6 & 0 & -4.368836 & -1.862883 & 0.636228 \\
\hline 27 & 6 & 0 & -2.765470 & 1.182325 & -2.709943 \\
\hline 28 & 6 & 0 & -1.801353 & 1.757077 & -1.665992 \\
\hline 29 & 6 & 0 & -2.441821 & 2.766765 & -0.691916 \\
\hline 30 & 6 & 0 & -1.044859 & 4.434387 & 0.507691 \\
\hline 31 & 6 & 0 & -0.053419 & 4.668486 & -0.608359 \\
\hline 32 & 6 & 0 & 0.065865 & 5.887311 & -1.268365 \\
\hline 33 & 6 & 0 & 1.038242 & 6.025082 & -2.261855 \\
\hline 34 & 6 & 0 & 1.850845 & 4.933907 & -2.568979 \\
\hline 35 & 6 & 0 & 1.666185 & 3.744963 & -1.869440 \\
\hline 36 & 6 & 0 & -2.094598 & 2.583237 & 1.759846 \\
\hline 37 & 6 & 0 & -1.010925 & 2.408910 & 2.800877 \\
\hline 38 & 6 & 0 & -1.220227 & 2.600093 & 4.164249 \\
\hline 39 & 6 & 0 & -0.166171 & 2.351935 & 5.046881 \\
\hline 40 & 6 & 0 & 1.064168 & 1.928438 & 4.539624 \\
\hline 41 & 6 & 0 & 1.200812 & 1.771850 & 3.163422 \\
\hline 42 & 6 & 0 & -1.196856 & -2.532306 & 2.472765 \\
\hline 43 & 6 & 0 & -0.264244 & -2.124628 & 1.317776 \\
\hline 44 & 6 & 0 & 1.201366 & -2.221953 & 1.789180 \\
\hline 45 & 6 & 0 & 2.023854 & -3.418732 & -0.255909 \\
\hline 46 & 6 & 0 & 3.098751 & -3.353773 & -1.318002 \\
\hline 47 & 6 & 0 & 3.533339 & -4.456922 & -2.044391 \\
\hline 48 & 6 & 0 & 4.498645 & -4.272857 & -3.038766 \\
\hline 49 & 6 & 0 & 5.009628 & -2.995841 & -3.272855 \\
\hline 50 & 6 & 0 & 4.537924 & -1.935550 & -2.502739 \\
\hline 51 & 6 & 0 & 3.558866 & -2.629095 & 1.468810 \\
\hline 52 & 6 & 0 & 4.302866 & -1.373062 & 1.833137 \\
\hline 53 & 6 & 0 & 5.111994 & -1.278489 & 2.964789 \\
\hline 54 & 6 & 0 & 5.863322 & -0.119495 & 3.161541 \\
\hline 55 & 6 & 0 & 5.773072 & 0.914674 & 2.227369 \\
\hline 56 & 6 & 0 & 4.927412 & 0.751103 & 1.135165 \\
\hline
\end{tabular}




\begin{tabular}{|c|c|c|c|c|c|}
\hline 57 & 1 & 0 & -5.380228 & 1.077252 & -3.571085 \\
\hline 58 & 1 & 0 & -7.242957 & -0.234850 & -2.588595 \\
\hline 59 & 1 & 0 & -8.020521 & -1.882921 & -0.730725 \\
\hline 60 & 1 & 0 & -7.438633 & -3.248072 & 1.237925 \\
\hline 61 & 1 & 0 & -5.612569 & -4.057505 & 2.908008 \\
\hline 62 & 1 & 0 & -3.231678 & -3.976538 & 3.595842 \\
\hline 63 & 1 & 0 & -3.138284 & 1.981039 & -3.357382 \\
\hline 64 & 1 & 0 & -2.174052 & 0.496876 & -3.332483 \\
\hline 65 & 1 & 0 & -1.016014 & 2.264435 & -2.242986 \\
\hline 66 & 1 & 0 & -2.669062 & 3.703118 & -1.208631 \\
\hline 67 & 1 & 0 & -3.385136 & 2.371394 & -0.304668 \\
\hline 68 & 1 & 0 & -0.541910 & 4.586136 & 1.468752 \\
\hline 69 & 1 & 0 & -1.881815 & 5.140695 & 0.457752 \\
\hline 70 & 1 & 0 & -0.588950 & 6.713168 & -1.010093 \\
\hline 71 & 1 & 0 & 1.151494 & 6.965827 & -2.791105 \\
\hline 72 & 1 & 0 & 2.609071 & 4.993741 & -3.341694 \\
\hline 73 & 1 & 0 & 2.254256 & 2.863656 & -2.084003 \\
\hline 74 & 1 & 0 & -2.554006 & 1.604118 & 1.585055 \\
\hline 75 & 1 & 0 & -2.879953 & 3.265484 & 2.108644 \\
\hline 76 & 1 & 0 & -2.183137 & 2.944377 & 4.527318 \\
\hline 77 & 1 & 0 & -0.301004 & 2.500056 & 6.113679 \\
\hline 78 & 1 & 0 & 1.907027 & 1.740307 & 5.195343 \\
\hline 79 & 1 & 0 & 2.130334 & 1.465406 & 2.694931 \\
\hline 80 & 1 & 0 & -0.931379 & -3.517315 & 2.869831 \\
\hline 81 & 1 & 0 & -1.084577 & -1.812505 & 3.295409 \\
\hline 82 & 1 & 0 & -0.419451 & -2.817999 & 0.482412 \\
\hline 83 & 1 & 0 & 1.439489 & -1.335544 & 2.384854 \\
\hline 84 & 1 & 0 & 1.267852 & -3.098875 & 2.447889 \\
\hline 85 & 1 & 0 & 1.064729 & -3.218151 & -0.736469 \\
\hline 86 & 1 & 0 & 1.992613 & -4.411130 & 0.212738 \\
\hline 87 & 1 & 0 & 3.124060 & -5.440256 & -1.837597 \\
\hline 88 & 1 & 0 & 4.848605 & -5.119608 & -3.620576 \\
\hline 89 & 1 & 0 & 5.759041 & -2.817088 & -4.035537 \\
\hline 90 & 1 & 0 & 4.865803 & -0.910411 & -2.633290 \\
\hline 91 & 1 & 0 & 4.201424 & -3.206783 & 0.799487 \\
\hline 92 & 1 & 0 & 3.383700 & -3.252670 & 2.352346 \\
\hline 93 & 1 & 0 & 5.162746 & -2.103905 & 3.667467 \\
\hline 94 & 1 & 0 & 6.510843 & -0.025966 & 4.027618 \\
\hline 95 & 1 & 0 & 6.345686 & 1.828771 & 2.337777 \\
\hline 96 & 1 & 0 & 4.814536 & 1.529538 & 0.390795 \\
\hline 97 & 8 & 0 & 1.142051 & -1.090618 & -1.673726 \\
\hline 98 & 6 & 0 & 0.612081 & -0.462545 & -2.682671 \\
\hline 99 & 8 & 0 & 1.148422 & 0.669656 & -3.111787 \\
\hline 100 & 8 & 0 & -0.404184 & -0.922683 & -3.232669 \\
\hline
\end{tabular}




$\begin{array}{lllrrl}101 & 8 & 0 & -1.567276 & -2.436326 & -1.478582 \\ 102 & 1 & 0 & -2.283753 & -2.936239 & -1.888917 \\ 103 & 1 & 0 & -1.078131 & -1.978631 & -2.230476 \\ 104 & 8 & 0 & 3.353752 & 0.745626 & -1.768242 \\ 105 & 1 & 0 & 3.645880 & 1.522997 & -1.273371 \\ 106 & 1 & 0 & 2.033678 & 0.808579 & -2.653666\end{array}$

\section{Int1"}

\begin{tabular}{|c|c|c|c|c|c|}
\hline \multirow{2}{*}{$\begin{array}{l}\text { Center } \\
\text { Number }\end{array}$} & \multirow{2}{*}{$\begin{array}{l}\text { Atomic } \\
\text { Number }\end{array}$} & \multirow{2}{*}{$\begin{array}{l}\text { Atomic } \\
\text { Type }\end{array}$} & \multicolumn{3}{|c|}{ Coordinates (Angstroms) } \\
\hline & & & $\mathrm{X}$ & $\mathrm{Y}$ & $\mathrm{Z}$ \\
\hline 1 & 29 & 0 & -1.969117 & -0.708843 & -0.165754 \\
\hline 2 & 29 & 0 & 0.367906 & 2.073390 & 0.383853 \\
\hline 3 & 29 & 0 & 2.682121 & -0.490597 & -0.629077 \\
\hline 4 & 8 & 0 & -1.112038 & 0.868095 & -0.723944 \\
\hline 5 & 8 & 0 & -0.436355 & -1.057918 & 0.776496 \\
\hline 6 & 8 & 0 & 2.152281 & 1.389561 & 0.011782 \\
\hline 7 & 7 & 0 & -3.698837 & -0.254086 & -0.968535 \\
\hline 8 & 7 & 0 & -3.020248 & -2.056258 & 0.841742 \\
\hline 9 & 7 & 0 & -1.476252 & 2.835264 & 1.022238 \\
\hline 10 & 7 & 0 & 0.416297 & 4.040989 & -0.449470 \\
\hline 11 & 7 & 0 & 0.463829 & 1.433417 & 2.322885 \\
\hline 12 & 7 & 0 & 2.268562 & -2.526132 & 0.438373 \\
\hline 13 & 7 & 0 & 3.640631 & -1.870682 & -1.844715 \\
\hline 14 & 7 & 0 & 4.162500 & -0.481128 & 0.765457 \\
\hline 15 & 6 & 0 & -3.952738 & 0.657806 & -1.907427 \\
\hline 16 & 6 & 0 & -5.256706 & 0.765873 & -2.451930 \\
\hline 17 & 6 & 0 & -6.269745 & -0.068258 & -2.027012 \\
\hline 18 & 6 & 0 & -6.006631 & -1.041270 & -1.031422 \\
\hline 19 & 6 & 0 & -6.977245 & -1.953675 & -0.497987 \\
\hline 20 & 6 & 0 & -6.635861 & -2.859281 & 0.468715 \\
\hline 21 & 6 & 0 & -5.294506 & -2.929928 & 0.972890 \\
\hline 22 & 6 & 0 & -4.845801 & -3.839209 & 1.961625 \\
\hline 23 & 6 & 0 & -3.522704 & -3.824773 & 2.351958 \\
\hline 24 & 6 & 0 & -2.604212 & -2.915395 & 1.771078 \\
\hline 25 & 6 & 0 & -4.687430 & -1.095170 & -0.538583 \\
\hline 26 & 6 & 0 & -4.328800 & -2.045825 & 0.450018 \\
\hline 27 & 6 & 0 & -2.829112 & 1.531010 & -2.372327 \\
\hline 28 & 6 & 0 & -1.851823 & 1.937002 & -1.266301 \\
\hline 29 & 6 & 0 & -2.458615 & 2.767886 & -0.113974 \\
\hline 30 & 6 & 0 & -1.125262 & 4.224937 & 1.411596 \\
\hline
\end{tabular}




\begin{tabular}{|c|c|c|c|c|c|}
\hline 31 & 6 & 0 & -0.367190 & 4.874237 & 0.276402 \\
\hline 32 & 6 & 0 & -0.484603 & 6.227943 & -0.023210 \\
\hline 33 & 6 & 0 & 0.220092 & 6.744800 & -1.112170 \\
\hline 34 & 6 & 0 & 0.995424 & 5.879476 & -1.884077 \\
\hline 35 & 6 & 0 & 1.063318 & 4.537316 & -1.523112 \\
\hline 36 & 6 & 0 & -1.885903 & 2.009561 & 2.184863 \\
\hline 37 & 6 & 0 & -0.697822 & 1.537506 & 2.993474 \\
\hline 38 & 6 & 0 & -0.802794 & 1.156346 & 4.329895 \\
\hline 39 & 6 & 0 & 0.322853 & 0.637343 & 4.972255 \\
\hline 40 & 6 & 0 & 1.521402 & 0.524251 & 4.262777 \\
\hline 41 & 6 & 0 & 1.553219 & 0.943173 & 2.937158 \\
\hline 42 & 6 & 0 & -1.156221 & -2.902329 & 2.178526 \\
\hline 43 & 6 & 0 & -0.236340 & -2.417986 & 1.045780 \\
\hline 44 & 6 & 0 & 1.227060 & -2.650380 & 1.475807 \\
\hline 45 & 6 & 0 & 2.029460 & -3.354388 & -0.766434 \\
\hline 46 & 6 & 0 & 3.105464 & -3.107642 & -1.806769 \\
\hline 47 & 6 & 0 & 3.516530 & -4.095653 & -2.698447 \\
\hline 48 & 6 & 0 & 4.482876 & -3.787881 & -3.657609 \\
\hline 49 & 6 & 0 & 5.027815 & -2.503440 & -3.688821 \\
\hline 50 & 6 & 0 & 4.579074 & -1.571801 & -2.758482 \\
\hline 51 & 6 & 0 & 3.580071 & -2.834520 & 1.061228 \\
\hline 52 & 6 & 0 & 4.339242 & -1.601493 & 1.494105 \\
\hline 53 & 6 & 0 & 5.261922 & -1.644226 & 2.540576 \\
\hline 54 & 6 & 0 & 6.038591 & -0.519887 & 2.815418 \\
\hline 55 & 6 & 0 & 5.869376 & 0.626746 & 2.035324 \\
\hline 56 & 6 & 0 & 4.915849 & 0.605938 & 1.025753 \\
\hline 57 & 1 & 0 & -5.439288 & 1.514724 & -3.214576 \\
\hline 58 & 1 & 0 & -7.266753 & 0.017989 & -2.449150 \\
\hline 59 & 1 & 0 & -7.993672 & -1.910598 & -0.876118 \\
\hline 60 & 1 & 0 & -7.377518 & -3.545107 & 0.865621 \\
\hline 61 & 1 & 0 & -5.542111 & -4.546748 & 2.402205 \\
\hline 62 & 1 & 0 & -3.161741 & -4.517186 & 3.104667 \\
\hline 63 & 1 & 0 & -3.230643 & 2.421769 & -2.863933 \\
\hline 64 & 1 & 0 & -2.232328 & 0.980392 & -3.113540 \\
\hline 65 & 1 & 0 & -1.105580 & 2.552903 & -1.786777 \\
\hline 66 & 1 & 0 & -2.697177 & 3.778156 & -0.455024 \\
\hline 67 & 1 & 0 & -3.386967 & 2.315590 & 0.247274 \\
\hline 68 & 1 & 0 & -0.492112 & 4.169780 & 2.304574 \\
\hline 69 & 1 & 0 & -2.018971 & 4.804251 & 1.672986 \\
\hline 70 & 1 & 0 & -1.123661 & 6.864216 & 0.580362 \\
\hline 71 & 1 & 0 & 0.146614 & 7.797885 & -1.364351 \\
\hline 72 & 1 & 0 & 1.533304 & 6.229597 & -2.758086 \\
\hline 73 & 1 & 0 & 1.628288 & 3.827166 & -2.111424 \\
\hline 74 & 1 & 0 & -2.384240 & 1.119631 & 1.791118 \\
\hline
\end{tabular}




\begin{tabular}{|c|c|c|c|c|c|}
\hline 75 & 1 & 0 & -2.610823 & 2.542964 & 2.812515 \\
\hline 76 & 1 & 0 & -1.743811 & 1.270588 & 4.858357 \\
\hline 77 & 1 & 0 & 0.268283 & 0.339333 & 6.014625 \\
\hline 78 & 1 & 0 & 2.419956 & 0.138366 & 4.731256 \\
\hline 79 & 1 & 0 & 2.449372 & 0.898701 & 2.329865 \\
\hline 80 & 1 & 0 & -0.885151 & -3.908570 & 2.511456 \\
\hline 81 & 1 & 0 & -1.036192 & -2.232451 & 3.041384 \\
\hline 82 & 1 & 0 & -0.434858 & -3.013364 & 0.145034 \\
\hline 83 & 1 & 0 & 1.470766 & -1.940604 & 2.273569 \\
\hline 84 & 1 & 0 & 1.263902 & -3.663744 & 1.907206 \\
\hline 85 & 1 & 0 & 1.075197 & -3.044104 & -1.201232 \\
\hline 86 & 1 & 0 & 1.979952 & -4.426916 & -0.527932 \\
\hline 87 & 1 & 0 & 3.086549 & -5.090247 & -2.640854 \\
\hline 88 & 1 & 0 & 4.812074 & -4.543072 & -4.364138 \\
\hline 89 & 1 & 0 & 5.786404 & -2.227121 & -4.412358 \\
\hline 90 & 1 & 0 & 4.969757 & -0.559579 & -2.732128 \\
\hline 91 & 1 & 0 & 4.207264 & -3.350527 & 0.328164 \\
\hline 92 & 1 & 0 & 3.473094 & -3.525177 & 1.906881 \\
\hline 93 & 1 & 0 & 5.378466 & -2.555721 & 3.118052 \\
\hline 94 & 1 & 0 & 6.768914 & -0.539572 & 3.618209 \\
\hline 95 & 1 & 0 & 6.464390 & 1.517605 & 2.202265 \\
\hline 96 & 1 & 0 & 4.734356 & 1.462975 & 0.390478 \\
\hline 97 & 8 & 0 & 1.240434 & -0.652561 & -1.891617 \\
\hline 98 & 6 & 0 & 0.566047 & 0.083871 & -2.697754 \\
\hline 99 & 8 & 0 & 0.941189 & 1.375298 & -2.884350 \\
\hline 100 & 8 & 0 & -0.429643 & -0.316214 & -3.320280 \\
\hline 101 & 8 & 0 & -1.464802 & -2.158869 & -1.817892 \\
\hline 102 & 1 & 0 & -2.157857 & -2.618550 & -2.307904 \\
\hline 103 & 1 & 0 & -1.005708 & -1.556271 & -2.486888 \\
\hline 104 & 8 & 0 & 2.893413 & 2.149819 & -0.991950 \\
\hline 105 & 1 & 0 & 3.115657 & 2.966758 & -0.515173 \\
\hline 106 & 1 & 0 & 1.751276 & 1.560309 & -2.380218 \\
\hline
\end{tabular}

TS2

\begin{tabular}{cccccc} 
Center & Atomic & Atomic & \multicolumn{3}{c}{ Coordinates (Angstroms) } \\
Number & Number & Type & X & Y & Z \\
- \hdashline---1.419513 & -0.948926 & -0.286736 \\
1 & 29 & 0 & -0.003466 & 2.250819 & -0.175733 \\
2 & 29 & 0 & -144809 & -1.174611 & -0.260604 \\
3 & 29 & 0 & -0.884798 & 0.779248 & -1.124168
\end{tabular}




\begin{tabular}{|c|c|c|c|c|c|}
\hline 5 & 8 & 0 & 0.334224 & -1.248282 & 0.677020 \\
\hline 6 & 8 & 0 & 1.725136 & 1.269682 & -0.665246 \\
\hline 7 & 7 & 0 & -3.226662 & -0.886719 & -1.254302 \\
\hline 8 & 7 & 0 & -2.546481 & -2.060160 & 1.035334 \\
\hline 9 & 7 & 0 & -1.744310 & 3.348326 & -0.571317 \\
\hline 10 & 7 & 0 & 0.782930 & 4.097891 & -0.060554 \\
\hline 11 & 7 & 0 & -0.962430 & 2.020395 & 1.758102 \\
\hline 12 & 7 & 0 & 2.732420 & -2.678387 & 1.041052 \\
\hline 13 & 7 & 0 & 3.582573 & -2.133771 & -1.382890 \\
\hline 14 & 7 & 0 & 3.699480 & -0.068296 & 1.121009 \\
\hline 15 & 6 & 0 & -3.499829 & -0.286663 & -2.415771 \\
\hline 16 & 6 & 0 & -4.788640 & -0.376738 & -2.988016 \\
\hline 17 & 6 & 0 & -5.785389 & -1.088388 & -2.348640 \\
\hline 18 & 6 & 0 & -5.511493 & -1.722806 & -1.114426 \\
\hline 19 & 6 & 0 & -6.473573 & -2.474991 & -0.360187 \\
\hline 20 & 6 & 0 & -6.132970 & -3.054426 & 0.828852 \\
\hline 21 & 6 & 0 & -4.802267 & -2.934573 & 1.354138 \\
\hline 22 & 6 & 0 & -4.374262 & -3.510425 & 2.573483 \\
\hline 23 & 6 & 0 & -3.065559 & -3.348012 & 2.980421 \\
\hline 24 & 6 & 0 & -2.157868 & -2.614556 & 2.182267 \\
\hline 25 & 6 & 0 & -4.197514 & -1.589695 & -0.612380 \\
\hline 26 & 6 & 0 & -3.836464 & -2.207625 & 0.624102 \\
\hline 27 & 6 & 0 & -2.388593 & 0.488223 & -3.064295 \\
\hline 28 & 6 & 0 & -1.666347 & 1.452946 & -2.114055 \\
\hline 29 & 6 & 0 & -2.591859 & 2.433408 & -1.387464 \\
\hline 30 & 6 & 0 & -1.240951 & 4.526532 & -1.323719 \\
\hline 31 & 6 & 0 & 0.026621 & 5.037936 & -0.674108 \\
\hline 32 & 6 & 0 & 0.417991 & 6.372444 & -0.711314 \\
\hline 33 & 6 & 0 & 1.621277 & 6.741707 & -0.106687 \\
\hline 34 & 6 & 0 & 2.389392 & 5.767536 & 0.533899 \\
\hline 35 & 6 & 0 & 1.932466 & 4.454796 & 0.537839 \\
\hline 36 & 6 & 0 & -2.360046 & 3.734666 & 0.722182 \\
\hline 37 & 6 & 0 & -2.111700 & 2.718858 & 1.823593 \\
\hline 38 & 6 & 0 & -2.985779 & 2.597633 & 2.904007 \\
\hline 39 & 6 & 0 & -2.635119 & 1.759458 & 3.963274 \\
\hline 40 & 6 & 0 & -1.429728 & 1.057170 & 3.902128 \\
\hline 41 & 6 & 0 & -0.630226 & 1.205700 & 2.772118 \\
\hline 42 & 6 & 0 & -0.725382 & -2.430895 & 2.587867 \\
\hline 43 & 6 & 0 & 0.281639 & -2.472837 & 1.423224 \\
\hline 44 & 6 & 0 & 1.650294 & -2.756933 & 2.041188 \\
\hline 45 & 6 & 0 & 2.831765 & -3.849525 & 0.128490 \\
\hline 46 & 6 & 0 & 3.682344 & -3.440313 & -1.055338 \\
\hline 47 & 6 & 0 & 4.512571 & -4.306389 & -1.758711 \\
\hline 48 & 6 & 0 & 5.255153 & -3.801747 & -2.829455 \\
\hline
\end{tabular}




\begin{tabular}{|c|c|c|c|c|c|}
\hline 49 & 6 & 0 & 5.153027 & -2.447837 & -3.155440 \\
\hline 50 & 6 & 0 & 4.299433 & -1.643857 & -2.406569 \\
\hline 51 & 6 & 0 & 4.039206 & -2.405984 & 1.694028 \\
\hline 52 & 6 & 0 & 4.258382 & -0.937325 & 1.981714 \\
\hline 53 & 6 & 0 & 5.096613 & -0.534327 & 3.022692 \\
\hline 54 & 6 & 0 & 5.402201 & 0.819457 & 3.155140 \\
\hline 55 & 6 & 0 & 4.860691 & 1.720639 & 2.237153 \\
\hline 56 & 6 & 0 & 4.012744 & 1.233318 & 1.246235 \\
\hline 57 & 1 & 0 & -4.982320 & 0.117173 & -3.933907 \\
\hline 58 & 1 & 0 & -6.777300 & -1.161179 & -2.785128 \\
\hline 59 & 1 & 0 & -7.480482 & -2.574526 & -0.752981 \\
\hline 60 & 1 & 0 & -6.866008 & -3.620640 & 1.394687 \\
\hline 61 & 1 & 0 & -5.073595 & -4.082327 & 3.176368 \\
\hline 62 & 1 & 0 & -2.717180 & -3.790227 & 3.907500 \\
\hline 63 & 1 & 0 & -2.773777 & 1.051107 & -3.918922 \\
\hline 64 & 1 & 0 & -1.632399 & -0.197830 & -3.461136 \\
\hline 65 & 1 & 0 & -0.971978 & 2.017890 & -2.752749 \\
\hline 66 & 1 & 0 & -3.233652 & 3.003362 & -2.070742 \\
\hline 67 & 1 & 0 & -3.226515 & 1.870762 & -0.699160 \\
\hline 68 & 1 & 0 & -2.001772 & 5.313662 & -1.390812 \\
\hline 69 & 1 & 0 & -1.013687 & 4.203999 & -2.345035 \\
\hline 70 & 1 & 0 & -0.207860 & 7.109075 & -1.204177 \\
\hline 71 & 1 & 0 & 1.947983 & 7.776486 & -0.126555 \\
\hline 72 & 1 & 0 & 3.321952 & 6.019812 & 1.025722 \\
\hline 73 & 1 & 0 & 2.476649 & 3.658001 & 1.029775 \\
\hline 74 & 1 & 0 & -3.432405 & 3.923343 & 0.596822 \\
\hline 75 & 1 & 0 & -1.905420 & 4.678733 & 1.040370 \\
\hline 76 & 1 & 0 & -3.910733 & 3.165123 & 2.925992 \\
\hline 77 & 1 & 0 & -3.287952 & 1.664571 & 4.825238 \\
\hline 78 & 1 & 0 & -1.115360 & 0.411712 & 4.715254 \\
\hline 79 & 1 & 0 & 0.297376 & 0.658014 & 2.643657 \\
\hline 80 & 1 & 0 & -0.471440 & -3.204326 & 3.319381 \\
\hline 81 & 1 & 0 & -0.616450 & -1.468640 & 3.098314 \\
\hline 82 & 1 & 0 & 0.001787 & -3.288230 & 0.741503 \\
\hline 83 & 1 & 0 & 1.858392 & -1.984549 & 2.787721 \\
\hline 84 & 1 & 0 & 1.663872 & -3.733193 & 2.543901 \\
\hline 85 & 1 & 0 & 1.823246 & -4.108414 & -0.209318 \\
\hline 86 & 1 & 0 & 3.248935 & -4.722811 & 0.644828 \\
\hline 87 & 1 & 0 & 4.582422 & -5.350451 & -1.471814 \\
\hline 88 & 1 & 0 & 5.912145 & -4.455422 & -3.394246 \\
\hline 89 & 1 & 0 & 5.722747 & -2.019702 & -3.972455 \\
\hline 90 & 1 & 0 & 4.173658 & -0.587536 & -2.617363 \\
\hline 91 & 1 & 0 & 4.832788 & -2.733115 & 1.016170 \\
\hline 92 & 1 & 0 & 4.129957 & -3.007212 & 2.606558 \\
\hline
\end{tabular}




$\begin{array}{rrrrrr}93 & 1 & 0 & 5.515733 & -1.268883 & 3.703157 \\ 94 & 1 & 0 & 6.059152 & 1.160443 & 3.948886 \\ 95 & 1 & 0 & 5.096357 & 2.778380 & 2.283655 \\ 96 & 1 & 0 & 3.572699 & 1.890658 & 0.506649 \\ 97 & 8 & 0 & 1.368674 & -0.833073 & -2.243355 \\ 98 & 6 & 0 & 1.213891 & 0.194169 & -2.895484 \\ 99 & 8 & 0 & 1.805194 & 1.544670 & -1.952345 \\ 100 & 8 & 0 & 0.798633 & 0.653742 & -3.907271 \\ 101 & 8 & 0 & -0.631125 & -2.610383 & -1.673539 \\ 102 & 1 & 0 & -1.179189 & -3.055847 & -2.332165 \\ 103 & 1 & 0 & 0.079517 & -2.146618 & -2.155967\end{array}$

\section{Int2}

\begin{tabular}{|c|c|c|c|c|c|}
\hline \multirow{2}{*}{$\begin{array}{l}\text { Center } \\
\text { Number }\end{array}$} & \multirow{2}{*}{$\begin{array}{l}\text { Atomic } \\
\text { Number }\end{array}$} & \multirow{2}{*}{$\begin{array}{l}\text { Atomic } \\
\text { Type }\end{array}$} & \multicolumn{3}{|c|}{ Coordinates (Angstroms) } \\
\hline & & & $\mathrm{X}$ & $\mathrm{Y}$ & $\mathrm{Z}$ \\
\hline 1 & 29 & 0 & 1.167101 & -0.749510 & 0.530397 \\
\hline 2 & 29 & 0 & 0.122122 & 2.288365 & -1.118743 \\
\hline 3 & 29 & 0 & -2.529132 & -0.706144 & 0.154650 \\
\hline 4 & 8 & 0 & 0.637922 & 1.116149 & 0.674317 \\
\hline 5 & 8 & 0 & -0.557007 & -1.479627 & -0.048620 \\
\hline 6 & 8 & 0 & -1.518518 & 1.237217 & -1.408400 \\
\hline 7 & 7 & 0 & 2.916771 & -0.453873 & 1.520199 \\
\hline 8 & 7 & 0 & 2.187169 & -2.440824 & -0.086850 \\
\hline 9 & 7 & 0 & 1.927326 & 3.266215 & -0.823787 \\
\hline 10 & 7 & 0 & -0.673603 & 3.997447 & -0.419991 \\
\hline 11 & 7 & 0 & 1.225665 & 1.131444 & -2.351173 \\
\hline 12 & 7 & 0 & -2.979443 & -2.637312 & 0.626790 \\
\hline 13 & 7 & 0 & -3.026252 & -0.388602 & 2.146473 \\
\hline 14 & 7 & 0 & -3.903751 & -1.055445 & -1.360549 \\
\hline 15 & 6 & 0 & 3.193321 & 0.534399 & 2.375182 \\
\hline 16 & 6 & 0 & 4.479172 & 0.643506 & 2.950060 \\
\hline 17 & 6 & 0 & 5.467961 & -0.265264 & 2.621530 \\
\hline 18 & 6 & 0 & 5.187170 & -1.312463 & 1.711796 \\
\hline 19 & 6 & 0 & 6.135635 & -2.307183 & 1.296030 \\
\hline 20 & 6 & 0 & 5.776305 & -3.299826 & 0.428335 \\
\hline 21 & 6 & 0 & 4.436300 & -3.387148 & -0.080903 \\
\hline 22 & 6 & 0 & 3.972295 & -4.410037 & -0.942391 \\
\hline 23 & 6 & 0 & 2.643627 & -4.435865 & -1.317794 \\
\hline 24 & 6 & 0 & 1.751662 & -3.439535 & -0.857484 \\
\hline 25 & 6 & 0 & 3.873724 & -1.363496 & 1.196983 \\
\hline
\end{tabular}




\begin{tabular}{|c|c|c|c|c|c|}
\hline 26 & 6 & 0 & 3.489749 & -2.415614 & 0.308670 \\
\hline 27 & 6 & 0 & 2.091890 & 1.523595 & 2.638360 \\
\hline 28 & 6 & 0 & 1.447162 & 2.059243 & 1.340784 \\
\hline 29 & 6 & 0 & 2.524535 & 2.592310 & 0.373444 \\
\hline 30 & 6 & 0 & 1.651022 & 4.712863 & -0.603516 \\
\hline 31 & 6 & 0 & 0.228296 & 4.966554 & -0.154381 \\
\hline 32 & 6 & 0 & -0.149713 & 6.177215 & 0.421442 \\
\hline 33 & 6 & 0 & -1.496646 & 6.399764 & 0.705611 \\
\hline 34 & 6 & 0 & -2.427295 & 5.400797 & 0.410084 \\
\hline 35 & 6 & 0 & -1.976360 & 4.210267 & -0.144940 \\
\hline 36 & 6 & 0 & 2.728709 & 3.006785 & -2.052937 \\
\hline 37 & 6 & 0 & 2.473502 & 1.605027 & -2.561665 \\
\hline 38 & 6 & 0 & 3.425002 & 0.857957 & -3.250123 \\
\hline 39 & 6 & 0 & 3.065321 & -0.397023 & -3.747475 \\
\hline 40 & 6 & 0 & 1.772913 & -0.875208 & -3.523942 \\
\hline 41 & 6 & 0 & 0.878596 & -0.083488 & -2.810099 \\
\hline 42 & 6 & 0 & 0.278236 & -3.495705 & -1.161904 \\
\hline 43 & 6 & 0 & -0.580903 & -2.899547 & -0.033050 \\
\hline 44 & 6 & 0 & -2.020919 & -3.423437 & -0.187000 \\
\hline 45 & 6 & 0 & -2.820374 & -2.803234 & 2.094082 \\
\hline 46 & 6 & 0 & -3.231513 & -1.538895 & 2.822269 \\
\hline 47 & 6 & 0 & -3.732461 & -1.543105 & 4.121186 \\
\hline 48 & 6 & 0 & -4.014305 & -0.321956 & 4.737765 \\
\hline 49 & 6 & 0 & -3.788808 & 0.864699 & 4.037252 \\
\hline 50 & 6 & 0 & -3.297252 & 0.786956 & 2.737874 \\
\hline 51 & 6 & 0 & -4.387613 & -2.847293 & 0.196894 \\
\hline 52 & 6 & 0 & -4.657913 & -2.149287 & -1.118224 \\
\hline 53 & 6 & 0 & -5.646088 & -2.568191 & -2.004033 \\
\hline 54 & 6 & 0 & -5.869475 & -1.823629 & -3.163994 \\
\hline 55 & 6 & 0 & -5.089103 & -0.691939 & -3.407881 \\
\hline 56 & 6 & 0 & -4.111453 & -0.342766 & -2.481691 \\
\hline 57 & 1 & 0 & 4.679474 & 1.448350 & 3.648777 \\
\hline 58 & 1 & 0 & 6.459099 & -0.181149 & 3.057869 \\
\hline 59 & 1 & 0 & 7.146135 & -2.260105 & 1.689475 \\
\hline 60 & 1 & 0 & 6.498399 & -4.050658 & 0.123383 \\
\hline 61 & 1 & 0 & 4.655877 & -5.183383 & -1.280692 \\
\hline 62 & 1 & 0 & 2.264060 & -5.234162 & -1.946680 \\
\hline 63 & 1 & 0 & 2.474026 & 2.354328 & 3.238237 \\
\hline 64 & 1 & 0 & 1.295010 & 1.043059 & 3.218017 \\
\hline 65 & 1 & 0 & 0.803231 & 2.897598 & 1.647229 \\
\hline 66 & 1 & 0 & 3.223504 & 3.277516 & 0.868785 \\
\hline 67 & 1 & 0 & 3.090522 & 1.733614 & 0.006969 \\
\hline 68 & 1 & 0 & 1.797974 & 5.241572 & -1.550742 \\
\hline 69 & 1 & 0 & 2.364625 & 5.141904 & 0.108121 \\
\hline
\end{tabular}




\begin{tabular}{rrrrrr}
70 & 1 & 0 & 0.597250 & 6.936560 & 0.629588 \\
71 & 1 & 0 & -1.815173 & 7.339474 & 1.145522 \\
72 & 1 & 0 & -3.484732 & 5.540774 & 0.604015 \\
73 & 1 & 0 & -2.646090 & 3.394051 & -0.380047 \\
74 & 1 & 0 & 3.797021 & 3.179699 & -1.878246 \\
75 & 1 & 0 & 2.402844 & 3.711229 & -2.824880 \\
76 & 1 & 0 & 4.422059 & 1.256485 & -3.406087 \\
77 & 1 & 0 & 3.785069 & -0.989842 & -4.303080 \\
78 & 1 & 0 & 1.460717 & -1.842981 & -3.899815 \\
79 & 1 & 0 & -0.126360 & -0.404805 & -2.561863 \\
80 & 1 & 0 & 0.002018 & -4.538316 & -1.353137 \\
81 & 1 & 0 & 0.056407 & -2.934325 & -2.078531 \\
82 & 1 & 0 & -0.180282 & -3.269837 & 0.924479 \\
83 & 1 & 0 & -2.333502 & -3.312976 & -1.228991 \\
84 & 1 & 0 & -2.071468 & -4.489420 & 0.072152 \\
85 & 1 & 0 & -1.763140 & -2.988278 & 2.300520 \\
86 & 1 & 0 & -3.379491 & -3.674391 & 2.454783 \\
87 & 1 & 0 & -3.901534 & -2.481448 & 4.639405 \\
88 & 1 & 0 & -4.410495 & -0.298960 & 5.747979 \\
89 & 1 & 0 & -4.000761 & 1.829929 & 4.483225 \\
90 & 1 & 0 & -3.109986 & 1.670332 & 2.135902 \\
91 & 1 & 0 & -5.032525 & -2.409559 & 0.966950 \\
92 & 1 & 0 & -4.623225 & -3.916879 & 0.138111 \\
93 & 1 & 0 & -6.232120 & -3.455663 & -1.788466 \\
94 & 1 & 0 & -6.638392 & -2.125832 & -3.867852 \\
95 & 1 & 0 & -5.231471 & -0.091028 & -4.299025 \\
96 & 1 & 0 & -3.467506 & 0.518277 & -2.621234 \\
97 & 8 & 0 & -2.141190 & 1.142822 & -0.252543 \\
---------------------------------------------- & & \\
\hline 9 & & & & &
\end{tabular}

\section{Int3}

\begin{tabular}{cccccc} 
Center & Atomic & Atomic & \multicolumn{3}{c}{ Coordinates (Angstroms) } \\
Number & Number & Type & X & Y & Z \\
- \hdashline-1 & 29 & 0 & 0.734955 & -1.199013 & 0.150945 \\
2 & 29 & 0 & 0.990080 & 2.151904 & 0.148758 \\
3 & 29 & 0 & -2.806802 & -0.390237 & 0.233206 \\
4 & 8 & 0 & 0.743829 & 0.526391 & 1.144953 \\
5 & 8 & 0 & -0.975545 & -0.902573 & -0.721245 \\
6 & 8 & 0 & -1.981823 & 0.855848 & 1.903567 \\
7 & 7 & 0 & 2.169900 & -1.971804 & 1.300215 \\
8 & 7 & 0 & 1.385829 & -2.573739 & -1.153176
\end{tabular}




\begin{tabular}{|c|c|c|c|c|c|}
\hline 9 & 7 & 0 & 2.645541 & 2.563252 & 1.287277 \\
\hline 10 & 7 & 0 & 0.818734 & 4.105790 & 0.051121 \\
\hline 11 & 7 & 0 & 2.399662 & 1.552050 & -1.336280 \\
\hline 12 & 7 & 0 & -3.729347 & -1.245503 & -1.324969 \\
\hline 13 & 7 & 0 & -3.972773 & -1.601067 & 1.357678 \\
\hline 14 & 7 & 0 & -3.356520 & 1.371185 & -0.687475 \\
\hline 15 & 6 & 0 & 2.462521 & -1.645646 & 2.562173 \\
\hline 16 & 6 & 0 & 3.530148 & -2.283630 & 3.229201 \\
\hline 17 & 6 & 0 & 4.273625 & -3.258966 & 2.582037 \\
\hline 18 & 6 & 0 & 3.959048 & -3.621617 & 1.249196 \\
\hline 19 & 6 & 0 & 4.641995 & -4.625948 & 0.479503 \\
\hline 20 & 6 & 0 & 4.251674 & -4.921266 & -0.798466 \\
\hline 21 & 6 & 0 & 3.141756 & -4.242653 & -1.411494 \\
\hline 22 & 6 & 0 & 2.650725 & -4.495219 & -2.716606 \\
\hline 23 & 6 & 0 & 1.554076 & -3.794060 & -3.190182 \\
\hline 24 & 6 & 0 & 0.921022 & -2.826797 & -2.377731 \\
\hline 25 & 6 & 0 & 2.879362 & -2.935628 & 0.655491 \\
\hline 26 & 6 & 0 & 2.462862 & -3.253414 & -0.672039 \\
\hline 27 & 6 & 0 & 1.577803 & -0.605109 & 3.204816 \\
\hline 28 & 6 & 0 & 1.437507 & 0.702894 & 2.403378 \\
\hline 29 & 6 & 0 & 2.801540 & 1.355254 & 2.145589 \\
\hline 30 & 6 & 0 & 2.276665 & 3.822121 & 1.986285 \\
\hline 31 & 6 & 0 & 1.544245 & 4.732364 & 1.018209 \\
\hline 32 & 6 & 0 & 1.596100 & 6.119730 & 1.091981 \\
\hline 33 & 6 & 0 & 0.889561 & 6.878976 & 0.154671 \\
\hline 34 & 6 & 0 & 0.161236 & 6.227249 & -0.844768 \\
\hline 35 & 6 & 0 & 0.154544 & 4.838311 & -0.868156 \\
\hline 36 & 6 & 0 & 3.761500 & 2.745411 & 0.321294 \\
\hline 37 & 6 & 0 & 3.643761 & 1.839669 & -0.896700 \\
\hline 38 & 6 & 0 & 4.780407 & 1.408636 & -1.579566 \\
\hline 39 & 6 & 0 & 4.626553 & 0.681660 & -2.762022 \\
\hline 40 & 6 & 0 & 3.338013 & 0.399881 & -3.222039 \\
\hline 41 & 6 & 0 & 2.254554 & 0.849784 & -2.474898 \\
\hline 42 & 6 & 0 & -0.292616 & -2.050705 & -2.826344 \\
\hline 43 & 6 & 0 & -1.347126 & -1.863149 & -1.718006 \\
\hline 44 & 6 & 0 & -2.665571 & -1.404991 & -2.358154 \\
\hline 45 & 6 & 0 & -4.301064 & -2.543624 & -0.857277 \\
\hline 46 & 6 & 0 & -4.705050 & -2.453424 & 0.594241 \\
\hline 47 & 6 & 0 & -5.719777 & -3.233119 & 1.136973 \\
\hline 48 & 6 & 0 & -5.985868 & -3.146368 & 2.506141 \\
\hline 49 & 6 & 0 & -5.229715 & -2.272328 & 3.288939 \\
\hline 50 & 6 & 0 & -4.239670 & -1.511801 & 2.677049 \\
\hline 51 & 6 & 0 & -4.796487 & -0.280401 & -1.726322 \\
\hline 52 & 6 & 0 & -4.308713 & 1.146798 & -1.621127 \\
\hline
\end{tabular}




\begin{tabular}{|c|c|c|c|c|c|}
\hline 53 & 6 & 0 & -4.850808 & 2.182558 & -2.378893 \\
\hline 54 & 6 & 0 & -4.411965 & 3.487492 & -2.147791 \\
\hline 55 & 6 & 0 & -3.430141 & 3.714004 & -1.178370 \\
\hline 56 & 6 & 0 & -2.923145 & 2.627202 & -0.475529 \\
\hline 57 & 1 & 0 & 3.755657 & -2.013188 & 4.255231 \\
\hline 58 & 1 & 0 & 5.092414 & -3.752757 & 3.097872 \\
\hline 59 & 1 & 0 & 5.474353 & -5.154805 & 0.933213 \\
\hline 60 & 1 & 0 & 4.773282 & -5.685310 & -1.366418 \\
\hline 61 & 1 & 0 & 3.127903 & -5.247926 & -3.337943 \\
\hline 62 & 1 & 0 & 1.163900 & -3.992967 & -4.182728 \\
\hline 63 & 1 & 0 & 1.946265 & -0.364864 & 4.206209 \\
\hline 64 & 1 & 0 & 0.574761 & -1.028522 & 3.335545 \\
\hline 65 & 1 & 0 & 0.819552 & 1.377525 & 3.012558 \\
\hline 66 & 1 & 0 & 3.316156 & 1.607916 & 3.080448 \\
\hline 67 & 1 & 0 & 3.425198 & 0.652043 & 1.589192 \\
\hline 68 & 1 & 0 & 3.160213 & 4.318130 & 2.405066 \\
\hline 69 & 1 & 0 & 1.618647 & 3.566977 & 2.823457 \\
\hline 70 & 1 & 0 & 2.187090 & 6.601374 & 1.864421 \\
\hline 71 & 1 & 0 & 0.922186 & 7.963553 & 0.194337 \\
\hline 72 & 1 & 0 & -0.377868 & 6.785599 & -1.602266 \\
\hline 73 & 1 & 0 & -0.378594 & 4.280656 & -1.630749 \\
\hline 74 & 1 & 0 & 4.722900 & 2.594404 & 0.825329 \\
\hline 75 & 1 & 0 & 3.738191 & 3.783294 & -0.025671 \\
\hline 76 & 1 & 0 & 5.769012 & 1.654362 & -1.204439 \\
\hline 77 & 1 & 0 & 5.498278 & 0.351566 & -3.318517 \\
\hline 78 & 1 & 0 & 3.176346 & -0.146473 & -4.144798 \\
\hline 79 & 1 & 0 & 1.232572 & 0.662602 & -2.785173 \\
\hline 80 & 1 & 0 & -0.742474 & -2.567839 & -3.679166 \\
\hline 81 & 1 & 0 & 0.010593 & -1.059995 & -3.187016 \\
\hline 82 & 1 & 0 & -1.498615 & -2.840707 & -1.235505 \\
\hline 83 & 1 & 0 & -2.510095 & -0.428515 & -2.822949 \\
\hline 84 & 1 & 0 & -3.011759 & -2.107858 & -3.125235 \\
\hline 85 & 1 & 0 & -3.531891 & -3.312920 & -0.965319 \\
\hline 86 & 1 & 0 & -5.141651 & -2.835741 & -1.496125 \\
\hline 87 & 1 & 0 & -6.294008 & -3.898657 & 0.500347 \\
\hline 88 & 1 & 0 & -6.774728 & -3.745450 & 2.950485 \\
\hline 89 & 1 & 0 & -5.407518 & -2.169120 & 4.353702 \\
\hline 90 & 1 & 0 & -3.646049 & -0.810150 & 3.249897 \\
\hline 91 & 1 & 0 & -5.638225 & -0.417446 & -1.038602 \\
\hline 92 & 1 & 0 & -5.152698 & -0.515127 & -2.735946 \\
\hline 93 & 1 & 0 & -5.612659 & 1.975521 & -3.123662 \\
\hline 94 & 1 & 0 & -4.833732 & 4.313447 & -2.712166 \\
\hline 95 & 1 & 0 & -3.076997 & 4.715626 & -0.959738 \\
\hline 96 & 1 & 0 & -2.166971 & 2.749762 & 0.294801 \\
\hline
\end{tabular}




\section{5' $\mathrm{Cu}_{3}(\mathrm{III}, \mathrm{III}, \mathrm{III})-\mathrm{O}-\mathrm{OH}_{2}-\mathrm{CO}_{3} \quad$ charge: +4}

\begin{tabular}{|c|c|c|c|c|c|}
\hline \multirow{2}{*}{$\begin{array}{l}\text { Center } \\
\text { Number }\end{array}$} & \multirow{2}{*}{$\begin{array}{l}\text { Atomic } \\
\text { Number }\end{array}$} & \multirow{2}{*}{$\begin{array}{l}\text { Atomic } \\
\text { Type }\end{array}$} & \multicolumn{3}{|c|}{ Coordinates (Angstroms) } \\
\hline & & & $\mathrm{X}$ & $\mathrm{Y}$ & \\
\hline 1 & 29 & 0 & -2.060482 & -0.546165 & -0.179122 \\
\hline 2 & 29 & 0 & 0.461113 & 1.827473 & 0.347613 \\
\hline 3 & 29 & 0 & 2.532002 & -0.647971 & -0.585460 \\
\hline 4 & 8 & 0 & -1.007564 & 0.872946 & -0.851555 \\
\hline 5 & 8 & 0 & -0.594198 & -0.982173 & 0.820024 \\
\hline 6 & 8 & 0 & 2.047894 & 0.984843 & 0.079812 \\
\hline 7 & 7 & 0 & -3.696787 & 0.050993 & -1.058686 \\
\hline 8 & 7 & 0 & -3.231483 & -1.742330 & 0.828702 \\
\hline 9 & 7 & 0 & -1.132373 & 3.011344 & 0.729989 \\
\hline 10 & 7 & 0 & 1.097978 & 3.511033 & -0.592261 \\
\hline 11 & 7 & 0 & 0.398219 & 1.494767 & 2.325294 \\
\hline 12 & 7 & 0 & 2.078968 & -2.542138 & 0.761082 \\
\hline 13 & 7 & 0 & 3.453764 & -2.068479 & -1.565555 \\
\hline 14 & 7 & 0 & 4.039050 & -0.503525 & 0.602661 \\
\hline 15 & 6 & 0 & -3.835838 & 0.935010 & -2.050056 \\
\hline 16 & 6 & 0 & -5.115500 & 1.169850 & -2.608114 \\
\hline 17 & 6 & 0 & -6.222745 & 0.479499 & -2.152947 \\
\hline 18 & 6 & 0 & -6.079439 & -0.474803 & -1.115276 \\
\hline 19 & 6 & 0 & -7.148240 & -1.254851 & -0.559063 \\
\hline 20 & 6 & 0 & -6.912261 & -2.160802 & 0.439621 \\
\hline 21 & 6 & 0 & -5.589116 & -2.361242 & 0.958940 \\
\hline 22 & 6 & 0 & -5.245126 & -3.289832 & 1.972628 \\
\hline 23 & 6 & 0 & -3.929435 & -3.408912 & 2.373642 \\
\hline 24 & 6 & 0 & -2.912950 & -2.615070 & 1.786309 \\
\hline 25 & 6 & 0 & -4.777647 & -0.654789 & -0.603765 \\
\hline 26 & 6 & 0 & -4.531386 & -1.600714 & 0.420005 \\
\hline 27 & 6 & 0 & -2.609585 & 1.628325 & -2.575502 \\
\hline 28 & 6 & 0 & -1.572860 & 1.990781 & -1.510381 \\
\hline 29 & 6 & 0 & -2.070298 & 2.996401 & -0.452689 \\
\hline 30 & 6 & 0 & -0.525528 & 4.362123 & 0.961911 \\
\hline 31 & 6 & 0 & 0.479716 & 4.625149 & -0.127236 \\
\hline 32 & 6 & 0 & 0.816010 & 5.885854 & -0.603571 \\
\hline 33 & 6 & 0 & 1.821139 & 5.992360 & -1.571546 \\
\hline 34 & 6 & 0 & 2.456126 & 4.837194 & -2.031321 \\
\hline 35 & 6 & 0 & 2.067438 & 3.603326 & -1.515637 \\
\hline
\end{tabular}




\begin{tabular}{|c|c|c|c|c|c|}
\hline 36 & 6 & 0 & -1.768811 & 2.448770 & 1.962927 \\
\hline 37 & 6 & 0 & -0.712905 & 1.973162 & 2.924606 \\
\hline 38 & 6 & 0 & -0.844480 & 1.963029 & 4.309305 \\
\hline 39 & 6 & 0 & 0.200841 & 1.438711 & 5.077235 \\
\hline 40 & 6 & 0 & 1.343957 & 0.949426 & 4.439485 \\
\hline 41 & 6 & 0 & 1.411314 & 1.000888 & 3.049521 \\
\hline 42 & 6 & 0 & -1.483201 & -2.732862 & 2.246918 \\
\hline 43 & 6 & 0 & -0.468331 & -2.334130 & 1.165655 \\
\hline 44 & 6 & 0 & 0.957338 & -2.572040 & 1.726710 \\
\hline 45 & 6 & 0 & 1.940229 & -3.531623 & -0.332622 \\
\hline 46 & 6 & 0 & 3.028343 & -3.332724 & -1.363046 \\
\hline 47 & 6 & 0 & 3.574315 & -4.372972 & -2.112404 \\
\hline 48 & 6 & 0 & 4.539848 & -4.090367 & -3.081000 \\
\hline 49 & 6 & 0 & 4.956156 & -2.770185 & -3.273238 \\
\hline 50 & 6 & 0 & 4.389755 & -1.773549 & -2.487686 \\
\hline 51 & 6 & 0 & 3.365995 & -2.718658 & 1.484101 \\
\hline 52 & 6 & 0 & 4.250296 & -1.485569 & 1.499353 \\
\hline 53 & 6 & 0 & 5.323148 & -1.378813 & 2.388817 \\
\hline 54 & 6 & 0 & 6.171106 & -0.274002 & 2.325547 \\
\hline 55 & 6 & 0 & 5.921101 & 0.730030 & 1.383688 \\
\hline 56 & 6 & 0 & 4.831254 & 0.587626 & 0.537522 \\
\hline 57 & 1 & 0 & -5.209616 & 1.895583 & -3.408748 \\
\hline 58 & 1 & 0 & -7.200468 & 0.663186 & -2.589667 \\
\hline 59 & 1 & 0 & -8.152461 & -1.114168 & -0.946572 \\
\hline 60 & 1 & 0 & -7.726668 & -2.750055 & 0.849490 \\
\hline 61 & 1 & 0 & -6.014836 & -3.908124 & 2.426001 \\
\hline 62 & 1 & 0 & -3.652070 & -4.117072 & 3.147164 \\
\hline 63 & 1 & 0 & -2.901383 & 2.528092 & -3.125019 \\
\hline 64 & 1 & 0 & -2.111047 & 0.966722 & -3.294797 \\
\hline 65 & 1 & 0 & -0.739238 & 2.448755 & -2.059996 \\
\hline 66 & 1 & 0 & -2.132686 & 3.999622 & -0.879229 \\
\hline 67 & 1 & 0 & -3.064349 & 2.721431 & -0.091018 \\
\hline 68 & 1 & 0 & -0.019766 & 4.339302 & 1.933146 \\
\hline 69 & 1 & 0 & -1.308304 & 5.126637 & 1.010091 \\
\hline 70 & 1 & 0 & 0.308146 & 6.767364 & -0.225532 \\
\hline 71 & 1 & 0 & 2.100709 & 6.966476 & -1.961137 \\
\hline 72 & 1 & 0 & 3.237400 & 4.884969 & -2.781942 \\
\hline 73 & 1 & 0 & 2.505915 & 2.666060 & -1.830331 \\
\hline 74 & 1 & 0 & -2.363751 & 1.586290 & 1.647269 \\
\hline 75 & 1 & 0 & -2.448211 & 3.184350 & 2.408165 \\
\hline 76 & 1 & 0 & -1.734479 & 2.368010 & 4.780122 \\
\hline 77 & 1 & 0 & 0.128385 & 1.428604 & 6.160527 \\
\hline 78 & 1 & 0 & 2.177008 & 0.553699 & 5.010043 \\
\hline 79 & 1 & 0 & 2.267299 & 0.664549 & 2.474891 \\
\hline
\end{tabular}




\begin{tabular}{rrrrrr}
80 & 1 & 0 & -1.315457 & -3.760255 & 2.583494 \\
81 & 1 & 0 & -1.349143 & -2.082623 & 3.122687 \\
82 & 1 & 0 & -0.621730 & -2.963632 & 0.279639 \\
83 & 1 & 0 & 1.151952 & -1.802765 & 2.479407 \\
84 & 1 & 0 & 0.938158 & -3.547521 & 2.236284 \\
85 & 1 & 0 & 0.982358 & -3.357817 & -0.829925 \\
86 & 1 & 0 & 1.956409 & -4.567418 & 0.033782 \\
87 & 1 & 0 & 3.241981 & -5.391065 & -1.936442 \\
88 & 1 & 0 & 4.968553 & -4.892345 & -3.674315 \\
89 & 1 & 0 & 5.708921 & -2.511439 & -4.009987 \\
90 & 1 & 0 & 4.676945 & -0.731916 & -2.583014 \\
91 & 1 & 0 & 3.944991 & -3.525096 & 1.019615 \\
92 & 1 & 0 & 3.198328 & -3.040253 & 2.517521 \\
93 & 1 & 0 & 5.493182 & -2.169831 & 3.113131 \\
94 & 1 & 0 & 7.015922 & -0.194282 & 3.003131 \\
95 & 1 & 0 & 6.555262 & 1.606158 & 1.303717 \\
96 & 1 & 0 & 4.557582 & 1.338861 & -0.194191 \\
97 & 8 & 0 & 1.090468 & -0.961111 & -1.723986 \\
98 & 6 & 0 & 0.735013 & -0.161743 & -2.669054 \\
99 & 8 & 0 & 1.273972 & 0.969763 & -2.898658 \\
100 & 8 & 0 & -0.206452 & -0.465303 & -3.451888 \\
101 & 8 & 0 & -1.712349 & -2.186202 & -1.771868 \\
102 & 1 & 0 & -2.435261 & -2.674979 & -2.187924 \\
103 & 1 & 0 & -1.194883 & -1.796147 & -2.500818 \\
\hline---------------------------------------------------- & & \\
\hline 9 & 0 & 0 & 0 &
\end{tabular}

